\title{
Sensitivity comparison evaluation of computer-generated three dimensional surface topography to conventional maxillofacial radiographic imagery
}

Michael A. Hazey III

West Virginia University

Follow this and additional works at: https://researchrepository.wvu.edu/etd

\section{Recommended Citation}

Hazey, Michael A. III, "Sensitivity comparison evaluation of computer-generated three dimensional surface topography to conventional maxillofacial radiographic imagery" (2006). Graduate Theses, Dissertations, and Problem Reports. 2357.

https://researchrepository.wvu.edu/etd/2357

This Thesis is protected by copyright and/or related rights. It has been brought to you by the The Research Repository @ WVU with permission from the rights-holder(s). You are free to use this Thesis in any way that is permitted by the copyright and related rights legislation that applies to your use. For other uses you must obtain permission from the rights-holder(s) directly, unless additional rights are indicated by a Creative Commons license in the record and/ or on the work itself. This Thesis has been accepted for inclusion in WVU Graduate Theses, Dissertations, and Problem Reports collection by an authorized administrator of The Research Repository @ WVU. For more information, please contact researchrepository@mail.wvu.edu. 


\title{
SENSITIVITY COMPARISON EVALUATION OF COMPUTER- GENERATED THREE DIMENSIONAL SURFACE TOPOGRAPHY TO CONVENTIONAL MAXILLOFACIAL RADIOGRAPHIC IMAGERY
}

\author{
Michael A. Hazey III, D.D.S.
}

Thesis submitted to the School of Dentistry at West Virginia University

In partial fulfillment of the requirements

For the degree of

Master of Science

In

Orthodontics

Peter Ngan, D.M.D., Chair

Hal Reed, D.D.S., M.S.

Thomas Razmus, D.D.S., M.S.

Richard Crout, D.M.D., Ph.D.

Elizabeth Kao, D.M.D.

Department of Orthodontics

Morgantown, West Virginia

2006

Keywords: 3-D Radiography, Orthodontics, Periodontics 


\title{
ABSTRACT
}

\section{SENSITIVITY COMPARISON EVALUATION OF COMPUTER-GENERATED THREE DIMENSIONAL SURFACE TOPOGRAPHY TO CONVENTIONAL MAXILLOFACIAL RADIOGRAPHIC IMAGERY}

\author{
Michael A. Hazey III, D.D.S.; Peter Ngan, D.M.D.; Harold Reed, D.D.S.; Thomas Razmus, \\ D.D.S., M.S.; Richard Crout, D.M.D., Ph.D.; Elizabeth Kao, D.M.D.
}

Objectives: LumenIQ’s ImageIQ software enhances conventional radiographs by adding 3-D depth. This study evaluated whether a preference exists for ImageIQ format versus conventional radiographs, determined whether ImageIQ format is as sensitive as 2-D radiographs when detecting existing periodontal defects and simulated periodontal defects. Methods: 34 dental practitioners compared 12 radiographic cases with ImageIQ format. A panel of evaluators classified periodontal defects from 2-D radiographs and ImageIQ images. Simulated periodontal defects were radiographed with various radiographic variables altered, converted to ImageIQ 3-D format, and measured to evaluate the ImageIQ format compared to the 2-D control. Results: ImageIQ format showed improved image clarity and detail over the 2-D. Changes in X-ray beam exposure time, beam angulation, and bone quality had no effect on the ImageIQ format. ImageIQ format improved the accuracy of periodontal defect classification by $14.3 \%$ over 2-D. Conclusions: ImageIQ may provide a reliable diagnostic alternative to conventional two-dimensional radiographs. 


\section{DEDICATION}

To my beautiful wife, Carrie: My best friend and most important person in my life. You put up with a person that is by no means perfect but sometimes thinks that he is. I will forever be grateful for the sacrifices that you have suffered while I pursue my dreams. I promise that I will repay the favor many times over.

To my parents, Michael and Melinda: Thank you for all the support you give me. You have given me all the tools to succeed. I only hope that I have met your expectations.

To my in-laws, Jim and Sandy: Thank you for all your support throughout the years. You have made me a part of your family, and I will always feel welcome and loved in your home.

To my brothers, Matthew and Marc: Thank you for all the encouragement, I love you both very much and always look forward to the time when we can be together. I wish you both the same good fortune and successes that I have enjoyed thus far in life. 


\section{ACKNOWLEDGEMENTS}

I would like to take this opportunity to thank the following individuals who have contributed and assisted me throughout my specialty training.

Dr. Peter Ngan, for all that he brings to this program, encouraging us to learn all disciplines in this profession, for making this program fun and exciting to come to everyday.

Dr. Chris Martin, for being a wonderful clinic director and friend, easy to approach and easy to discuss issues with, you make the clinic a learning atmosphere that can not be compared.

Drs. Reed, Kao, Razmus, and Crout, for your unique insight and ideas on my project and for spending the individual time away from work to help me with my thesis.

Drs. Hornbrook, Veselicky, and Keys, for so graciously giving your precious time to be evaluators on an integral part of my thesis.

Dr. Stan Wearden, for you tireless statistical help and willingness to re-run the numbers many times.

\section{Drs. Tim Tremont, John Dempsy, Joe Bonello, Jeff Gilmore, Kerry Kirsch, Ned}

McFarland, J.B. Wilfong, and Anissa Anderson, for all the invaluable lessons and clinical knowledge that you have provided me. Thank you for sacrificing time spent away from private practice teaching me, it has proven and will continue to prove most valuable to my career.

Pam, for being someone that I could always talk to and laugh with, you are an outstanding assistant that always anticipates our needs. I will miss you and wish the best for you in the future.

Charlotte, for your sense of humor and joking personality, thank you for all your encouragement on difficult days. You have been a great friend and I will miss you.

Joyce and Tammy, for all the work that goes unappreciated, you are both invaluable to this program.

Brett, Matt, and Russ, for teaching me as much as anyone else and being true role models for us all.

Jackie, Joe, and Thomas, for being the "chosen class" and setting high standards for my class to follow and for being some of the easiest people to get along with that I have ever known. 
Meredith and Todd, for being great friends and always working together with me so very well. You have made this residency and enjoyable and unforgettable part of my life.

Glenn, Jennifer, Spencer, Lindsay, Tim, and Nikia, for making the last two years of my residency truly enjoyable. I will never forget the trips and the stories. 


\section{TABLE OF CONTENTS}

SENSITIVITY COMPARISON EVALUATION OF COMPUTER-GENERATED THREE DIMENSIONAL SURFACE TOPOGRAPHY TO CONVENTIONAL MAXILLOFACIAL

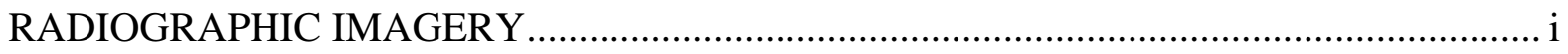

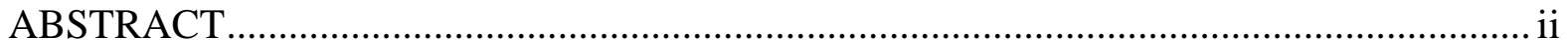

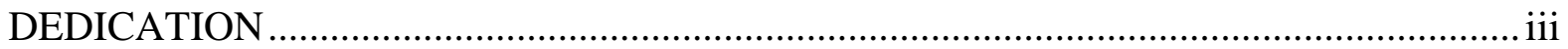

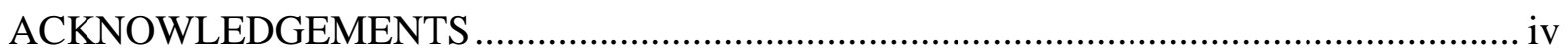

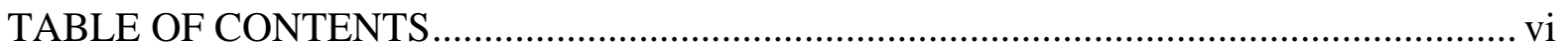

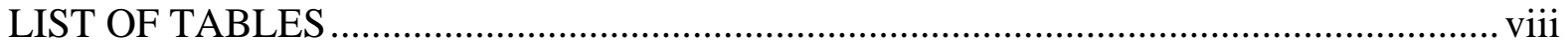

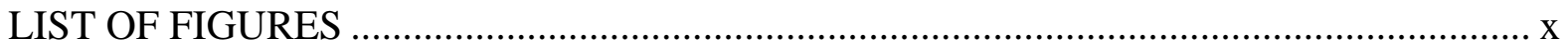

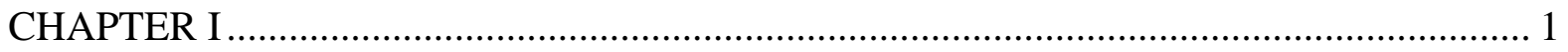

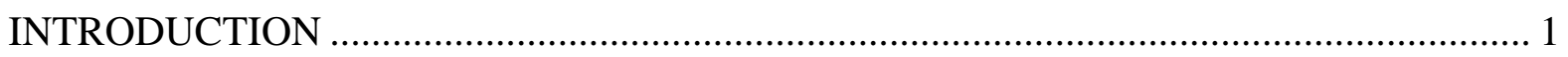

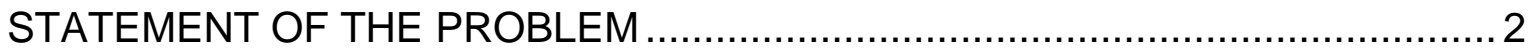

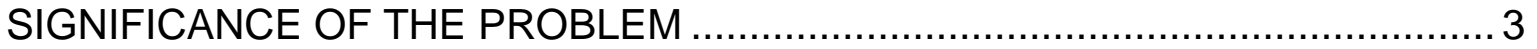

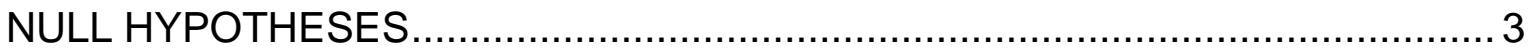

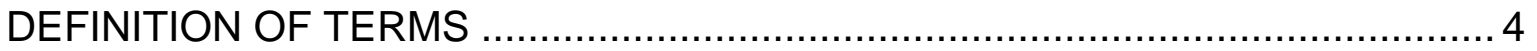

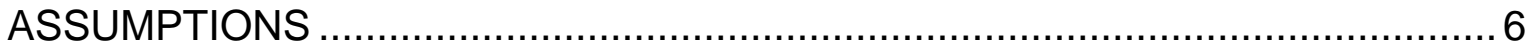

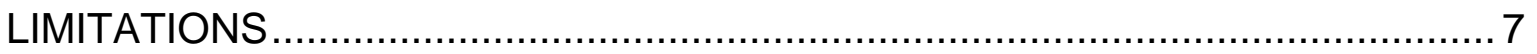

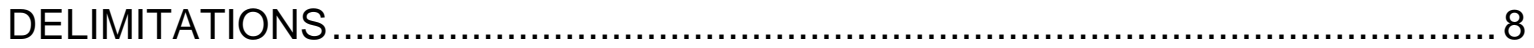

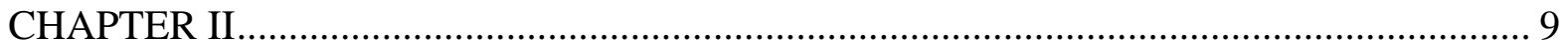

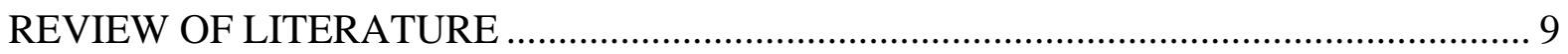

CLASSIFICATION OF PERIODONTAL DEFECTS $\ldots \ldots \ldots \ldots \ldots \ldots \ldots \ldots \ldots \ldots \ldots \ldots . \ldots$

ORTHODONTIC TREATMENT OF PERIODONTAL DEFECTS $\ldots \ldots \ldots \ldots \ldots \ldots \ldots \ldots \ldots$

RADIOGRAPHIC DETECTION OF PERIODONTAL DEFECTS $\ldots \ldots \ldots \ldots \ldots \ldots \ldots \ldots \ldots$

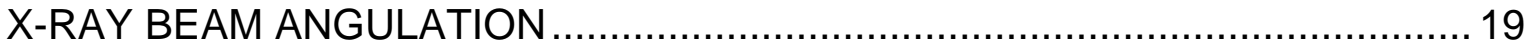

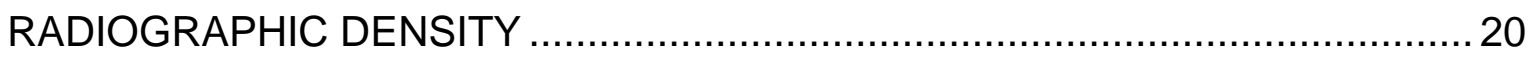

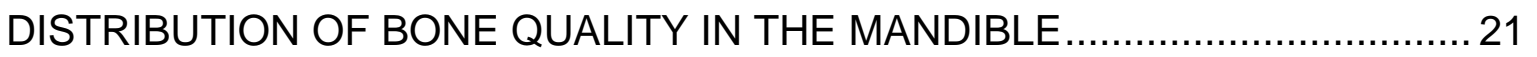

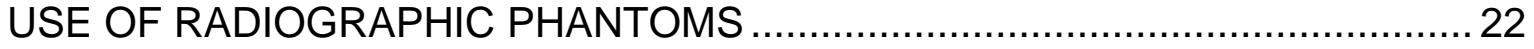

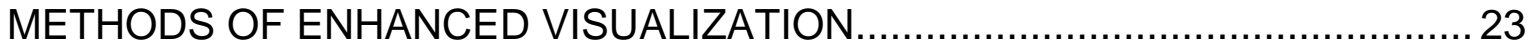

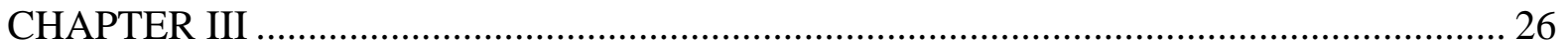

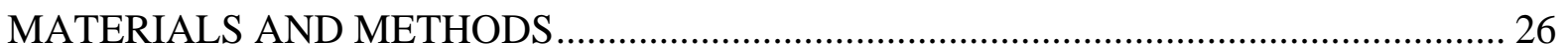

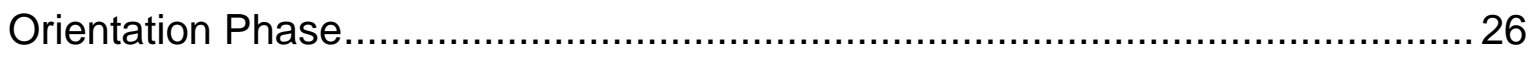

Dried Cadaver Mandible Project......................................................... 27

Edentulous Dried Cadaver Mandible Phase: Simulated Periodontal Bone Defects ...... 27

Dentate Dried Cadaver Mandible Phase ..................................................................... 39

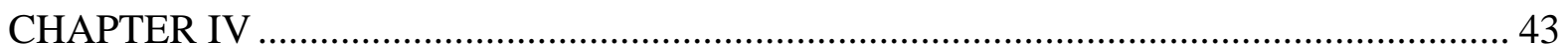

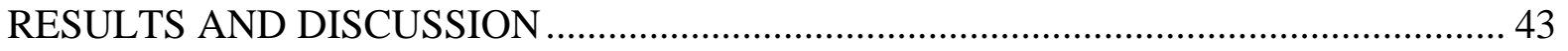

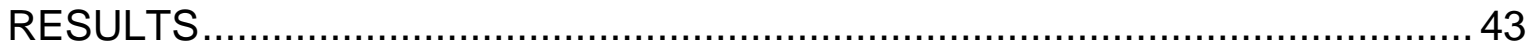

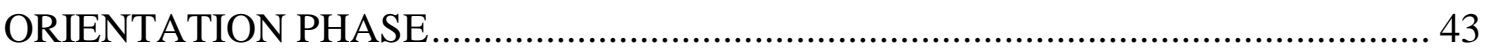

EDENTULOUS DRIED CADAVER MANDIBLE PHASE ...................................... 47

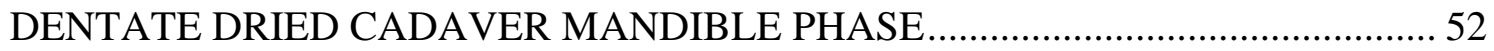

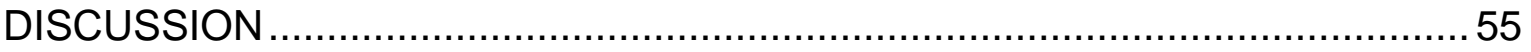

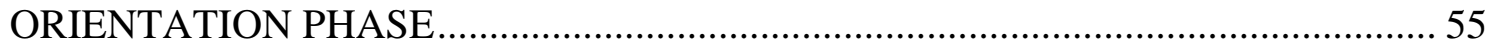

EDENTULOUS DRIED CADAVER MANDIBLE PHASE ...................................... 57 


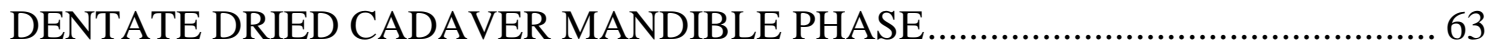

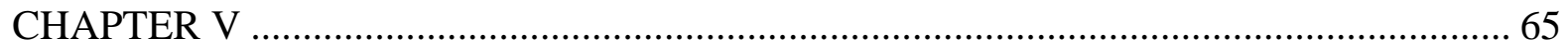

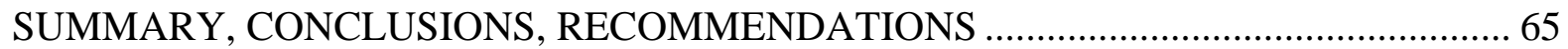

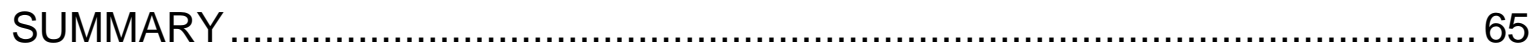

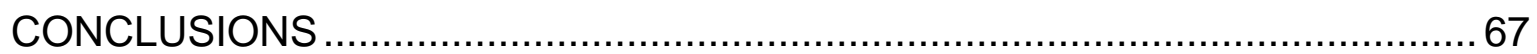

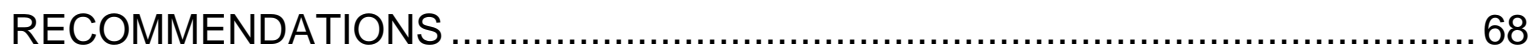

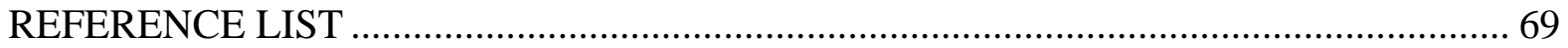

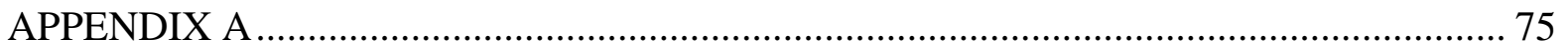

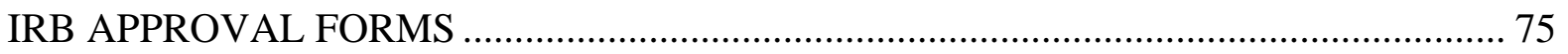

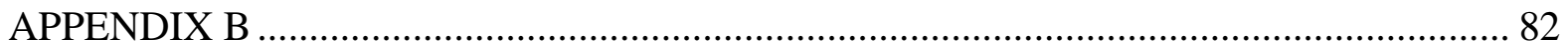

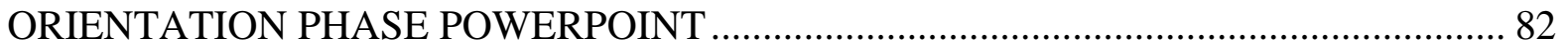

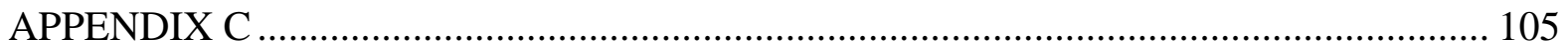

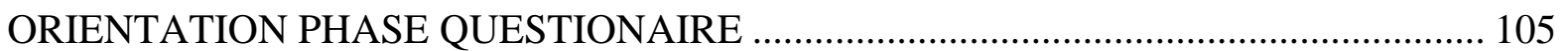

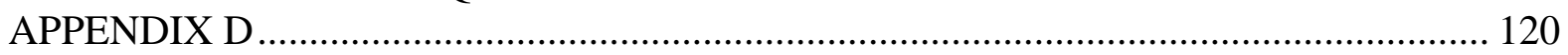

STATISTICAL ANALYSIS - ORIENTATION PHASE ............................................... 120

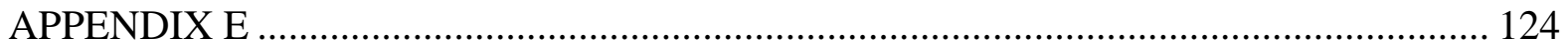

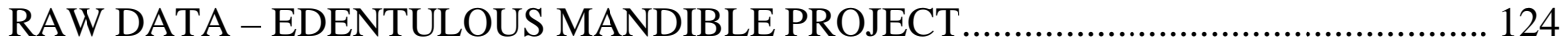

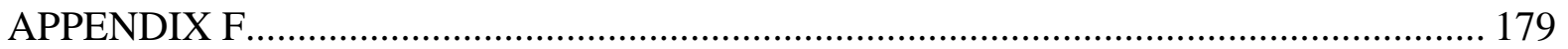

STATISTICAL ANALYSIS - EDENTULOUS MANDIBLE PROJECT ........................ 179

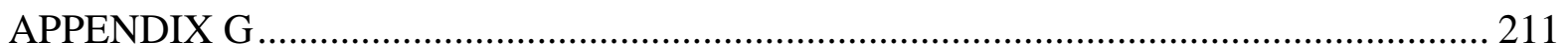

STATISTICAL ANALYSIS - DENTATE MANDIBLE PROJECT ….......................... 211

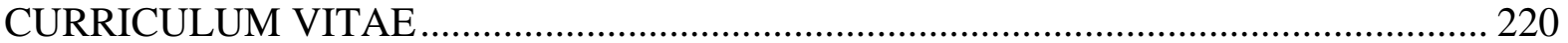




\section{LIST OF TABLES}

Table 1. Comparison of conventional 2-D x-ray and 3-D topographical map based on clarity.

Table 2. Comparison of conventional 2-D x-ray and 3-D topographical map based on detail

Table 3. Statistical significance of the preference for either image type based on quality, confidence, and fatigue.

Table 4. ANOVA comparison between diameter, width, and length measurements made using the conventional x-ray and the computer generated topographical rendering with 12 impulses 90 degrees based on defect location: Anterior, Posterior

Table 5. ANOVA comparison between diameter, width, and length measurements made using the conventional $x$-ray and the computer generated topographical rendering with 12 impulses, 90 degrees based on defect size: $1 \mathrm{~mm}, 2 \mathrm{~mm}, 4 \mathrm{~mm}$.....

Table 6. ANOVA comparison between diameter measurements made using the conventional $\mathrm{X}$-ray and the computer generated topographical rendering with 12 impulses, +10 degrees based on defect location: Anterior, Posterior.

Table 7. ANOVA comparison between diameter, width, and length measurements made using the conventional $x$-ray and the computer generated topographical rendering with 12 impulses, +10 degrees based on defect size: $1 \mathrm{~mm}, 2 \mathrm{~mm}, 4 \mathrm{~mm}$.

Table 8. ANOVA comparison between diameter, width, and length measurements made using the conventional $x$-ray and the computer generated topographical rendering with 12 impulses, +20 degrees based on defect location: Anterior, Posterior .....

Table 9. ANOVA comparison between diameter, width, and length measurements made using the conventional $x$-ray and the computer generated topographical rendering with 12 impulses, +20 degrees based on defect size: $1 \mathrm{~mm}, 2 \mathrm{~mm}, 4 \mathrm{~mm}$.

Table 10. ANOVA comparison between diameter, width, and length measurements made using the conventional $\mathrm{x}$-ray and the computer generated topographical rendering with 8 impulses, 90 degrees based on defect location: Anterior, Posterior

Table 11. ANOVA comparison between diameter, width, and length measurements made using the conventional $\mathrm{x}$-ray and the computer generated topographical rendering with 8 impulses, 90 degrees based on defect size: $1 \mathrm{~mm}, 2 \mathrm{~mm}, 4 \mathrm{~mm}$..... 
Table 12. ANOVA comparison between diameter, width, and length measurements made using the conventional $\mathrm{x}$-ray and the computer generated topographical rendering with 18 impulses, 90 degrees based on defect location: Anterior, Posterior

Table 13. ANOVA comparison between diameter, width, and length measurements made using the conventional $\mathrm{x}$-ray and the computer generated topographical rendering with 18 impulses, 90 degrees based on defect size: $1 \mathrm{~mm}, 2 \mathrm{~mm}, 4 \mathrm{~mm}$

Table 14. Comparison between groups for significant agreement ..................................... 53

Table 15. Comparison of Standard X-ray Value to Intrasurgical Value.................................. 54

Table 16. Comparison of Topographical Map Value to Intrasurgical Value ......................... 54

Table 17. Combined results for the three evaluators in Comparison to Intrasurgical Value..54 


\section{LIST OF FIGURES}

Figure 1. Types of vertical periodontal defects: A) 3-walled, B) 2-walled, C) 1-walled ....... 10

Figure 2. Protection rope wax on inferior border ...................................................... 28

Figure 3. Plaster model base mold modified by removal of posterior portion ..................... 28

Figure 4. Edentulous dried cadaver mandible set in plaster in base mold .......................... 29

Figure 5. Edentulous dried cadaver mandible in plaster base with sides trimmed ............... 30

Figure 6. 1/4" central hole and 1/8" slit in plaster base ............................................... 30

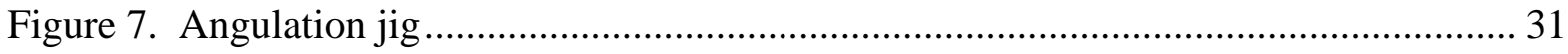

Figure 8. Reference marks on angulation jig placed perpendicular to the pointer ............... 32

Figure 9. Edentulous cadaver mandible secured on angulation jig with base parallel to

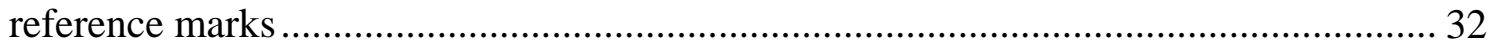

Figure 10. Custom drill press secured on tabletop......................................................... 33

Figure 11. Edentulous dried cadaver mandible on dental surveyor to check for flat surfaces

Figure 12. Simulated periodontal defect arrangement (note: actual arrangement was

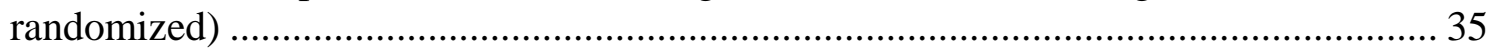

Figure 13. Edentulous dried cadaver mandible on custom drill press ............................... 36 


\section{CHAPTER I}

\section{INTRODUCTION}

Orthodontists are routinely involved in the treatment of periodontal bony defects. Molar uprighting and forced eruption are examples of procedures undertaken by orthodontists to treat periodontal defects. In addition, the presence of a defect may alter an orthodontic treatment plan. For example, a decision has to be made on whether to move teeth that are associated with a defect or whether to move teeth into an area of bone containing a defect. Therefore, the detection and diagnosis of such defects is important in prescribing the proper orthodontic treatment. An important part of this detection is the radiograph. Previous studies have shown the inability of traditional two-dimensional radiographs to adequately describe a three-dimensional periodontal defect when compared to the gold standard of intrasurgical measurement. ${ }^{1}$ Studies have statistically shown that traditional radiographs can significantly underestimate the amount of interproximal bone loss that is actually present in up to $71 \%$ of cases. $^{2}$

It has been stated that with respect to the quality of images produced, the standardized x-ray film system should be the standard with which other systems are compared if they are intended to replace established radiographic techniques. ${ }^{3}$ A number of technological advances in radiography have attempted to improve upon the standard of traditional x-ray imaging. Many of these advances have tried to increase the quality of radiographs. A new software platform, LumenIQ’s ImageIQ, enhances conventional digitized radiography by using computer generated topographical mapping to add depth to a two-dimensional film. However, the ability of this system to improve upon conventional 2-D dental radiographs has 
not been explored. Furthermore, the efficacy of using LumenIQ to increase the radiographic discriminability of periodontal defects is not known.

The present proposal was therefore undertaken to first, investigate the interest and perceived usefulness of this new software in dental radiography. A panel of dental practitioners evaluated conventional 2-D and LumenIQ's 3-D topographical rendering to assess the applicability of this technology to dentistry. Second, the study will attempt to investigate the discriminability between LumenIQ’s computer generated 3-D topographical rendering and conventional dental radiology in terms of periodontal defect detection and classification. Dentate dried cadaver mandibles with existing periodontal defects were radiographed, rendered with ImageIQ, and evaluated. Simulated periodontal defects of specific dimensions were made in edentulous dried cadaver mandibles and radiographed, rendered with ImageIQ, and evaluated. The evaluation attempted to determine if ImageIQ's discriminability was greater than that of conventional digitized radiographs. The exposure times and beam angulations were varied to show the effect on the rendered images. The difference between renderings made of simulated defects in higher density/quality anterior mandibular bone and those made in lower density/quality posterior mandibular bone was evaluated as well. Finally, the study explored any differences in ImageIQ’s ability to detect simulated defects of different sizes.

\section{STATEMENT OF THE PROBLEM}

Does significant interest in the improvement of diagnostic radiography through 3-D computer enhancements exist? Does a three-dimensional topographical rendering have better image detail, clarity, and overall quality compared to a conventional 2-D radiograph? Does a dental practitioner perceive a higher level of confidence and lower level of fatigue when 
viewing a three-dimensional topographical rendering compared to a conventional 2-D x-ray? Does a three-dimensional topographical rendering increase the ability to classify periodontal defects when compared to conventional 2-D radiography? Does a three-dimensional topographical rendering have better ability to accurately image a periodontal defect of known dimension when compared to conventional 2-D radiography? Does variation in exposure time and beam angulation affect the quality of the rendered radiograph? Does the difference in bone density/quality between the anterior and posterior portions of the mandible affect the quality of the enhanced radiograph? Does the difference in defect size affect the ability of the rendered radiograph to detect a periodontal defect?

\section{SIGNIFICANCE OF THE PROBLEM}

Previous studies have shown the inability of traditional 2-D radiographs to adequately describe a 3-D periodontal defect when compared to intrasurgical measurement. ${ }^{1}$ The result of this study will provide information on the discriminability of LumenIQ's ImageIQ rendered radiographs compared to traditional digitized radiographs and therefore their use as a diagnostic tool for periodontal defects. In addition, the data will provide information on the effect of variation in exposure time, beam angulation, mandibular bone density/quality, and defect size on the quality of the 3-D topographically rendered images.

\section{NULL HYPOTHESES}

1. No significant difference exists in the levels of image clarity, image detail, overall image quality, and observer confidence and fatigue levels between LumenIQ’s ImageIQ 3-D topographically rendered radiographs and traditional digitized 2-D radiographs. 
2. No significant difference exists between conventional 2-D radiographs and ImageIQ’s 3-D topographical renderings when exposure time is varied.

3. No significant difference exists between conventional 2-D radiographs and ImageIQ’s 3-D topographical renderings when beam angulation is varied.

4. No significant difference exists between conventional 2-D radiographs and ImageIQ’s 3-D topographical renderings when imaged from higher density/quality anterior mandibular bone and lower density/quality posterior mandibular bone.

5. No significant difference exists between conventional 2-D radiographs and ImageIQ’s 3-D topographical renderings when defect widths of $1 \mathrm{~mm}, 2 \mathrm{~mm}$, and $4 \mathrm{~mm}$ are used.

6. No significant difference exists between conventional 2-D radiographs and ImageIQ’s 3-D topographical renderings in the determination of existing periodontal defect classification.

7. No significant difference exists in the discriminability of periodontal defects between LumenIQ’s ImageIQ 3-D topographically rendered radiographs and traditional digitized radiographs.

\section{DEFINITION OF TERMS}

1. Conventional radiography - the use of x-ray film and an x-ray machine to produce a radiograph of a specified hard tissue structure.

2. Digital Radiography - the use of an x-ray sensitive digital sensor and an x-ray machine to produce a digitized radiographic image of a specified hard tissue structure. 
3. Digitized Radiograph - The type of radiograph that is produced when a film-based radiograph is scanned using a digital scanner.

4. Exposure Time - the amount of time measured in seconds or fractions of seconds that an object is exposed to an x-ray beam. A main determinant of radiographic density.

5. Gray Scale - the different shades of gray between the extremes of black and white in a radiographic image. This is also referred to as image contrast.

6. Periodontal Defect - an area of bone loss in supporting alveolar bone.

7. Radiographic Density - the overall darkness of a radiograph. Determined by the multiplication of milliamperage and exposure time in seconds.

8. Bone Quality - A description of bone structure which includes the relative amounts and density of cortical and trabecular bone.

9. Soft Tissue Phantom - a material that accurately simulates the density and x-ray scattering properties of human soft tissue in experiments involving radiography.

10. Subtraction Radiography - the use of computer software to analyze two or more radiographs and produce a composite image showing only those areas that have undergone some degree of change.

11. Tomography - the movement of the x-ray producing tubehead and x-ray film in parallel planes but opposite in directions to produce an image of a hard tissue specimen in sections of a specific width.

12. Cone-Beam Computed Tomography - the rotation of the x-ray producing tubehead around the patient producing 365 slices as axial projection data that is reconstructed into a 3-D image by computer. 
13. Computer-generated 3-D topographical rendering - the type of image produced by LumenIQ's ImageIQ software which converts the gray scale in a conventional radiograph to vertical heights on an $\mathrm{X}-\mathrm{Y}-\mathrm{Z}$ axis.

14. Z-axis - The third dimensional direction represented by vertical height on an X-Y-Zaxis.

15. X-ray Beam Angulation - the angle of application of an X-ray beam upon an object measured in both the horizontal and vertical direction.

16. 2-D - Two Dimensional

17. 3-D - Three Dimensional

18. Radiographic Image Clarity - Related to radiographic image sharpness. The ability to define the edge of an object.

19. Radiographic Image Detail - A qualitative measure of how much information an evaluator gets from an image.

20. Overall Radiographic Image Quality - Characteristic of radiographs involving contrast, density, sharpness, and object positioning.

21. Fatigue Level - How long an evaluator had to view an image when evaluating the image.

22. Confidence Level - How sure the evaluator is of his or her decision when evaluating an image.

\section{ASSUMPTIONS}

1. Dental practitioners are continually looking to technology to improve clinical diagnostic quality. 
2. Conventional radiography is the standard periodontal defect detection technology at this time.

3. Conventional radiography has limitations in the detection of periodontal defects.

4. The human eye has limits to its ability to detect the 256 gray scales present in conventional radiographs.

5. LumenIQ’s ImageIQ software increases the number of gray scales that can be seen by the human eye by assigning a height to gray scales on the Z-axis.

6. The human eye can more easily see differences in vertical height than differences in gray scales.

\section{LIMITATIONS}

1. LumenIQ’s ImageIQ software produces a new type of image, which a panel of investigators will not be familiar with viewing.

2. The subjectivity of individual evaluators may influence the continuity of the evaluation. Standardization of the evaluators will limit this effect.

3. The ImageIQ software has numerous image enhancing features including various filters, magnification, and histogramatic effects. No default or ideal settings are known at this time. The principal investigator will choose the settings of these features that produce the most useful image. It is possible that different settings may alter the image quality of individual radiographs.

4. Dried cadaver mandibles do not fully substitute for living, biologic bone. The characteristics of dried bone are different than that of living bone.

5. The periodontal defects will be made in a symmetrical manner. Actual defects may take irregular shapes. 


\section{DELIMITATIONS}

1. The study will be limited to the dental practitioner's perception of LumenIQ's usefulness in dental radiography. Image detail, clarity, quality, as well as confidence and fatigue levels will be evaluated.

2. The study will be limited to the ability of the software enhancements to detect periodontal defects and simulated periodontal defects.

3. The study will only compare enhanced radiographs to digitized conventional radiographs.

4. Existing periodontal defects in dentate dried cadaver mandibles will be evaluated.

5. Simulated periodontal defects will be placed in the edentulous anterior and posterior regions of the dried cadaver mandibles.

6. The variables of the study will be limited to exposure time, beam angulation, differing bone density/quality between anterior and posterior mandibular regions, and different defect size.

7. One researcher performed all of the radiographic procedures.

8. One researcher performed all of the software renderings.

9. One researcher performed all of the radiographic and rendering defect measurements. 


\section{CHAPTER II \\ REVIEW OF LITERATURE}

\section{CLASSIFICATION OF PERIODONTAL DEFECTS}

Changes that occur in alveolar bone are significant because the destruction of this bone is ultimately responsible for tooth loss. A periodontal defect is defined as an osseous defect in the supporting alveolar bone. ${ }^{4}$ Periodontal defects can take on many forms. A horizontal defect, the result of what is often referred to as horizontal bone loss, is the most common pattern of bone loss. The bone level is reduced in a more or less even pattern with the bony margin remaining perpendicular to the tooth surface. The bone level is also relatively parallel to the cemento-enamel junctions of adjacent teeth. The vertical or angular defect is another type of periodontal defect. This bone loss pattern occurs in an oblique direction and leaves a hollowed-out trough in bone adjacent to the tooth root. These defects can also occur on facial or lingual/palatal surfaces of bone. Goldman and Cohen classified vertical defects based on the number of bony walls intact. By this classification, it is possible to have a one, two or three-walled defect. ${ }^{5}$ Three-walled defects are often referred to as infrabony defects. Figure 1 from Carranza shows examples of the types of vertical defects. ${ }^{4}$ 

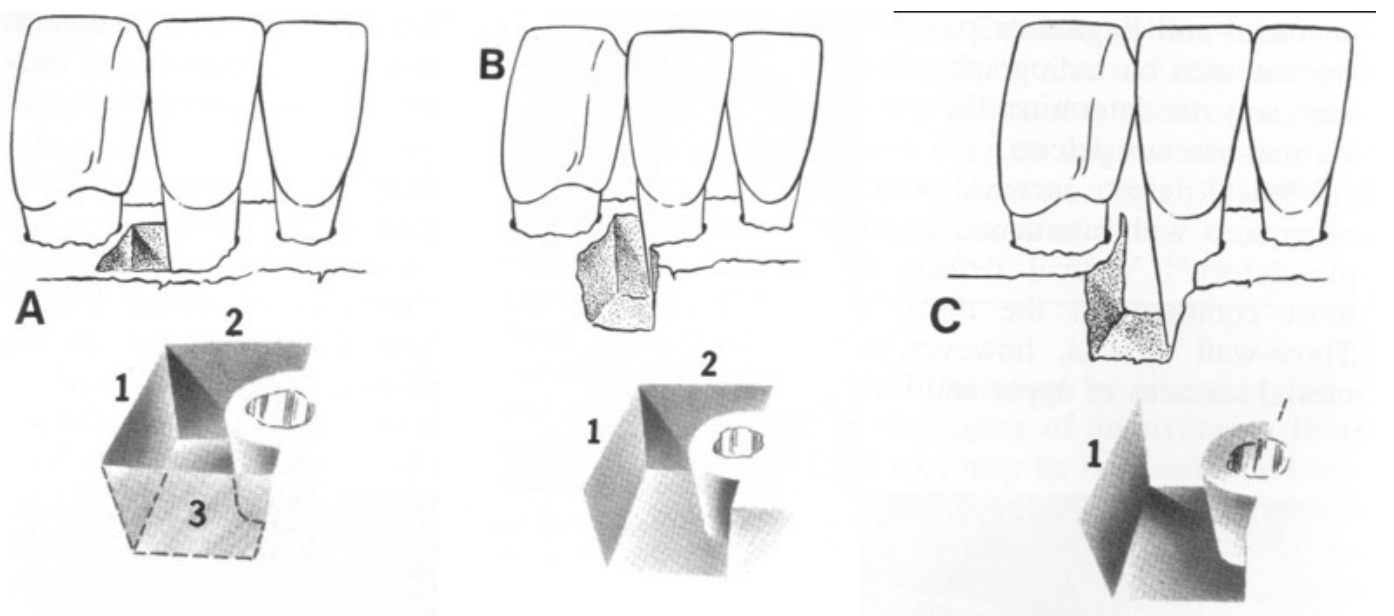

Figure 1. Types of vertical periodontal defects: A) 3-walled, B) 2-walled, C) 1-walled Other types of vertical periodontal defects are difficult to classify by the previous system. These types include bulbous bone contours, reverse architecture, ledges, and furcation involvements. Bulbous bone contours are bony enlargements caused by exostoses, adaptation to function, or bony buttressing. More common in the maxilla than mandible, bulbous bone contours represent a deposition of bone rather than a resorption of bone. ${ }^{4}$ Reverse bony architecture is a defect occurring when the facial and lingual plates of interdental bone are lost without the loss of radicular bone. Ledges refer to plateau-like bone margins that occur due to resorption of thickened bony plates. ${ }^{4}$ Furcation involvements are defects that arise when bone loss occurs in the bi- and tri-furcations of multi-rooted teeth.

Vertical defects are most commonly encountered in orthodontics. These types of defects are encountered with mesially tilted posterior teeth and cases of localized periodontal disease. The diagnosis of vertical periodontal defects is important for the orthodontist as he or she attempts to form a treatment plan to either avoid or treat the periodontal defect through orthodontics. Furthermore, the orthodontist would like to have a visual image of the 
topography and dimensions of the defect to properly prescribe treatment. The radiograph is commonly used to provide this image.

The dimensions of a vertical defect are considerably more difficult to determine radiographically than horizontal defects and often require careful probing and/or surgical exposure for confirmation. The shortcomings of traditional radiography in imaging vertical defects often lies in the presence of thick buccal and lingual cortical plates that obscure the defect. This thick cortical plate often does not allow an accurate radiographic image of the defect as the plate decreases the number of x-rays that are able to irradiate the defect and produce an image.

Chronic inflammation is the most common cause of bone destruction in periodontal disease. The movement of inflammation from the marginal gingival into the periodontal tissues indicates the transition from gingivitis, or gum disease, to periodontitis. This transition also marks a change in the composition of plaque bacteria. Advanced periodontal disease shows an increase in motile bacteria and spirochetes, and a decrease in coccoid rods and straight rods. ${ }^{6}$ In addition, the cellular composition of the periodontal connective tissue changes as plasma cells and blast cells replace fibroblasts and lymphocytes. As the lesion progresses further, destructive polymorphonuclear leukocytes and osteoclasts appear as the resorption of the alveolar crest of bone begins. The periodontal tissues are destroyed as the body attempts to fight off the organisms present in plaque.

Another cause of periodontal defects is trauma from occlusion. Trauma from occlusion can cause bone destruction in the absence or presence of inflammation. In the absence of inflammation, bony changes vary from the increased compression or tension of the periodontal ligament and increased osteoclastic resorption of alveolar bone to necrosis of 
the periodontal ligament and supporting bone.? Repeated trauma from occlusion results in a funnel-shaped or angular/vertical periodontal defect as the crestal portion of the periodontal ligament is widened and the adjacent alveolar bone is resorbed. ${ }^{8}$ When combined with inflammation, trauma from occlusion accelerates the bone destruction further and often results in bizarre bone loss patterns. ${ }^{8}$

Systemic disorders can also be responsible for bone destruction. Examples of these types of systemic disorders include hyperparathyroidism, leukemia, and Hand-SchullerChristian disease. ${ }^{4}$ These mechanisms may be unrelated to any existing periodontal problem.

The rate of periodontal bone loss is an important parameter in successful treatment and prevention of further bone loss. Loe and associates described the rate of periodontal bone loss in a study of subjects lacking oral hygiene or dental care. They found that facial surfaces lost $0.2 \mathrm{~mm}$ of bone per year on average, and proximal surfaces lost $0.3 \mathrm{~mm}$ of bone per year on average. ${ }^{9}$ It is important to note that these rates of bone loss may not represent the effect of advanced periodontal disease or rapidly progressive periodontal diseases. The rate of periodontal bone loss in these cases is often more rapid. ${ }^{4}$

\section{ORTHODONTIC TREATMENT OF PERIODONTAL DEFECTS}

The mesial tilting of posterior teeth as a result of loss of arch integrity due to extractions, extensive caries, or ectopic tooth eruption is a common problem in adult orthodontic patients. The tilted position of these posterior teeth impairs the patient's ability to maintain good oral hygiene and can lead to occlusal trauma as forces are no longer directed down the long axis of the tooth. This compromised tooth position also makes adequate restoration of the teeth difficult and sometimes impossible. These factors, along 
with the presence of dental plaque bacteria, can promote the formation of intraosseous periodontal defects. ${ }^{10}$

Orthodontic treatment is a viable option for a means of attaining a more favorable osseous contour in some cases with periodontal defects. This means of treatment is especially advocated in a one-walled defect in which the predictability of regenerative periodontal therapy is very low. ${ }^{11}$ Various orthodontic movements such as intrusion, extrusion, moving a tooth toward the defect, and moving the tooth away from the defect can modify the osseous contour. ${ }^{12,13,14}$ Molar uprighting, besides an obvious improvement of the prosthetic treatment plan, frequently reduces or eliminates the periodontal defect without any need for regenerative periodontal therapy..$^{15,16,17}$

Cirelli, et al. concluded that orthodontic movement did not interfere with the healing process of one-walled intraosseous periodontal defects specifically for the following parameters: connective tissue attachment levels, apical extent of epithelial migration, and new cementum formation. ${ }^{10}$ Polson, et al. ${ }^{13}$ and Lindskog-Stokland, et al. ${ }^{18}$ found similar results in their investigation of tooth movement towards periodontal defects. Ericsson, et al. ${ }^{19}$ and Garaci, et al. ${ }^{14}$ reported an increase in the connective tissue attachment levels after performing mesial inclination and bodily movement of teeth toward such defects. Therefore, the conclusion can be made that orthodontic tooth movement in certain periodontal conditions does not decrease the periodontal healing characteristics and in some cases may enhance those healing characteristics.

In other cases, orthodontic treatment is not advocated for correcting periodontal defects. One such case is active periodontal destruction. If the inflammation from periodontal disease is not arrested prior to orthodontic tooth movement, the situation will 
worsen. The reason for this statement lies in the fact that orthodontic tooth movement is itself an inflammatory process. Orthodontic inflammation in addition to already present periodontal inflammation can result in a more rapid periodontal destruction. ${ }^{20}$

Another scenario in which orthodontics is not advocated in the treatment of periodontal defects is the presence of a three-walled vertical defect. A three-walled vertical defect is best treated using an osseous regenerative procedure. ${ }^{21}$ The rationale behind this treatment plan is the fact that a three-walled defect has enough bony support to hold a bone graft is place. In addition, the higher the number of bony walls present, the greater the supply of cells for regeneration. ${ }^{15}$ This situation would not be true for a one- or two-walled defect, which would not as easily hold a bone graft and would have less surface area from which to provide cells for regeneration.

At any rate, the possibility of successful orthodontic treatment of periodontal defects increases the need for more accurate detection and diagnostic procedures.

\section{RADIOGRAPHIC DETECTION OF PERIODONTAL DEFECTS}

The detection and accurate assessment of the location, extent, and configuration of the periodontal defect is important for the determination of the tooth prognosis, treatment plan, and the maintenance procedures. ${ }^{22}$ When it comes to the detection and diagnosis of periodontal defects, many methods can be used. Manual probing to discern the borders and dimensions of the defect is the most acceptable clinical assessment of periodontal inflammation. ${ }^{4}$ Radiography is used in an attempt to supplement the manual probing and provide a picture of the defect. The gold standard for in-depth description of a defect's dimensions is intrasurgical measurement. ${ }^{2,23,24,25,26,27}$ Only by this method can the clinician see the topography and extent of the defect in its entirety. Obviously, the intrasurgical 
measurement procedure is the most invasive, costly, and time-consuming. In addition, manual probing is very technique sensitive and is difficult to standardize between clinicians. Therefore, increasing emphasis is placed on radiography for the detection and description of periodontal defects. However, the effectiveness of radiography for this purpose has been less than ideal.

CONVENTIONAL RADIOGRAPHY. Previous studies have shown the inability of traditional 2-D radiographs to adequately describe a 3-D periodontal defect when compared to intrasurgical measurement. ${ }^{1}$ Studies have statistically shown that traditional radiographs

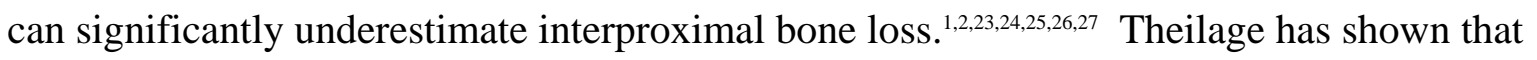
this underestimation occurred in up to $71 \%$ of the specimens that were investigated. ${ }^{2}$ Others have determined the accuracy of different types of radiographs in detecting periodontal defects. Pepelassi, et al. found that conventional periapical radiographs detect only 61.85\% of defects and panoramic radiographs detect only 20.99\%. ${ }^{28}$ Furthermore, the study found that periapical radiographs were better at describing the depth and mesiodistal width of the defect than describing the buccolingual width and number of walls the defect contained. The study showed that the smaller the number of walls surrounding the defect, the lower the detectability of the periapical radiograph, i.e., three-walled were easier than two walled which were easier than one-walled defects, unless the depth and/or the buccolingual width were very small. Furthermore, one-walled defects of small depth and large buccolingual width were even difficult to detect radiographically. ${ }^{28}$ These detection limitations are even more unfortunate as one recalls that orthodontic treatment of one-walled defects was advocated over periodontal regenerative treatment. Unfortunately, no sure method exists of radiographically determining the type of defect present. 
The overall shortcoming of conventional radiographs in accurately detecting a periodontal defect may be partly attributed to the initial alveolar bone resorption occurring predominantly at the crestal region. This loss of bone is therefore masked by the adjacent cortical plates that initially remain intact. ${ }^{29}$ In a related study, Wengraf produced lesions with round burs in dried specimens of bone and found that unless the cortical bone was removed, a lesion could not be demonstrated radiographically. ${ }^{30}$ This creates an obvious diagnostic problem in the evaluation of periodontal defects by a radiograph.

DIGITAL RADIOGRAPHY. With the advent of digital radiography, new attempts were made to improve imaging of periodontal defects through various computer enhancements. Early investigators digitized traditional film radiographs with scanners and attempted to adjust certain parameters to produce a higher quality image. However, studies have shown that the manipulation of such digital effects as gray scale differential and magnification failed to result in more valid or reproducible measurements of interproximal bone loss when compared to the unmanipulated digital radiographs. Furthermore, it was found that the digitized, enhanced radiographs, in some cases, tended to overestimate the amount of bone loss as assessed by intrasurgical methods. ${ }^{31}$

Perhaps the reason for this conclusion lies in the fact that a fundamental limitation exists with this method of improvement. The human eye has a finite ability to discriminate gray-scale levels. The gray scale is the number of shades of gray occurring between the extremes of black and white. The human visual system mutes gray scale image perception to approximately 32 distinct intensity values. ${ }^{32}$ Therefore, improvements in technology to increase the definition of $x$-rays by increasing the gray scales will not have any significant effect beyond the eye's maximum ability to perceive differences in these levels. 
As direct digital radiographic technology became more widespread, clinicians compared the validity of this type of image with conventional radiography for detecting periodontal bone loss. Chang, et al. found that measurements of average alveolar bone levels differed significantly between conventional and direct digital radiography. They concluded that the digital images tended to reveal a higher number of sites with early to moderate bone loss than did the conventional images. ${ }^{33}$ These findings showed a greater tendency for false positive diagnosis of a periodontal defect. Therefore, direct digital radiographs are not an equivalent substitute for conventional radiographs for evaluating alveolar bone levels.

SUBTRACTION RADIOGRAPHY. Subtraction radiography has been used with widespread success in the field of medicine to image bony changes. The technique consists of taking sequential radiographs over a period of time. A computer then combines the films, and all structures that remained unchanged are removed from the final image, which now only depicts those structures that have changed. As the "structural noise" of the image is removed, an increase in the visibility of the changing lesion should result. ${ }^{34}$ In dentistry, this technique has been shown by Holthuis, et al. to improve the ability to detect the progression or remission of three-walled periodontal defects when compared to traditional radiography. ${ }^{34}$ Grondahl, et al. reported that digital subtraction radiography could be used to analyze experimentally produced lesions in dried skulls more accurately than traditional dental radiographs. ${ }^{35}$ Ortman, et al. found that a 5\% change in bone mineral per unit area could be detected with subtraction radiography. ${ }^{36}$ Therefore, subtraction radiography was found to have an advantage over traditional radiography. However, subtraction radiography relies upon a change in the defect and is not practical for imaging the defect at any one point in 
time. Subtraction radiography also places great importance on accurate patient repositioning for each successive radiograph. This task often proves difficult to accomplish.

TOMOGRAPHY. Tomography has also been considered as a possible method of improving upon traditional radiographic depiction of periodontal defects. Tomography is used to describe all types of body-sectioning techniques using radiography. ${ }^{37}$ Tomography uses movement of the x-ray tubehead and film in parallel planes but opposite in direction. The basic concept of tomography is to focus on the plane of bone in the fulcrum of movement between the x-ray film and the source. The planes not within this fulcrum are blurred. $^{38}$ In dentistry, tomography has been used for the examination of the temporomandibular joint and in the placement of implants. Stalker, et al. compared tomography to traditional radiographs in the detection of periodontal defects. The researchers found that tomography was not a more reliable method of evaluating defects that were prepared in dog jaws. ${ }^{39}$ As with conventional radiography, tomography failed to detect periodontal defects that were made entirely within cancellous bone and shielded by the cortical plates. Furthermore, the amount of diagnostic information obtained from the tomogram was not sufficient to justify its costly use and increased radiation dose to the patient. ${ }^{36}$ The radiation dose is generally greater as tomography uses a longer exposure time and higher milliamperage than conventional radiography. ${ }^{40,41}$

CONE-BEAM COMPUTED TOMOGRAPHY. The recent development and application of cone beam computed tomography (NewTom 9000, NewTom AG, Marburg, Germany; PSR 9000, Asahi Roentgen Ind. Co. Ltd., Kyoto, Japan; i-CAT, Imaging Sciences International, Hatfield, PA.) to dental imaging techniques has also improved the clinician's ability to image 3-D structures. This technology has been successfully applied to the clinical 
assessment of alveolar bone grafting ${ }^{21}$ and to bone density evaluation ${ }^{42}$ and positioning for dental implants. ${ }^{43}$

In general, dental cone beam computed tomography systems work like a conventional panoramic machine. The x-ray unit and image intensifier rotate around the object as the exposure is being completed. A scan will generally produce 365 slices as axial projection data. ${ }^{44}$ The data is then transferred to the workstation consisting of a computer with imaging software. From this projection data, the workstation can reconstruct any section in 3-D.

The advantages of cone beam computed tomography are many. Perhaps the most important is the ability to produce three-dimensional images. In addition, these images can be produced with a lower radiation dose and higher resolution in any directional axis when compared with conventional computed tomography. ${ }^{44}$ A recent study shows that the radiation dose, under optimum exposure conditions, is less than one-fifteenth that of spiral CT. ${ }^{45}$ Further study on the application of cone beam computed tomography to dentistry and the diagnosis of periodontal defects is needed.

\section{X-RAY BEAM ANGULATION}

The projection geometry or angulation of the x-ray beam may influence the validity of the image interpretation. Previous studies have shown statistically significant changes in such parameters as the measurement of periodontal ligament space width ${ }^{46}$ and alveolar bone levels ${ }^{3,47}$ when beam angulations are changed from perpendicular. Eickholz, et al. examined the influence of projection geometry on radiographic evaluation of interproximal bone loss. ${ }^{3}$ The study found that changes in the projection geometry between consecutively obtained radiographs showed different two-dimensional images of the same three-dimensional structure. Furthermore, the study showed that changing the horizontal angulation increased 
the risk of projecting an adjacent tooth root over the periodontal defect in question. The study stated that changing the vertical angulation led to a double silhouette of the alveolar crest. The investigators therefore concluded that vertical and particularly horizontal angulation differences of the central x-ray beam increase the risk of underestimating interproximal bone loss by radiographic examination. ${ }^{3}$

Hildebolt, et al. also investigated the effect of changing projection geometry on measurement of the periodontal bone loss. The clinicians concluded that beam positioning errors of less than $10^{\circ}$ did not significantly change a 2-D, conventional radiographic image. ${ }^{24}$ A follow up study by this group studied angulation effects with direct digital radiology and computer enhancements. This study showed that angulation changes of less than $5^{\circ}$ were acceptable. $^{48}$

\section{RADIOGRAPHIC DENSITY}

The density of a radiograph is the overall darkness of the radiograph. Density is measured as the amount of light transmitted through the image. The factors that affect the radiographic density are the milliamperage of the x-ray machine, exposure time, and to a lesser degree the $\mathrm{kVp}$ of the machine. ${ }^{49}$ Therefore, if the milliamperage and $\mathrm{kVp}$ of the $\mathrm{x}$-ray machine are kept constant, the clinician can alter the radiographic density by varying the exposure time. In addition, the density scale of x-ray film is a logarithm of the luminance transmittance and is almost linear to exposure. ${ }^{50}$ Gray scale, or the number of shades of gray in an x-ray image, adopts a linear luminance system that is also linear to exposure. ${ }^{51}$ Therefore, exposure level is increasingly important since small changes in this parameter alter the detectability of small lesions or defects. ${ }^{52}$ Furthermore, gray-scale manipulation is 
the core of the LumenIQ technology. By varying the exposure time and the resultant radiographic density, the effect on the LumenIQ software enhancement can be seen.

Currently, no other studies exist to evaluate the effect of exposure time on the measurement of periodontal defect dimension. A study conducted by Svenson, et.al. investigated the effects of exposure time on caries diagnosis. The results of this study found only a small effect of exposure time on the accuracy of caries diagnosis. Svenson, et. al. reported a $25 \%$ effect of exposure time on accurate caries diagnosis. The other $75 \%$ was attributed to evaluator performance..$^{22}$

\section{DISTRIBUTION OF BONE QUALITY IN THE MANDIBLE}

Bone quality is defined as the description of bone structure which includes the relative amounts and density of cortical and trabecular bone..$^{53}$ The study of dental endosseous implants has provided much information on the variation in bone density/quality which exists in the various regions of the maxilla and mandible. Lekholm and Zarb defined the following four bone qualities. Q-1 is dense homogenous cortical bone with a small trabecular core. Q-2 is a large, dense layer of cortical bone surrounding a dense trabecular core. Q-3 is a thinner layer of cortical bone around a dense trabecular core. Q-4 is a thin cortical layer surrounding a low-density trabecular core. ${ }^{53,54,55}$ In this classification, Q-1 is considered the highest quality bone. Misch also established a clinical classification scheme for the mandible and maxilla based on four densities of available cortical and trabecular bone. D1 is described as being almost completely dense compact bone. D2 is a combination of dense to porous compact cortical bone surrounding coarse trabecular bone. D3 is porous, thinner cortical bone over fine trabecular bone. D4 is composed of little or no cortical bone 
over low-density fine trabecular bone. ${ }^{55}$ In this classification, D1 is considered the highest quality bone.

Many studies have reported on the mechanical properties of cortical and trabecular bone in different anatomic regions. The majority of these studies have focused on long bones and vertebral bodies. Only with the advent of endosseous dental implants have recent studies focused on the different bone densities of the jaws. Morris, et al. found that the anterior mandible had the highest percentage of Q-1 or more dense bone. This study also showed that the majority of the posterior mandible was comprised of Q-2 bone. Therefore, the anterior mandible generally has the highest quality of bone. ${ }^{53}$ In addition, Misch, et al. found that the anterior mandible had the greatest trabecular bone density and cortical thickness, or D2 bone. Also, the posterior mandible was comprised mostly of fine trabecular bone and a thinner cortical plate, or D3 bone..$^{55}$

\section{USE OF RADIOGRAPHIC PHANTOMS}

When exposing radiographs on a living patient, soft tissue scatters the x-ray beam to some extent. For this reason, many different types of solid materials have been used for the simulation of biological tissues. These substances are all referred to as phantoms. A phantom for dental radiography should have a similar range of x-ray attenuation to that of human tissues. In addition, it has been suggested that phantom material should have the same density and number of electrons per gram as the corresponding tissues. ${ }^{56}$ Ott preferred wax-based products. ${ }^{57}$ An isocyanate rubber phantom was used by Anderson, et al. ${ }^{58}$ White, et al. experimented successfully with an epoxy-based phantom. ${ }^{54}$ Therefore, in order to properly simulate $\mathrm{x}$-ray scatter caused by soft tissue, a resin phantom, in the form of intensifying screen material, was placed between the x-ray source and the specimen. Several 
other studies have described and validated resin as an image quality phantom for dental radiography. ${ }^{46,47,59}$

\section{METHODS OF ENHANCED VISUALIZATION}

Dental practitioners are becoming interested in the many different methods that exist for enhanced visualization of radiographs. A recent study shows that although $77 \%$ of dental practitioners in the state of West Virginia were not using digital radiography, 77.9\%

understood that this technology offered certain benefits compared to conventional x-rays. Furthermore, $71.6 \%$ surveyed were aware of the availability of computer software to enhance radiographic images. ${ }^{60}$

Many of the methods of enhanced visualization involve the computer and some form of imaging software. In general, the software allows some of the following features: color enhancement, magnification, gamma adjustment, and three-dimensional enhancement. False color or pseudocolor can be added to an image to increase the ability of the observer to see the contrast between certain areas in the image. The computer accomplishes this by assigning different colors to the various shades of gray in the image. ${ }^{61}$ Since the human eye is sensitive to more colors than shades of gray, this enhancement increases the discriminability of the image by replacing gray shades with pseudocolor. ${ }^{61}$

Another method of enhanced visualization is that of magnification of an image. The computer renders the image at a certain magnification in order to more clearly depict certain areas of the image. However, a limit to the amount of magnification that can be applied exists. Once a certain threshold is reached, the resolution and overall clarity of the image is compromised.

Gamma correction is another method employed to enhance image visualization. 
Gamma correction controls the overall brightness of an image and aids in more accurate display of an image on computer monitors. The amount of gamma correction that is used not only controls the image brightness but also the ratios of red to green to blue. ${ }^{62}$ The concept of gamma arises from the fact that all monitors have a pixel intensity to voltage response curve of about 2.5 power. This simply means that if a pixel should have intensity $x$, then once the monitor processes the signal, the pixel will have intensity $x^{2.5}$. Therefore, monitors are said to have a gamma of 2.5. Because the range of pixel intensities sent to a monitor is between 0 and 1 , if the monitor is not gamma corrected to a value of 2.5, the pixel intensity will tend to be less than it should be (an intensity of $0.5^{2.5}=0.177$ ). ${ }^{62}$ So, in order to produce an accurate portrayal of a real-world object on a computer monitor, the gamma can be corrected.

Three-dimensional image enhancement is probably the newest form currently under investigation. One method of producing a 3-D image is by Cone-Beam Computed Tomography. The x-ray unit and image intensifier rotate around the object as the exposure is being completed. A scan will generally produce 365 slices as axial projection data ${ }^{44}$ The data is then transferred to the workstation consisting of a computer with imaging software. From this projection data, the workstation can reconstruct any section in 3-D. ${ }^{44}$ While this technology may prove to increase the discriminability over conventional radiography, the high cost has reduced its availability at this time.

In addition to Cone-Beam Computed Tomography, an even newer method of 3-D image production exists. Computer software such as that of LumenIQ's ImageIQ renders an image on a three-dimensional axis. The actual two-dimensional pixel arrangement of the image is placed on the $\mathrm{X}$ and $\mathrm{Y}$-axes. Then, each gray scale value is assigned a height value, 
which is plotted on the Z-axis. ${ }^{63}$ The human eye can only distinguish approximately 32 of the 256 gray scale values that may be included in an x-ray. The human eye has a much easier time distinguishing differences in line height than gray scale value. ${ }^{32}$ Therefore, more information could be analyzed from an image in this manner than from a conventional 2-D format.

The three-dimensional topographical rendering of an image has many applications. The initial applications of this type of software were in the field of forensic identification. Uses of the software in this field include: forensic document examination, latent finger print identification, ballistics and firearms, bloodstain pattern analysis, footwear analysis, bitemark analysis, and odontology. Only now has the application of this technology to the field of dentistry been investigated. ${ }^{63}$ 


\section{CHAPTER III}

\section{MATERIALS AND METHODS}

\section{Orientation Phase}

12 clinical dental cases consisting of various types of dental radiographs and no identifiable patient markers were compiled. The conventional radiographs of these 12 cases were ranked by a panel of 34 evaluators in comparison to computer-generated 3-D topographical images rendered by the ImageIQ software. This provided a study to prove the value of the project and introduce the software to the evaluators of subsequent project phases. In this orientation phase, suspect clinical areas of pathology as well as anatomical landmarks were compared. Static standard x-ray(s) that were post-processed into a digital format of each landmark/suspect area were re-represented in a computer-generated 3-D topographical manner (ImageIQ format). The two images (conventional x-ray and ImageIQ format) were evaluated first independently, then in parallel (at the same time). The evaluator was then asked a series of questions for each of the conventional radiographs and each of the computer-generated 3-D topographical images, as well as some comparison questions, while the two images were side-by-side. (See Appendix B for actual cases shown and Appendix C for a copy of the questionnaire given) Results were rated based on the evaluator's perception of image detail, clarity, and overall quality as well as confidence and fatigue levels. A metaanalysis of the data compiled from all 12 cases was used to analyze the data. P-values based on 95\% significance were calculated as well. 


\section{Dried Cadaver Mandible Project}

Sixty dried human cadaver mandibles were obtained. Forty mandibles were edentulous and twenty were dentate with existing periodontal defects. Each mandibular specimen was assigned a number for identification purposes. This number was then placed on the mandible and was used to identify subsequent photographic and radiographic images.

A panoramic radiograph using Kodak Extavision G panoramic film was made of all dried cadaver mandibles. In order to simulate soft tissue scatter and gain a more realistic image, a resin soft tissue phantom in the form of 6 layers of intensifying screen material was placed over the panoramic x-ray beam slot. The resultant panoramic radiograph served as a means of screening each mandible for any visible pathology or anatomic irregularity that could have been imaged further.

\section{Edentulous Dried Cadaver Mandible Phase: Simulated Periodontal Bone \\ Defects}

\section{SPECIMEN PREPARATION}

Simulated periodontal defects were placed in the 40 edentulous dried human cadaver mandibles. To allow reproducible images and to quantify beam angulation, a custom angulation jig was created. The jig was modeled after systems used in previous studies. ${ }^{64,65} \mathrm{~A}$ plaster base held each mandible allowing repeatable positioning on the angulation jig. Clear rope wax was placed along the inferior border of the cadaver mandible to protect the mandible from damage and to facilitate easy removal of the mandible from the plaster base at completion of the study. Figure 2 shows this process. 


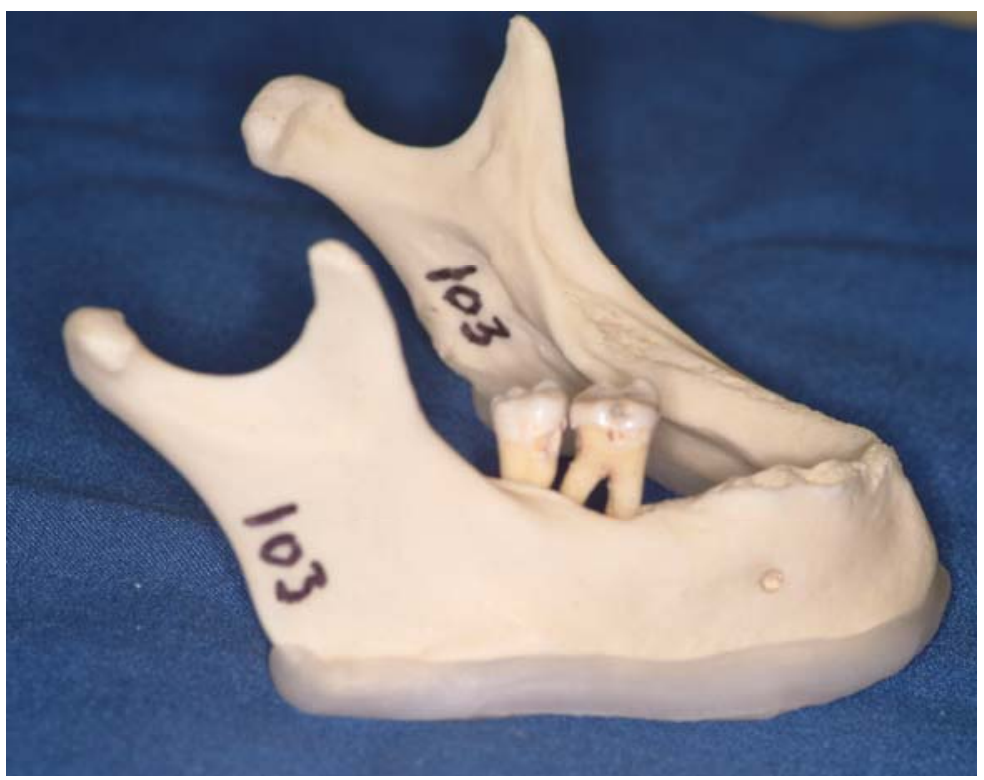

Figure 2. Protection rope wax on inferior border

A plastic mold used for constructing plaster model bases was modified by removal of the posterior portion as seen in Figure 3. This allowed the cadaver mandible to fit inside the base.

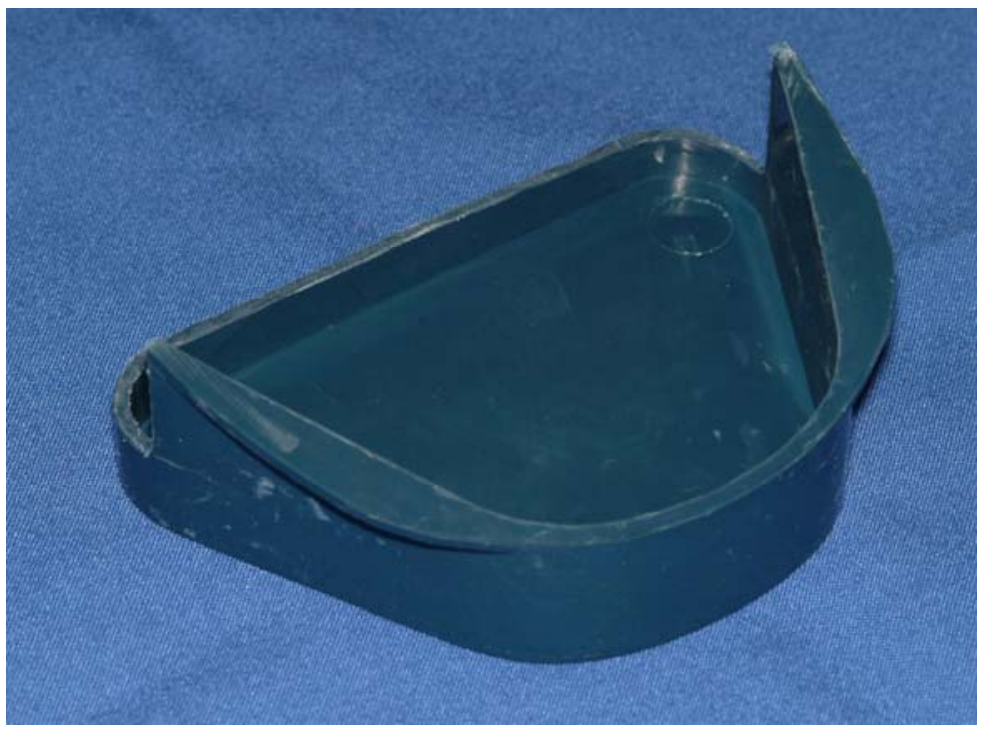

Figure 3. Plaster model base mold modified by removal of posterior portion 
Plaster was then vibrated into the base mold, and the mandible was submerged up to the level of the protective clear rope wax as seen in Figure 4.

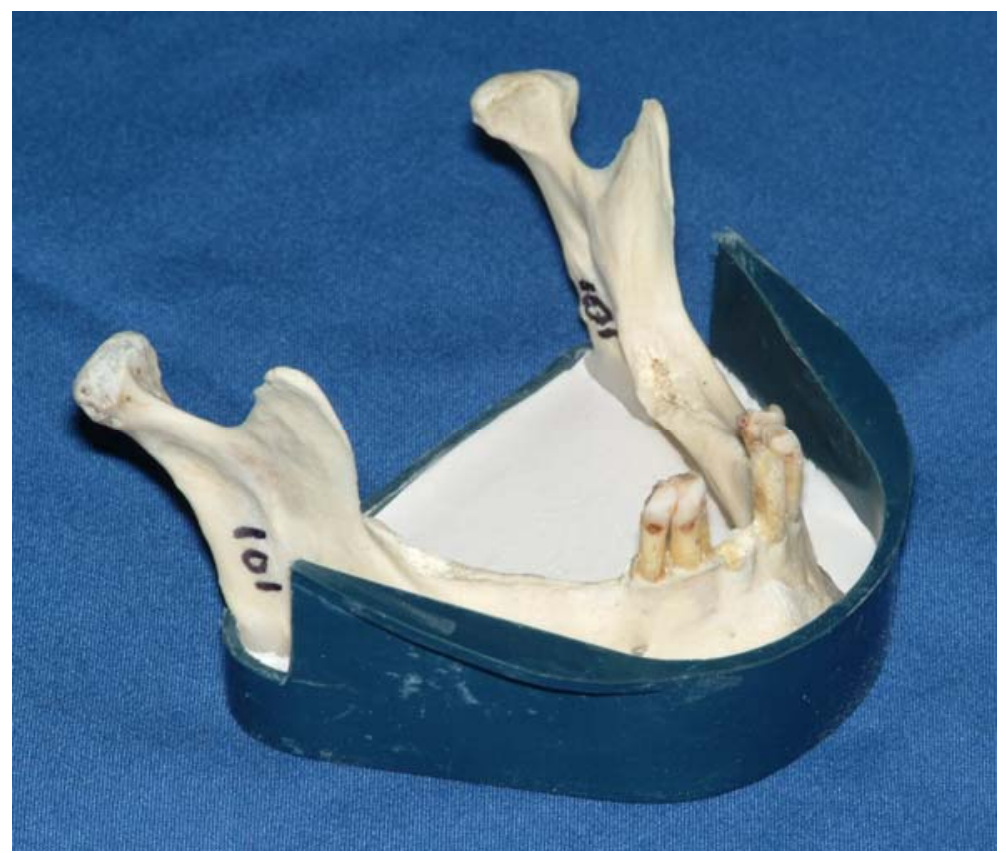

Figure 4. Edentulous dried cadaver mandible set in plaster in base mold

The plaster base was allowed to cure for 45 minutes. Once removed from the base mold, the plaster base was trimmed on a model trimmer so that the sides were parallel to the mandible body. Figure 5 shows the trimmed base. 


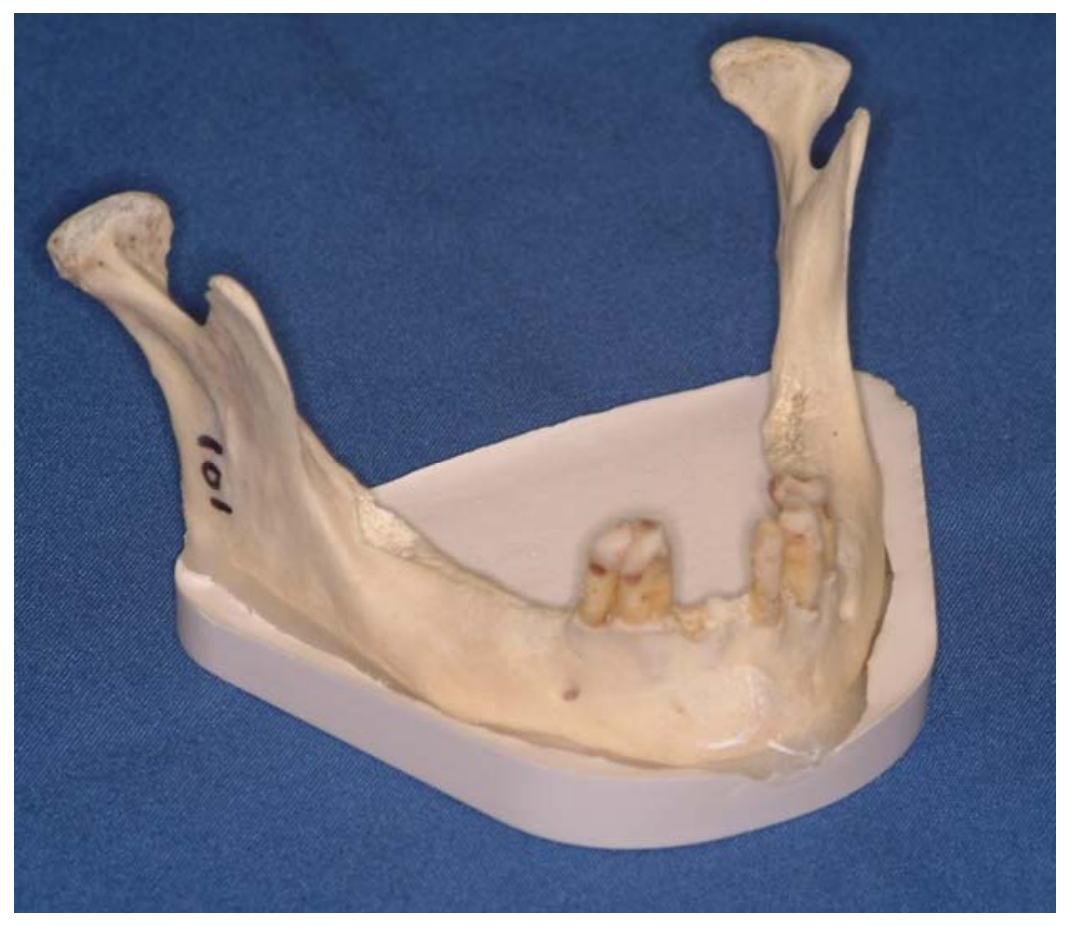

Figure 5. Edentulous dried cadaver mandible in plaster base with sides trimmed

A $1 / 4$ inch diameter hole was drilled through the center of the plaster base. This hole allowed the plaster base to be attached to the angulation jig in a repeatable position. A 1/8inch slit was then cut in the plaster base on the lingual side of the mandible. This slit held the x-ray film in a repeatable position. Figure 6 shows the $1 / 4$ ” hole and 1/8” slit.
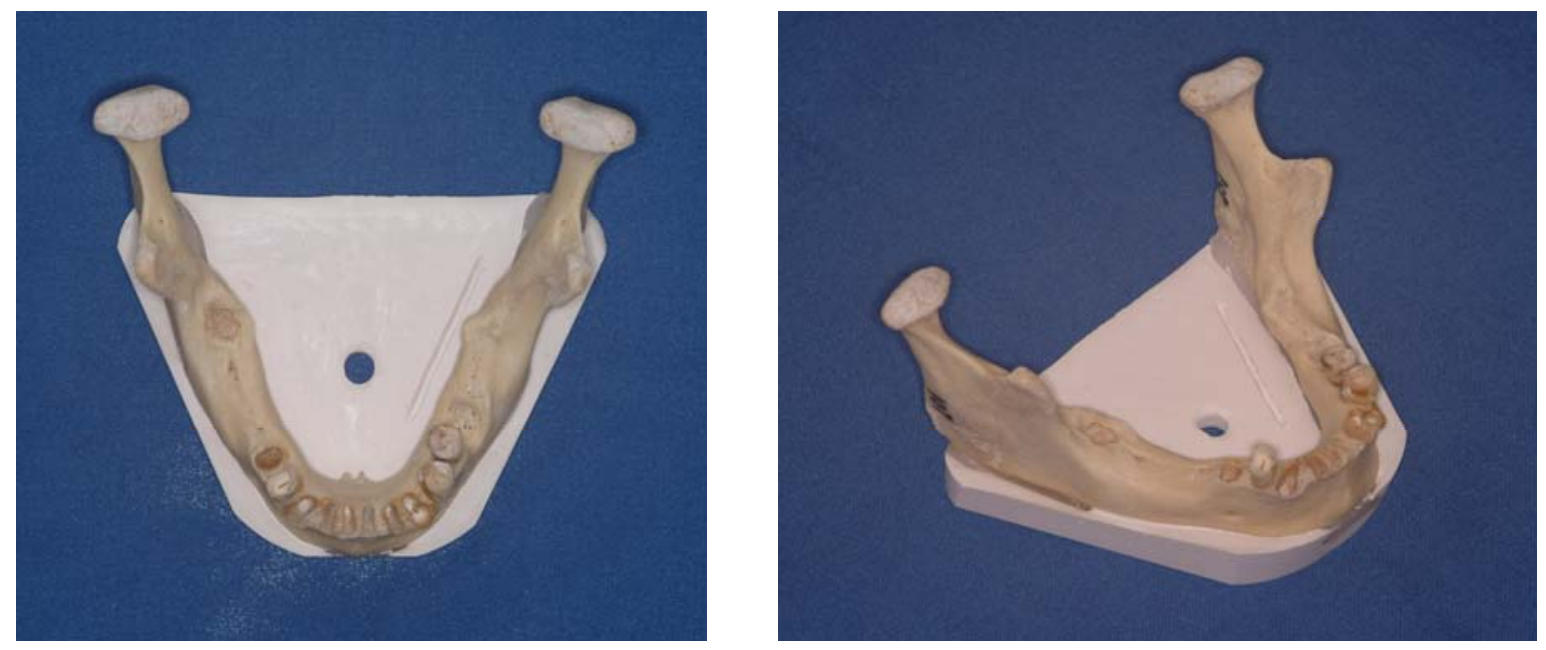

Figure 6. 1/4" central hole and 1/8" slit in plaster base 
The angulation jig used a modified protractor assembly that allowed quantification of $\mathrm{x}$-ray beam angulations and the reproducibility of those angulations.

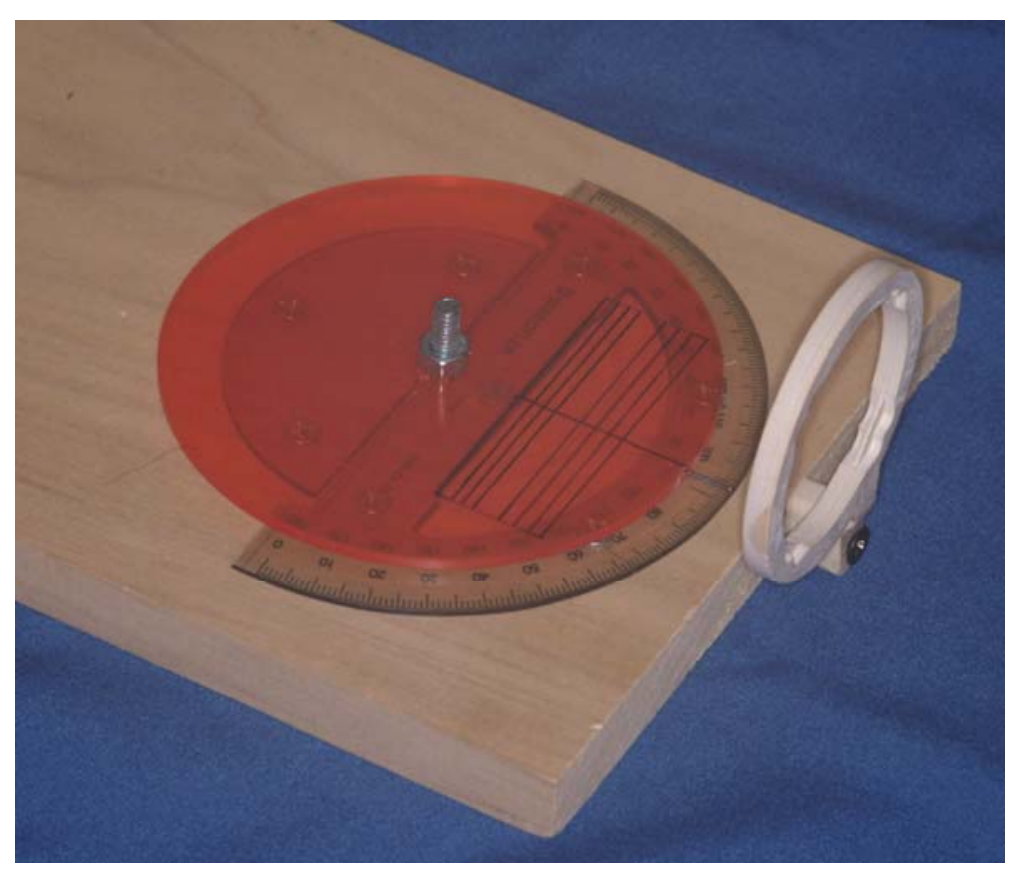

Figure 7. Angulation jig

The mandible, now mounted in a plaster base, was placed onto the angulation jig through the central 1/4" hole and was secured by tightening a bolt. The side of the mandible, which was to be radiographed, was aligned so that the edge of the plaster base was parallel with the reference marks on the angulation jig. These reference marks were placed perpendicular to the pointer, which indicates beam angulation degree on the protractor. Figure 8 shows a close-up view of these reference marks. Figure 9 shows the mandible attached to the angulation jig with the base parallel with the reference marks. 


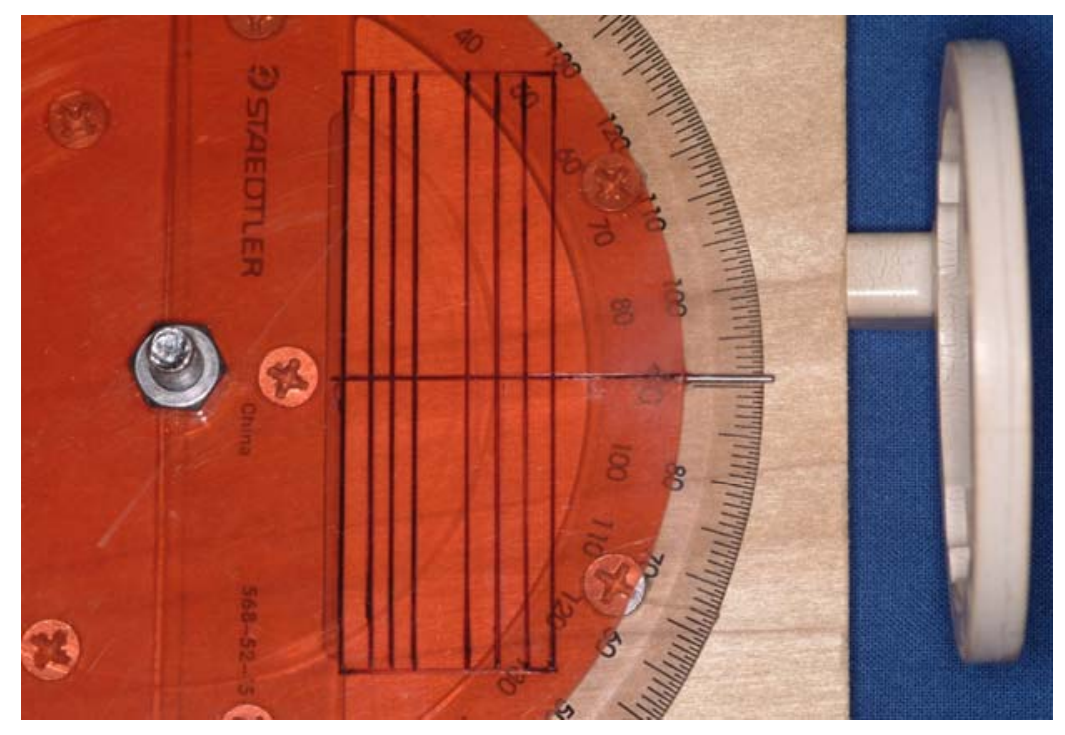

Figure 8. Reference marks on angulation jig placed perpendicular to the pointer

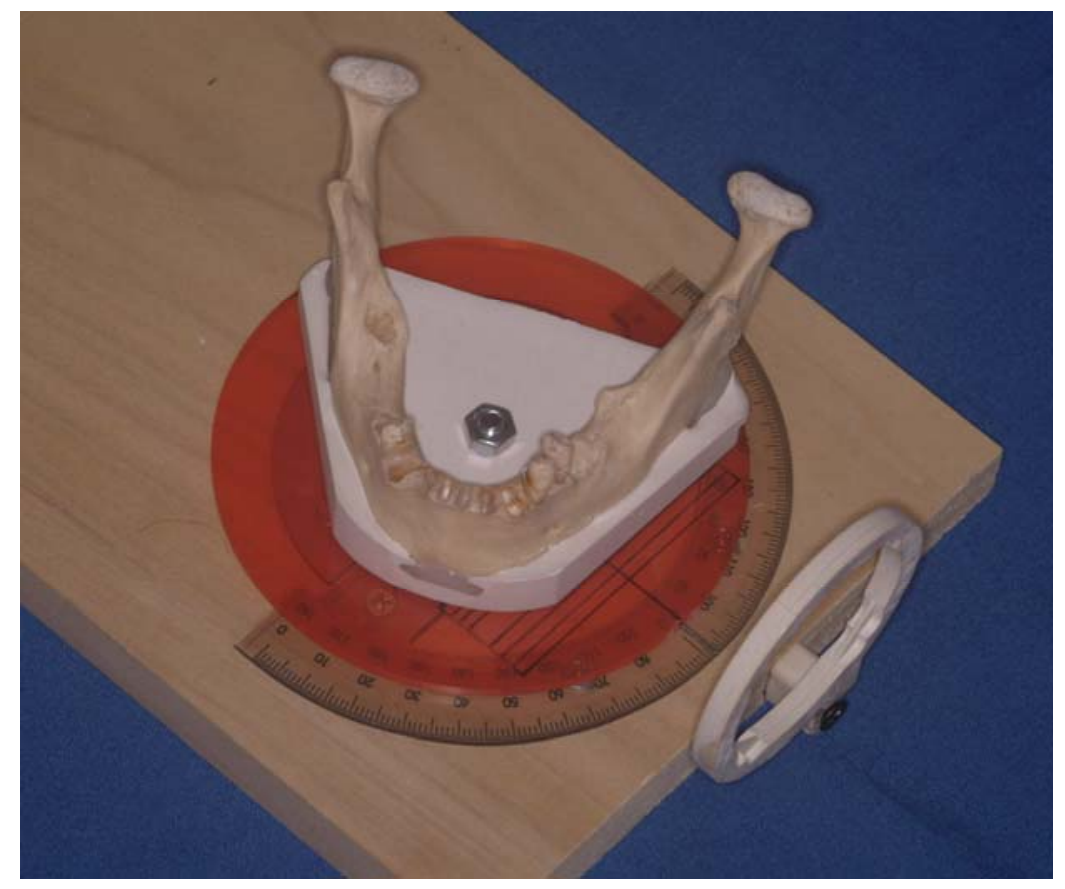

Figure 9. Edentulous cadaver mandible secured on angulation jig with base parallel to reference marks 
To simulate various bony defects, a series of cylinder-shaped simulated periodontal defects were placed in each edentulous dried human cadaver mandible. In order to evaluate any difference in the quality of the ImageIQ rendered image when depicting simulated defects in higher density/quality anterior (D2) bone versus lower density/quality posterior (D3) bone, the defects were placed in the posterior region of the mandibular body between the ramus and the mental foramen and in the anterior region of the mandible between mental foramina. These simulated defects were placed using a custom drill press and various sizes of drill bits. Previous studies using canine mandibles have proven this method of simulated defect fabrication successful. ${ }^{30,39}$ Figure 10 shows the custom drill press used in this study.

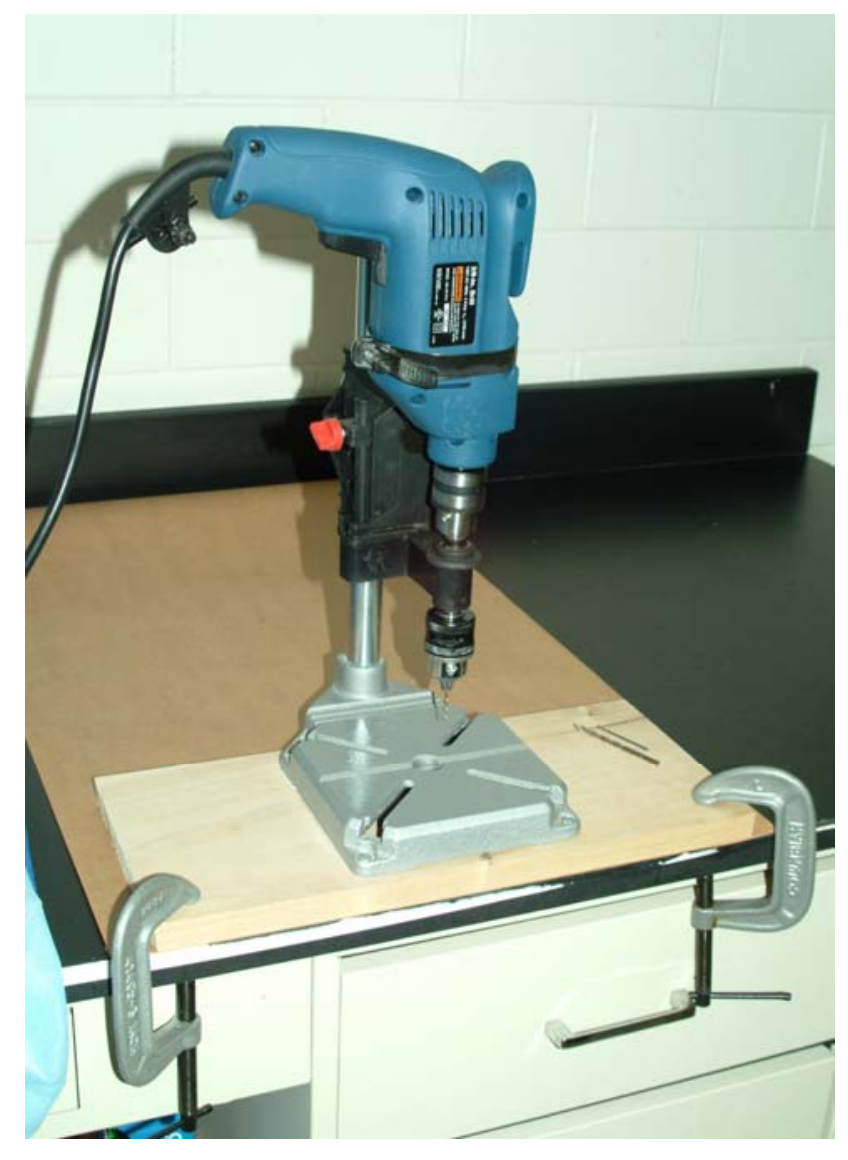

Figure 10. Custom drill press secured on tabletop 
To provide a flat, uniform surface on which to place the defects, the top of each edentulous cadaver mandible was reduced to a flat surface. An acrylic bur in a lab handpiece was used for this task. A dental surveyor was then used to check for uniform flatness of the mandibular bone as shown in Figure 11.

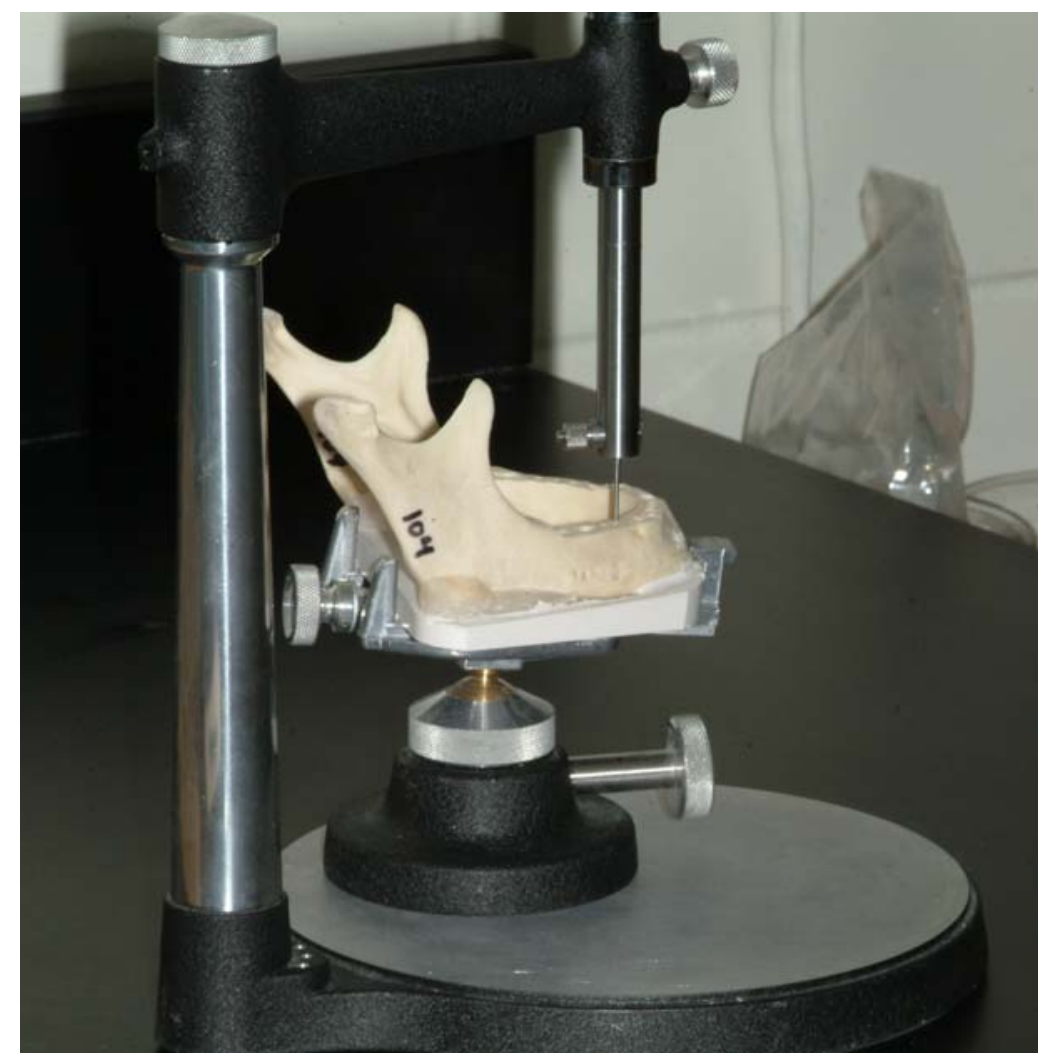

Figure 11. Edentulous dried cadaver mandible on dental surveyor to check for flat surfaces

The first row of defects was intracortical, was placed in random order on the superior surface of mandibular bone with a uniform depth of $6 \mathrm{~mm}$, and had the following diameters: $1 \mathrm{~mm}, 2 \mathrm{~mm}$, and $4 \mathrm{~mm}$. A second row of defects penetrated the cortical bone on the lateral surface of the mandible, had a uniform depth of 3mm, and had the diameters previously mentioned placed in random order. Figure 12 illustrates the configuration of the simulated defects. 
In order to accurately measure the simulated defects that were imaged on the radiographs, a piece of a periodontal probe marked by a radio-opaque endodontic stopper at a length of $6 \mathrm{~mm}$, was embedded into a cylindrical hole $6 \mathrm{~mm}$ in depth and $1 \mathrm{~mm}$ in diameter. This probe was placed next to each group of simulated defects. The probe provided a means to overcome the radiographic magnification factor and also provided a calibrated measuring device for the simulated defects.

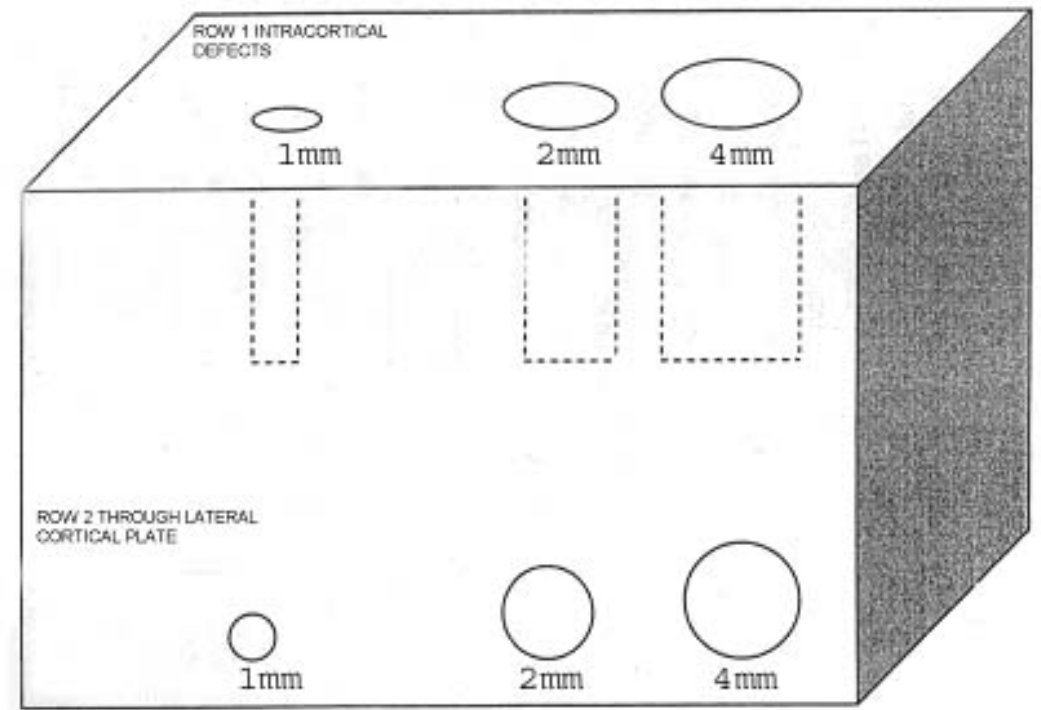

Figure 12. Simulated periodontal defect arrangement (note: actual arrangement was randomized) 


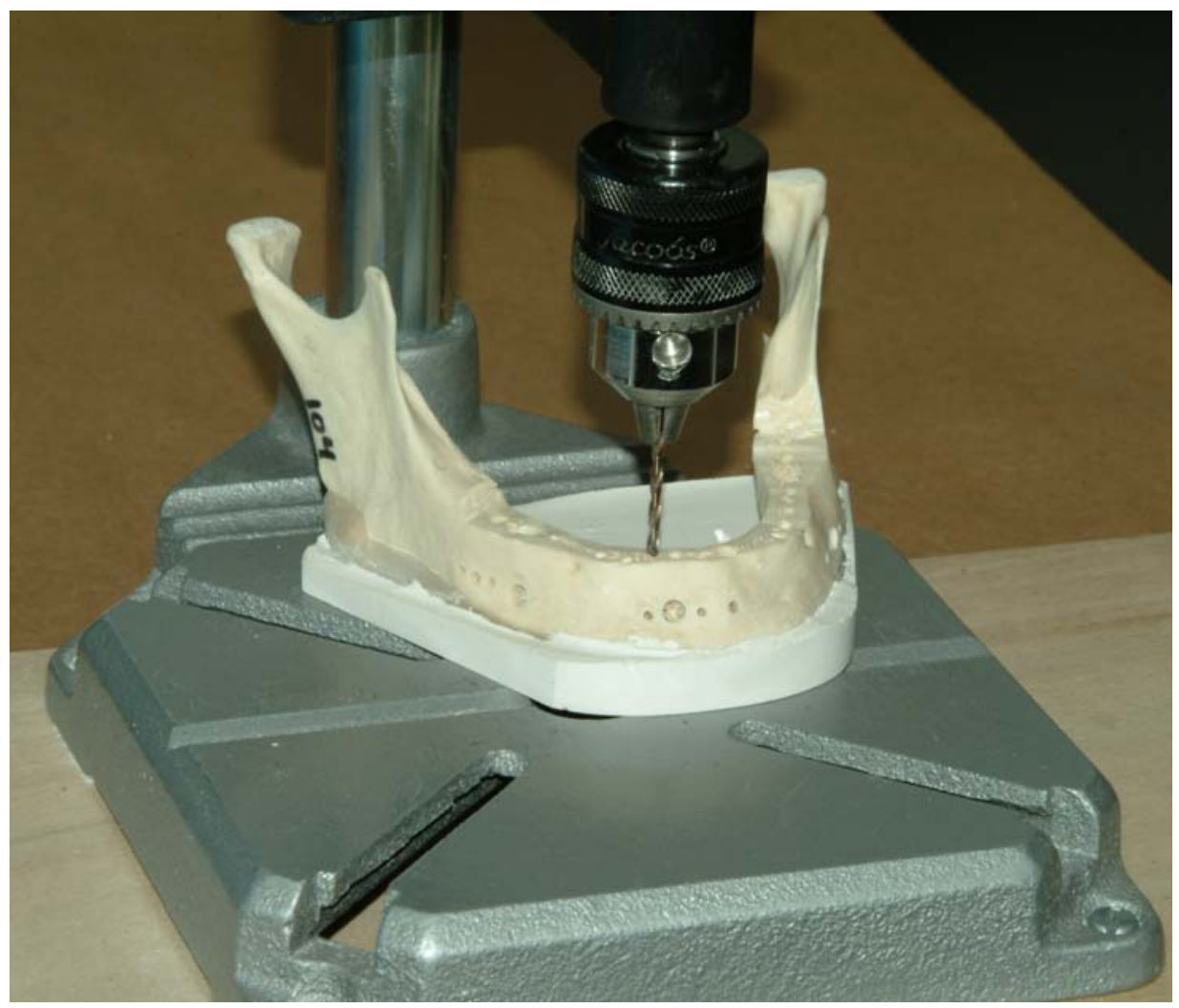

Figure 13. Edentulous dried cadaver mandible on custom drill press

\section{RADIOGRAPHIC EXAMINATION}

Simulated periodontal defects placed in the anterior and posterior mandible were radiographed using D-speed \#2 size radiographs (Kodak Ultraspeed \#2). Several recent studies have evaluated the accuracy of various film speeds. D-speed film has been found statistically superior to E-speed film in determining such precise measurements as radiographic endodontic working length both in vitro ${ }^{66}$ and in vivo.$^{67}$ Resin phantom material was placed over the tubehead to represent soft tissue scatter as in previous studies. ${ }^{46,47,59}$ Conventional radiography performed with D-speed \#2 size radiographs was compared to the ImageIQ computer-generated 3-D topographical renderings. For every specimen one Dspeed \#2 size radiograph was taken with the x-ray beam perpendicular or $90^{\circ}$ to the specimen. 
The exposure time was kept the same for these films, i.e. 12 impulses. The exposure time of 12 impulses had been determined by trial and error to provide the best quality of cadaver mandible radiograph. Then, radiographs were taken with the $\mathrm{x}$-ray beam perpendicular or $90^{\circ}$ to the specimen at the following exposure times: 8 and 18 impulses. Finally, radiographs were taken with the $\mathrm{x}$-ray beam at $10^{\circ}$ and $20^{\circ}$ to the horizontal plane at a constant exposure time of 12 impulses. This portion of the study was modeled after a similar study performed by Chai-U-Dom and colleagues. This group radiographed dry human skulls with simulated periodontal defects at $10^{\circ}, 20^{\circ}$, and $30^{\circ}$ to evaluate the effect of angular disparity. ${ }^{68}$ The custom made plaster bases and angulation jig allowed accurate measurement and reproduction of these beam angulations.

The \#2 size films were exposed using a Gendex GX-770 X-ray machine at 70kVp and 7mA. The films were processed using the Airtechniques A/T2000 processor on a 5.5-minute cycle. Readymatic Dental Chem Pack Processing Chemicals were used and replenished with fresh solutions after every 100 radiographs.

The processed radiographs were then digitized using the Epson Expression 1680 flatbed scanner. Previous studies had proven the ability of a flatbed scanner to produce high quality digitized radiographs when compared with other means of digitization. ${ }^{69,70,71}$ The scanner was set to transparency mode, 8-bit gray-scale and a resolution of 300 dots per inch was used. The use of the transparency mode ${ }^{69}$ and 8-bit gray-scale setting ${ }^{70}$ had been studied previously. Janhom, et al. investigated the scanning resolution that provided the highest quality of digitized radiograph. Their study showed that a resolution of 300 dots per inch provided a manageable file size without significant loss of image quality. ${ }^{72}$ Others have found similar results and recommended a resolution of 300 dots per inch. ${ }^{73,74}$ The resultant 
unmodified digitized radiograph was saved in a Tagged Image File Format (TIFF) and archived on CD-ROM. Gurdal, et al. investigated the effects of different file formats on digital radiographs. Their study concluded that digital radiographs saved as TIFF files were more accurate than those saved in another popular format, the Joint Photographic Experts Group (JPEG) format. ${ }^{75}$

Each digitized radiograph was then rendered into a three-dimensional image using the ImageIQ software on a compatible Windows based personal computer. The rendered image was saved in a TIFF file format and archived on CD-ROM.

\section{IMAGE EVALUATION}

Each digitized radiograph and its ImageIQ 3-D topographic rendering was compared for discriminability by the principal investigator. Using the embedded periodontal probe marked at $6 \mathrm{~mm}$, the investigator calibrated measurement of the simulated defects. The diameter of each defect placed in the cortical bone of the lateral surface of the mandibles was measured at its widest dimension in millimeters on the conventional radiograph and the topographical rendering. The width and length of each defect placed intracortically was measured at their widest dimension in millimeters on both the conventional x-ray and the topographical rendering. These measurements were entered into a Microsoft Excel spreadsheet.

\section{STATISTICAL ANALYSIS}

To analyze the data, a data table was set up in Microsoft Excel. The columns were labeled “conventional radiograph” or "ImageIQ rendering” as well as with “length”, “width”, or "diameter". The rows were labeled with the mandible identification number and defect 
location. Each defect dimensional measurement was entered in the corresponding cell. The difference between the 2-D conventional radiographic measurements and the computer generated topographical rendering were calculated using the ANOVA test. These differences were evaluated based on variables, which included: defect location in the mandible, defect size, and x-ray beam exposure time and angulation. P-values based on 95\% significance were calculated as well.

\section{Dentate Dried Cadaver Mandible Phase}

\section{SPECIMEN PREPARATION}

A photographic archive of the 20 dentate dried human cadaver mandibles was made. Four digital photographs were taken of each specimen from the following perspectives: occlusal, anterior, and right and left lateral. These digital images were produced using a Fuji Finepix S2 SLR 6.3 mega-pixel digital camera. The images were saved in TIFF format and archived on CD ROM. In some cases, a periodontal probe was placed in an area of interest and close-up photography of the area was employed. This photographic archive served as a reference showing any existing periodontal defects that were present. Had the mandibles been compromised in any manner that would not have allowed further inspection, the archive would have served as a usable record of these defects.

The principal investigator located the existing periodontal defects in each dentate cadaver mandible. A total of 63 periodontal defects were found. The locations of these defects were recorded in a Microsoft Excel spreadsheet. The principal investigator then classified each periodontal defect according to the 1, 2, and 3-wall classification scheme discussed in the literature review. ${ }^{5}$ This classification was also placed in the Microsoft Excel spreadsheet. 


\section{RADIOGRAPHIC EXAMINATION}

Any periodontal defect seen by either visual or photographic examination or by panoramic radiograph (Kodak Extavision G) was then radiographed using D-speed \#2 size radiographs (Kodak Ultraspeed \#2). Several recent studies have evaluated the accuracy of various film speeds. D-speed film has been found statistically superior to E-speed film in determining such precise measurements as radiographic endodontic working length both in vitro ${ }^{66}$ and in vivo. ${ }^{67}$ Resin phantom material was placed over the tubehead to represent soft tissue scatter as in previous studies. ${ }^{46,47,59}$ Conventional radiography performed with D-speed \#2 size radiographs was compared to the computer-generated 3-D topographical images of LumenIQ’s Image IQ software. For every specimen, these radiographs were taken with the $\mathrm{x}$-ray beam perpendicular or $90^{\circ}$ to the specimen in both the horizontal and vertical dimensions. The exposure time was kept the same for these films at 12 impulses. The exposure time of 12 impulses was determined by trial and error to provide the best quality of cadaver mandible radiograph.

The \#2 size D-speed films were exposed using a Gendex GX-770 X-ray machine at $70 \mathrm{kVp}$ and $7 \mathrm{~mA}$. The films were processed using the Airtechniques A/T2000 processor on a 5.5-minute cycle. Readymatic Dental Chem Pack Processing Chemicals were used and replenished with fresh solutions after every 100 radiographs.

The processed radiographs were then digitized using the Epson Expression 1680 flatbed scanner. Previous studies have proven the ability of a flatbed scanner to produce high quality digitized radiographs when compared with other means of digitization. ${ }^{69,70,71}$ The scanner was set to transparency mode, 8-bit gray-scale, and a resolution of 300 dots per inch was used. The use of the transparency mode ${ }^{69}$ and 8-bit gray-scale setting ${ }^{71}$ had been studied 
previously. Janhom, et al. investigated the scanning resolution that provided the highest quality and most efficient file size for digitized radiographs. Their study showed that a resolution of 300 dots per inch provided a manageable file size without significant loss of image quality. ${ }^{72}$ Others have found similar results and recommended a resolution of 300 dots per inch. ${ }^{73,74}$ The resultant unmodified digitized radiograph was saved in a Tagged Image File Format (TIFF) and archived on CD-ROM. Gurdal, et al. investigated the effects of different file formats on digital radiographs. Their study concluded that digital radiographs saved as TIFF files were more accurate than those saved in another popular format, the Joint Photographic Experts Group (JPEG) format. ${ }^{75}$

Each digitized radiograph was then rendered into computer-generated 3-D topographical images using LumenIQ’s ImageIQ software on a compatible Windows based personal computer. The enhanced image was saved in a TIFF file format and archived on CD-ROM

\section{IMAGE EVALUATION}

Each digitized radiograph and its ImageIQ computer-generated 3-D topographical rendering was compared for discriminability by two periodontists and one oral pathologist. These evaluators were standardized for periodontal defect classification using the 1, 2, or 3walled classification system prior to the data collection. All 2-D and 3-D images were compiled and arranged in random order. The evaluators were shown the conventional digitized 2-D radiographs and the ImageIQ topographical 3-D renderings in this random ordering. Each evaluator then classified the existing periodontal defects in the images. This information was placed in a Microsoft Excel spreadsheet. 


\section{STATISTICAL ANALYSIS}

To analyze the data, a data table was set up in Microsoft Excel. The rows were labeled with the specimen identification number and periodontal defect location. The columns were labeled with "Evaluator A, B, or C" and "Standard x-ray" or "Topographical Map”. The evaluator's classification of each periodontal defect was then entered in the

corresponding cell. ANOVA, Student's t-test, and Least Squares Means tests were used to analyze the data. The p-value was set to 0.05 for $95 \%$ significance. 


\section{CHAPTER IV}

\section{RESULTS AND DISCUSSION}

\section{RESULTS}

\section{ORIENTATION PHASE}

The statistical analysis for this phase of the study is located in Appendix D.

Table 1 shows the percentage of evaluators who preferred either the 2-D conventional radiograph or the 3-D computer-generated topographical map in terms of image clarity. The evaluators felt that the topographical map was superior in 9 out of 12 of the cases. The conventional 2-D x-ray was preferred in only 2 of the 12 cases, and one case (case 7) showed identical preference from each type of image. The percentages that supported the topographical map were statistically significant in 5 out of 12 cases.

Table 2 shows the percentage of evaluators who preferred either the 2-D conventional radiograph or the 3-D computer-generated topographical map based on image detail. Those percentages that were significant are denoted with an asterisk (*). The evaluators felt that the topographical map was superior in 9 out of 12 cases shown. The conventional 2-D x-ray was preferred in 2 out of 12 cases. The percentages that supported the topographical map were statistically significant in 6 out of 12 cases. 
Table 1. Comparison of conventional 2-D x-ray and 3-D topographical map based on clarity.

(*) Denotes statistical significance

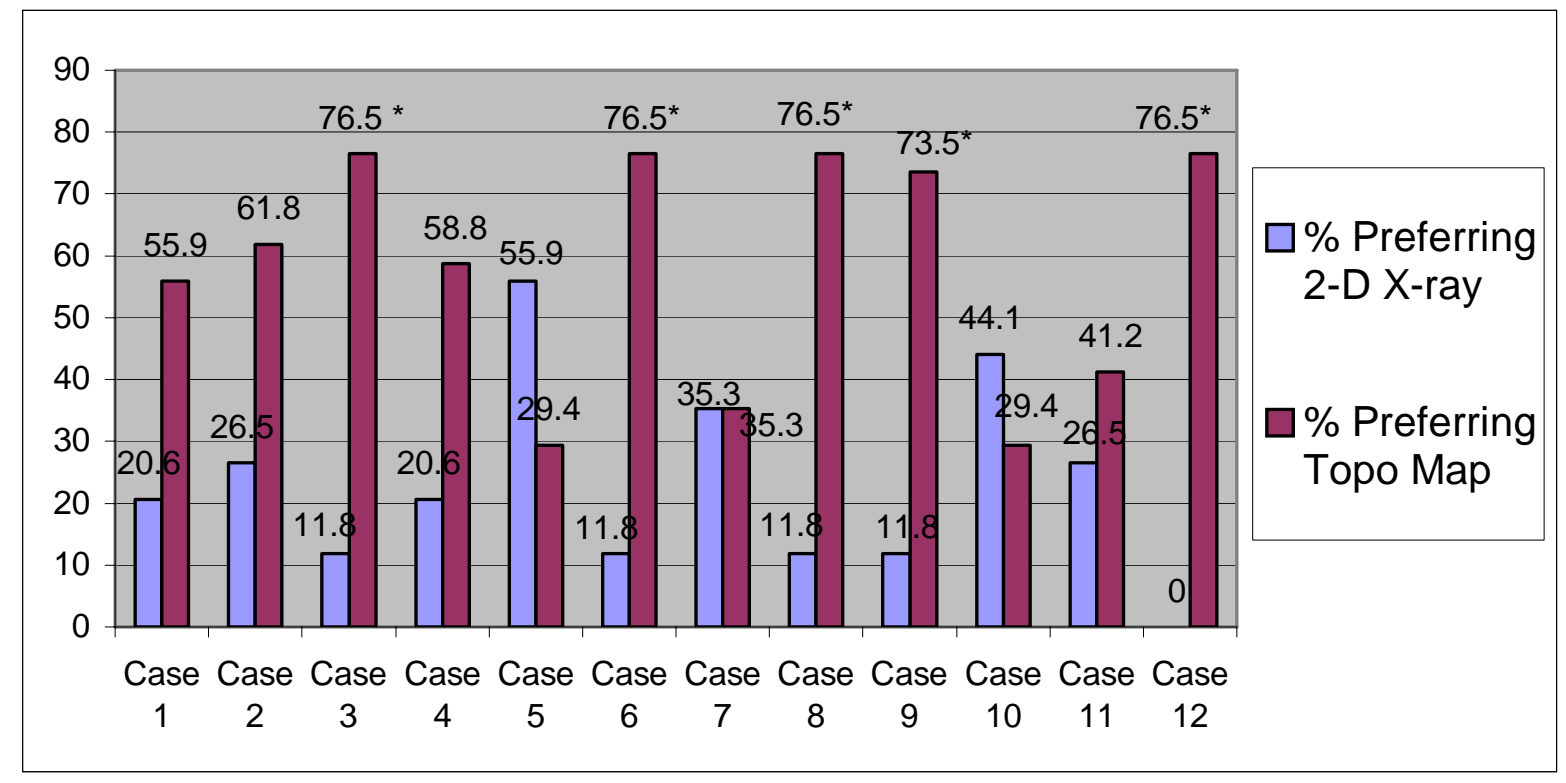

Table 2. Comparison of conventional 2-D x-ray and 3-D topographical map based on detail (*) Denotes statistical significance.

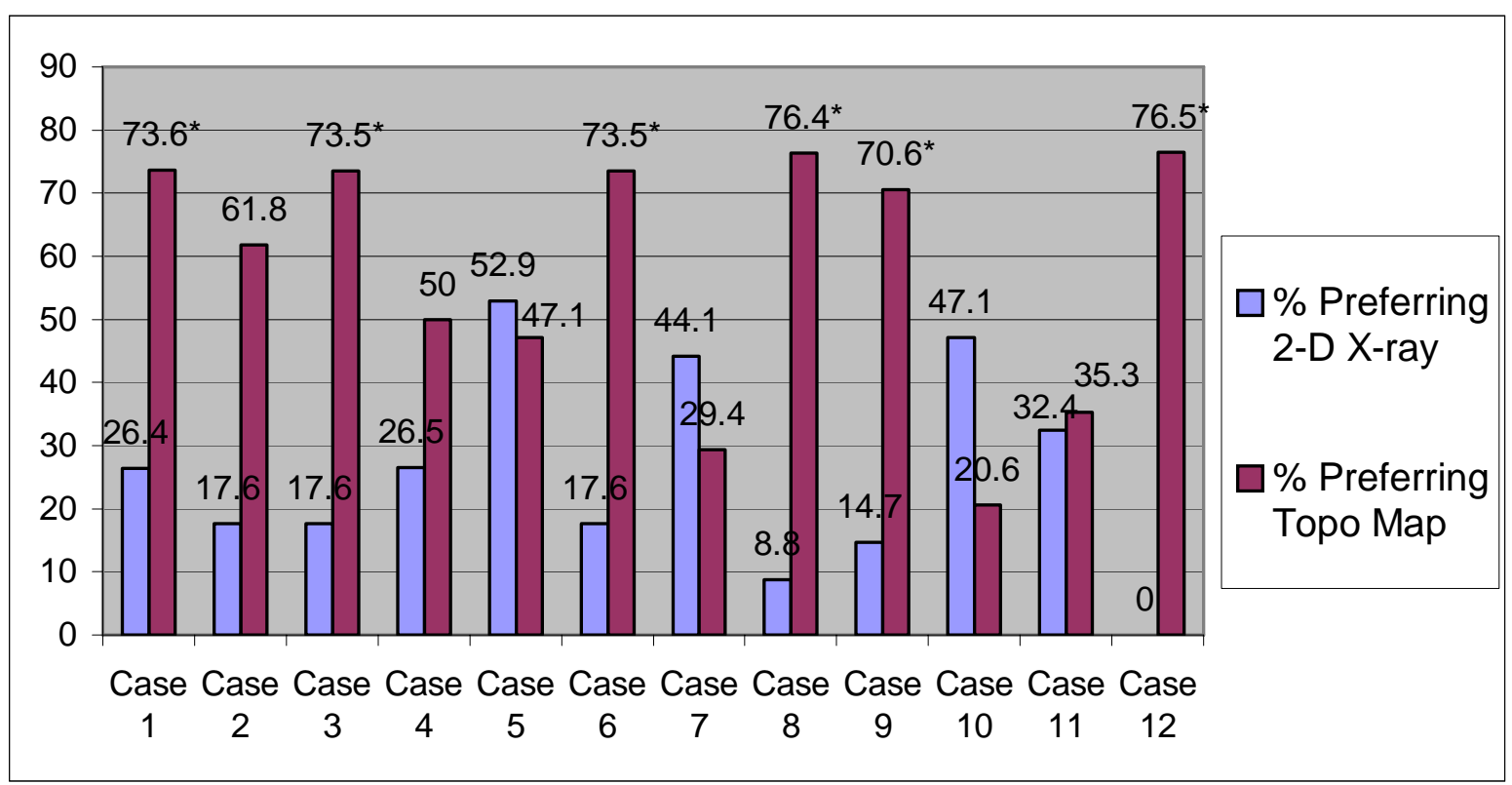


Table 3 shows the statistical significance of the preference for either type of image in terms of image quality, confidence level (how sure of answer choice) and fatigue level (how much strain was needed). For perceived image quality, the 3-D topographical map had statistically significantly greater image quality in only 2 out 12 cases. Likewise, the 2-D conventional radiograph had statistically significant greater quality in 4 out of 12 cases.

In terms of the evaluator's confidence level in their decision, higher confidence in the topographical map was statistically significant in 2 out of 12 cases versus 1 out of 12 cases for the conventional radiograph. On the basis of fatigue level, a higher level of fatigue was statistically significant for the topographical map in 5 out of 12 cases versus just 1 out of 12 cases for the conventional radiograph. 
Table 3. Statistical significance of the preference for either image type based on quality, confidence, and fatigue.

\begin{tabular}{|c|c|c|c|c|c|c|}
\hline \multirow[t]{2}{*}{ Case \# } & \multicolumn{2}{|c|}{ Image Quality } & \multicolumn{2}{|c|}{ Confidence Level } & \multicolumn{2}{|c|}{ Fatigue Level } \\
\hline & $\begin{array}{l}\text { Sig } \\
\text { greater } \\
\text { for 2-D }\end{array}$ & $\begin{array}{c}\text { Sig } \\
\text { greater for } \\
\text { 3-D }\end{array}$ & $\begin{array}{l}\text { Sig } \\
\text { greater } \\
\text { for 2-D }\end{array}$ & $\begin{array}{l}\text { Sig } \\
\text { greater } \\
\text { for 3-D }\end{array}$ & $\begin{array}{l}\text { Sig } \\
\text { greater } \\
\text { for 2-D }\end{array}$ & $\begin{array}{c}\text { Sig } \\
\text { greater for } \\
\text { 3-D }\end{array}$ \\
\hline 1 & & * & & & & * \\
\hline 2 & & & & & & \\
\hline 3 & & & & * & & * \\
\hline 4 & & * & & & & \\
\hline 5 & $\star$ & & & & & * \\
\hline 6 & & & * & & * & \\
\hline 7 & & & & & & \\
\hline 8 & * & & & * & & * \\
\hline 9 & * & & & & & * \\
\hline 10 & & & & & & \\
\hline 11 & & & & & & \\
\hline 12 & * & & & & & \\
\hline
\end{tabular}




\section{EDENTULOUS DRIED CADAVER MANDIBLE PHASE}

The raw data for this phase of the study is located in Appendix E, and the statistical analysis is located in Appendix F.

\section{Impulses, 90 Degrees}

Table 4 shows the comparison between defect diameter, width, and length measurements made using the conventional $\mathrm{x}$-ray and the computer generated topographical rendering based on defect location. Table 5 shows the comparison between defect diameter, width, and length measurements made using the conventional x-ray and the computer generated topographical rendering based on defect size.

Table 4. ANOVA comparison between diameter, width, and length measurements made using the conventional x-ray and the computer generated topographical rendering with 12 impulses 90 degrees based on defect location: Anterior, Posterior

\begin{tabular}{|c|c|c|c|}
\hline \multirow{2}{*}{ Dimension } & Location & $\begin{array}{c}\text { Difference in } \\
\text { Means (3-D - 2-D) }\end{array}$ & \multirow{2}{*}{ Probability } \\
\hline \multirow{2}{*}{ Diameter } & $\mathrm{A}$ & 0.00228 & \multirow{2}{*}{0.8943} \\
\cline { 2 - 3 } & $\mathrm{P}$ & 0.01159 & \multirow{2}{*}{0.7898} \\
\hline \multirow{2}{*}{ Width } & $\mathrm{A}$ & -0.03619 & \multirow{2}{*}{0.2192} \\
\hline \multirow{2}{*}{ Length } & $\mathrm{P}$ & -0.01689 & -0.27670 \\
\cline { 2 - 3 } & $\mathrm{A}$ & -0.53589 & \\
\hline
\end{tabular}


Table 5. ANOVA comparison between diameter, width, and length measurements made using the conventional x-ray and the computer generated topographical rendering with 12 impulses, 90 degrees based on defect size: $1 \mathrm{~mm}, 2 \mathrm{~mm}, 4 \mathrm{~mm}$

\begin{tabular}{|c|c|c|c|}
\hline Dimension & Size & $\begin{array}{c}\text { Difference in } \\
\text { Means (3-D - 2-D) }\end{array}$ & \multirow{2}{*}{ Probability } \\
\hline \multirow{3}{*}{ Diameter } & $1 \mathrm{~mm}$ & -0.05293 & \multirow{2}{*}{0.1751} \\
\cline { 2 - 3 } & $2 \mathrm{~mm}$ & -0.01634 & \\
\cline { 2 - 3 } & $4 \mathrm{~mm}$ & 0.09110 & \multirow{2}{*}{0.0070} \\
\hline \multirow{3}{*}{ Width } & $1 \mathrm{~mm}$ & 0.02569 & \\
\cline { 2 - 3 } & $2 \mathrm{~mm}$ & 0.05524 & \multirow{2}{*}{0.6180} \\
\cline { 2 - 3 } & $4 \mathrm{~mm}$ & -0.14123 & \\
\hline \multirow{3}{*}{ Length } & $1 \mathrm{~mm}$ & -0.47370 & \\
\cline { 2 - 3 } & $2 \mathrm{~mm}$ & -0.35900 & \\
\cline { 2 - 3 } & $4 \mathrm{~mm}$ & -0.35967 & \\
\hline
\end{tabular}

\section{Impulses, +10 Degrees}

Table 6 shows the comparison between defect diameter, width, and length measurements made using the conventional $\mathrm{x}$-ray and the computer generated topographical rendering based on defect location. Table 7 shows the comparison between defect diameter, width, and length measurements made using the conventional $\mathrm{x}$-ray and the computer generated topographical rendering based on defect size.

Table 6. ANOVA comparison between diameter measurements made using the conventional $\mathrm{x}$-ray and the computer generated topographical rendering with 12 impulses, +10 degrees based on defect location: Anterior, Posterior

\begin{tabular}{|c|c|c|c|}
\hline \multirow{2}{*}{ Dimension } & Location & $\begin{array}{c}\text { Difference in } \\
\text { Means (3-D - 2-D) }\end{array}$ & \multirow{2}{*}{ Probability } \\
\hline \multirow{2}{*}{ Diameter } & $\mathrm{A}$ & -0.07860 & \multirow{2}{*}{0.1345} \\
\cline { 2 - 3 } & $\mathrm{P}$ & 0.04007 & \multirow{2}{*}{0.8007} \\
\hline \multirow{2}{*}{ Width } & $\mathrm{A}$ & -0.02682 & 0.02355 \\
\hline \multirow{2}{*}{ Length } & $\mathrm{P}$ & -0.28895 & \multirow{2}{*}{0.1392} \\
\cline { 2 - 3 } & $\mathrm{A}$ & -0.36383 & \\
\hline
\end{tabular}


Table 7. ANOVA comparison between diameter, width, and length measurements made using the conventional $\mathrm{x}$-ray and the computer generated topographical rendering with 12 impulses, +10 degrees based on defect size: $1 \mathrm{~mm}, 2 \mathrm{~mm}, 4 \mathrm{~mm}$

\begin{tabular}{|c|c|c|c|}
\hline Dimension & Size & $\begin{array}{c}\text { Difference in } \\
\text { Means (3-D - 2-D) }\end{array}$ & \multirow{2}{*}{ Probability } \\
\hline \multirow{3}{*}{ Diameter } & $1 \mathrm{~mm}$ & -0.07732 & \multirow{2}{*}{0.3050} \\
\cline { 2 - 3 } & $2 \mathrm{~mm}$ & 0.04451 & \\
\cline { 2 - 3 } & $4 \mathrm{~mm}$ & -0.01195 & \multirow{2}{*}{0.0795} \\
\hline \multirow{3}{*}{ Width } & $1 \mathrm{~mm}$ & 0.06619 & \\
\cline { 2 - 3 } & $2 \mathrm{~mm}$ & 0.00831 & \multirow{2}{*}{0.1244} \\
\cline { 2 - 3 } & $4 \mathrm{~mm}$ & -0.08097 & \\
\hline \multirow{3}{*}{ Length } & $1 \mathrm{~mm}$ & -0.43804 & \\
\cline { 2 - 3 } & $2 \mathrm{~mm}$ & -0.37218 & \\
\cline { 2 - 3 } & $4 \mathrm{~mm}$ & -0.21066 & \\
\hline
\end{tabular}

\section{Impulses, +20 Degrees}

Table 8 shows the comparison between defect diameter, width, length measurements made using the conventional $\mathrm{x}$-ray and the computer generated topographical rendering based on defect location. Table 9 shows the comparison between defect diameter, width, length measurements made using the conventional $x$-ray and the computer generated topographical rendering based on defect size.

Table 8. ANOVA comparison between diameter, width, and length measurements made using the conventional $\mathrm{x}$-ray and the computer generated topographical rendering with 12 impulses, +20 degrees based on defect location: Anterior, Posterior

\begin{tabular}{|c|c|c|c|}
\hline Dimension & Location & Difference in Means (3-D - 2-D) & Probability \\
\hline \multirow{2}{*}{ Diameter } & $\mathrm{A}$ & -0.05623 & \multirow{2}{*}{0.3383} \\
\cline { 2 - 3 } & $\mathrm{P}$ & -0.04583 & \\
\hline \multirow{2}{*}{ Width } & $\mathrm{A}$ & -0.07393 & \multirow{2}{*}{0.1319} \\
\cline { 2 - 3 } & $\mathrm{P}$ & 0.15660 & \multirow{2}{*}{0.9806} \\
\hline \multirow{2}{*}{ Length } & $\mathrm{A}$ & -0.34989 & \\
\cline { 2 - 3 } & $\mathrm{P}$ & -0.34696 & \\
\hline
\end{tabular}


Table 9. ANOVA comparison between diameter, width, and length measurements made using the conventional x-ray and the computer generated topographical rendering with 12 impulses, +20 degrees based on defect size: $1 \mathrm{~mm}, 2 \mathrm{~mm}, 4 \mathrm{~mm}$

\begin{tabular}{|c|c|c|c|}
\hline Dimension & Size & Difference in Means (3-D - 2-D) & Probability \\
\hline \multirow{3}{*}{ Diameter } & $1 \mathrm{~mm}$ & -0.04671 & \multirow{3}{*}{0.3437} \\
\cline { 2 - 3 } & $2 \mathrm{~mm}$ & 0.03585 & \\
\cline { 2 - 3 } & $4 \mathrm{~mm}$ & -0.14110 & \multirow{3}{*}{0.5135} \\
\hline \multirow{3}{*}{ Width } & $1 \mathrm{~mm}$ & 0.03082 & \\
\cline { 2 - 3 } & $2 \mathrm{~mm}$ & 0.09133 & \multirow{3}{*}{0.1068} \\
\cline { 2 - 3 } & $4 \mathrm{~mm}$ & -0.02919 & \\
\hline \multirow{3}{*}{ Length } & $1 \mathrm{~mm}$ & -0.45354 & \\
\cline { 2 - 4 } & $2 \mathrm{~mm}$ & -0.45365 & \\
\cline { 2 - 4 } & $4 \mathrm{~mm}$ & -0.19323 & \\
\hline
\end{tabular}

\section{Impulses, 90 Degrees}

Table 10 shows the comparison between defect diameter, width, and length

measurements made using the conventional x-ray and the computer generated topographical rendering based on defect location. Table 11 shows the comparison between defect diameter, width, and length measurements made using the conventional x-ray and the computer generated topographical rendering based on defect size.

Table 10. ANOVA comparison between diameter, width, and length measurements made using the conventional $\mathrm{x}$-ray and the computer generated topographical rendering with 8 impulses, 90 degrees based on defect location: Anterior, Posterior

\begin{tabular}{|c|c|c|c|}
\hline \multirow{2}{*}{ Dimension } & Location & $\begin{array}{c}\text { Difference in } \\
\text { Means (3-D - 2-D) }\end{array}$ & \multirow{2}{*}{ Probability } \\
\hline \multirow{2}{*}{ Diameter } & $\mathrm{A}$ & -0.0037 & \multirow{2}{*}{0.2494} \\
\cline { 2 - 3 } & $\mathrm{P}$ & -0.2346 & \\
\hline \multirow{2}{*}{ Width } & $\mathrm{A}$ & 0.03046 & \multirow{2}{*}{0.3806} \\
\cline { 2 - 3 } & $\mathrm{P}$ & -0.08407 & \multirow{2}{*}{0.5489} \\
\cline { 2 - 3 } Length & $\mathrm{A}$ & -0.29430 & -0.38731 \\
\hline
\end{tabular}


Table 11. ANOVA comparison between diameter, width, and length measurements made using the conventional x-ray and the computer generated topographical rendering with 8 impulses, 90 degrees based on defect size: 1mm, 2mm, $4 \mathrm{~mm}$

\begin{tabular}{|c|c|c|c|}
\hline Dimension & Size & $\begin{array}{c}\text { Difference in } \\
\text { Means (3-D - 2-D) }\end{array}$ & Probability \\
\hline \multirow{3}{*}{ Diameter } & $1 \mathrm{~mm}$ & 0.0849 & \multirow{3}{*}{0.3817} \\
\hline & $2 \mathrm{~mm}$ & -0.0384 & \\
\hline & $4 \mathrm{~mm}$ & -0.0394 & \\
\hline \multirow{3}{*}{ Width } & $1 \mathrm{~mm}$ & 0.00016 & \multirow{3}{*}{0.0752} \\
\hline & $2 \mathrm{~mm}$ & 0.08890 & \\
\hline & $4 \mathrm{~mm}$ & -0.13716 & \\
\hline \multirow{3}{*}{ Length } & $1 \mathrm{~mm}$ & -0.38154 & \multirow{3}{*}{0.2186} \\
\hline & $2 \mathrm{~mm}$ & -0.046788 & \\
\hline & $4 \mathrm{~mm}$ & -0.22177 & \\
\hline
\end{tabular}

18 Impulses, 90 Degrees

Table 12 shows the comparison between defect diameter, width, and length measurements made using the conventional x-ray and the computer generated topographical rendering based on defect location. Table 13 shows the comparison between defect diameter, width, and length measurements made using the conventional x-ray and the computer generated topographical rendering based on defect size.

Table 12. ANOVA comparison between diameter, width, and length measurements made using the conventional x-ray and the computer generated topographical rendering with 18 impulses, 90 degrees based on defect location: Anterior, Posterior

\begin{tabular}{|c|c|c|c|}
\hline \multirow{2}{*}{ Dimension } & Location & $\begin{array}{c}\text { Difference in } \\
\text { Means (3-D - 2-D) }\end{array}$ & \multirow{2}{*}{ Probability } \\
\hline \multirow{2}{*}{ Diameter } & $\mathrm{A}$ & 0.019649 & \multirow{2}{*}{0.5254} \\
\cline { 2 - 3 } & $\mathrm{P}$ & 0.101742 & \multirow{2}{*}{0.4989} \\
\hline \multirow{2}{*}{ Width } & $\mathrm{A}$ & -0.04701 & \multirow{2}{*}{0.2783} \\
\cline { 2 - 3 } & $\mathrm{P}$ & -0.01227 & -0.26053 \\
\cline { 2 - 3 } & $\mathrm{A}$ & -0.62373 & \\
\hline
\end{tabular}


Table 13. ANOVA comparison between diameter, width, and length measurements made using the conventional x-ray and the computer generated topographical rendering with 18 impulses, 90 degrees based on defect size: $1 \mathrm{~mm}, 2 \mathrm{~mm}, 4 \mathrm{~mm}$

\begin{tabular}{|c|c|c|c|}
\hline \multirow{2}{*}{ Dimension } & Size & $\begin{array}{c}\text { Difference in } \\
\text { Means (3-D - 2-D) }\end{array}$ & \multirow{2}{*}{ Probability } \\
\hline \multirow{3}{*}{ Diameter } & $1 \mathrm{~mm}$ & 0.056098 & \multirow{2}{*}{0.8981} \\
\cline { 2 - 3 } & $2 \mathrm{~mm}$ & 0.045610 & \\
\cline { 2 - 3 } & $4 \mathrm{~mm}$ & 0.089390 & \multirow{2}{*}{0.3032} \\
\cline { 2 - 3 } & $1 \mathrm{~mm}$ & -0.01635 & \multirow{2}{*}{0.1838} \\
\cline { 2 - 3 } & $2 \mathrm{~mm}$ & -0.00095 & \\
\hline \multirow{3}{*}{ Width } & $4 \mathrm{~mm}$ & -0.07889 & \\
\cline { 2 - 3 } & $1 \mathrm{~mm}$ & -0.44585 & -0.23197 \\
\cline { 2 - 3 } & $2 \mathrm{~mm}$ & $4 \mathrm{~mm}$ &
\end{tabular}

\section{DENTATE DRIED CADAVER MANDIBLE PHASE}

The statistical analysis for this phase of the study is located in Appendix G.

On the basis of an ANOVA, the agreement between the intrasurgical (control) periodontal defect classifications and the classifications made from the standard x-rays and topographical maps by the panel of three evaluators was determined. This analysis is shown in Table 14. Evaluator A showed significant agreement with the intrasurgical classification for both the standard x-rays and topographical maps. Evaluator B had poor agreement between standard x-ray and intrasurgical classification, but the agreement was much better for the topographical map. Evaluator $\mathrm{C}$ did not have significant agreement with the control using either method. 
Table 14. Comparison between groups for significant agreement

\begin{tabular}{|c|c|c|c|c|c|c|}
\hline$*=\mathbf{p}<\mathbf{0 . 0 5}$ & $\begin{array}{c}\text { Evaluator } \\
\text { A } \\
\text { Std. Xray }\end{array}$ & $\begin{array}{c}\text { Evaluator } \\
\text { A } \\
\text { Topo Map }\end{array}$ & $\begin{array}{c}\text { Evaluator } \\
\text { B } \\
\text { Std. Xray }\end{array}$ & $\begin{array}{c}\text { Evaluator } \\
\text { B } \\
\text { Topo Map }\end{array}$ & $\begin{array}{c}\text { Evaluator } \\
\mathbf{C}\end{array}$ & $\begin{array}{c}\text { Std. Xray } \\
\text { C } \\
\text { Topo Map }\end{array}$ \\
\hline $\begin{array}{c}\text { Intrasurgical } \\
\text { (Control) }\end{array}$ & $*$ & $*$ & NSA & $*$ & NSA & NSA \\
\hline
\end{tabular}

* = Significant agreement between the groups $(\mathrm{p}<0.05)$

NSA $=$ No significant agreement between the groups

Table 15 shows the Kappa coefficients and p-values for the comparison of intrasurgical classification to standard x-ray. Table 16 shows the Kappa coefficients and pvalues for the comparison of intrasurgical classification to topographical map. For evaluator A, the agreement is significantly greater than that expected by chance for both procedures $(\mathrm{p}=0.01)$. While the greater percentage of agreements with the topographical map for evaluator A is encouraging, it is not significant ( $\mathrm{p}=0.11)$. Evaluator B showed improved agreement with the topographical map, and this improvement was significantly greater than chance $(\mathrm{p}=0.01)$. The greater percentage of agreement with the topographical map was significant $(\mathrm{p}=0.03)$. Evaluator C's small improvement for the topographical map was not significant.

Tables 15 and 16 confirm the improvement in percentage of perfect matches when using the topographical map versus the standard $\mathrm{x}$-ray. When the results for all three evaluators are pooled in Table 17, the combined percentage of perfect matches with the control is $34.4 \%$ for the standard $x$-ray and $48.7 \%$ for the topographical map. The difference between these two percentages is significant $(\mathrm{p}=0.01)$. 
Table 15. Comparison of Standard X-ray Value to Intrasurgical Value

\begin{tabular}{|c|c|c|c|}
\hline Evaluator & Perfect Matches & Kappa & p-value \\
\hline A & $26 / 63=46.0 \%$ & 0.1978 & 0.01 \\
\hline B & $18 / 63=23.6 \%$ & -0.0592 & 0.77 \\
\hline C & $21 / 63=33.3 \%$ & 0.0547 & 0.24 \\
\hline
\end{tabular}

Table 16. Comparison of Topographical Map Value to Intrasurgical Value

\begin{tabular}{|c|c|c|c|}
\hline Evaluator & Perfect Matches & Kappa & p-value \\
\hline A & $37 / 63=58.7 \%$ & 0.2930 & 0.01 \\
\hline B & $29 / 63=46.0 \%$ & 0.1978 & 0.01 \\
\hline C & $26 / 63=41.4 \%$ & 0.1120 & 0.09 \\
\hline
\end{tabular}

Table 17. Combined results for the three evaluators in Comparison to Intrasurgical Value

\begin{tabular}{|c|c|c|c|}
\hline $\begin{array}{c}\text { Perfect Matches for 2- } \\
\text { D -ray }\end{array}$ & $\begin{array}{c}\text { Perfect Matches with 3-D } \\
\text { rendering }\end{array}$ & $\begin{array}{c}\text { Difference } \\
\text { (3-D-2-D) }\end{array}$ & p-value \\
\hline $65 / 189=34.4 \%$ & $92 / 189=48.7 \%$ & $14.3 \%$ & 0.01 \\
\hline
\end{tabular}




\section{DISCUSSION}

\section{ORIENTATION PHASE}

In terms of image clarity, the panel of 34 evaluators preferred the computer-generated 3-D topographical map in 9 out of 12 (66\%) of the cases. Furthermore, the panel also preferred the computer-generated 3-D topographical map on the basis of image detail in 9 out of 12 cases (66\%). While statistical significance was found in only 5 of 12 and 6 of 12 of these cases, respectively, one can still draw the conclusion that the panel felt the 3-D renderings were an improvement in clarity and detail over the conventional radiographs. Possibly, the representation of gray scales in vertical height increased the amount of detail and clarity in the image. Perhaps many of the blurred or poorly imaged edges of structures in conventional 2-D radiographs are seen this way by our eyes due to our inability to see all gray scales that are present. As these gray scales are represented in a manner more easily seen by our eyes, the unclear portions of the 2-D x-ray may become more detailed and clear.

When the question of image quality is examined, the 3-D topographical map had statistically significantly greater image quality in only 2 out of 12 cases. Likewise, the 2-D conventional radiograph had statistically significant greater quality in 4 out of 12 cases. Incidentally, the cases in which the 3-D rendering had better quality, cases \#1 and \#4, were radiographs, which before enhancement were thought to be either over, or under-exposed. Therefore, one can assume that the use of the ImageIQ software may allow a conventional radiograph of lesser quality due to over or under-exposure to be more useful. Based on a sample size of two, this argument is not very solid. However, these results merely suggest a trend that could be confirmed with further study. On the other hand, the preference for the 2-D x-ray in 4 out of 12 cases may be explained by assuming that the panel was more 
familiar with looking at the conventional radiograph. Without any real idea of what a good quality image in the Lumen 3-D format would be, the panel might be more likely to find better overall quality in the 2-D radiograph. Having used 2-D radiographs for their entire clinical careers and having been taught the characteristics of quality radiography, the panel would definitely have an easier time distinguishing quality in the conventional format.

The results for confidence level and fatigue level may be explained in similar fashion. A higher confidence in the topographical map was statistically significant in only 2 out of 12 cases versus 1 out of 12 cases for the conventional radiograph. On the basis of fatigue level, a higher level of fatigue was statistically significant for the topographical map in 5 out of 12 cases versus just 1 out of 12 cases for the conventional radiograph. Since, this was the first experience this panel of evaluators had with the ImageIQ technology, the fact that their confidence level was low and their fatigue level was high is not without understanding. To the unfamiliar and untrained observer, any new process of imaging dental structures would be more of a burden. Most observers would likely be more confident and less fatigued when looking at a type of image that he or she was both trained with and had more clinical experience using. However, this lack of familiarity does not prevent the observer from discerning such parameters as detail and clarity. As mentioned above, the computergenerated 3-D topographical map proved superior to the conventional x-ray with respect to these variables. Therefore, this study has rejected the null hypothesis stating that no difference exists between the 2-D radiograph and 3-D rendering on the basis of image detail, clarity, overall quality, confidence and fatigue levels. Further study on the application of this software is warranted. 


\section{EDENTULOUS DRIED CADAVER MANDIBLE PHASE}

\section{ANALYSIS OF DIAMETER MEASUREMENTS}

Irrespective of the x-ray beam variables used: 12 impulses, 90 degrees; 12 impulses, +10 degrees; 12 impulses, +20 degrees; 8 impulses, 90 degrees; or 18 impulses, 90 degrees, the ANOVA test found that neither the conventional 2-D radiograph nor the 3-D computer generated topographical map showed any statistically significant differences in determining simulated defect diameter for the three defect locations in the mandible: anterior, left buccal, and right buccal. Most importantly, when comparing the measurement differences between the 2-D x-ray and 3-D rendering, ANOVA found these differences to be non-significant. Therefore, on the basis of bone density/quality, the null hypothesis is not rejected, and no significant difference seems to be apparent between imaging performed in D2 bone of the anterior mandible and D3 bone of the posterior mandible. One explanation of this result could be that dried cadaver bone does not exhibit the same density characteristics of living human bone. The age of the cadaver mandible may have some effect on the different density levels of the bone. Furthermore, the diameter measurements were taken of simulated defects drilled into cortical bone on the lateral aspect of the mandibular body. Since there is no thickness of cortical bone between the defect and the x-ray beam, bone density may have had little effect on the diameter measurements.

Irrespective of the x-ray beam variables used: 12 impulses, 90 degrees; 12 impulses, +10 degrees; 12 impulses, +20 degrees; 8 impulses, 90 degrees; or 18 impulses, 90 degrees, the ANOVA test found that the conventional 2-D radiograph showed significant differences in determining simulated defect diameter for the three defect sizes: $1 \mathrm{~mm}, 2 \mathrm{~mm}, 4 \mathrm{~mm}$. The computer generated topographical rendering also showed significant differences in 
determining simulated defect diameter for the three defect sizes mentioned. Therefore, both types of imaging were able to accurately distinguish between different defect diameters. Most importantly, when comparing the measurement differences between the 2-D x-ray and 3-D rendering, ANOVA found these differences to be non-significant. Furthermore, no statistical difference was noted in either method's ability to more accurately distinguish between any one of the defect sizes. Therefore, the null hypothesis cannot be rejected. No matter what the $\mathrm{x}$-ray beam variable is set to, the measurement of defect diameter is not significantly different for either type of imaging no matter what size the defect might be. As mentioned before, these simulated defects were made in the cortical bone on the lateral aspect of the mandible. The contrast between the defects and the surrounding cortical bone was high making the determination at both small and large diameters much easier.

On the basis of x-ray beam angulation, the null hypothesis is not rejected as no significant difference was seen between 2-D radiographs and 3-D renderings when the beam angulation was changed. Therefore, the representation of gray scales in a vertical manner did not distort as the beam angulation was changed. Any changes that occurred in the 2-D radiograph were accurately imaged with the 3-D rendering. From these findings, the deliberate change of beam angulation that is commonly used in dentistry in specialties such as endodontics and prosthodontics would be tolerated by the 3-D rendering. In addition, the common practice of changing beam angulations in periodontics to get a slightly difference perspective on a periodontal defect would be tolerated by the ImageIQ 3-D rendering. Furthermore, any change in measurement in this study would have only been the effect of overlapping of the defects. The distance between the defects must have been enough to prevent this scenario as no measurement differences due to overlapping were seen. Possibly, 
the results found could have been different if the symmetrical, circular defects were replaced by noncircular, asymmetrical simulated defects. The production of this type of defect would have been extremely difficult.

With respect to x-ray beam exposure time, no statistically significant differences existed between the times studied: 8,12 and 18 impulses. Therefore, the null hypothesis is not rejected. A possible explanation could be that fewer than 8 impulses and more than 18 impulses should have been used. While preliminary testing showed these settings to produce visually different radiographic densities, the process of digitization may have reduced the effect of changing exposure time. A study conducted by Svenson, et.al. investigated the effects of exposure time on caries diagnosis. This study used a wider range of exposure times: 14.4 impulses to multiple exposures resulting in over 4600 impulses. ${ }^{52}$ However, the results of this study and those of Svenson, et. al. are similar in that Svenson found only a small effect of exposure time on the accuracy of caries diagnosis. They found exposure time to have a $25 \%$ effect while the other $75 \%$ was attributed to evaluator performance. ${ }^{52}$ Currently, no other studies exist to evaluate the effect of exposure time on the measurement of periodontal defect dimension. Another possible explanation could have been the fact that the symmetrically shaped simulated defects contrasted enough with the surrounding bone that variation in exposure time at such a small magnitude had little effect on the imaging of the defects. Therefore, this study has shown that both the conventional 2-D radiograph and the computer-generated 3-D topographical rendering tolerate a small change in radiographic density that could possibly be due to operator error in setting exposure time.

\section{ANALYSIS OF WIDTH AND LENGTH MEASUREMENTS}

Irrespective of the x-ray beam variables used: 12 impulses, 90 degrees; 12 impulses, +10 degrees; 12 impulses, +20 degrees; 8 impulses, 90 degrees; or 18 impulses, 90 degrees, 
the ANOVA test found that the conventional 2-D radiograph showed no statistically significant differences in determining simulated defect width and length for the three defect locations in the mandible: anterior, left buccal, and right buccal. The computer generated topographical rendering also showed no significant differences in determining simulated defect width and length for the three defect locations mentioned using all $\mathrm{x}$-ray beam variables. Most importantly, when comparing the measurement differences between the 2-D x-ray and 3-D rendering, ANOVA found these differences to be non-significant. Therefore, on the basis of bone density/quality, no significant difference seems to be apparent between imaging performed in D2 bone of the anterior mandible and D3 bone of the posterior mandible. The null hypothesis cannot be rejected. One explanation of this result could be that dried cadaver bone does not exhibit the same density characteristics of living human bone. The age of the cadaver mandible may have some effect on the different density levels of the bone. Some amount of bone could have deteriorated over time or through processing and sterilization. Also, the effect of drilling the simulated defects intracortically into more delicate trabecular bone may have been traumatic to the dried mandibles. This brittle bone may have fractured more than was expected reducing the overall density differences that should have existed.

Irrespective of the x-ray beam variables used: 12 impulses, 90 degrees; 12 impulses, +10 degrees; 12 impulses, +20 degrees; 8 impulses, 90 degrees; or 18 impulses, 90 degrees, the ANOVA test found that the conventional 2-D radiograph showed significant differences in determining simulated defect width for the three defect sizes: $1 \mathrm{~mm}, 2 \mathrm{~mm}, 4 \mathrm{~mm}$. The computer generated topographical rendering also showed significant differences in determining simulated defect width for the three defect sizes mentioned. Most importantly, 
when comparing the measurement differences between the 2-D x-ray and 3-D rendering, ANOVA found these differences to be non-significant. Furthermore, no statistical difference was noted in either method's ability to more accurately distinguish between any one of the defect widths. Therefore, if the defect was present in the 2-D conventional radiograph, the computer generated rendering was just as successful as imaging the defect's width.

With respect to defect length, the conventional 2-D radiograph showed no statistically significant differences for the three defect sizes used. The computer generated topographical rendering also showed no significant differences in determining simulated defect length for the three defect sizes used. Most importantly, when comparing the width and length measurement differences between the 2-D x-ray and 3-D rendering, ANOVA found the differences in both width and length to be non-significant. Therefore, no matter what the $\mathrm{x}$-ray beam variable is set to, the measurement of defect width and length is not significantly different for either type of imaging no matter what size the defect might be. The null hypothesis is not rejected based on these statements.

On the basis of $\mathrm{x}$-ray beam angulation, the null hypothesis is not rejected as no significant difference was seen between 2-D radiographs and 3-D renderings when the beam angulation was changed. As with the diameter measurements, width and length measurements in the 3-D rendering were not affected by beam angulation change. A possible explanation could be due to the fact that the simulated defects were cylindrical in shape and placed intracortically in the mandibular body. Therefore the x-ray beam passed perpendicular to the simulated defects. The horizontal rotation of the beam would have occurred around the long axis of the cylindrical defects. As the beam angulation was changed in the horizontal dimension, a symmetrical, cylindrically shaped defect would show 
little effect of a change in beam angle. Any change in measurement would have only been the effect of overlapping of the defects. The distance between the defects must have been enough to prevent this scenario as no measurement differences due to overlapping were seen. Therefore, the production of noncircular, asymmetrical simulated defects may have been a better choice for this portion of the study. The production of this type of defect would have been extremely difficult.

With respect to x-ray beam exposure time, no statistically significant differences existed between the times studied: 8, 12 and 18 impulses. Therefore, the null hypothesis cannot be rejected. The explanation for this finding with regard to simulated defect width and length would be the same as previously discussed for defect diameter measurements Therefore, based on the discussion of the results just presented, the following null hypotheses could not be rejected. No difference exists in the discriminability of periodontal defects between LumeniIQ’s ImageIQ 3-D topographically rendered radiographs and traditional digitized radiographs. No difference exists in the quality of ImageIQ's 3-D topographically rendered radiographs when exposure time is varied. No difference exists in the quality of ImageIQ's 3-D topographically rendered radiographs when beam angulation is varied. No difference exists in the quality of ImageIQ's 3-D topographically rendered radiographs when imaged from higher density/quality anterior mandibular bone and lower density/quality posterior mandibular bone. Hence, the computer generated topographical rendering is neither any worse nor any better than conventional 2-D radiographs at accurately imaging simulated periodontal defects. 


\section{DENTATE DRIED CADAVER MANDIBLE PHASE}

Evaluator A had a higher percentage of agreement with the control with both the standard x-ray (46.0\%) and topographical map (58.7\%). This may be related to the fact that evaluator A was a periodontist and had the most years of clinical experience. Evaluator B had poor agreement using the standard $\mathrm{x}$-ray (28.6\%) and better agreement using the topographical map (46.0\%). Evaluator B was also a periodontist but had fewer years of clinical experience than evaluator A. Evaluator C did not have significant agreement with the intrasurgical control using either the standard x-ray (33.3\%) or the topographical map (41.4\%). Incidentally, evaluator $\mathrm{C}$ was an oral pathologist. This evaluator had the least experience with diagnosis and classification of periodontal defects.

Despite the efforts of the principal investigator to standardize the evaluators and refresh their understanding of periodontal defect classification, the difference in clinical experience and clinical background may have affected the results of this phase of the study. The use of more periodontists to evaluate and classify the defects in the 2-D and 3-D images may have produced more consistent results. Unfortunately, a larger number of periodontists was not available for this study. This consideration should be made for future studies of this nature.

Despite the lack of more uniform periodontal clinical experience with the panel used in this study, encouraging results were found when using the 3-D topographical rendering to classify periodontal defects. When the data for all evaluators was pooled, better agreement with the intrasurgical control was seen when using the topographical map (48.7\%) vs. the standard x-ray (34.4.0\%). The difference between these two percentages (14.3\%) is significant $(\mathrm{p}=0.01)$. Therefore, the analysis still shows that statistical evidence exists for 
improved detection and classification of periodontal defects when using the computer generated topographical map. Perhaps the representation of gray scales in a vertical manner provides additional information to lead to a more accurate classification of periodontal defects.

The gold standard for in-depth description of periodontal defect classification is still intrasurgical measurement. ${ }^{2,22,23,2,4,25,26}$ Obviously, this method is the most invasive, costly, and time-consuming. It appears that some limitations that exist for 2-D conventional $\mathrm{x}$-rays exist for the ImageIQ rendering as well. The presence of thick buccal and lingual cortical plates tends to obscure the defect. The presence of this thick bone also affects the quality of the rendering. However, some level of improvement over the conventional radiograph has been found. Pepelassi, et al. found that conventional periapical radiographs detect only $61.85 \%$ of periodontal defects. ${ }^{27}$ The dentate mandible phase of this study has shown that computer generated topographical mapping of conventional 2-D radiographs can improve the accuracy of defect classification by $14.3 \%$ (48.7\% versus $34.4 \%$ ). With further improvement of the technology and its method of use, the computer generated topographical map may prevent the need for some periodontal surgical procedures. Therefore, this study has rejected the null hypothesis stating that no difference exists between conventional 2-D radiographs and ImageIQ's 3-D topographical renderings in the determination of existing periodontal defect classification. 


\section{CHAPTER V \\ SUMMARY, CONCLUSIONS, RECOMMENDATIONS}

\section{SUMMARY}

The purpose of this study was fourfold. First, the study was to determine the level of interest in 3-D radiographic enhancement through an orientation phase. Second, the study attempted to compare a new 3-D software platform, LumenIQ’s ImageIQ, to conventional 2$\mathrm{D}$ radiographs in terms of its ability to aid the clinician in accurately classifying periodontal defects. Third, the study was to evaluate the ability of the ImageIQ software to accurately image a simulated periodontal defect of known dimension when compared to conventional 2D radiographs. Fourth, the hope was to provide further information on the effect of variation in exposure time, beam angulation, and mandibular bone density/quality on the quality of the ImageIQ 3-D topographically rendered images. If these questions could be answered positively, ImageIQ’s usefulness as a diagnostic tool for periodontal defects could be determined. Since orthodontists routinely deal with periodontal defects, enhancement of the detection and diagnosis of these defects would be significant.

This investigation included an orientation/ phase to determine the level of interest in 3-D radiographic enhancement. A panel of 34 evaluators of varied dental background was shown 12 cases. These cases consisted of conventional radiographs and their ImageIQ 3-D topographical renderings of various anatomical and pathological structures. The panel was asked questions concerning their ability to detect such landmarks and pathology. They were asked to evaluate the quality, clarity, and detail, as well as their perceived level of confidence 
and fatigue in looking at the images of both the conventional 2-D and the ImageIQ 3-D topographical image.

The second phase of the study involved the placement of simulated periodontal defects of specific dimension into edentulous dried human cadaver mandibles. These mandibles were then radiographed. First, x-ray beam angulation was kept constant at $90^{\circ}$, and exposure time was varied between 8, 12, and 18 impulses. Next, exposure time was kept constant at 12 impulses, and beam angulation was varied between $90^{\circ}$ (perpendicular) and $10^{\circ}$ and $20^{\circ}$ to the perpendicular in the horizontal plane. The conventional radiographs were rendered with the ImageIQ software. The conventional radiographs and the 3-D topographical renderings were then evaluated. The defects on each radiograph were measured. The ability of the ImageIQ 3-D rendering to accurately image the defect was compared to that of the conventional radiograph. In addition, the effect of variation in exposure time and beam angulation on the defect detection was also evaluated.

The third and final phase of the study involved the evaluation of dentate dried human cadaver mandibles with existing periodontal defects. These defects were detected and classified directly and were then radiographed at $90^{\circ}$ and at 12 impulses. The conventional 2-D radiographs were rendered using ImageIQ. A panel of three evaluators consisting of two periodontists and one oral pathologist were shown a randomized compilation of conventional radiographs and 3-D topographical images. The panel then classified the periodontal defects in these images using the 1, 2, or 3-walled classification system. This phase attempted to determine the ability of the evaluator to accurately classify the defects with the topographical rendering compared to the conventional radiograph. 


\section{CONCLUSIONS}

The following conclusions were made.

1. Significant difference exists in the levels of image clarity, image detail, overall image quality, and observer confidence and fatigue levels between LumenIQ’s ImageIQ 3-D topographical rendering and the traditional digitized radiographs.

2. No significant difference exists between conventional 2-D radiographs and ImageIQ’s 3-D topographical renderings when x-ray beam exposure time is varied within a small range.

3. No significant difference exists between conventional 2-D radiographs and ImageIQ’s 3-D topographical renderings when $\mathrm{x}$-ray beam angulation is varied up to $20^{\circ}$ from the horizontal.

4. No significant difference exists between conventional 2-D radiographs and ImageIQ’s 3-D topographical renderings when defects are imaged in different bone densities of the anterior and posterior mandible.

5. No significant difference exists between conventional 2-D radiographs and ImageIQ’s 3-D topographical renderings when imaging defects with widths of $1 \mathrm{~mm}, 2 \mathrm{~mm}$, and $4 \mathrm{~mm}$.

6. Significant difference exists between conventional 2-D radiographs and ImageIQ’s 3-D topographical rendering in the determination of existing periodontal defects classification. 
7. Significant difference exists in the discriminability of periodontal defects between LumeniIQ’s ImageIQ 3-D topographically rendered radiographs and traditional digitized radiographs.

\section{RECOMMENDATIONS}

The following recommendations were made.

1. More intensive familiarization of any panel of evaluators with this new technology should be accomplished prior to undertaking a similar mode of study.

2. Sample size should be increased for further evaluation of dental practitioner's preference for the computer generated topographical rendering.

3. Sample size should be increased by increasing the number of cadaver mandibles used in the simulated periodontal defect portion of this study.

4. Future simulated periodontal defect studies should investigate the possibility of producing asymmetrical simulated defects, which would more closely represent naturally occurring defects.

5. Future evaluation of the effect on exposure time should use comparatively lower and higher exposure times than those used in this study.

6. The inclusion of more evaluators in the determination of existing periodontal defect classification would strengthen the results of this study.

7. An In Vivo evaluation of this software's ability to aid in the detection and classification of periodontal defects should be explored. 


\section{REFERENCE LIST}

1. Benn DK, Eickholz P, Kim TS, Staehle HJ. Validity of radiographic measurement of interproximal bone loss. Oral Surg Oral Med Oral Pathol 1998;85:99-106.

2. Theilage J. An evaluation of the reliability of radiographs in the measurement of bone loss in periodontal disease. J Periodontol 1960;31:143-153.

3. Grondahl H-G. Digital radiology in dental diagnosis: a critical view.

Dentomaxillofacial Radiology 1992;21:198-202.

4. Carranza FA, Newman MG. Clinical Periodontology, $8^{\text {th }}$ Edition. Saunders. Philadelphia 1996.

5. Goldman HM, Cohen DW. The intrabony pocket: Classification and treatment. J Periodontol 1958;29:272.

6. Lindhe J, Liljenberg B, Listgarten MA. Some microbiological and histopathological features of periodontal disease in man. J Periodontol 1980;51:264.

7. Lopez-Otero R, Parodi RJ, Ubios AM, et al. Histologic and histomeric study of bone resorption after tooth movement in rats. J Periodont Res 1973;8:327.

8. Lindhe J, Svanberg G. Influence of trauma from occlusion on progression of experimental periodontitis in beagle dogs. J Clin Periodontol 1974;1:3.

9. Loe H, Anerud A, Boysen H, Morrison E. Natural history of periodontal disease in man. Rapid, moderate and no loss of attachment in Sri Lankan laborers 14 to 46 years of age. J Clin Periodontol 1986;13:431.

10. Cirelli CC, Cirelli JA, Martins JC, Lia RCC, Rossa C, Marcantonio E. Orthodontic movement of teeth with intraosseous defects: Histologic and histometric study in dogs. Am J Orthod Dentofacial Orthop 2003;123:666-75.

11. Cortellini P, Pini Prato G, Tonetti MS. Periodontal regeneration of human infrabony defects. II. Reentry procedured and bony measures. J Periodontol 1993;64:261-8.

12. Kessler M. Interrelationships between orthodontics and periodontics. Am J Othod 1976;70:154-72.

13. Polson A, Caton J, Polson AP, Nyman S, Novak J, Reed B. Periodontal response after tooth movement into intrabony defects. J Periodontol 1984;55:197-202.

14. Geraci TF, Nevins M, Crossetti HW, Drizen K, Ruben MP. Reattachment of the periodontium after tooth movement into an osseous defect in a monkey. Part I. Int J 
Periodontics Restorative Dent 1990;10:185-207.

15. Brown S. The effect of orthodontic therapy on certain types of periodontal defects. Iclinical findings. J Periodontol 1973;44:742-56.

16. Kazandjian G, Scopp IW, Stahl S. Combined orthodontic-periodontal treatment of an infrabony defect. A case report. J Periodontol 1979;50:479-82.

17. Vanarsdall RL Jr. Periodontal/orthodontic interrelationships. In: Graber TM, Vanarsdall RL Jr, editors. Orthodontics current principles and techniques. St. Louis: Mosby; 1994. 712-49 $2^{\text {nd }}$ ed.

18. Lindskog-Stokland B, Wennstrom JL, Nyman S, Thilander B. Orthodontic tooth movement into edentulous areas with reduced bon height. An experimental study in the dog. Eur J Orthod 1993;15:89-96.

19. Ericcson I, Thilander B, Lindhe J, Okamoto $\mathrm{H}$. The effect of orthodontic tilting movements on the periodontal tissues of infected and non-infected dentitions in dogs. J Clin Periodontol 1977;4:278-93.

20. Proffit WR, Fields HW. Contemporary Orthodontics. Mosby. St. Louis 2000.

21. Kokich VG, Mathews DP. Managing Treatment for the Orthodontic Patient with Periodontal Problems. Seminars in Orthod. 1997;3:21-38.

22. Papapanou PN, Wennstrom JL. The angular bony defect as indicator of further alveolar bone loss. J Clin Periodontol 1991;18:317-22.28.

23. Suomi JD, Plumbo J, Barbano JP. A comparative study of radiographs and pocket measurement in periodontal disease evaluation. J Periodontol 1968;39:311-5.

24. Shrout MK, Hildebolt CF, Vannier MW. The effect of alignment errors on bitewingbased bone loss measurements. J Clin Periodontol 1991;18:708-12.

25. Akesson L, Hakansson J, Rohlin M. Comparison of panoramic and intraoral radiography and pocket probing for the measurement of marginal bone level. J Clin Periodontol 1992;19:326-32.

26. Tonetti MS, Pini-Prato G, Williams RC, Cortellini P. Periodontal regeneration of human infrabony defects. III. Diagnostic strategies to detect bone gain. J Periodontol 1993;64:269-77.

27. Eickholz P, Benn DK, Staehle HJ. Radiographic evaluation of bone regeneration following periodontal surgery with or without expanded polytetrafluoroethylene barriers. J Periodontol 1996;67:378-85. 
28. Pepelassi EA, Diamanti-Kipioti A, Tsiklakis K. Radiographic detection and assessment of the periodontal endosseous defects. J Clin Periodontol 2000;27:22430.

29. Stoner JE. An investigation into the accuracy of measurements made on radiographs of the alveolar crests of dried mandibles. J Periodontol 1972;43:699-701.

30. Wengraf A. Radiologically occult bone cavities-an experimental study. Br Dent J 1964;117:532-36.

31. Eickholz P, Hassfeld S, Staehle HJ, Von Bethlenfalvy E, Wolf B. Reliability of assessing interproximal bone loss by digital radiography: intrabony defects. J Clin Periodontol 2001;28:869-78.

32. Adelson EH. Lightness perception and lightness illusions. In The New Cognitive Neurosciences, $2^{\text {nd }}$ Edition. Gazzaniga H, ed.Cambridge, Ma. MIT Press. 2000;339351.

33. Chang KM, Harasty L, Janal M, Khocht A. Comparison of direct digital and conventional intraoral radiographs in detecting alveolar bone loss. J Am Dent Assoc 2003;134:1468-75.

34. Holthuis A, Lavelle CLB, Putnins E. Detection of three-walled infrabony defects by subtraction radiography. Oral Surg Oral Med Oral Pathol 1988;65:102-8.

35. Grondahl HG, Grondahl K. Subraction radiography for the diagnosis of periodontal lesions. Oral Surg Oral Med Oral Pathol 1983;55:208-13.

36. Ortman LF, Dunford R, McHenry K, Hausmann E. Subtraction radiography and computer assisted densitometric analyses of standard radiographs. A comparison with ${ }^{125}$ I absorptiometry. J Periodont Res 1985;20:644-51.

37. Westra D. History of Tomography. In Berrett A, Brunner S, Valvassori GE. Modern Thin-Section Tomography. Springfield, Ill. 1973. Charles C Thomas Publisher, pp.317.

38. Rosenberg HM. Laminagraphy: Methods and Application in Oral Diagnosis. J Am Dent Assoc 1967;74:88-96.

39. Stalker WH, Cutright DE, Goodwin DW. Tomography of the alveolar process. Oral Surg Oral Med Oral Pathol 1980;49:184-6.

40. Krohmer, JS. Patient Dose Distributions During Hypoclodal Tomography. Radiat. Physics 1972;103:447-450.

41. Antoku GW, Kihara T, Russell WJ, Beach D. Radiation doses to critical organs from 
dental radiography. Oral Surg 1976;41:251-260.

42. Aranyarachkul P, Caruso J, Gantes B, Schulz E, Riggs M, Dus I, Yamada JM, Crigger M. Bone density assessments of dental implant sites: 2. Quantitative conebeam computerized tomography. Int J Oral Maxillofac Implants. 2005;20:416-424.

43. Marmulla R, Wortche R, Muhling J, Hassfeld S. Geometric accuracy of the NewTom 9000 Cone Beam CT. Dentomaxillofacial Rad. 2005;34:28-31.

44. Hamada Y, Kondoh T, Noguchi K, Iino M, Isono H, Ishii H, Mishima A, Kobayashi $\mathrm{K}$, Seto K. Application of limited cone beam computed tomography to clinical Assessment of alveolar bone grafting: a preliminary report. Cleft Palate Craniofac J. 2005;42:128-137.

45. Mishima A, Kobayashi K, Yamamoto A, Kimura Y, Tanaka M. The calculation of patient radiation dose in the dental CT (PSR 9000). Tsurumi Univ Dent J. 2003;29:7-12.

46. Allen K, Hausman E, Tibbetts. Effect of Angulation on Radiographic Periodontal Ligament Space Width. J Periodontol 1992;63:114-117.

47. Hildebolt CF, Potter BJ, Shrout MK, Weaver, J. Spatial Resolution and Angular Alignment Tolerance in Radiometric Analysis of Alveolar Bone Change. J Periodontol 1996;67:41-5.

48. Shrout MK, Weaver J, Potter BJ, Hildebolt CF. Spatial Resolution and Angular Alignment Tolerance in Radiometric Analysis of Alveolar Bone Changes. J Periodontol 1996;67:41-45.

49. Razmus TF, Williamson GF. Current oral and maxillofacial imaging. Saunders. Philadelphia 1996.

50. Hildebolt CF, Fletcher G, Yokoyama-Crothers N, Conover GL, Vannier MW. A comparison of the response of storage phosphor and film radiography to small variations in x-ray exposure. Dentomaxillofacial Radiology 1997;26:147-51.

51. Welander U, Nelvig P, Tronje G, et al. Basic technical properties of a system for direct acquisition of digital intraoral radiographs. Oral Surg Oral Med Oral Pathol 1993;75:506-16.

52. Svenson B, Welander U, Anneroth G, Soderfeldt B. Exposure parameters and their effects on diagnostic accuracy. Oral Surg Oral Med Oral Pathol 1994;78:544-50.

53. Morris HF, Ochi S, Orenstein IH, Truhlar RS. Distribution of Bone Quality in Patients Receiving Endosseous Dental Implants. J Oral Maxillofac Surg 1997;55:3845. 
54. Lekholm U, Zarb G. Chicago: Quintessence 1985:199-209.

55. Bidez MW, Misch CE, Qu Z. Mechanical Properties of Trabecular Bone in the Human Mandible: Implications for Dental Implant Treatment Planning and Surgical Placement. J Oral Maxillofac Surg 1999;57:700-706.

56. Cohn SH, Kalend AM, Meek AB, Maryanski M, Reinstein LM, Schidloovsky G, Washington AC, Wielopolski L. Polyacrylamide-based phantoms as tissue substitutes in experimental radiation physics. Med Phys 1985;12:788-92.

57. Ott p. Zur Rontgenstrahlenbehandlung oberflachlich gelagerter Tumoren. Strahlentherapie 1937;59:189-223.

58. Anderson SW, Lanzl LH, Rollins M, Spira J. An instrumented phantom system for analog computation of treatment plans. Am J Roentgenol 1962;87:185-195.

59. Mouyen F, Benz C, Sonnabend E, Lodter P. Presentation and physical evaluation of RadioVisioGraphy. Oral Surg Oral Med Oral Pathol 1989;68:238-42.

60. Lucaino J, Withrow K, Razmus T, Wearden S, Crout R. Digital Radiography: Awareness and Usage Among Practicing West Virginia Dentists.

61. Digital radiography in dentistry: What should it do for you? www.cda.org/member/pubs/journal/jour1299/digital.html.

62. Gamma correction explained. www.cgsd.com/papers/gamma_intro.html

63. LumenIQ information homepage. www.lumenIQ.com

64. Blake SA, Klein RMF, Hirschmann PN, Nattress BR. Evaluation of X-ray beam angulation for successful twin canal identification in mandibular incisors. Int Endod J 1997;30:58-63.

65. Chandler NP, Herbison P, Love RM, Naoum HJ. Effect of X-ray beam angulation and intraradicular contrast medium on radiographic interpretation of lower first molar root canal anatomy. Int Endod J 2003;36:12-19.

66. Ellingsen MA, Harrington GW, Hollender LG. Radiovisiography versus conventional radiography for detection of small instruments in endodontic length determination: Part I. In vitro evaluation. J Endod 1995;21:326-331.

67. Ellingsen MA, Hollender LG, Harrington GW. Radiovisiography versus conventional radiography for detection of small instruments in endodontic length determination: Part II. In vivo evaluation. J Endod 1995;21:516-20. 
68. Chai-U-Dom O, Ludlow JB, Tyndall DA, Webber RL. Detection of simulated periodontal bone gain by digital subtraction radiography with tuned-aperture computed tomography. The effect of angular disparity. Dentomaxillofacial Radiol. 2001;30:72-97.

69. Bassagnani MJ, Bubash-Faust L, Ciambotti J, Moran R, McIlhenny J. Conversion of teaching file cases from film to digital format: a comparison between use of diagnostic-quality digitizer and use of a flatbed scanner with transparency adapter. Acad Radiol 2003;10:536-42.

70. Ruess, L, Uyehara CFT, Shiels KC, Cho KH, O’Conner SC, Whitton RK, Person DA. Digitizing pediatric chest radiographs: comparison of low-cost, commercial offthe-shelf technologies. Pediatr Radiol 2001;31:841-847.

71. Chen SK, Hollender L. Digitizing of radiographs with a flatbed scanner. J Dent 1995;23:203-208.

72. Janhom A, van Ginkel FC, van Amerongen JP, van der Stelt PF. Scanning resolution and the detection of approximal caries. Dentomaxillofac Radiol 2001;30:166-71.

73. Corl FM, Garland MR, Lawler LP, Fishman EK. A five-step approach to digital image manipulation for the radiologist. Radiographics 2002;22:981-92.

74. Halazonetis DJ. At what resolution should I scan cephalometric radiographs? Am J Orthod Dentofacial Orthop 2004;125:188-9.

75. Gurdal P, Hildebolt CF, Akdeniz BG. The effects of different image file formats and image-analysis software programs on dental radiometric digital evaluations. Dentomaxillofac Radiol 2001;30:50-5. 


\section{APPENDIX A}

\section{IRB APPROVAL FORMS}




\section{Application for Exemption}

Approval from the IRB staff must be received prior to beginning the research described below. Please type all responses and submit this form with original signatures. All investigators must complete Ethics Training before an approval will be granted.

1. Title of study:

$$
\begin{aligned}
& \text { SENSITIVITY COMPARISON EVALUATION OF COMPUTER-GENERATED } \\
& \text { THREE DIMENSIONAL SURFACE TOPOGRAPHY TO CONVENTIONAL } \\
& \text { MAXILLOFACIAL RADIOGRAPHIC IMAGERY: } 12 \text { Case Histories }
\end{aligned}
$$

2. Investigators (list all investigators, principal investigator first; attach additional sheets if necessary):

Name

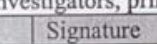

Dept/College

Address

\begin{tabular}{|l|l|l|}
\hline Mame & Dignature & Dept. of Orthodontics \\
\hline Peter Ngan, DMD & $\begin{array}{l}\text { Dept. of Orthodontics } \\
\text { Dept. of Periodontics }\end{array}$ \\
\hline Harold Reed, DDS, MS & Dept. Of Radiology \\
\hline Tom Razmus, DDS,MS & &
\end{tabular}

Tom Razmus, DDS,MS

Name or initials

Michael Hazey, DDS

Peter Ngan, DMD

Harold Reed, DDS, MS

Tom Razmus, DDS,MS

( -1$)$

213 Stonegate Circle $304-598-0185$

Morgantown, WV

26505

PO Box 9480

293-3222

PO Box $9401 \quad 293-5642$

3. Estimated period of project or of human subject involvement: Starting date:

4. Reason for conducting research

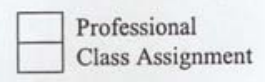

Dissertation

Other

Ethics Training $^{1}$ HIPAA Training ${ }^{2}$
Class Assignment

5. Source of funding (if applicable) N/A

6. Number of projected subjects 12 Number of projected records or data files

\begin{tabular}{l|l}
\hline Yes & Yes \\
\hline
\end{tabular}

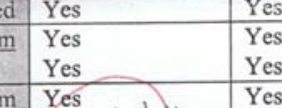

Yes

$\mathrm{X}$ Thesis

7. This research involves (check all that apply—see attached "Exempt Research" page):

X a Collection or study of existing data, documents, records or specimens, recorded without identifiers.

c Educational tests (cognitive, diagnostic, aptitude, achievement)

d Observation of public behavior

e Surveys, interviews or hand-outs for subjects over 18 (use age ranges, not actual age, for demographic information):

$\square$ Mail $\square$ Telephone $\square$ Person-to-person

APPROVED

JUN 302004

065204

WW SCHOOL OF DENTISTRY
OFFCE OF RESEARCH

f A Any possibility of identifying a subject (discuss in cover letter)

g The possibility that the subject's responses or conduct (if they became public) may place the subject at risk of criminal or civil liability or be damaging to the subject's financial standing or employability

Sensitive aspects of personal behavior (for example: illegal conduct, drug use, sexual behavior or use of alcohol) Investigator's participation in activities being observed

Only surveys or interviews of elected or appointed public officials or candidates for public office

Audiotaping

Children under age 18 (see Chapter II of the Guidelines)

Note: Interviews and surveys with children are never exempt.

$\mathrm{m}$ Food tasting and evaluation

n Research and demonstration projects

o Access to protected health information (PHI) (See HIPAA requirements: http://www.wvu.edu/ $\sim \mathrm{rc} / \mathrm{irb} / \mathrm{index}$.htm)

8. Goal of research 
Provide evidence that ImageIQ benefits dental practicioners in reading of dental and maxillofacial radiographs.

- Provide an assessment or estimate of the scope of practice where ImageIQ is clinically or diagnostically relevant or applicable to the dental community, and to which specific clinical and diagnostic disciplines it can be applied.

- Provide understanding of optimal visualization parameters within the dental community practice.

Revised Dec 2003

9. Explanation of procedures involved in research

Retrospective evaluation of 12 dental and maxillofacial pathology cases including case histories and radiographs.

Original radiographs will be rendered using LumenIQ's ImageIQ software providing a 3D topographical representation.

The evaluators will review the case histories and answer questions about the original and rendered radiographs to compare the diagnostic quality and usefulness of each.

The data will show whether the evaluators feel the ImageIQ renderings increased their diagnostic ability to detect pathologies.

The identity of the 12 dental and maxillofacial pathology cases will be kept as confidential as legally possible.

10. Explanation of known risks to human subjects

N/A

11. Explanation of how records will be kept

Records will be kept by number identification in a locked box.

A cover letter addressed to respondents must accompany any survey or questionnaire. The cover letter must be on the investigator's

WVU departmental letterhead and must include the following:

1 a statement that the project is research being conducted in partial fulfillment of the requirements for a course, master's thesis, dissertation, etc.

2 purpose of study

3 a statement that subjects' responses will be kept anonymous or confidential (explain extent of confidentiality if subjects' names are requested)

4 if audiotaping, a statement that subject is being audiotaped (explain how tapes will be stored or disposed of during and after the study)

5 a statement that subjects do not have to answer every question

6 a statement that subject's class standing, grades, or job status (or status on an athletic team, if applicable) will not be affected by refusal to participate or by withdrawal from the study

7 a statement that participation is voluntary

Attachments:

questionnaire/survey to be used

telephone text (including introductory remarks as in a cover letter-see above)

cover letter

permission from external institution, on their letterhead (if applicable) 
I have reviewed the above infermation and recommend this study for exemption.

1) 10 ?

$\frac{M}{\text { Dean or Director }}\left\{\begin{array}{l}6-30 \text { Jy } \\ \text { Department Chair }\end{array}\right.$

Faculty Advisor

Dean or Director

Department Chair 


\section{Application for Exemption}

Approval from the IRB staff must be received prior to beginning the research described below. Please type all responses and submit this form with original signatures. All investigators must complete Ethics Training before an approval will be granted.

1. Title of study:

\section{SENSITIVITY COMPARISON EVALUATION OF COMPUTER-GENERATED THREE DIMENSIONAL SURFACE TOPOGRAPHY TO CONVENTIONAL MAXILLOFACIAL RADIOGRAPHIC IMAGERY: 125 Mandibles}

2. Investigators (list all investigators, principal investigator first; attach additional sheets if necessary):

\begin{tabular}{|c|c|c|c|c|}
\hline Name & Signature & Dept/College & Address & Tel No \\
\hline Michael Hazey, DDS & II) & Dept. of Orthodontics & $\begin{array}{l}213 \text { Stonegate Circle } \\
\text { Morgantown, WV } \\
26505\end{array}$ & $304-598-0185$ \\
\hline Peter Ngan, DMD & 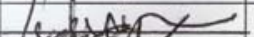 & Dept. of Orthodontics & PO Box 9480 & $293-3222$ \\
\hline Harold Reed, DDS, MS & 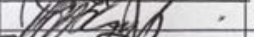 & Dept. of Periodontics & PO Box 9490 & $293-5642$ \\
\hline Tom Razmus, DDS,MS & & Dept. of Radiology & PO Box 9401 & 293-7307 \\
\hline Name or initials & (1) & & Ethics Training 1 & HIPAA Training ${ }^{2}$ \\
\hline Michael Hazey, DDS & & YES if training has been completed & Yes & Yes \\
\hline Peter Ngan, DMD & \multirow{2}{*}{\multicolumn{2}{|c|}{${ }^{1}$ Ethics training: http://www.wvu.edu/ rc/irb/ethi_tra.htm }} & Yes & Yes \\
\hline Harold Reed, DDS, MS & & & Yes & Yes \\
\hline Tom Razmus, DDS,MS & ${ }^{2}$ HIPAA info: htt & $\mathrm{p}: / / \mathrm{www}$.wvu.edu/ rc/irb/index.htm & Yes & Yes \\
\hline
\end{tabular}

3. Estimated period of project or of human subject involvement: Starting date:

$6 / 15 / 04$ Ending date: 6/15/05

4. Reason for conducting research $\square$ Professional Class Assignment $\square$ Other

5. Source of funding (if applicable) West Virginia University SoD Seed Money Grant

6. Number of projected subjects $\quad 125 \quad$ Number of projected records or data files $\quad 125$

7. This research involves (check all that apply - see attached "Exempt Research" page)

$\mathrm{X}$ a Collection or study of existing data, documents, records or specimens, recorded without identifiers

$\square$ b Normal educational practices conducted in established or commonly accepted educationatimo

c Educational tests (cognitive, diagnostic, aptitude, achievement)

d Observation of public behavior

e Surveys, interviews or hand-outs for subjects over 18 (use age ranges, not actual age, for demographic information):
$\square$ Mail
$\square$ Telephone
Person-to-person

f Any possibility of identifying a subject (discuss in cover letter)

APPROVED JUN 302004 065104

$g$ - The possibility that the subject's responses or conduct (if they became public) may place the subject aft OF RESEARCH or civil liability or be damaging to the subject's financial standing or employability

$\square$ h Sensitive aspects of personal behavior (for example: illegal conduct, drug use, sexual behavior or use of alcohol)

$\square$ i Investigator's participation in activities being observed

$\square$ j Only surveys or interviews of elected or appointed public officials or candidates for public office

$\square \mathrm{k}$ Audiotaping

1 Children under age 18 (see Chapter II of the Guidelines) Note: Interviews and surveys with children are never exempt.

$\square \mathrm{m}$ Food tasting and evaluation

n Research and demonstration projects

o Access to protected health information (PHI) (See HIPAA requirements: http://www.wvu.edu/ rc/irb/index.htm)

8. Goal of research 
- To evaluate the utility of ImageIQ in maxillofacial radiography by comparing the visual acuity of practitioners to interpret clinical, diagnostic rendered images using ImageIQ relative to interpretation without ImageIQ.

- To determine the correlation of ImageIQ surface topography from clinical findings.

- To determing the clinically relevant range or extent of Image IQ navigational changes that correlate with beam angulations.

- To determine whether ImageIQ can provide clinical information relative to diagnosis of periodontal defects.

Revised Dec 2003

9. Explanation of procedures involved in research

Simulated periodontal defects with varying diameters and depths will be placed in 125 dried cadaver mandibles, which were ordered from a company, and therefore are anonymous and have no identifiers.

Each mandible will be radiographed at 3 different exposure times and 3 different horizontal and vertical angulations.

These radiographs will be rendered using LumenIQ's ImageIQ software providing 3D topographical images.

Three oral pathology/radiology evaluators will answer questions comparing the original radiographs to the ImageIQ rendered

images.

The data will provide information on the optimal exposure settings and angulations that will provide the most useful ImageIQ image of the simulated periodontal defects.

The data will also provide information on the overall benefits that dental practicioners may find with using the Image IQ 3D

renderings in diagnosing periodontal defects.

10. Explanation of known risks to human subjects

11. Explanation of how records will be kept

The 125 dried cadaver mandibles, will be kept in a locked research lab.

as well as any records

A cover letter addressed to respondents must accompany any survey or questionnaire. The cover letter must be on the investigator's $W V U$ departmental letterhead and must include the following:

1 a statement that the project is research being conducted in partial fulfillment of the requirements for a course, master's thesis, dissertation, etc.

2 purpose of study

3 a statement that subjects' responses will be kept anonymous or confidential (explain extent of confidentiality if subjects' names are requested)

4 if audiotaping, a statement that subject is being audiotaped (explain how tapes will be stored or disposed of during and after the study)

5 a statement that subjects do not have to answer every question

6 a statement that subject's class standing, grades, or job status (or status on an athletic team, if applicable) will not be affected by refusal to participate or by withdrawal from the study

7 a statement that participation is voluntary

Attachments:

questionnaire/survey to be used

telephone text (including introductory remarks as in a cover letter-see above)

cover letter

permission from external institution, on their letterhead (if applicable) 


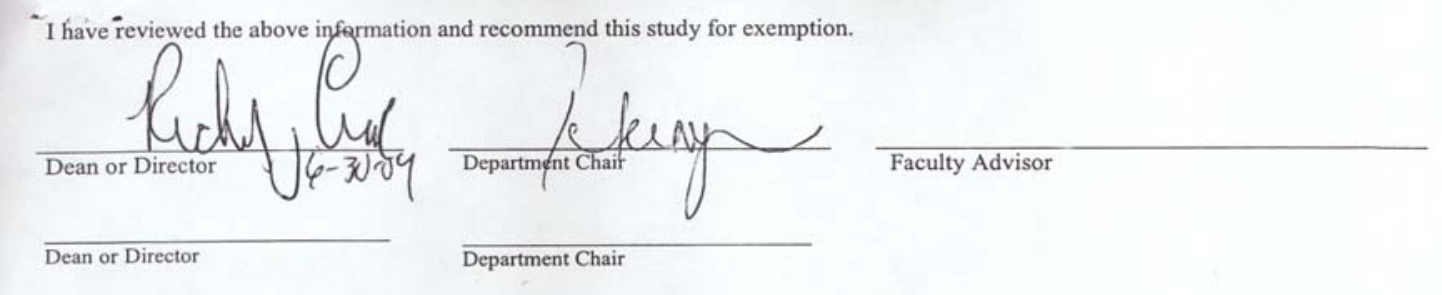


APPENDIX B

ORIENTATION PHASE POWERPOINT 


\section{WVU-LumenlQ Phase 1 Orientation/Evaluation}

Dr. Michael Hazey - WVU Department of Orthodontics

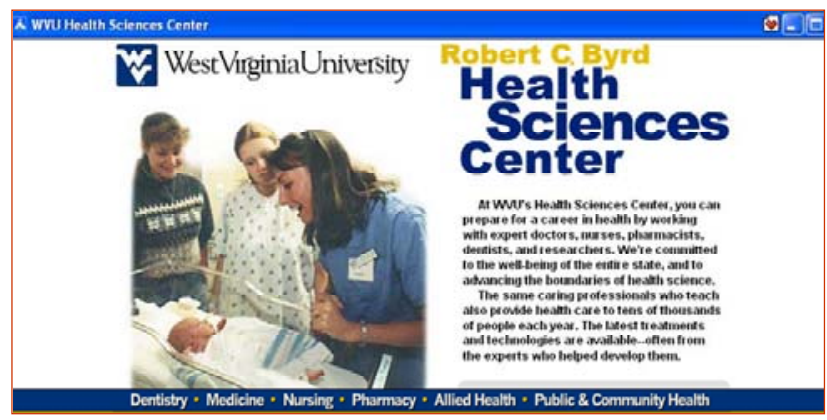

Lumen|

\section{Background Information}

- The Purpose of this exercise is to evaluate a computer imaging program, IMAGEIQ, which produces 3-D topographical renderings of standard 2-D radiographs.

- ImagelQ has the ability to render radiographs using color enhancements, contourline placement, and rotation of the image, in addition to topographical simulation.

- You will be shown a combination of these types of renderings and will be asked to evaluate and compare them to standard digitized radiographs by answering a series of questions on your evaluation sheet.

- The next slide will provide examples of what you will be shown.

Lumeng

Confidential 


\section{Background Information}

- Each case number will be followed by a letter " $a$, b, or c".

- Letter "a" represents the standard unmodified digitized radiograph. Ex. to the right.

- Letter "b" represents the ImagelQ topographical rendering of the standard radiograph. In some cases, you may be shown more than one rendering. Ex. To the right.

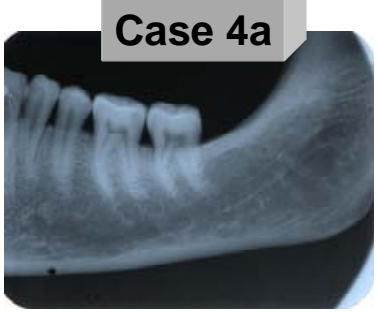

Case 6b

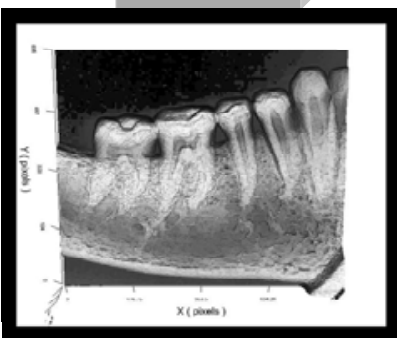

\section{Background Information}

- Each case number will be followed by a letter " $a, b$, or c".

- Letter "a" represents the standard unmodified digitized radiograph. Ex. to the right.

- Letter "b" represents the ImagelQ topographical rendering of the standard radiograph. In some cases, you may be shown more than one rendering. Ex. To the right.

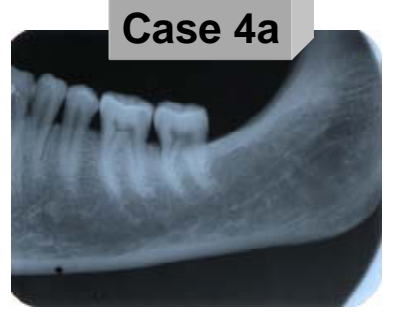

Case 6b

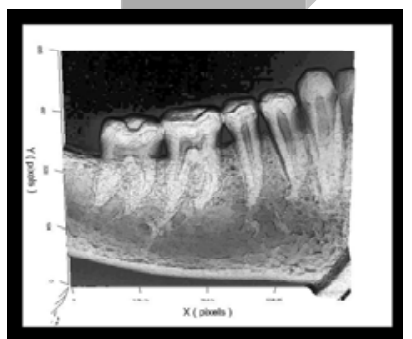




\section{Directions}

1. If you have not already done so, please press F5 to view this evaluation in a slide show format.

2. To advance the slides, press the right arrow. To go back through the slides, press the left arrow.

3. There are 12 cases ( 3 parts per case labeled " $a, b, c$ ")

4. Please circle your answers to the blue questions on the evaluation sheet located to the right of the case part $(a, b$, or $c)$ you are evaluating.

5. Your cooperation is greatly appreciated!!

\section{Case 12}

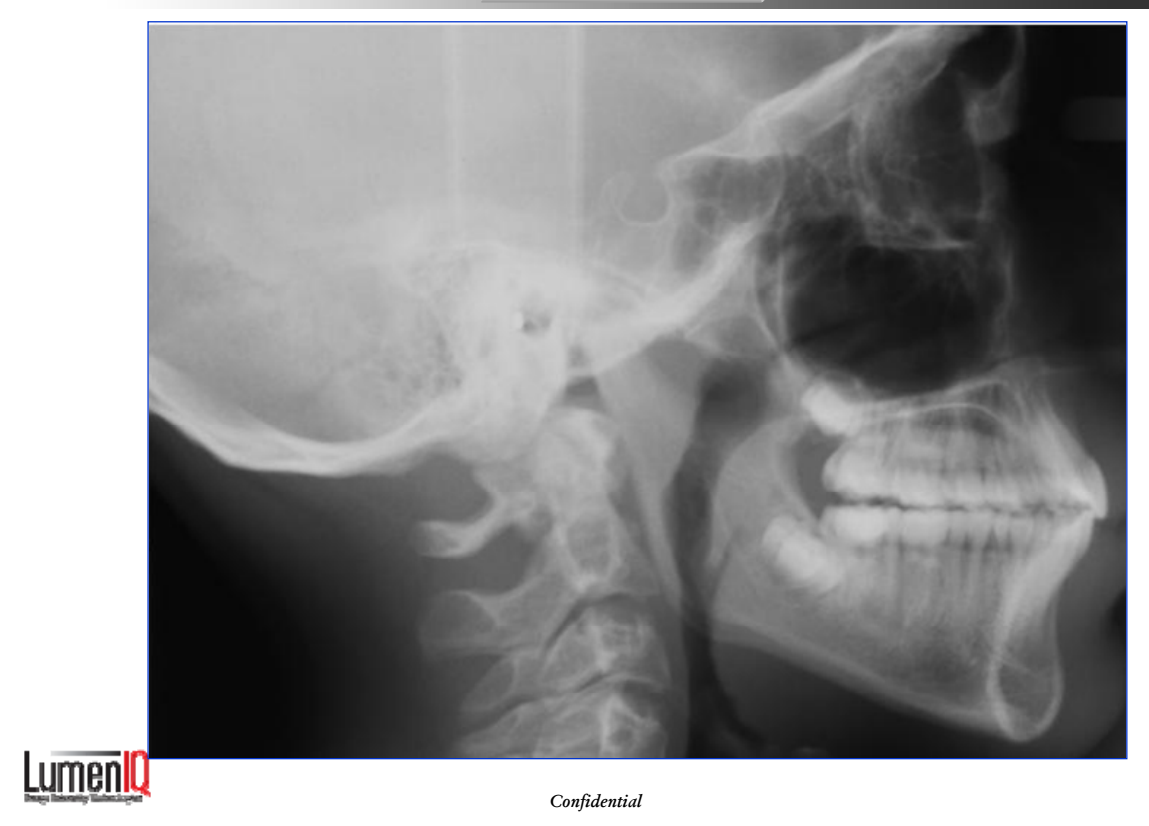



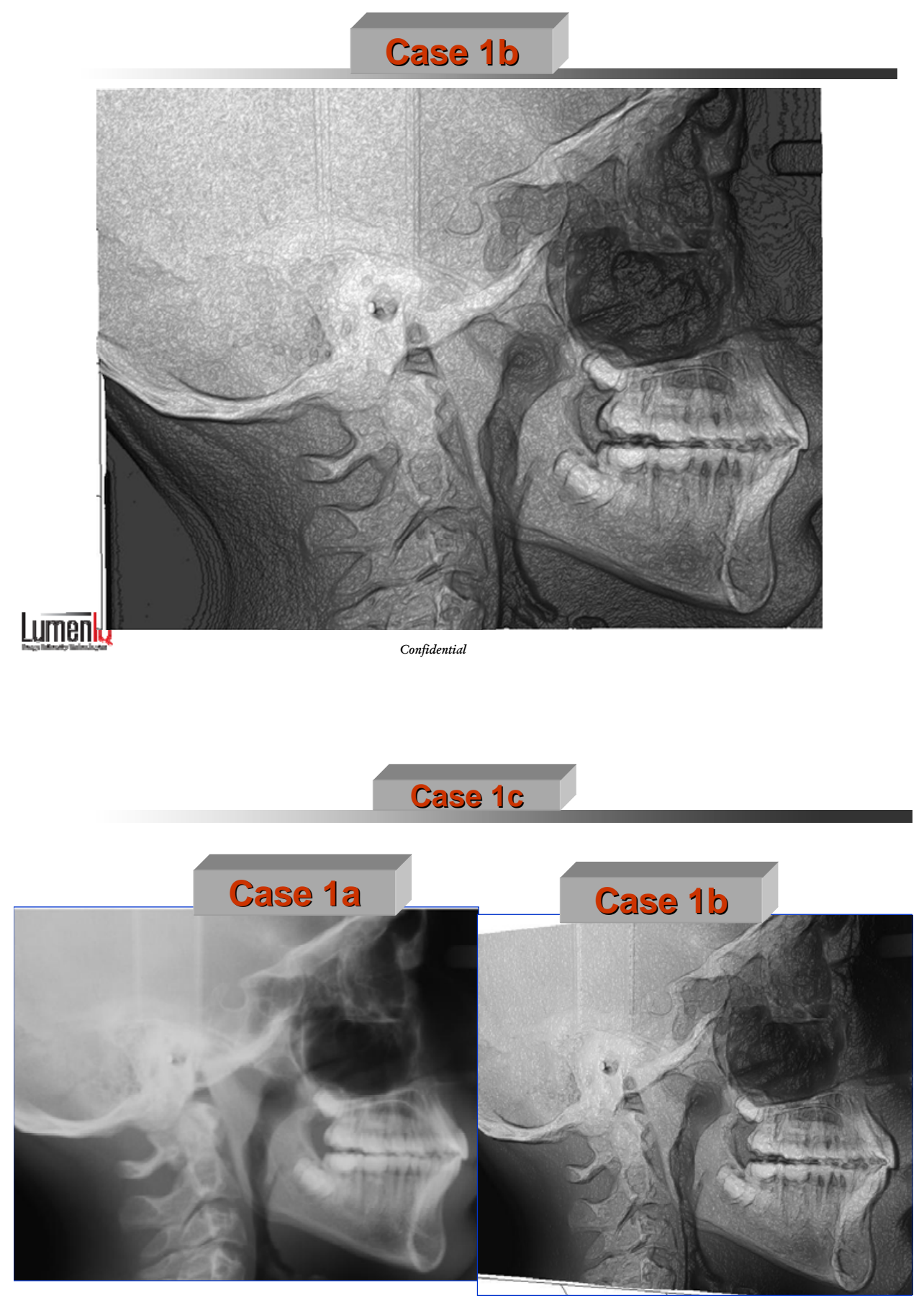

LLumen|l

Confidential 


\section{Case 2a}

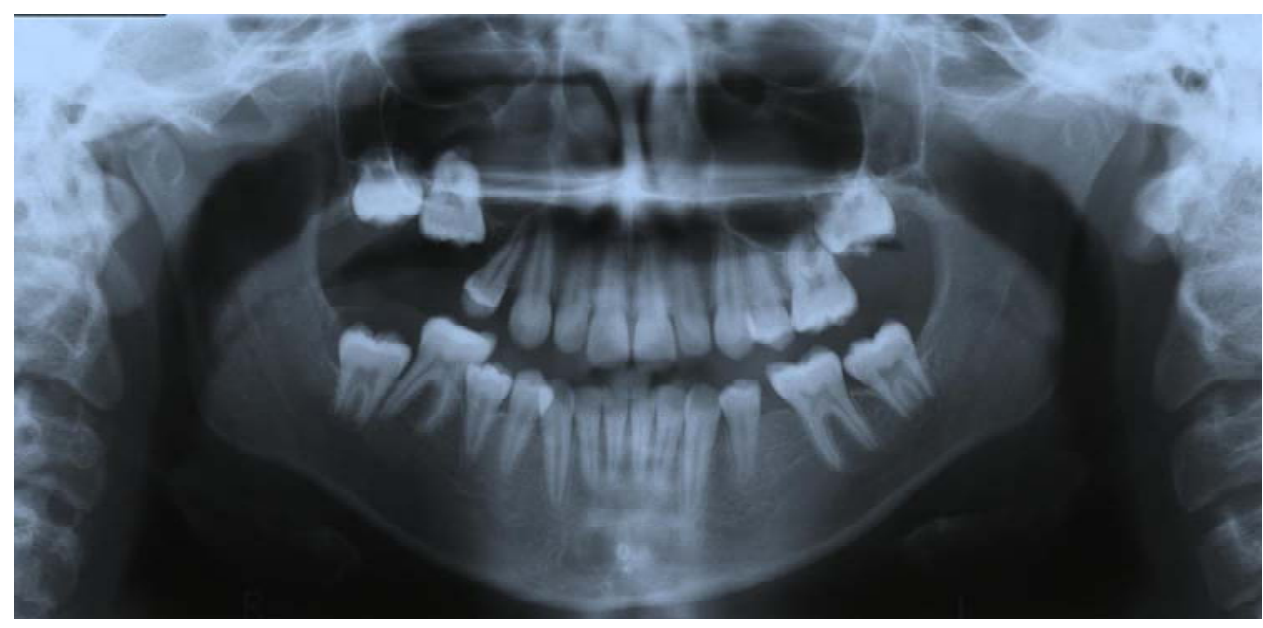

Lumenl0

Confidential

\section{Case 2b}

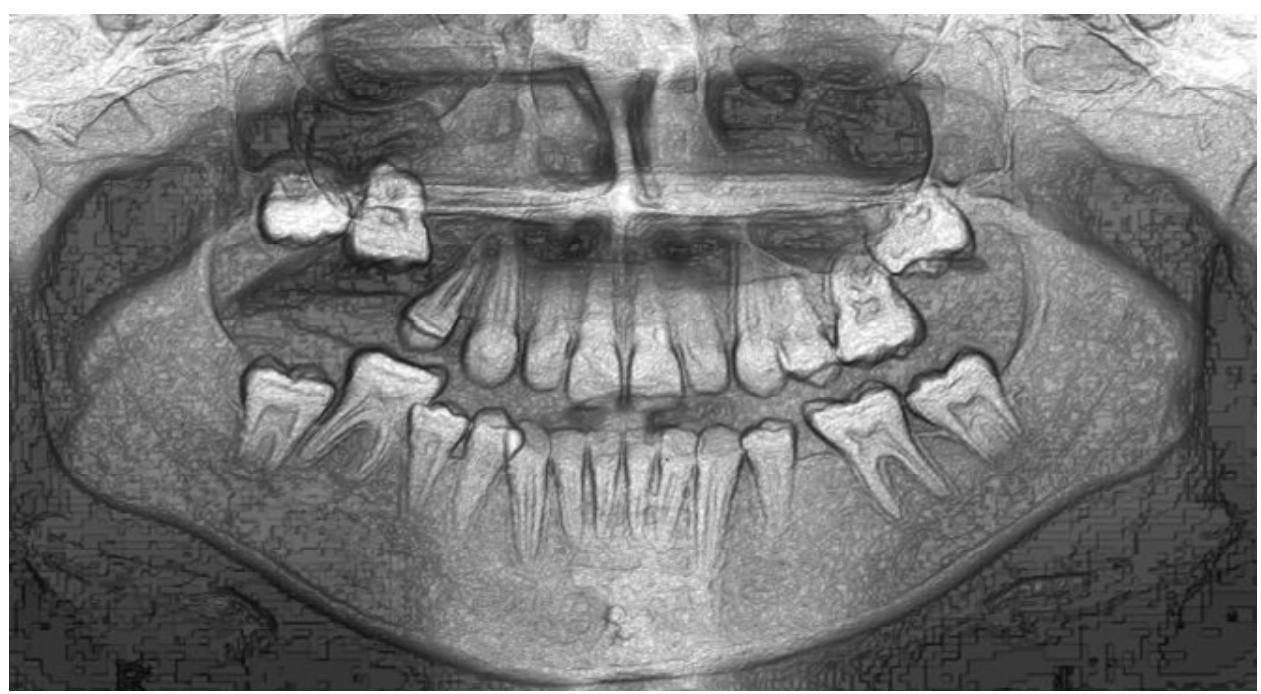

Lumen|l

Confidential 

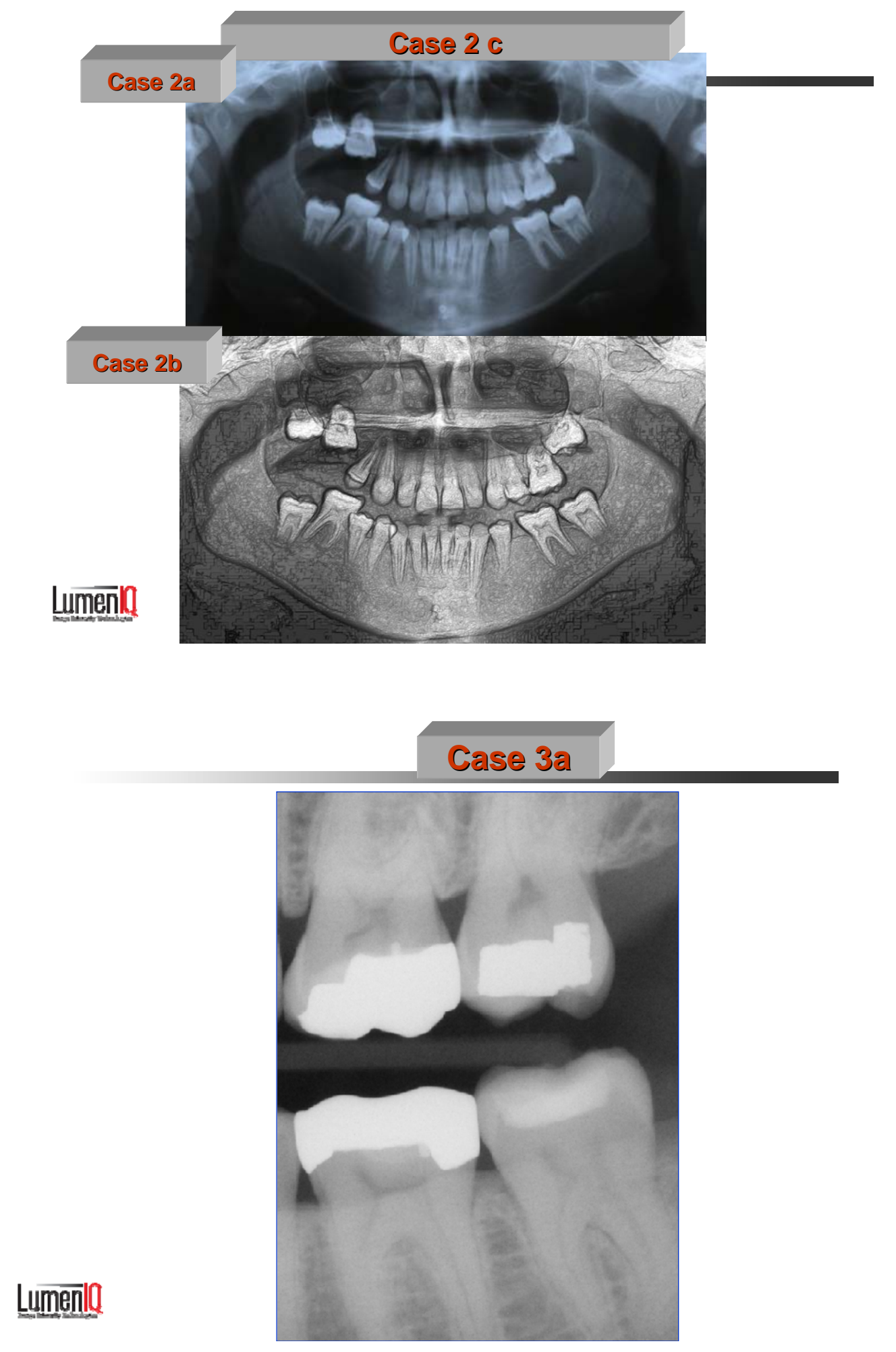


\section{Case 3b}

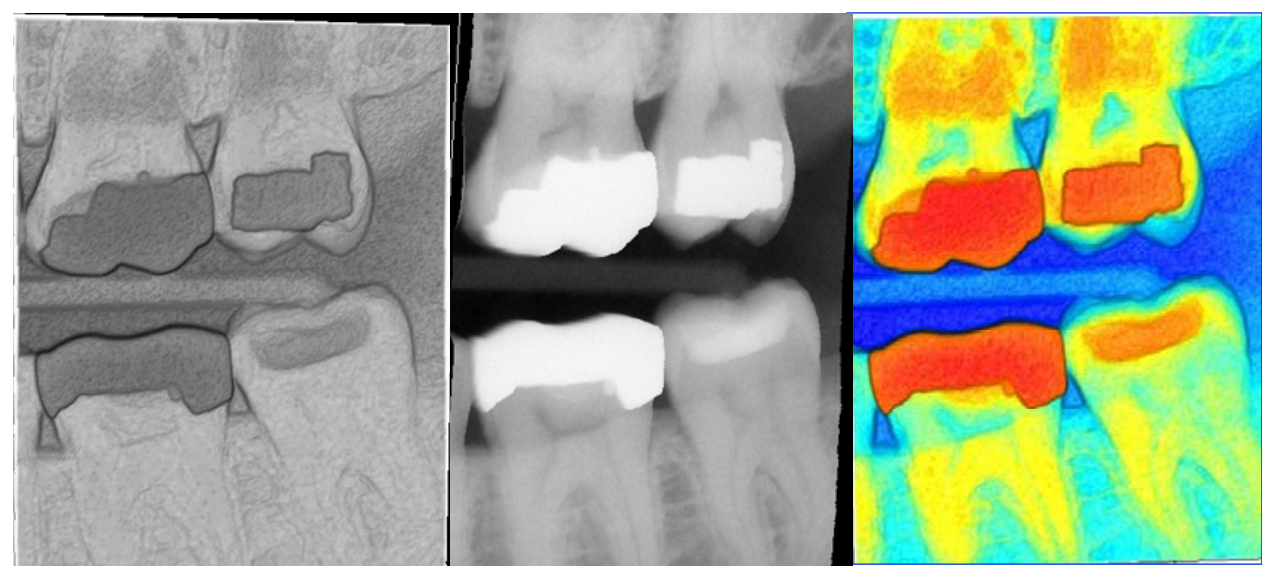

Lumen|l

Confidential

\section{Case 36}

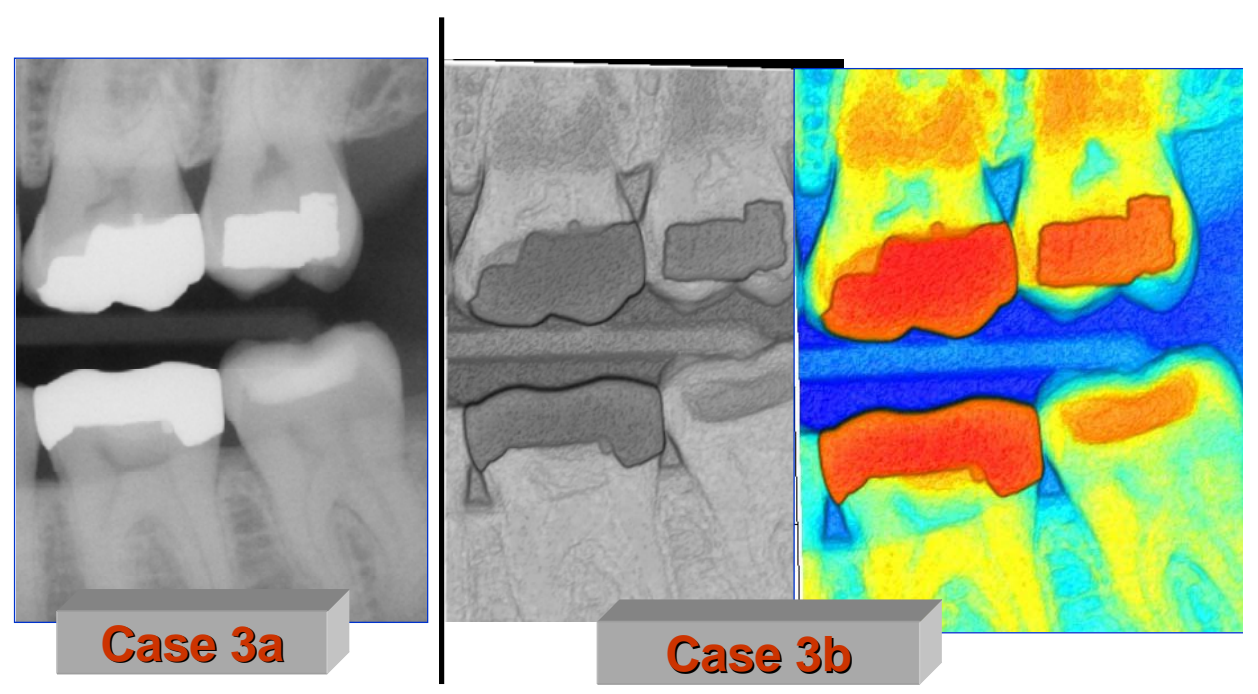

LumenlQ

Confidential 

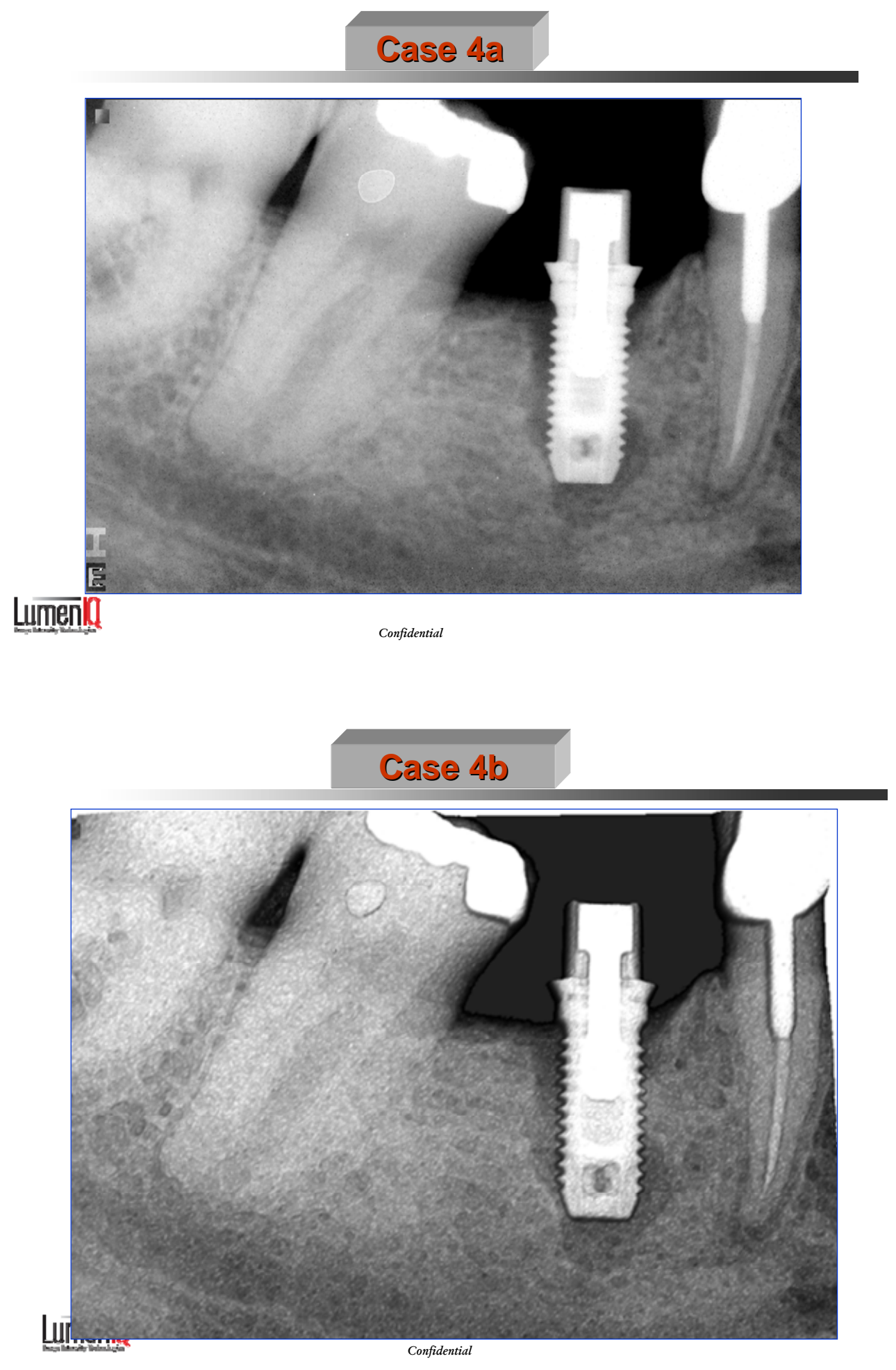


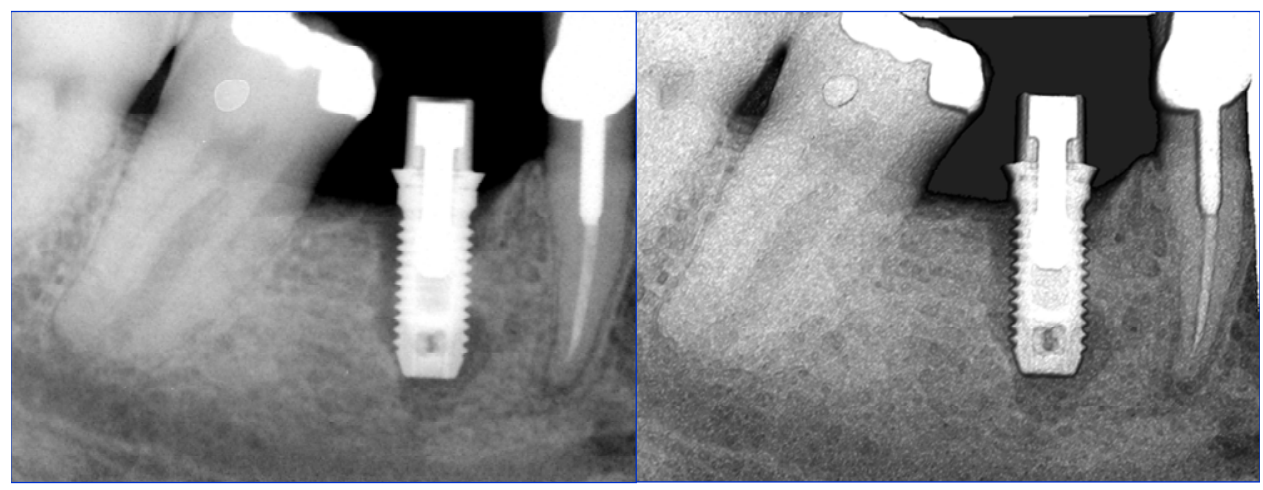

Lumen|

Confidential

\section{Case 5a}

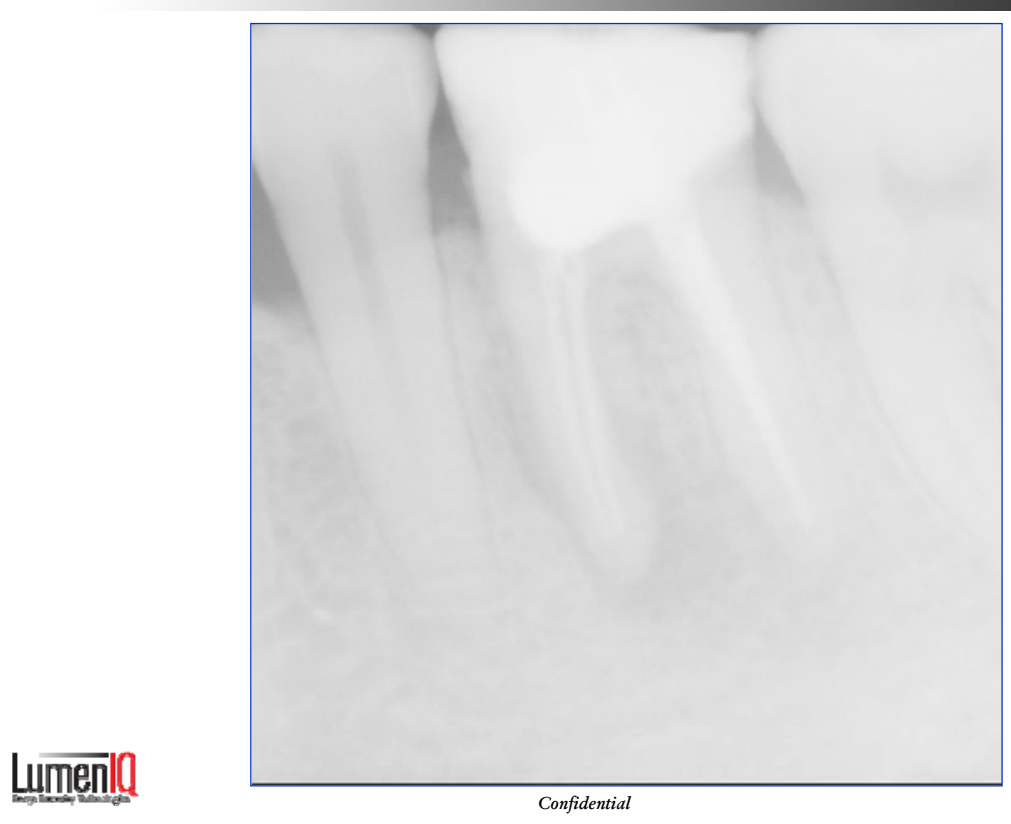



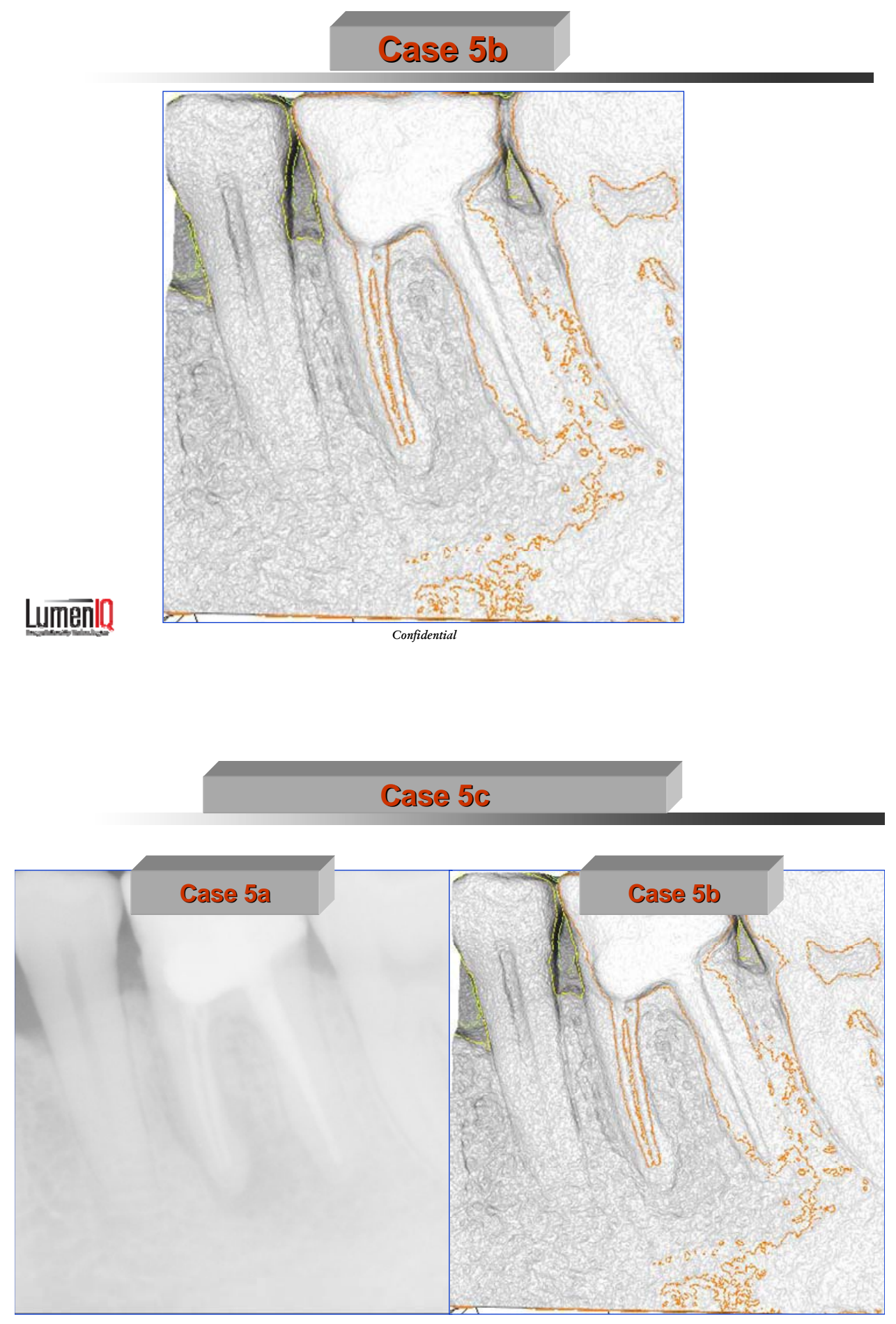

Lumenll

Confidential 

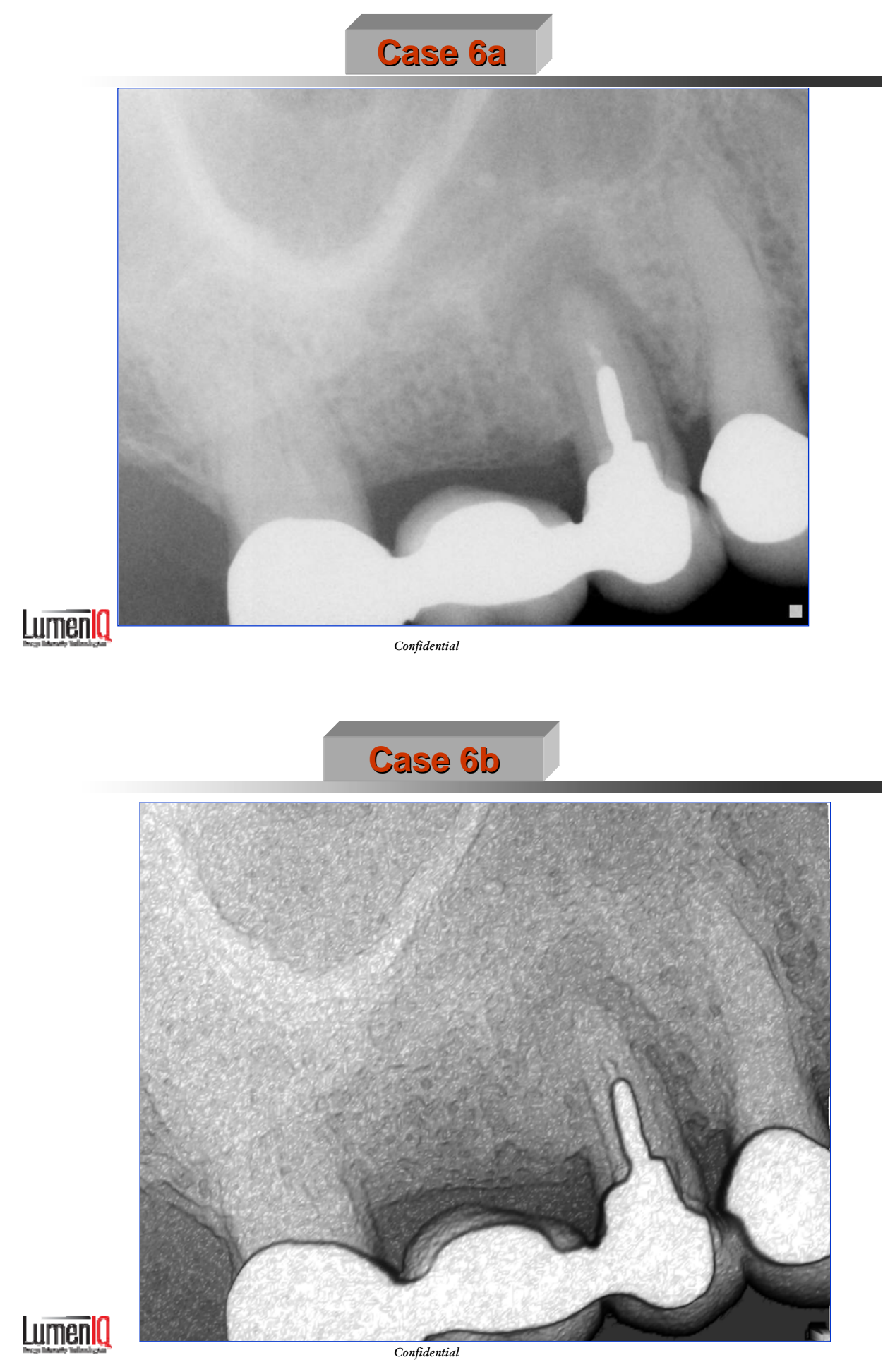


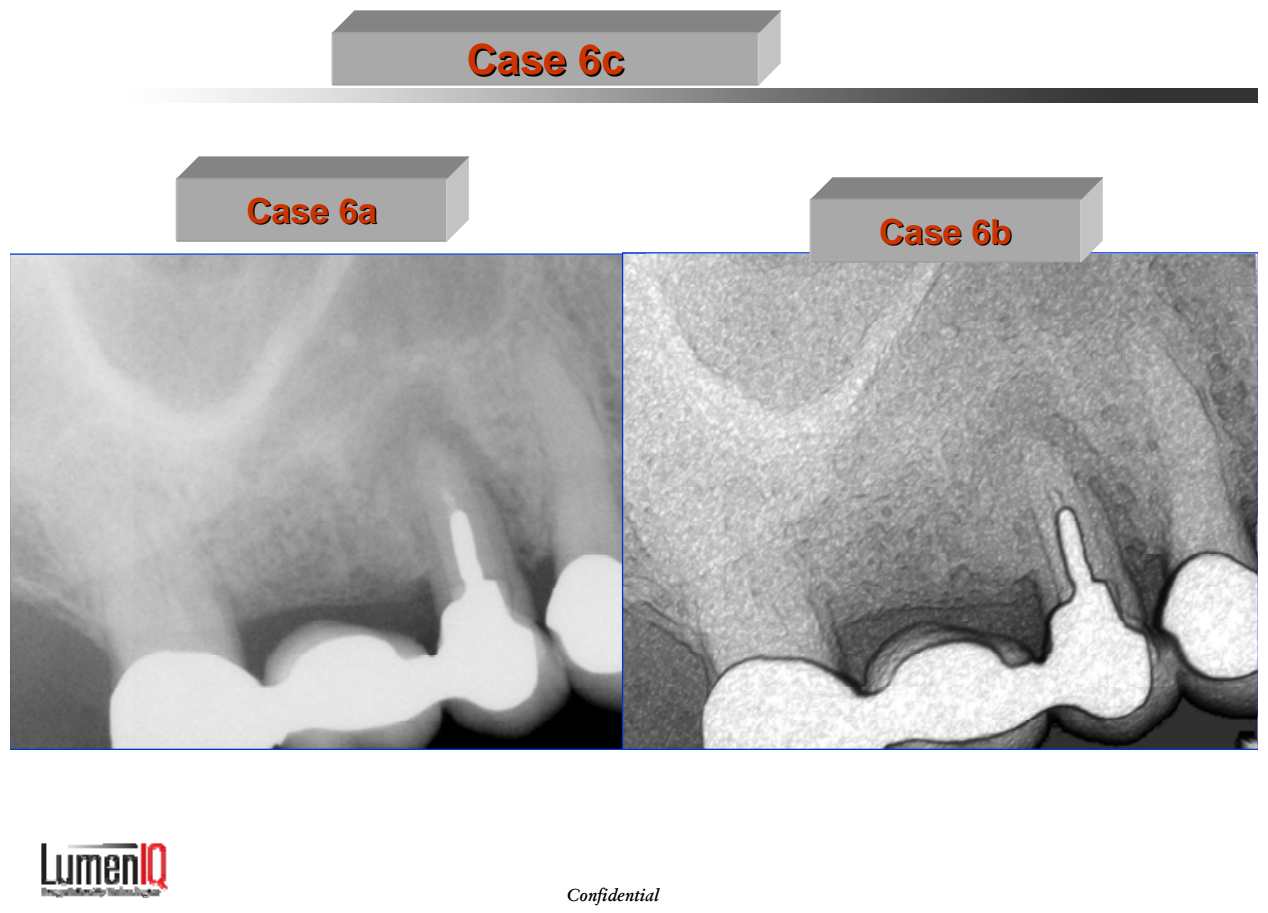

Case 72

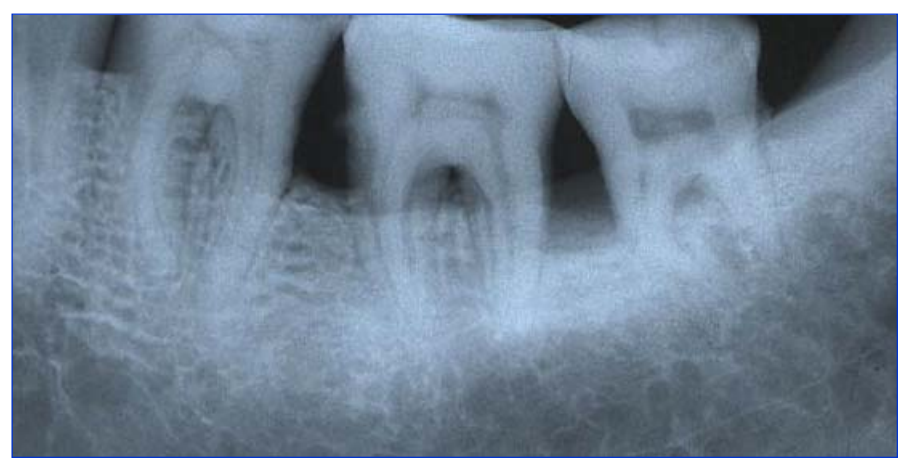

Lumenll Confidential 

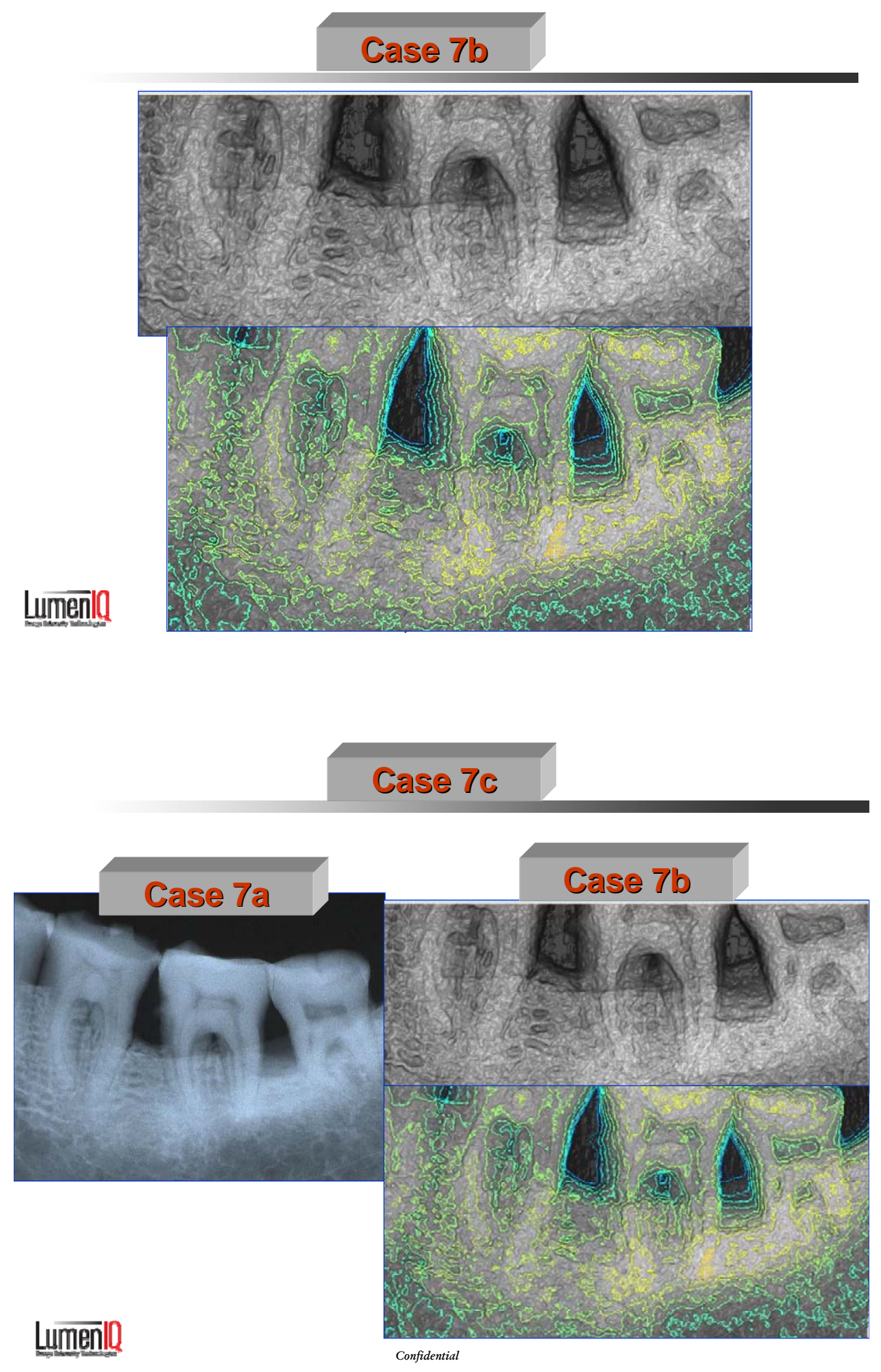


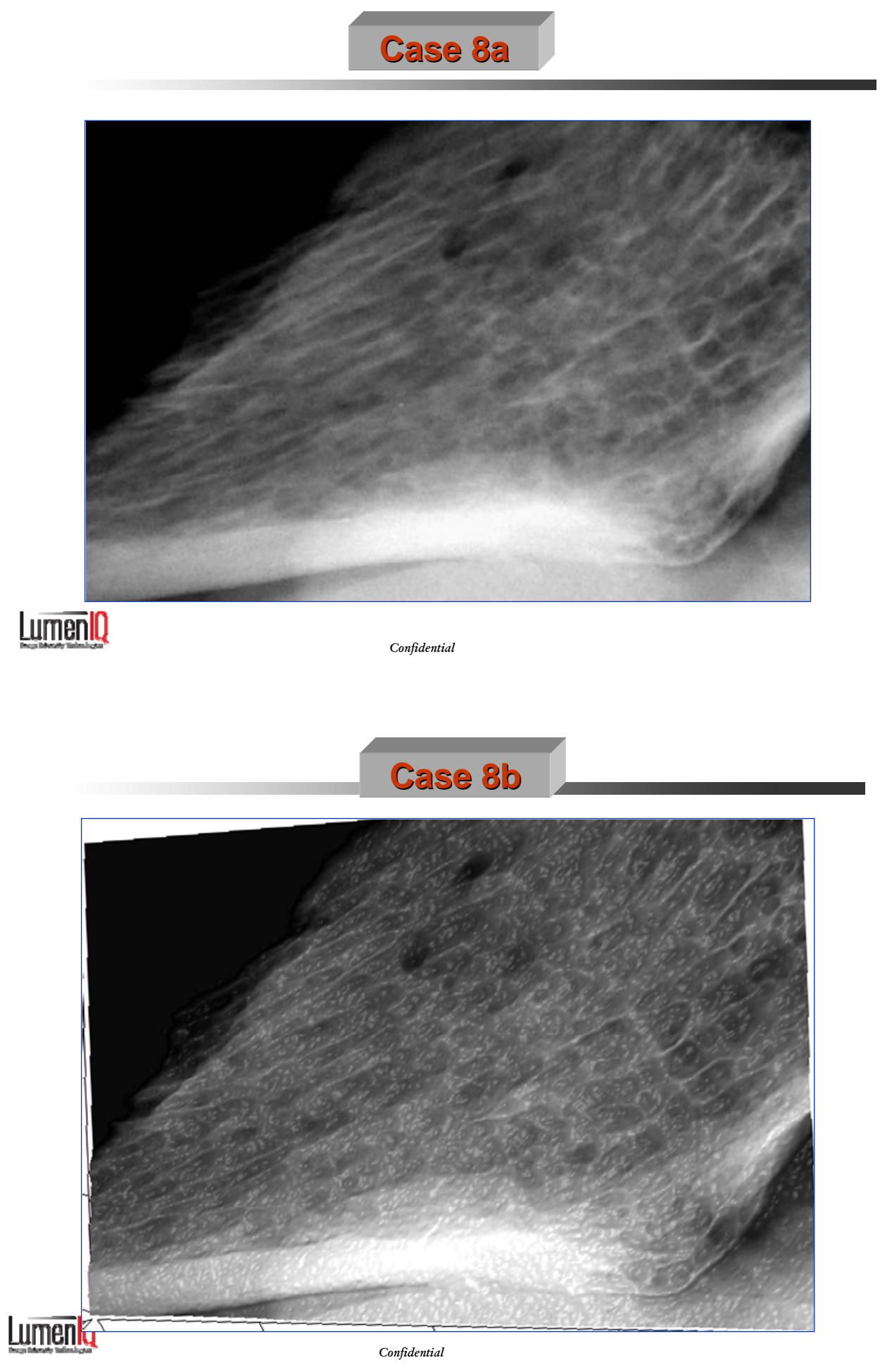




\section{Case $8 \mathrm{C}$}

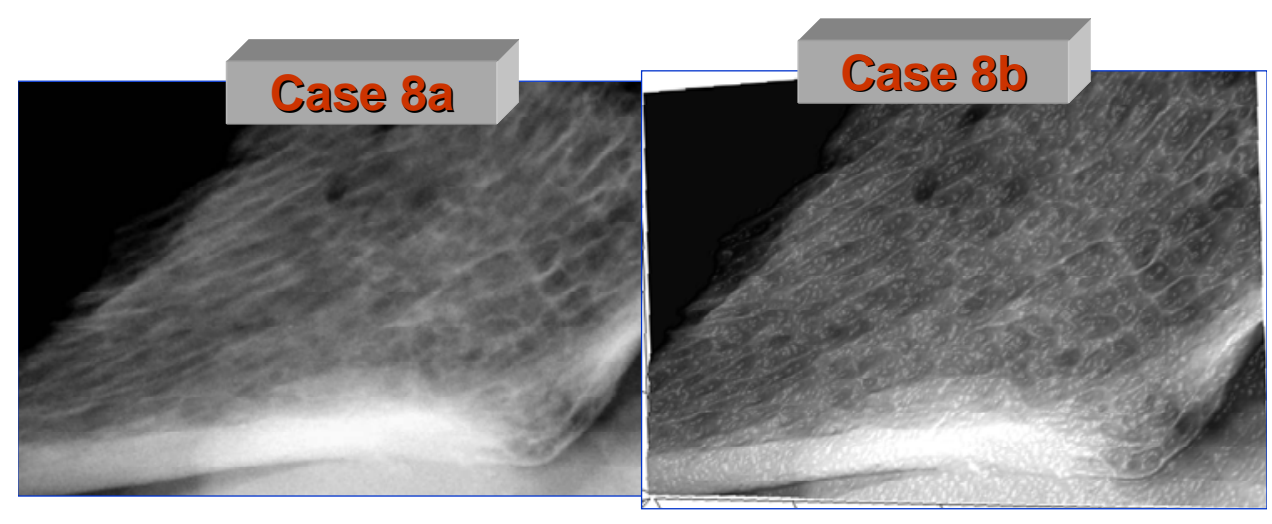

Lumen!l

Confidential

Case 9a

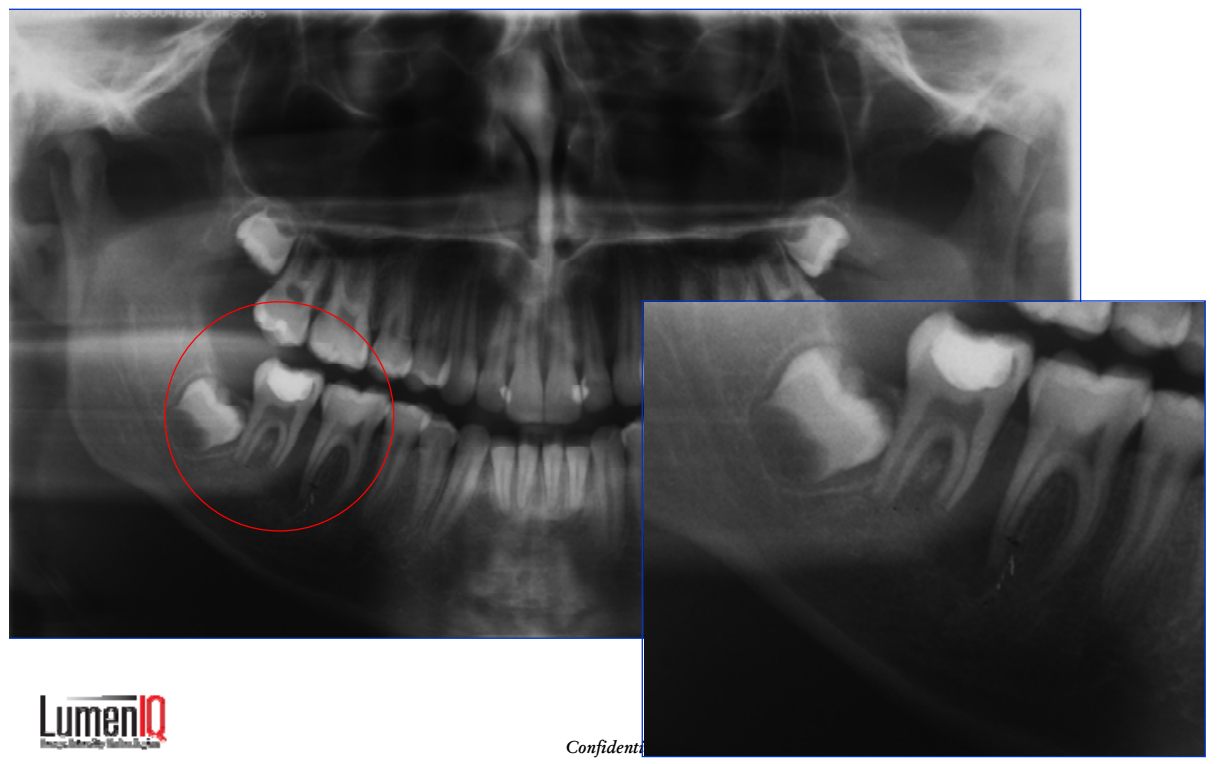




\section{Case 9b}
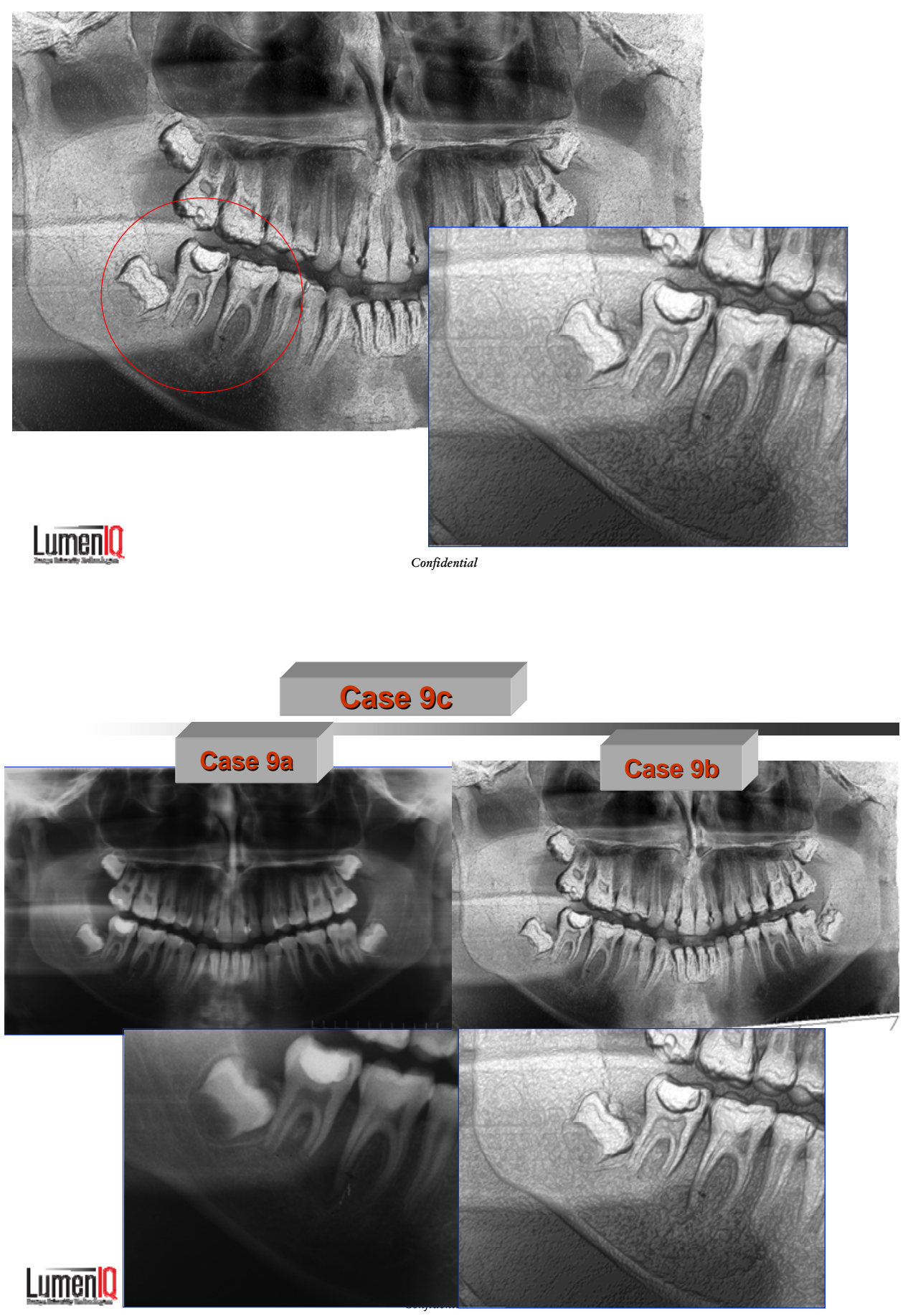

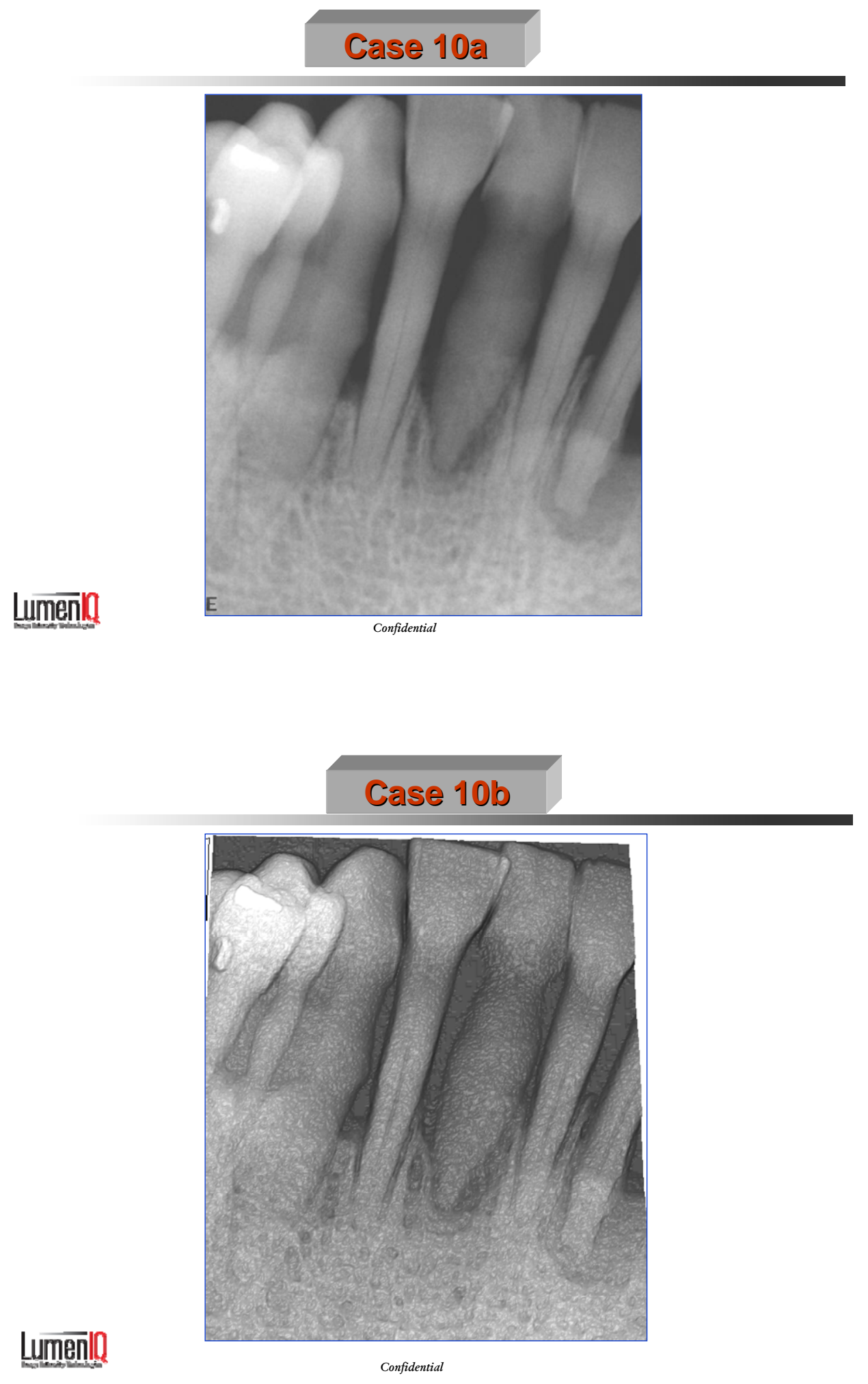


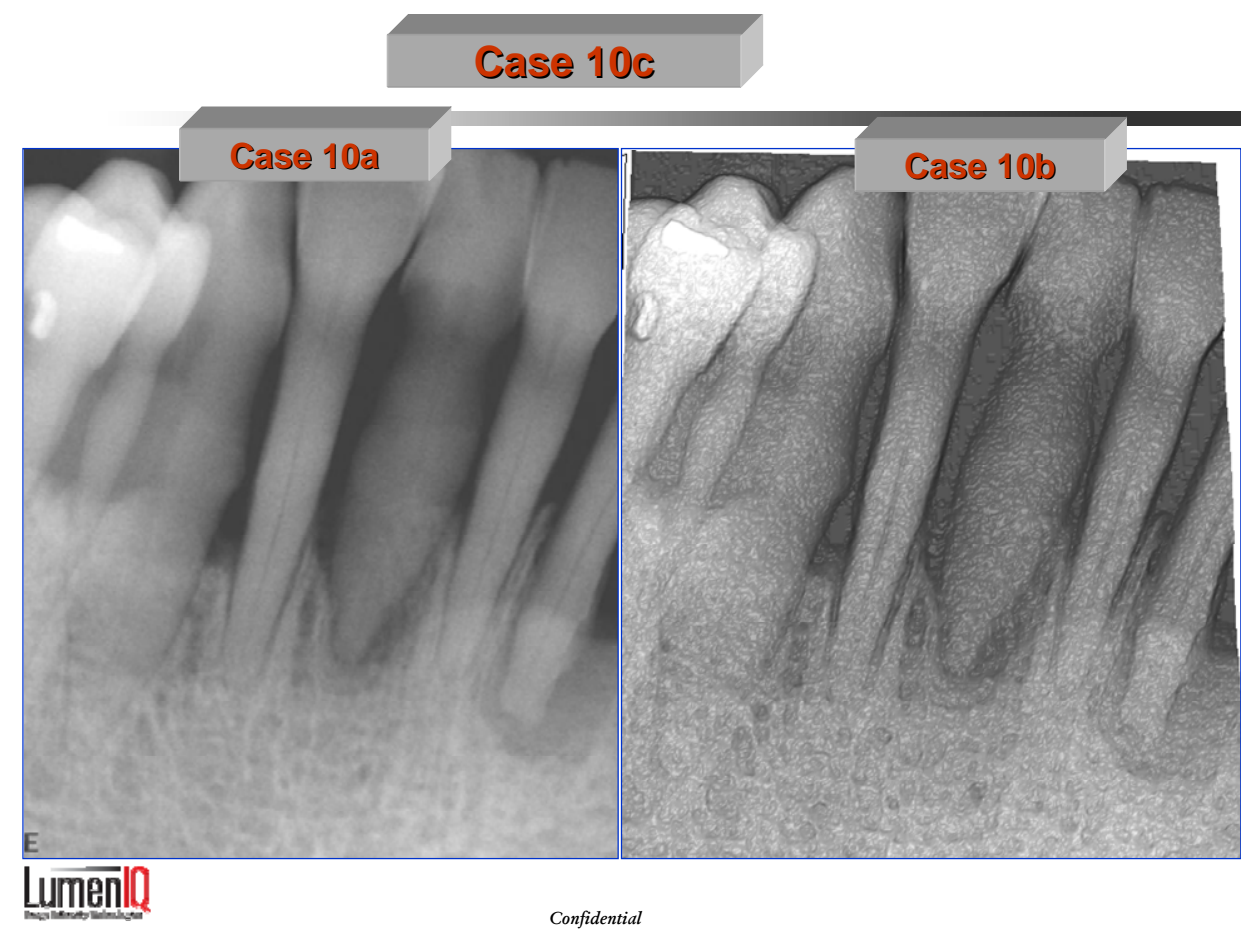

\section{Case 112}

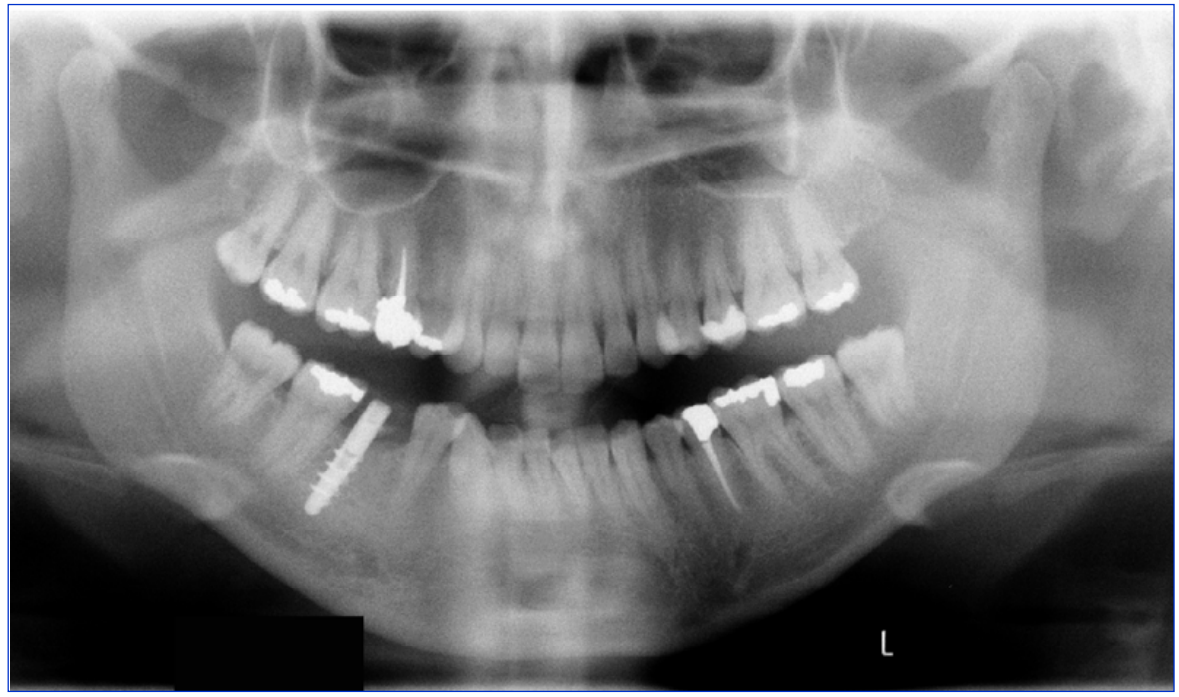

Lumen!

Confidential 

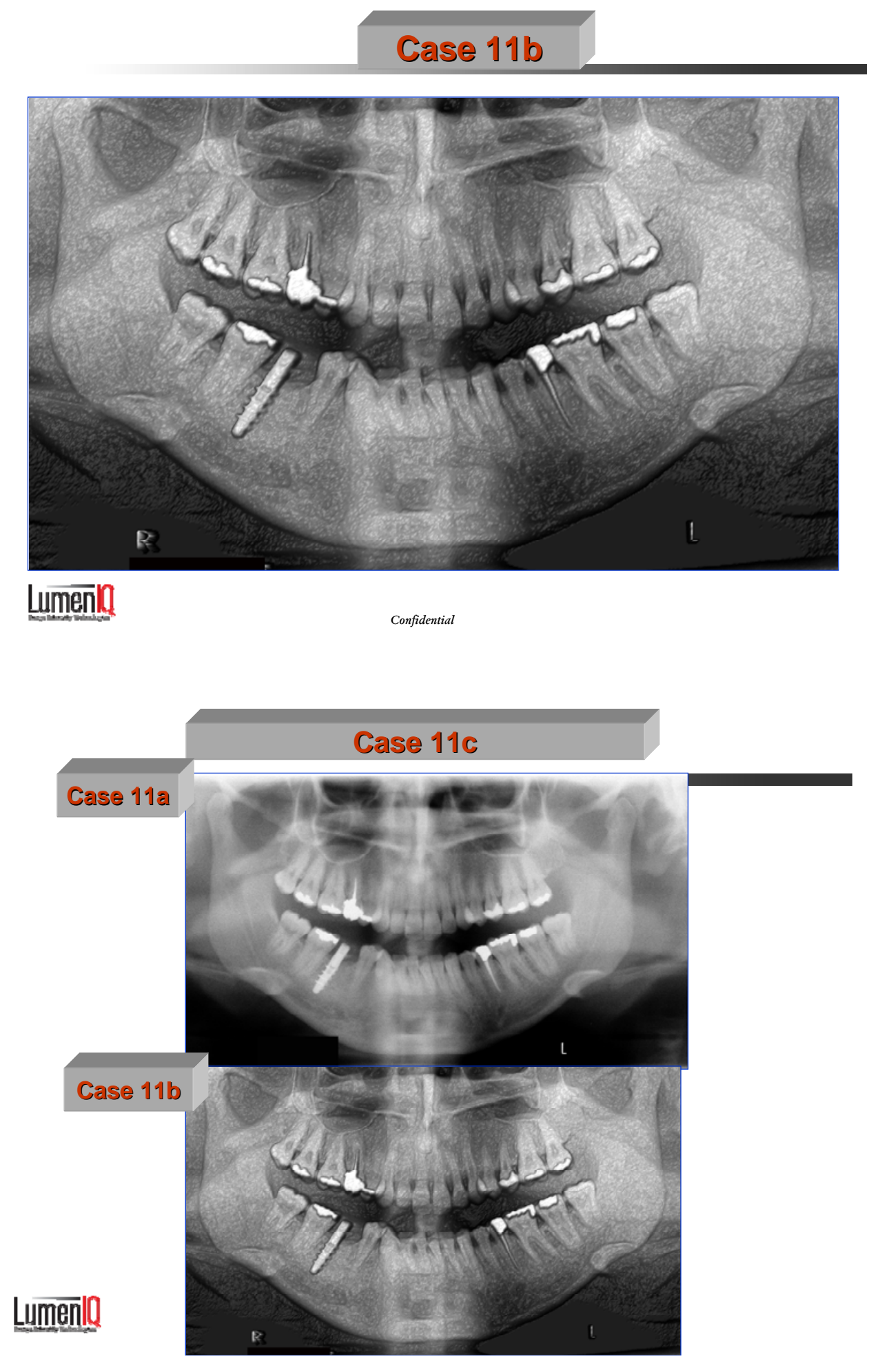


\section{Case $12 a$}

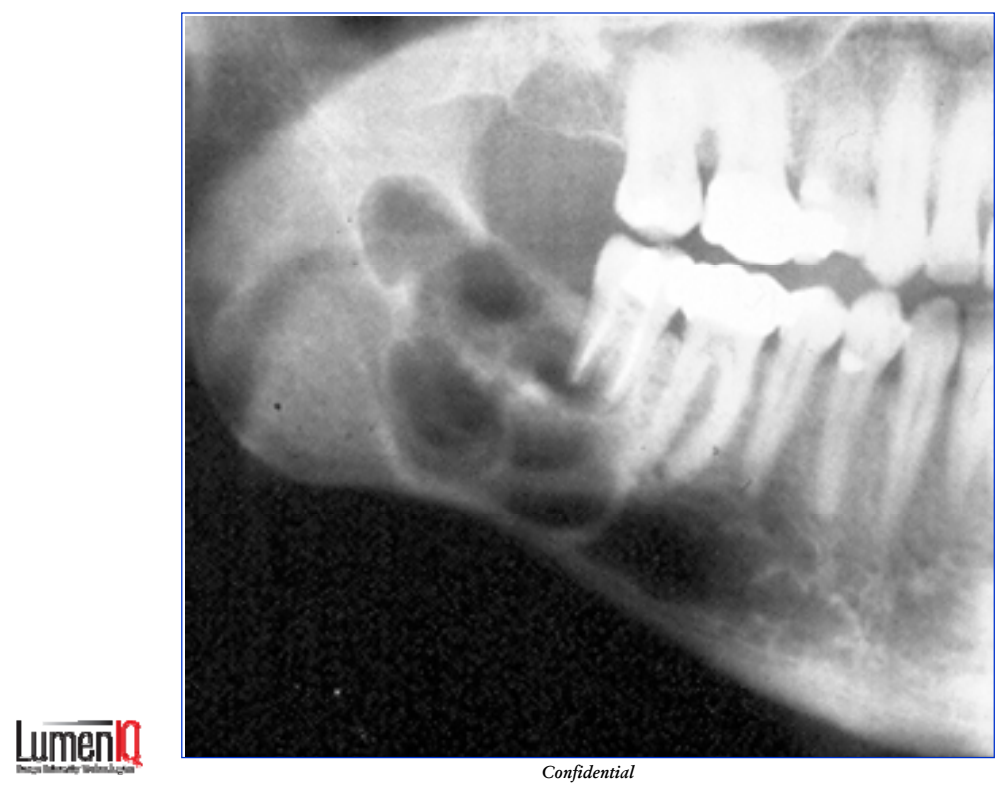

\section{Case 12b}

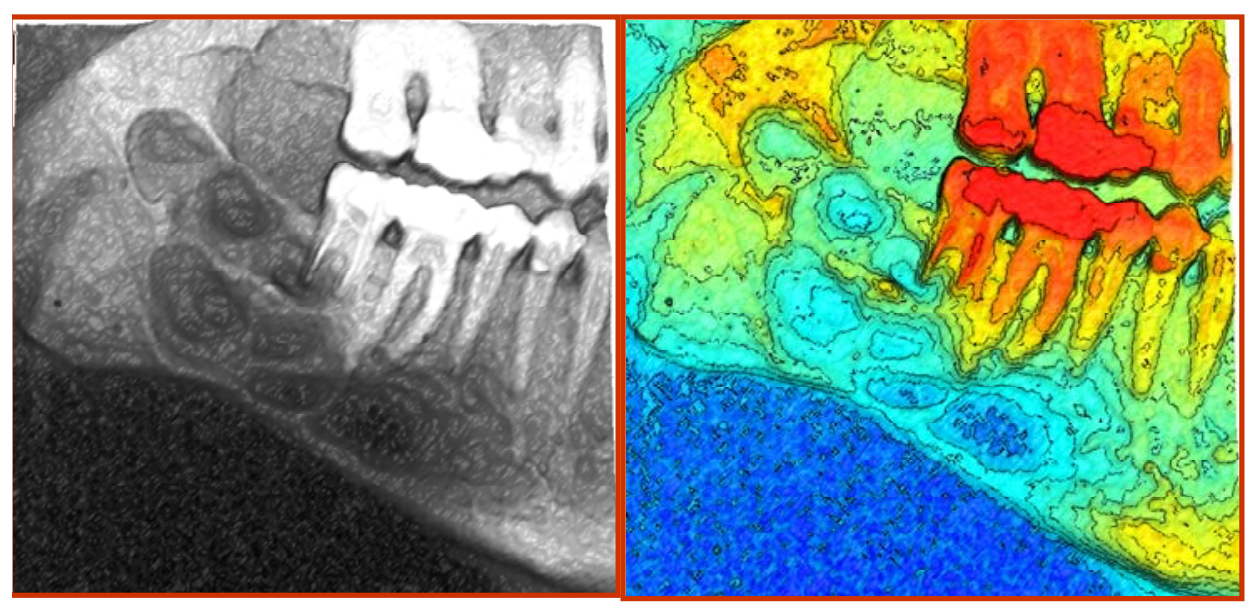

Lumeñ

Confidential 

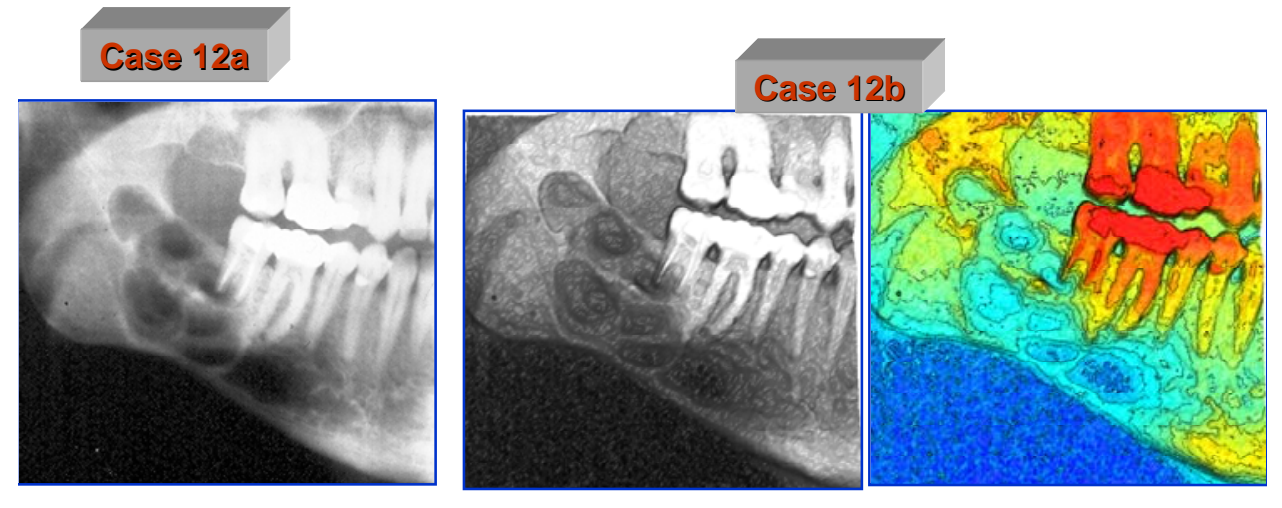

Lumen!l

Confidential 
- You have finished this evaluation.

- You may close this program and return your answer sheet to Dr. Michael Hazey in the Orthodontics Department.

- Thank you for your cooperation. 


\section{APPENDIX C \\ ORIENTATION PHASE QUESTIONAIRE}




\section{Evaluation of LumenIQ Radiographic Imaging Software}

\section{Dear Doctors,}

Thank you for taking the time to complete the enclosed case evaluation. This evaluation is anonymous and intended to assess the usefulness of new radiographic imaging software.

Please circle the appropriate representation of your years of clinical experiences, clinical status, and your specialty.

\begin{tabular}{|c|c|c|c|c|}
\hline \multirow{2}{*}{$\begin{array}{l}\text { Evaluation ID \# } \\
\text { Years of clinical experience }\end{array}$} & \multirow[b]{2}{*}{$1-5$} & \multirow[b]{2}{*}{$6-10$} & \multirow[b]{2}{*}{$11-15$} & \multirow[b]{2}{*}{$>\mathbf{2 0}$} \\
\hline & & & & \\
\hline Clinical status & Student & Resident & $\begin{array}{c}\text { Clinical } \\
\text { Instructor }\end{array}$ & $\begin{array}{c}\text { Private } \\
\text { Practitioner }\end{array}$ \\
\hline \multirow[t]{2}{*}{ Specialty } & Periodontics & Radiology & Orthodontics & OMFS \\
\hline & Endodonties & Prosthodontics & OMFP & General Dentistry \\
\hline
\end{tabular}




\section{DIRECTIONS}

Please insert the provided CD-ROM into your computer's CD-ROM Drive.

If a box appears showing the contents of the CD-ROM, Left Click on "WVU LumenIQ Evaluation ppt."

If no box appears follow these instructions:

On your Desktop, Left Click on 'My Computer'

Left Click on the CD-ROM drive

Left Click on "WVU LumenIQ Evaluation ppt."

Microsoft Powerpoint will open and the first slide labeled "WVU-LumenIQ Phase 1 Orientation/Evaluation" will appear.

Press the F5 key to view the powerpoint in a Slide Show format.

Press the forward arrow key to advance the slides

Press the back arrow key to move back to a previous slide if desired.

The evaluation consists of 12 cases with 3 parts each labeled "a, b, c".

Please circle your answers to the questions in blue for the case part you are evaluating.

When asked to give a confidence level of your interpretation, please write a percentage from $0-100 \%$ in the box provided.

Thank you 


\section{Case 1}

\begin{tabular}{|c|c|c|c|c|c|c|c|c|}
\hline Case \# & Image Quality: & \multicolumn{2}{|c|}{$\begin{array}{l}\text { Anatomical } \\
\text { structure }\end{array}$} & \multicolumn{2}{|c|}{$\begin{array}{l}\text { If pathology exists, } \\
\text { where is it located? }\end{array}$} & $\begin{array}{l}\text { Conspicuity of } \\
\text { the image: } \\
\text { (how obvious is } \\
\text { the normalcy or } \\
\text { pathology) }\end{array}$ & $\begin{array}{c}\text { Confidence level } \\
\text { of exam } \\
\text { (how sure are } \\
\text { you) }\end{array}$ & $\begin{array}{l}\text { Fatigue level viewing image } \\
\text { (low or high strain in } \\
\text { discerning the image) }\end{array}$ \\
\hline 1a & $\begin{array}{ll}\text { - } & \text { Good } \\
\text { - } & \text { Poor }\end{array}$ & \multicolumn{2}{|c|}{$\begin{array}{ll}\cdot & \text { Normal } \\
- & \text { Abnormal } \\
- & \text { Diagnostic } \\
\text { Challenge }\end{array}$} & \multicolumn{2}{|l|}{$\begin{array}{ll}\text { - } & \text { Maxilla } \\
\text { - } & \text { Mandible } \\
\text { - } & \text { Both } \\
\text { - NA } & \text { NA }\end{array}$} & $\begin{array}{ll}\text { - } & \text { Excellent } \\
\text { - } & \text { Good } \\
\text { - } & \text { Poor } \\
\text { - NA }\end{array}$ & $0-100 \%$ & Low $1-2-3-4-5$ high \\
\hline$\underline{1 b}$ & $\begin{array}{l}\text { - } \quad \text { Good } \\
\text { - } \quad \text { Poor }\end{array}$ & \multicolumn{2}{|c|}{$\begin{array}{ll}\cdot & \text { Normal } \\
- & \text { Abnormal } \\
\text { - } & \text { Diagnestic } \\
\text { Challenge }\end{array}$} & \multicolumn{2}{|l|}{$\begin{array}{ll}\text { - } & \text { Maxilla } \\
\text { - } & \text { Mandible } \\
\text { - } & \text { Both } \\
\text { - } & \text { NA }\end{array}$} & $\begin{array}{ll}\text { - } & \text { Excellent } \\
\text { - } & \text { Good } \\
\text { - } & \text { Poor } \\
\text { - NA } & \text { Noor }\end{array}$ & $0-100 \%$ & Low $1-2-3-4-5$ high \\
\hline$\underline{1 c}$ & \multicolumn{2}{|c|}{$\begin{array}{l}\text { Is there improved image } \\
\text { clarity between the } \\
\text { images? } \\
\text { Yes no } \\
\text { if so which is better? } \\
\text { 1a or 1b? } \\
\text { How much improvement? } \\
\text { small improvement } \\
\text { large improvement }\end{array}$} & \multicolumn{2}{|c|}{$\begin{array}{l}\text { * Are you able to } \\
\text { discern more details } \\
\text { from the one image? } \\
\text { (ie skeletal landmarks } \\
\text { porion, sella, nasal spine } \\
\text { etc) } \\
\text { Yes No } \\
\text { * Which image has } \\
\text { more detail? } \\
\text { la 1b }\end{array}$} & & \multicolumn{3}{|c|}{ Personal observations or comments: } \\
\hline
\end{tabular}




\section{Case 2}

\begin{tabular}{|c|c|c|c|c|c|c|c|}
\hline Case \# & Image Quality: & \multicolumn{2}{|c|}{ Anatomical structure } & $\begin{array}{l}\text { If pathology exists, } \\
\text { where is it located? }\end{array}$ & $\begin{array}{l}\text { Conspicuity of } \\
\text { the image: } \\
\text { (how obvious is } \\
\text { the normalcy or } \\
\text { pathology }\end{array}$ & $\begin{array}{l}\text { Confidence } \\
\text { level of } \\
\text { exam } \\
\text { (how sure } \\
\text { are you) }\end{array}$ & $\begin{array}{l}\text { Fatigue level viewing image } \\
\text { (low or high strain in } \\
\text { discerning the image) }\end{array}$ \\
\hline $1 \mathrm{a}$ & $\begin{array}{ll}\text { - } & \text { Good } \\
\text { - } & \text { Poor }\end{array}$ & \multicolumn{2}{|c|}{$\begin{array}{ll}\cdot & \text { Normal } \\
\text { - } & \text { Abnormal } \\
\text { - } & \text { Diagnostic Challenge }\end{array}$} & $\begin{array}{ll}\cdot & \text { Maxilla } \\
\text { - } & \text { Mandible } \\
\text { - } & \text { Both } \\
\text { - } & \text { Sinus } \\
\text { - } & \text { Cranial base } \\
\text { - } & \text { NA }\end{array}$ & $\begin{array}{l}\text { Excellent } \\
\text { - Good } \\
\text { - Poor } \\
\text { NA }\end{array}$ & $0--100 \%$ & Low $1-2-3-4-5$ high \\
\hline$\underline{2 \mathrm{~b}}$ & $\begin{array}{l}\text { - } \text { Good } \\
\text { - }\end{array}$ & \multicolumn{2}{|c|}{$\begin{array}{ll}\text { - } & \text { Normal } \\
\text { - Abnormal } \\
\text { - } & \text { Diagnostic Challenge }\end{array}$} & $\begin{array}{ll}\cdot & \text { Maxilla } \\
\text { - } & \text { Mandible } \\
\text { - } & \text { Both } \\
\text { - } & \text { Sinus } \\
\text { - } & \text { Cranial base } \\
\text { - } & \text { NA }\end{array}$ & $\begin{array}{ll}\text { - } & \text { Excellent } \\
\text { - } & \text { Good } \\
\text { - } & \text { Poor } \\
\text { - } & \text { NA }\end{array}$ & $0-100 \%$ & Low $1-2-3-4-5$ high \\
\hline$\underline{2 c}$ & \multicolumn{2}{|c|}{$\begin{array}{l}\text { Is there improved image clarity } \\
\text { between the images? } \\
\text { Yes no } \\
\text { * if so which is better? } \\
2 \mathrm{a} \text { or } 2 \mathrm{~b} \text { ? } \\
\text { How much improvement? } \\
\text { small improvement } \\
\text { large improvement }\end{array}$} & \multicolumn{2}{|c|}{$\begin{array}{l}\text { Are you able to discern } \\
\text { more details from the } \\
\text { one image? } \\
\text { Yes } \\
\text { No } \\
\text { Which image has more } \\
\text { detail? } \\
\begin{array}{ll}\text { 2a } & \text { 2b }\end{array}\end{array}$} & \multicolumn{3}{|c|}{ - Personal observations or comments: } \\
\hline
\end{tabular}




\section{Case 3}

\begin{tabular}{|c|c|c|c|c|c|c|}
\hline Case \# & Image Quality: & $\begin{array}{c}\text { Max } 1^{\text {st }} \text { molar } \\
\text { Is the pin in the } \\
\text { pulp? }\end{array}$ & $\begin{array}{c}\text { Mand } 1^{\text {st }} \text { molar } \\
\text { Is the pin in the } \\
\text { pulp? }\end{array}$ & $\begin{array}{l}\text { Conspicuity of } \\
\text { the image: } \\
\text { (how obvious is } \\
\text { the normaley or } \\
\text { pathology }\end{array}$ & $\begin{array}{l}\text { Confidence } \\
\text { level of } \\
\text { exam } \\
\text { (how sure } \\
\text { are you) }\end{array}$ & $\begin{array}{l}\text { Fatigue level viewing image } \\
\text { (low or high strain in } \\
\text { discerning the image) }\end{array}$ \\
\hline$\underline{3 a}$ & $\begin{array}{l}\text { - } \text { Good } \\
\text { - } \quad \text { Poor }\end{array}$ & $\begin{array}{ll}\cdot & \text { yes } \\
\cdot & \text { no } \\
\text { - } & \text { Diagnostic } \\
\text { Challenge }\end{array}$ & $\begin{array}{ll}\cdot & \text { yes } \\
\text { - } & \text { no } \\
\text { - } & \text { diagnostic } \\
\text { - } & \text { c challenge }\end{array}$ & $\begin{array}{l}\text { - Excellent } \\
\text { - Good } \\
\text { - Poor } \\
\text { NA }\end{array}$ & $0-100 \%$ & Low $1-2-3-4-5$ high \\
\hline$\underline{3 b}$ & $\begin{array}{l}\text { - } \text { Good } \\
\text { - } \quad \text { Poor }\end{array}$ & $\begin{array}{ll}\cdot & \text { yes } \\
\text { - no } & \text { nognostic } \\
\text { - } & \text { Challenge }\end{array}$ & $\begin{array}{ll}\text { - } & \text { yes } \\
\text { - } & \text { no } \\
\text { - } & \text { diagnostic } \\
\text { - } & \text { c challenge }\end{array}$ & $\begin{array}{ll}\text { - } & \text { Excellent } \\
\text { - } & \text { Good } \\
\text { - } & \text { Poor } \\
\text { - NA }\end{array}$ & $0-100 \%$ & Low $1-2-3-4-5$ high \\
\hline$\underline{3 c}$ & \multicolumn{2}{|c|}{$\begin{array}{l}\text { * Is there improved image clarity } \\
\text { between the images? } \\
\text { Yes no } \\
\text { if so which is better? } \\
3 \mathrm{a} \text { or } 3 \mathrm{~b} \text { ? } \\
\text { How much improvement? } \\
\text { small improvement } \\
\text { large improvement }\end{array}$} & $\begin{array}{l}\text { * Are you able to discern } \\
\text { more details from the } \\
\text { one image? } \\
\text { Yes } \\
\text { * Which image has more } \\
\text { detail? } \\
\text { 3a }\end{array}$ & \multicolumn{3}{|c|}{$\begin{array}{l}\text { Was the pin in the pulp? } \\
\text { Yes no can't determine } \\
\text { - Which image demonstrates that better? } \\
\text { a Personal observations or comments: }\end{array}$} \\
\hline
\end{tabular}




\section{Case 4}

\begin{tabular}{|c|c|c|c|c|c|c|c|}
\hline$\underline{\text { Case \# }}$ & Image Quality: & \multicolumn{2}{|c|}{ Anatomical structure } & $\begin{array}{l}\text { If pathology exists, } \\
\text { where is it located? }\end{array}$ & $\begin{array}{l}\text { Conspicuity of } \\
\text { the image: } \\
\text { (how obvious is } \\
\text { the normaley or } \\
\text { pathology }\end{array}$ & $\begin{array}{l}\text { Confidence } \\
\text { level of } \\
\text { exam } \\
\text { (how sure } \\
\text { are you) }\end{array}$ & $\begin{array}{l}\text { Fatigue level viewing image } \\
\text { (low or high strain in } \\
\text { discerning the image) }\end{array}$ \\
\hline 4a & $\begin{array}{ll}\text { - } & \text { Good } \\
\text { - } & \text { Poor }\end{array}$ & $\begin{array}{ll}\cdot & \text { Normal } \\
- & \text { Abnormal } \\
- & \text { Diagnostic }\end{array}$ & allenge & $\begin{array}{ll} & \text { peri implant } \\
\text { region } \\
\text { - } \\
\text { RCT tx'ed tooth } \\
\text { - Both }\end{array}$ & $\begin{array}{l}\text { - Excellent } \\
\text { - Good } \\
\text { Poor } \\
\text { - NA }\end{array}$ & $0-100 \%$ & Low 1 - 2 - 3-4 - 5 high \\
\hline$\underline{4 b}$ & $\begin{array}{ll}\text { - } & \text { Good } \\
\text { - } & \text { Poor }\end{array}$ & $\begin{array}{ll}\text { - } & \text { Normal } \\
\text { - } & \text { Abnormal } \\
\text { - } & \text { Diagnostic }\end{array}$ & allenge & $\begin{array}{ll}\text { - } & \text { peri implant } \\
\text { region } \\
\text { - } \\
\text { RCT tx'ed tooth } \\
\text { - Both }\end{array}$ & $\begin{array}{ll}\text { - } & \text { Excellent } \\
\text { - } & \text { Good } \\
\text { - Poor } \\
\text { - NA }\end{array}$ & 0 & Low $1-2-3-4-5$ high \\
\hline$\underline{4 c}$ & 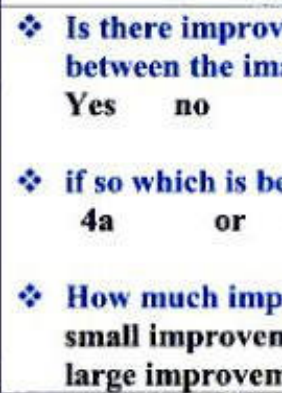 & $\begin{array}{l}\text { image clarity } \\
\text { es? } \\
\text { er? } \\
\text { b? } \\
\text { vement? } \\
\text { nt } \\
\text { t }\end{array}$ & $\begin{array}{l}* \begin{array}{c}\text { Are } \\
\text { mor } \\
\text { one } \\
\text { Yes }\end{array} \\
* \begin{array}{l}\text { Wh } \\
\text { det: } \\
4 \text { a }\end{array}\end{array}$ & $\begin{array}{l}\text { you able to discern } \\
\text { e details from the } \\
\text { image? } \\
\text { No } \\
\text { ch image has more } \\
\text { il? } \\
\text { 4b }\end{array}$ & - Personal obse & vations or con & iments: \\
\hline
\end{tabular}




\section{Case 5}

\begin{tabular}{|c|c|c|c|c|c|c|c|}
\hline Case \# & Image Quality: & \multicolumn{2}{|c|}{ Anatomical structure } & $\begin{array}{l}\text { If pathology exists, } \\
\text { where is it located? }\end{array}$ & $\begin{array}{l}\text { Conspicuity of } \\
\text { the image: } \\
\text { (how obvious is } \\
\text { the normalcy or } \\
\text { pathology }\end{array}$ & $\begin{array}{l}\text { Confidence } \\
\text { level of } \\
\text { exam } \\
\text { (how sure } \\
\text { are you) }\end{array}$ & $\begin{array}{l}\text { Fatigue level viewing image } \\
\text { (low or high strain in } \\
\text { discerning the image) }\end{array}$ \\
\hline$\underline{5 a}$ & $\begin{array}{ll}\text { - } & \text { Good } \\
\text { - } & \text { Poor }\end{array}$ & \multicolumn{2}{|c|}{$\begin{array}{ll}\text { - } & \text { Normal } \\
\text { - } & \text { Abnormal } \\
\text { - Diagnostic Challenge }\end{array}$} & $\begin{array}{l}\text { - mesial root } \\
\text { - distal root } \\
\text { - both }\end{array}$ & $\begin{array}{l}\text { - Excellent } \\
\text { - Good } \\
\text { - Poor } \\
\text { - NA }\end{array}$ & $\begin{array}{l}0-100 \% \\
\square\end{array}$ & Low $1-2-3-4-5$ high \\
\hline$\underline{5 b}$ & $\begin{array}{l}\text { - Good } \\
\text { - } \text { Poor }\end{array}$ & \multicolumn{2}{|c|}{$\begin{array}{ll}\cdot & \text { Normal } \\
\text { - } & \text { Abnormal } \\
\text { - } & \text { Diagnostic Challenge }\end{array}$} & $\begin{array}{l}\text { - mesial root } \\
\text { - distal root } \\
\text { - both }\end{array}$ & $\begin{array}{ll}\cdot & \text { Excellent } \\
\text { - } & \text { Good } \\
\text { - } & \text { Poor } \\
\text { - } & \text { NA }\end{array}$ & $0-100 \%$ & Low $1-2-3-4-5$ high \\
\hline$\underline{5 \mathrm{c}}$ & \multicolumn{2}{|c|}{$\begin{array}{l}* \text { Is there improved image clarity } \\
\text { between the images? } \\
\text { Yes no } \\
* \text { if so which is better? } \\
5 \text { a or } 5 \text { b? } \\
\text { How much improvement? } \\
\text { small improvement } \\
\text { large improvement }\end{array}$} & $\begin{array}{l}* \begin{array}{c}\text { Are } \\
\text { mot } \\
\text { one } \\
\text { Yes }\end{array} \\
\text { Wh } \\
\text { det: } \\
5 a\end{array}$ & $\begin{array}{l}\text { you able to discern } \\
\text { details from the } \\
\text { mage? } \\
\text { No } \\
\text { ch image has more } \\
\text { 5b }\end{array}$ & \multicolumn{3}{|c|}{$\begin{array}{l}\text { Can you see better visualization between the relationship } \\
\text { of the apex and RCF between the images, if so, which is better } \\
\text { or worse? } \\
\text { - 5a - better or worse } \\
\text { - 5b - better or worse } \\
\text { Personal observations or comments: }\end{array}$} \\
\hline
\end{tabular}




\section{Case 6}

\begin{tabular}{|c|c|c|c|c|c|c|c|}
\hline Case \# & Image Quality: & \multicolumn{2}{|c|}{ Anatomical structure } & $\begin{array}{l}\text { If pathology exists, } \\
\text { where is it located? }\end{array}$ & $\begin{array}{l}\text { Conspicuity of } \\
\text { the image: } \\
\text { (how obvious is } \\
\text { the normalcy or } \\
\text { pathology }\end{array}$ & $\begin{array}{c}\text { Confidence } \\
\text { level of } \\
\text { exam } \\
\text { (how sure } \\
\text { are you) }\end{array}$ & $\begin{array}{l}\text { Fatigue level viewing image } \\
\text { (low or high strain in } \\
\text { discerning the image) }\end{array}$ \\
\hline$\underline{6 a}$ & $\begin{array}{ll}\text { - } & \text { Good } \\
\text { - } & \text { Poor }\end{array}$ & \multicolumn{2}{|c|}{$\begin{array}{ll}\text { - } & \text { Normal } \\
\text { - Abnormal } \\
\text { - }\end{array}$} & $\begin{array}{l}\text { - mesial abutment } \\
\text { - Distal abutment } \\
\text { - Both }\end{array}$ & $\begin{array}{l}\text { - Excellent } \\
\text { - Good } \\
\text { - Poor } \\
\text { - NA }\end{array}$ & $0-100 \%$ & Low $1-2-3-4-5$ high \\
\hline$\underline{6 b}$ & $\begin{array}{ll}\text { - } & \text { Good } \\
\text { - } & \text { Poor }\end{array}$ & \multicolumn{2}{|c|}{$\begin{array}{ll}\cdot & \text { Normal } \\
\text { - Abnormal } \\
\text { - } & \text { Diagnostic Challenge }\end{array}$} & $\begin{array}{l}\text { - mesial abutment } \\
\text { - Distal abutment } \\
\text { - Both }\end{array}$ & $\begin{array}{ll}\text { - } & \text { Excellent } \\
\text { - } & \text { Good } \\
\text { - Poor } \\
\text { - NA }\end{array}$ & 0 & Low $1-2-3-4-5$ high \\
\hline$\underline{6 c}$ & \multicolumn{2}{|c|}{$\begin{array}{l}\text { * Is there improved image clarity } \\
\text { between the images? } \\
\text { Yes no } \\
\text { * if so which is better? } \\
6 \mathrm{a} \text { or } 6 \mathrm{~b} ? \\
* \text { How much improvement? } \\
\text { small improvement } \\
\text { large improvement }\end{array}$} & $\begin{array}{l}* \begin{array}{c}\text { Are } \\
\text { mor } \\
\text { one } \\
\text { Yes }\end{array} \\
* \begin{array}{l}\text { Wh } \\
\text { det: } \\
6 a\end{array}\end{array}$ & $\begin{array}{l}\text { you able to discern } \\
\text { e details from the } \\
\text { image? } \\
\text { No } \\
\text { ch image has more } \\
\text { il? } \\
\text { 6b }\end{array}$ & \multicolumn{3}{|c|}{ - Personal observations or comments: } \\
\hline
\end{tabular}




\section{Case 7}

\begin{tabular}{|c|c|c|c|c|c|c|c|}
\hline Case \# & Image Quality: & \multicolumn{2}{|c|}{ Anatomical structure } & $\begin{array}{l}\text { If pathology exists, } \\
\text { where is it located? }\end{array}$ & $\begin{array}{c}\text { Conspicuity of } \\
\text { the image: } \\
\text { (how obvious is } \\
\text { the normalcy or } \\
\text { pathology }\end{array}$ & $\begin{array}{l}\text { Confidence } \\
\text { level of } \\
\text { exam } \\
\text { (how sure } \\
\text { are you) }\end{array}$ & $\begin{array}{l}\text { fatigue level viewing image } \\
\text { (low or high strain in } \\
\text { discerning the image) }\end{array}$ \\
\hline$\underline{7 a}$ & $\begin{array}{ll}\text { - } & \text { Good } \\
\text { - } & \text { Poor }\end{array}$ & \multicolumn{2}{|c|}{$\begin{array}{ll}\text { - } & \text { Normal } \\
\text { - } & \text { Abnormal } \\
\text { - } & \text { Diagnostic Challenge }\end{array}$} & $\begin{array}{ll}\text { - } & \text { interprox 17-18 } \\
\text { - interprox 18-19 } \\
\text { - furcal }\end{array}$ & $\begin{array}{ll}\text { - } & \text { Excellent } \\
\text { - } & \text { Good } \\
\text { : } & \text { Poor } \\
\text { - NA }\end{array}$ & $0-100 \%$ & Low $1-2-3-4-5$ high \\
\hline$\underline{7 b}$ & $\begin{array}{l}\text { - } \text { Good } \\
\text { - } \text { Poor }\end{array}$ & \multicolumn{2}{|c|}{$\begin{array}{ll}\text { - } & \text { Normal } \\
\text { - } & \text { Abnormal } \\
\text { - } & \text { Diagnostic Challenge }\end{array}$} & $\begin{array}{ll}\text { - } & \text { interprox 17-18 } \\
\text { - } & \text { interprox 18-19 } \\
\text { - } & \text { furcal }\end{array}$ & $\begin{array}{ll}\text { - } & \text { Excellent } \\
\text { - } & \text { Good } \\
\text { - } & \text { Poor } \\
\text { - } & \text { NA }\end{array}$ & $0-100 \%$ & Low $1-2-3-4-5$ high \\
\hline$\underline{7 c}$ & \multicolumn{2}{|c|}{$\begin{array}{l}\text { Is there improved image clarity } \\
\text { between the images? } \\
\text { Yes no } \\
* \text { if so which is better? } \\
7 \text { a or } 7 \mathrm{~b} \text { ? } \\
\text { How much improvement? } \\
\text { small improvement } \\
\text { large improvement }\end{array}$} & \multicolumn{2}{|c|}{$\begin{array}{l}* \text { Are you able to discern } \\
\text { more details from the } \\
\text { one image? } \\
\text { Yes } \\
* \text { Wo } \\
\text { detail? } \\
\begin{array}{l}\text { 7a } \\
\text { ab }\end{array}\end{array}$} & \multicolumn{3}{|c|}{ - Personal observations or comments: } \\
\hline
\end{tabular}




\section{Case 8}

\begin{tabular}{|c|c|c|c|c|c|c|c|}
\hline Case \# & Image Quality: & \multicolumn{2}{|c|}{ Anatomical structure } & $\begin{array}{l}\text { If pathology exists, } \\
\text { where is it located? }\end{array}$ & $\begin{array}{l}\text { Conspicuity of } \\
\text { the image: } \\
\text { (how obvious is } \\
\text { the normaley or } \\
\text { pathology }\end{array}$ & $\begin{array}{l}\text { Confidence } \\
\text { level of } \\
\text { exam } \\
\text { (how sure } \\
\text { are you) }\end{array}$ & $\begin{array}{l}\text { Fatigue level viewing image } \\
\text { (low or high strain in } \\
\text { discerning the image) }\end{array}$ \\
\hline$\underline{8 a}$ & $\begin{array}{ll}\text { - } & \text { Good } \\
\text { - } & \text { Poor }\end{array}$ & \multicolumn{2}{|c|}{$\begin{array}{ll}\cdot & \text { Normal } \\
\text { - } & \text { Abnormal } \\
\text { - } & \text { Diagnostic Challenge }\end{array}$} & $\begin{array}{ll}\text { - } & \text { Cortical edges } \\
\text { - } & \text { Trabecular } \\
\text { region } \\
\text { - } \\
\text { - } \text { neth } \\
\end{array}$ & $\begin{array}{ll}\text { - } & \text { Excellent } \\
\text { - } & \text { Good } \\
\text { - Poor } \\
\text { - NA }\end{array}$ & $0-100 \%$ & Low $1-2-3-4-5$ high \\
\hline$\underline{8 \mathrm{~b}}$ & $\begin{array}{ll}\text { - } & \text { Good } \\
\text { - } & \text { Poor }\end{array}$ & \multicolumn{2}{|c|}{$\begin{array}{ll}\cdot & \text { Normal } \\
\text { - Abnormal } \\
\text { - Diagnostic Challenge }\end{array}$} & $\begin{array}{ll}\text { - } & \text { Cortical edges } \\
\text { - } & \text { Trabecular } \\
\text { region } \\
\text { - } \\
\text { Both } \\
\text { - } & \text { neither }\end{array}$ & $\begin{array}{ll}\text { - } & \text { Excellent } \\
\text { - } & \text { Good } \\
\text { - } & \text { Poor } \\
\text { - } & \text { NA }\end{array}$ & $0-100 \%$ & Low $1-2-3-4-5$ high \\
\hline$\underline{8 c}$ & $\begin{array}{l}* \text { Is there impro } \\
\text { between the in } \\
\text { Yes no } \\
* \text { if so which is b } \\
8 \mathrm{a} \\
* \text { How much im } \\
\text { small improve } \\
\text { large improver }\end{array}$ & $\begin{array}{l}\text { image clarity } \\
\text { es? } \\
\text { er? } \\
\text { b? } \\
\text { vement? } \\
\text { nt } \\
\text { at }\end{array}$ & \multicolumn{2}{|c|}{$\begin{array}{l}\text { Yes } \\
\text { No } \\
\text { Which image has more } \\
\text { detail? } \\
\begin{array}{l}\text { 8a } \quad 8 b \\
\text { a }\end{array}\end{array}$} & \multicolumn{3}{|c|}{$\begin{array}{l}\text { - In which image is the: } \\
\text { Cortical border clearer a } \\
\text { Trabecular bone }\end{array}$} \\
\hline
\end{tabular}




\section{Case 9}

\begin{tabular}{|c|c|c|c|c|c|c|c|}
\hline Case \# & Image Quality: & \multicolumn{2}{|c|}{ Anatomical structure } & $\begin{array}{l}\text { If pathology exists, } \\
\text { where is it located? }\end{array}$ & $\begin{array}{l}\text { Conspicuity of } \\
\text { the image: } \\
\text { (how obvious is } \\
\text { the normalcy or } \\
\text { pathology }\end{array}$ & $\begin{array}{l}\text { Confidence } \\
\text { level of } \\
\text { exam } \\
\text { (how sure } \\
\text { are you) }\end{array}$ & $\begin{array}{l}\text { Fatigue level viewing image } \\
\text { (low or high strain in } \\
\text { discerning the image) }\end{array}$ \\
\hline 9a & $\begin{array}{l}\text { - } \text { Good } \\
\text { - } \text { Poor }\end{array}$ & $\begin{array}{ll}\cdot & \text { Normal } \\
\text { - } & \text { Abnormal } \\
\text { - } & \text { Diagnostic }\end{array}$ & allenge & $\begin{array}{ll}\text { - } & \text { First molar } \\
\text { - } & \text { Second molar } \\
\text { - } & \text { Third molar }\end{array}$ & $\begin{array}{l}\text { - Excellent } \\
\text { - Good } \\
\text { - } \text { Noor } \\
\text { - }\end{array}$ & $0-100 \%$ & Low 1 - 2 - $3-4$ - 5 high \\
\hline 9b & $\begin{array}{ll}\text { - } & \text { Good } \\
\text { - } & \text { Poor }\end{array}$ & $\begin{array}{ll}\cdot & \text { Normal } \\
\text { - } & \text { Abnormal } \\
\text { - } & \text { Diagnostic }\end{array}$ & allenge & $\begin{array}{ll}\text { - } & \text { First molar } \\
\text { - } & \text { Second molar } \\
\text { - } & \text { Third molar }\end{array}$ & $\begin{array}{ll}\text { - } & \text { Excellent } \\
\text { - } & \text { Good } \\
\text { - } & \text { Poor } \\
\text { - } & \text { NA }\end{array}$ & $0-100 \%$ & Low $1-2-3-4-5$ high \\
\hline$\underline{9 c}$ & $\begin{array}{l}\text { * Is there impro } \\
\text { between the in } \\
\text { Yes no } \\
* \text { if so which is b } \\
9 \mathrm{a} \quad \text { or } \\
\text { * How much im } \\
\text { small improve } \\
\text { large improver }\end{array}$ & $\begin{array}{l}\text { image clarity } \\
\text { es? } \\
\text { er? } \\
\text { b? } \\
\text { vement? } \\
\text { it }\end{array}$ & $\begin{array}{l}* \begin{array}{c}\text { Are } \\
\text { mo } \\
\text { one } \\
\text { Yes }\end{array} \\
* \begin{array}{l}\text { Wh } \\
\text { det } \\
9 \mathrm{a}\end{array}\end{array}$ & $\begin{array}{l}\text { you able to discern } \\
\text { e details from the } \\
\text { image? } \\
\text { ch image has more } \\
\text { il? } 9 \mathrm{~b}\end{array}$ & - Personal obsc & vations or cor & ments: \\
\hline
\end{tabular}




\section{Case 10}

\begin{tabular}{|c|c|c|c|c|c|c|c|}
\hline Case \# & Image Quality: & \multicolumn{2}{|c|}{ Anatomical structure } & $\begin{array}{l}\text { If pathology exists, } \\
\text { where is it located? }\end{array}$ & $\begin{array}{l}\text { Conspicuity of } \\
\text { the image: } \\
\text { (how obvious is } \\
\text { the normalcy or } \\
\text { pathology }\end{array}$ & $\begin{array}{l}\text { Confidence } \\
\text { level of } \\
\text { exam } \\
\text { (how sure } \\
\text { are you) }\end{array}$ & $\begin{array}{l}\text { Fatigue level viewing image } \\
\text { (low or high strain in } \\
\text { discerning the image) }\end{array}$ \\
\hline$\underline{10 \mathrm{a}}$ & $\begin{array}{l}\text { - } \text { Good } \\
\text { - Poor }\end{array}$ & \multicolumn{2}{|c|}{$\begin{array}{ll}\text { - } & \text { Normal } \\
\text { - Abnormal } \\
\text { - }\end{array}$} & $\begin{array}{ll}\text { - } & \text { Central incisor } \\
\text { - Lateral incisor } \\
\text { - Both }\end{array}$ & $\begin{array}{l}\text { - Excellent } \\
\text { - Good } \\
\text { - Poor } \\
\text { - NA }\end{array}$ & $0-100 \%$ & Low $1-2-3-4-5$ high \\
\hline$\underline{10 b}$ & $\begin{array}{l}\text { - } \text { Good } \\
\text { - } \quad \text { Poor }\end{array}$ & \multicolumn{2}{|c|}{$\begin{array}{ll}\text { - } & \text { Normal } \\
\text { - } & \text { Abnormal } \\
\text { - } & \text { Diagnostic Challenge }\end{array}$} & $\begin{array}{l}\text { - Central incisor } \\
\text { - Lateral incisor } \\
\text { - Both }\end{array}$ & $\begin{array}{ll}\text { - } & \text { Excellent } \\
\text { - } & \text { Good } \\
\text { - } & \text { Poor } \\
\text { - } & \text { NA }\end{array}$ & $0-100 \%$ & Low $1-2-3-4-5$ high \\
\hline$\underline{10 \mathrm{c}}$ & \multicolumn{2}{|c|}{$\begin{array}{l}\text { Is there improved image clarity } \\
\text { between the images? } \\
\text { Yes no } \\
* \text { if so which is better? } \\
10 \mathrm{a} \text { or } 10 \mathrm{~b} \text { ? } \\
\text { How much improvement? } \\
\text { small improvement } \\
\text { large improvement }\end{array}$} & \multicolumn{2}{|c|}{$\begin{array}{l}\text { * Are you able to discern } \\
\text { more details from the } \\
\text { one image? } \\
\text { Yes } \\
\text { * Which image has more } \\
\text { detail? } \\
\begin{array}{ll}10 \mathrm{a} & 10 \mathrm{~b}\end{array}\end{array}$} & \multicolumn{3}{|c|}{ - Personal observations or comments: } \\
\hline
\end{tabular}




\section{Case 11}

\begin{tabular}{|c|c|c|c|c|c|c|c|}
\hline Case \# & Image Quality: & \multicolumn{2}{|c|}{ Anatomical structure } & $\begin{array}{l}\text { If pathology exists, } \\
\text { where is it located? }\end{array}$ & $\begin{array}{l}\text { Conspicuity of } \\
\text { the image: } \\
\text { (how obvious is } \\
\text { the normalcy or } \\
\text { pathology }\end{array}$ & $\begin{array}{l}\text { Confidence } \\
\text { level of } \\
\text { exam } \\
\text { (how sure } \\
\text { are you) }\end{array}$ & $\begin{array}{l}\text { Fatigue level viewing image } \\
\text { (low or high strain in } \\
\text { discerning the image) }\end{array}$ \\
\hline $11 \mathbf{a}$ & $\begin{array}{l}\text { - Good } \\
\text { - } \quad \text { Poor }\end{array}$ & \multicolumn{2}{|c|}{$\begin{array}{ll}\text { - } & \text { Normal } \\
\text { - } & \text { Abnormal } \\
\text { - } & \text { Diagnostic Challenge }\end{array}$} & $\begin{array}{ll}\cdot & \text { Maxilla } \\
- & \text { Mandible } \\
\text { - } & \text { Maxillary sinus } \\
\cdot & \text { Cranial base }\end{array}$ & $\begin{array}{l}\text { - Excellent } \\
\text { - Good } \\
\text { - Poor } \\
\text { NA }\end{array}$ & $0-100 \%$ & Low $1-2-3-4-5$ high \\
\hline$\underline{11 \mathrm{~b}}$ & $\begin{array}{ll}\text { - } & \text { Good } \\
\text { - } & \text { Poor }\end{array}$ & \multicolumn{2}{|c|}{$\begin{array}{ll}\text { - } & \text { Normal } \\
\text { - } & \text { Abnormal } \\
\text { - } & \text { Diagnostic Challenge }\end{array}$} & $\begin{array}{ll}\cdot & \text { Maxilla } \\
\text { - } & \text { Mandible } \\
\text { - } & \text { Maxillary sinus } \\
\text { - } & \text { Cranial base }\end{array}$ & $\begin{array}{ll}\text { - } & \text { Excellent } \\
\text { - } & \text { Good } \\
\text { - } & \text { Poor } \\
\text { - NA } & \text { NA }\end{array}$ & $0-100 \%$ & Low $1-2-3-4-5$ high \\
\hline$\underline{11 \mathrm{c}}$ & \multicolumn{2}{|c|}{$\begin{array}{l}\text { Is there improved image clarity } \\
\text { between the images? } \\
\text { Yes no } \\
* \text { if so which is better? } \\
11 \mathrm{a} \text { or } 11 \mathrm{~b} \text { ? } \\
\text { How much improvement? } \\
\text { small improvement } \\
\text { large improvement }\end{array}$} & $\begin{array}{l}* \text { Are } \\
\text { mot } \\
\text { one } \\
\text { Yes } \\
* \text { Wh } \\
\text { det: } \\
\text { 11a }\end{array}$ & $\begin{array}{l}\text { you able to discern } \\
\text { e details from the } \\
\text { image? } \\
\text { No } \\
\text { ich image has more } \\
\text { ill? } \\
\text { 11b }\end{array}$ & \multicolumn{3}{|c|}{ - Personal observations or comments: } \\
\hline
\end{tabular}




\section{Case 12}

\begin{tabular}{|c|c|c|c|c|c|c|c|}
\hline Case \# & Image Quality: & \multicolumn{2}{|c|}{ Anatomical structure } & $\begin{array}{l}\text { If pathology exists, } \\
\text { where is it located? }\end{array}$ & $\begin{array}{l}\text { Conspicuity of } \\
\text { the image: } \\
\text { (how obvious is } \\
\text { the normalcy or } \\
\text { pathology }\end{array}$ & $\begin{array}{l}\text { Confidence } \\
\text { level of } \\
\text { exam } \\
\text { (how sure } \\
\text { are you) }\end{array}$ & $\begin{array}{l}\text { Fatigue level viewing image } \\
\text { (low or high strain in } \\
\text { discerning the image) }\end{array}$ \\
\hline$\underline{12 a}$ & $\begin{array}{ll}\text { - } & \text { Good } \\
\text { - Poor }\end{array}$ & \multicolumn{2}{|c|}{$\begin{array}{ll}\cdot & \text { Normal } \\
- & \text { Abnormal } \\
\text { - } & \text { Diagnostic Challenge }\end{array}$} & $\begin{array}{l}\text { - 2nd premolar } \\
\text { - } \text { 1st premolar } \\
\text { - } \text { Canine } \\
\text { - } \\
\text { Difficult to tell }\end{array}$ & $\begin{array}{l}\text { - Excellent } \\
\text { - Good } \\
\text { - Poor } \\
\text { - NA }\end{array}$ & 0 & Low $1-2-3-4-5$ high \\
\hline$\underline{12}$ & $\begin{array}{l}\text { - } \text { Good } \\
\text { - } \text { Poor }\end{array}$ & \multicolumn{2}{|c|}{$\begin{array}{ll}\text { - } & \text { Normal } \\
\text { - } & \text { Abnormal } \\
\text { - } & \text { Diagnostic Challenge }\end{array}$} & $\begin{array}{l}\text { 2nd premolar } \\
\text { - } \text { Ist premolar } \\
\text { - Canine } \\
\text { - } \\
\text { Difficult to tell }\end{array}$ & $\begin{array}{ll}\text { - } & \text { Excellent } \\
\text { - } & \text { Good } \\
\text { - } & \text { Poor } \\
\text { - NA }\end{array}$ & $0-100 \%$ & Low $1-2-3-4-5$ high \\
\hline$\underline{12 c}$ & \multicolumn{2}{|c|}{$\begin{array}{l}\text { Is there improved image clarity } \\
\text { between the images? } \\
\text { Yes no } \\
\text { * if so which is better? } \\
12 \mathrm{a} \text { or 12b? } \\
\text { * How much improvement? } \\
\text { small improvement } \\
\text { large improvement }\end{array}$} & $\begin{array}{l}* \begin{array}{c}\text { Are } \\
\text { mor } \\
\text { one } \\
\text { Yes }\end{array} \\
* \begin{array}{l}\text { Wh } \\
\text { det: } \\
12 \mathrm{a}\end{array}\end{array}$ & $\begin{array}{l}\text { you able to discern } \\
\text { e details from the } \\
\text { image? } \\
\text { No } \\
\text { il? } \\
\text { 12b }\end{array}$ & \multicolumn{3}{|c|}{ - Personal observations or comments: } \\
\hline
\end{tabular}




\section{APPENDIX D}

\section{STATISTICAL ANALYSIS - ORIENTATION PHASE}




\section{Image Clarity and Image Detail}

Q10. Is there Iproved image clarity between images?

Q11. If so, which is better?

Q12. How much improvement?

Q13. Are you able to discern more detail from one image?

Q14. Which image has more detail?

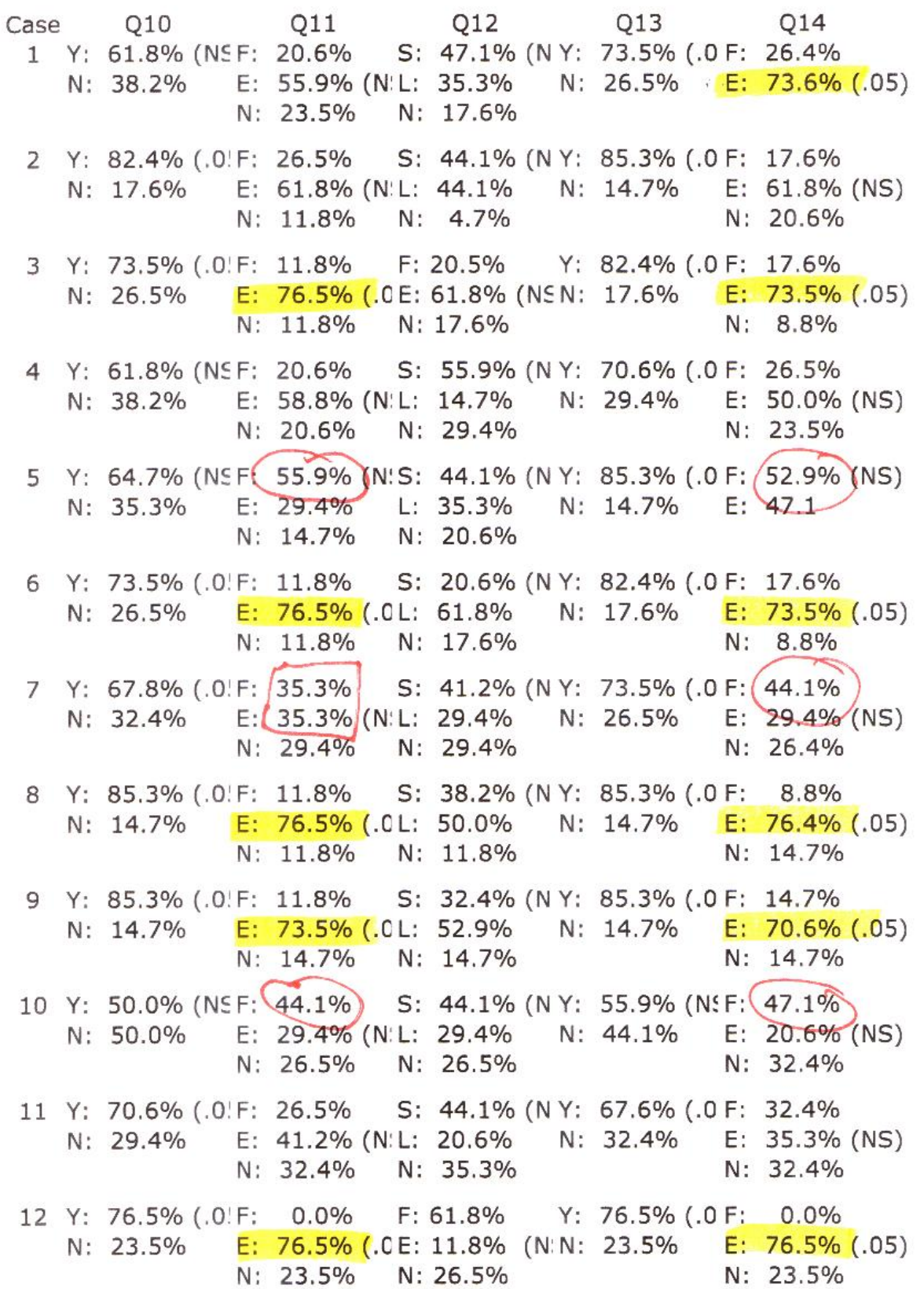


Image Quality

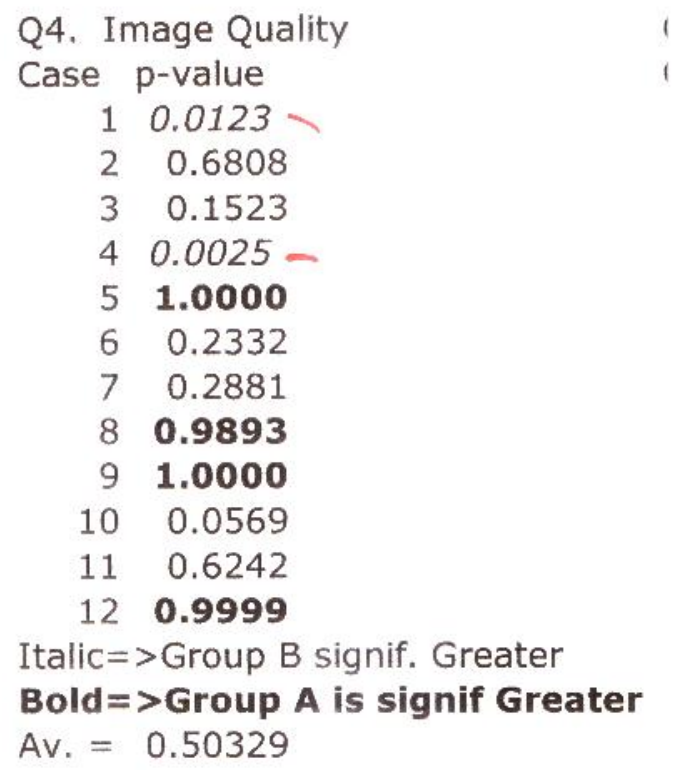


Evaluator Confidence Level and Fatigue Level

Q8. Confidence level Case

$\begin{array}{rc}1 & 0.0518 \\ 2 & 0.7578 \\ 3 & 0.0003- \\ 4 & 0.9266 \\ 5 & 0.3440 \\ 6 & 0.9994 \\ 7 & 0.5346 \\ 8 & 0.0278- \\ 9 & 0.0571 \\ 10 & 0.4925 \\ 11 & 0.07936 \\ 12 & 0.9106\end{array}$

Italic $=>$ Group B signif. Greater Bold $=>$ Group $A$ is signif Greater $A v$. $=0.4318$
Q9. Fatigue (low to high) Case

$\begin{array}{rc}1 & 0.0001- \\ 2 & 0.5770 \\ 3 & 0.0009- \\ 4 & 0.4329 \\ 5 & 0.0001- \\ 6 & 0.9811 \\ 7 & 0.2409 \\ 8 & 0.0087- \\ 9 & 0.0001- \\ 10 & 0.8819 \\ 11 & 0.5758 \\ 12 & 0.1697\end{array}$

Italic $=>$ Group B signif. Greater Bold $=>$ Group $A$ is signif Greater Av. = 0.3224 


\section{APPENDIX E}

RAW DATA - EDENTULOUS MANDIBLE PROJECT 


\begin{tabular}{|c|c|c|c|c|}
\hline \multicolumn{5}{|c|}{ Cortical Simulated Defects : 12 impulses 90 degrees } \\
\hline \multirow[b]{2}{*}{ Mandible \# } & \multirow[b]{2}{*}{ Area } & \multirow[b]{2}{*}{ Defect ID } & \multirow{2}{*}{\begin{tabular}{|c|c|} 
Conventional \\
Diameter
\end{tabular}} & \multirow{2}{*}{$\begin{array}{l}\text { Rendering } \\
\text { Diameter }\end{array}$} \\
\hline & & & & \\
\hline \multirow[t]{9}{*}{101} & A & $\mathrm{a}$ & 1.31 & 0.97 \\
\hline & & $\mathrm{b}$ & 0 & 2.32 \\
\hline & & $\mathrm{c}$ & 4.21 & 4.64 \\
\hline & LB & $\mathrm{a}$ & 1.05 & 1.17 \\
\hline & & $\mathrm{b}$ & 2.21 & 2.34 \\
\hline & & $\mathrm{c}$ & 4.12 & 4.5 \\
\hline & $\mathrm{RB}$ & $\mathrm{a}$ & 0.95 & 1.11 \\
\hline & & $b$ & 2.04 & 2.38 \\
\hline & & c & 4.16 & 4.71 \\
\hline \multirow[t]{9}{*}{102} & $A$ & $a$ & 1.12 & 1.16 \\
\hline & & $b$ & 1.56 & 1.6 \\
\hline & & C & 4.04 & 4.24 \\
\hline & LB & $a$ & 0.96 & 0.76 \\
\hline & & $b$ & 2 & 2.21 \\
\hline & & $\mathrm{c}$ & 4.11 & 4.45 \\
\hline & RB & $a$ & \begin{tabular}{|l|}
1.48 \\
\end{tabular} & 1.74 \\
\hline & & $b$ & 2.01 & 2.33 \\
\hline & & C & 3.78 & 4.32 \\
\hline \multirow[t]{9}{*}{103} & A & $a$ & 3.83 & 1.65 \\
\hline & & $b$ & 1.34 & 1.76 \\
\hline & & c & 0 & 4.32 \\
\hline & LB & $a$ & 1.92 & 2 \\
\hline & & $b$ & 2.06 & 2.07 \\
\hline & & c & 4.06 & 3.91 \\
\hline & $\mathrm{RB}$ & $a$ & 1.71 & 1.67 \\
\hline & & $b$ & 1.98 & 2.23 \\
\hline & & $\mathrm{C}$ & 4.19 & 3.9 \\
\hline \multirow[t]{9}{*}{104} & $A$ & $a$ & 1.45 & 1.45 \\
\hline & & $b$ & 2.36 & 2.07 \\
\hline & & $\mathrm{c}$ & 4.09 & 3.71 \\
\hline & LB & $a$ & 1.18 & 1.38 \\
\hline & & $b$ & 1.99 & 2.09 \\
\hline & & c & 4.18 & 4 \\
\hline & $\mathrm{RB}$ & $a$ & 1.46 & 1.56 \\
\hline & & $b$ & 1.93 & 2.18 \\
\hline & & $\mathrm{c}$ & 4.14 & 4.13 \\
\hline \multirow[t]{6}{*}{105} & A & $a$ & 1.36 & 1.05 \\
\hline & & $b$ & 1.82 & 1.84 \\
\hline & & $\mathrm{C}$ & 4.05 & 4.27 \\
\hline & LB & $a$ & 1.53 & 1.61 \\
\hline & & $b$ & 2.06 & 2.2 \\
\hline & & C & 4.14 & 4.33 \\
\hline 106 & A & $a$ & 1.43 & 0 \\
\hline
\end{tabular}




\begin{tabular}{|c|c|c|c|c|}
\hline & & $b$ & 2.02 & 2.24 \\
\hline & & $C$ & 4.18 & 4.64 \\
\hline \multirow[t]{9}{*}{107} & A & a & 1.29 & 1.27 \\
\hline & & b & 1.86 & 2.17 \\
\hline & & $C$ & 3.9 & 3.64 \\
\hline & LB & $a$ & 1.63 & 1.75 \\
\hline & & $b$ & 2.1 & 2.15 \\
\hline & & C & 4.3 & 4.1 \\
\hline & $\mathrm{RB}$ & $a$ & 1.67 & 1.89 \\
\hline & & $b$ & 2.19 & 2.35 \\
\hline & & $C$ & 4.01 & 4.22 \\
\hline \multirow[t]{9}{*}{108} & A & a & 1.36 & 1.23 \\
\hline & & $b$ & 1.87 & 1.81 \\
\hline & & $C$ & 3.65 & 3.38 \\
\hline & LB & $\mathrm{a}$ & 1.5 & 1.65 \\
\hline & & $b$ & 2.05 & 2.09 \\
\hline & & $\mathrm{C}$ & 4.16 & 4.19 \\
\hline & RB & $a$ & 14.46 & 1.46 \\
\hline & & $b$ & 1.99 & 2 \\
\hline & & C & 4.08 & 4.07 \\
\hline \multirow[t]{6}{*}{109} & A & $a$ & 1.31 & 146 \\
\hline & & $b$ & 2.08 & 1.62 \\
\hline & & C & 4.1 & 4.57 \\
\hline & $\mathrm{RB}$ & $a$ & 1.38 & 1.61 \\
\hline & & $b$ & 1.97 & 2.22 \\
\hline & & $C$ & 3.9 & 4.33 \\
\hline \multirow[t]{9}{*}{110} & A & $a$ & 0.87 & 0.98 \\
\hline & & $b$ & 1.64 & 1.96 \\
\hline & & $C$ & 4.17 & 4.03 \\
\hline & LB & $a$ & 1.5 & 1.41 \\
\hline & & $b$ & 2.07 & 1.95 \\
\hline & & $C$ & 4.18 & 4.08 \\
\hline & $\mathrm{RB}$ & $a$ & 1.68 & 1.64 \\
\hline & & $b$ & 2.12 & 2.17 \\
\hline & & $C$ & 4.22 & 4.36 \\
\hline \multirow[t]{6}{*}{111} & A & $a$ & 1.45 & 1.79 \\
\hline & & $b$ & 2.09 & 1.39 \\
\hline & & $C$ & 4.13 & 4.64 \\
\hline & LB & $a$ & 1.46 & 1.48 \\
\hline & & $b$ & 1.78 & 0 \\
\hline & & $C$ & 3.8 & 3.7 \\
\hline \multirow[t]{6}{*}{112} & A & $a$ & 1.48 & 1.23 \\
\hline & & $b$ & 1.79 & 1.75 \\
\hline & & $C$ & 3.93 & 3.54 \\
\hline & LB & a & 1.51 & 1.34 \\
\hline & & $b$ & 1.95 & 1.87 \\
\hline & & C & 4.12 & 3.57 \\
\hline
\end{tabular}




\begin{tabular}{|c|c|c|c|c|}
\hline & RB & a & 1.57 & 1.45 \\
\hline & & $b$ & 2.01 & 1.95 \\
\hline & & C & 4.01 & 3.52 \\
\hline \multirow[t]{6}{*}{113} & A & a & 1.43 & 1.06 \\
\hline & & $b$ & 1.78 & 1.87 \\
\hline & & $C$ & 3.83 & 3.49 \\
\hline & RB & $a$ & 1.52 & 1.49 \\
\hline & & b & 1.76 & 1.69 \\
\hline & & C & 3.97 & 3.89 \\
\hline \multirow[t]{6}{*}{114} & LB & $a$ & 1.48 & 1.7 \\
\hline & & $b$ & 2.09 & 2.15 \\
\hline & & C & 4.17 & 4.19 \\
\hline & RB & $a$ & 1.51 & 1.7 \\
\hline & & $b$ & 1.71 & 1.58 \\
\hline & & $\mathrm{C}$ & 4.2 & 4.12 \\
\hline \multirow[t]{9}{*}{115} & A & a & 1.25 & 0 \\
\hline & & $b$ & 1.56 & 0 \\
\hline & & $C$ & 3.96 & 3.15 \\
\hline & LB & a & 1.53 & 1.63 \\
\hline & & b & 2.08 & 2 \\
\hline & & C & 3.94 & 4 \\
\hline & $\mathrm{RB}$ & $a$ & 1.54 & 1.62 \\
\hline & & $b$ & 2.18 & 2.07 \\
\hline & & C & 4.04 & 4.11 \\
\hline \multirow[t]{3}{*}{116} & A & $a$ & 1.54 & 1.4 \\
\hline & & $b$ & 2.07 & 0 \\
\hline & & C & 4.31 & 4 \\
\hline \multirow[t]{9}{*}{117} & A & a & 1.64 & 1.65 \\
\hline & & $b$ & 1.99 & 1.78 \\
\hline & & $\mathrm{C}$ & 3.78 & 4.05 \\
\hline & LB & a & 1.49 & 0.88 \\
\hline & & $b$ & 1.93 & 2.01 \\
\hline & & C & 4.04 & 4.04 \\
\hline & $\mathrm{RB}$ & $a$ & 1.39 & 0 \\
\hline & & b & 2.1 & 0 \\
\hline & & C & 4.16 & 4.26 \\
\hline \multirow[t]{3}{*}{118} & A & a & 1.38 & 1.3 \\
\hline & & $b$ & $\begin{array}{l}1.7 \\
\end{array}$ & 2.19 \\
\hline & & C & 3.88 & 4.22 \\
\hline \multirow[t]{8}{*}{119} & A & $a$ & 1.53 & 1.39 \\
\hline & & $b$ & 2.06 & 2 \\
\hline & & C & 3.64 & 3.46 \\
\hline & LB & $a$ & 1.34 & 1.55 \\
\hline & & b & 2.03 & 1.91 \\
\hline & & $C$ & 4.14 & 4.02 \\
\hline & RB & a & 1.2 & 0.98 \\
\hline & & b & 2.15 & 1.35 \\
\hline
\end{tabular}




\begin{tabular}{|c|c|c|c|c|}
\hline & & C & 4.11 & 4.16 \\
\hline \multirow[t]{3}{*}{120} & A & $a$ & 0 & 0.86 \\
\hline & & $\mathrm{b}$ & 2.05 & 1.63 \\
\hline & & C & 3.48 & 2.84 \\
\hline \multirow[t]{6}{*}{121} & A & $a$ & 1.66 & 1.69 \\
\hline & & $b$ & 2.19 & 2.18 \\
\hline & & C & 4.39 & 4.25 \\
\hline & LB & $a$ & 1.57 & 1.72 \\
\hline & & $b$ & 1.97 & 2.09 \\
\hline & & C & 2.87 & 4.09 \\
\hline \multirow[t]{6}{*}{122} & LB & $a$ & 1.64 & 1.73 \\
\hline & & $b$ & 2.07 & 2.1 \\
\hline & & C & 4.3 & 4.39 \\
\hline & RB & $a$ & 1.58 & 1.58 \\
\hline & & $b$ & 2.18 & 2.24 \\
\hline & & C & 4.24 & 4.13 \\
\hline \multirow[t]{9}{*}{123} & A & $a$ & 1.53 & 1.6 \\
\hline & & $\mathrm{b}$ & 1.95 & 2.19 \\
\hline & & C & 4.24 & 4.12 \\
\hline & LB & $a$ & 1.39 & 1.58 \\
\hline & & $b$ & 2.06 & 2.21 \\
\hline & & $\mathrm{C}$ & \begin{tabular}{|l|}
4.02 \\
\end{tabular} & 3.94 \\
\hline & $\mathrm{RB}$ & $a$ & 1.61 & 1.35 \\
\hline & & $b$ & 1.92 & 1.94 \\
\hline & & C & 4.14 & 3.98 \\
\hline \multirow[t]{3}{*}{124} & A & $a$ & 1.66 & 1.57 \\
\hline & & $b$ & 1.98 & 2.2 \\
\hline & & $C$ & 4.05 & 4.18 \\
\hline \multirow[t]{6}{*}{125} & A & $a$ & 1.63 & 1.79 \\
\hline & & $b$ & 2.07 & 2.13 \\
\hline & & C & 3.42 & 4.35 \\
\hline & LB & $a$ & 1.88 & 1.92 \\
\hline & & $b$ & 2.19 & 2.21 \\
\hline & & C & 4.2 & 4.44 \\
\hline \multirow[t]{6}{*}{126} & A & $a$ & 1.41 & 1.25 \\
\hline & & $b$ & 2.25 & 2.27 \\
\hline & & $\mathrm{C}$ & 4.21 & 3.68 \\
\hline & $\mathrm{RB}$ & $a$ & 1.6 & 1.32 \\
\hline & & $b$ & 2.07 & 2.1 \\
\hline & & C & 4.27 & 4.13 \\
\hline \multirow[t]{6}{*}{127} & $A$ & $a$ & 1.56 & 1.72 \\
\hline & & $b$ & 1.89 & 2 \\
\hline & & C & 4.2 & 4.13 \\
\hline & LB & $a$ & 1.64 & 1.62 \\
\hline & & $b$ & 2.04 & 2.11 \\
\hline & & C & $\begin{array}{l}4.1 \\
\end{array}$ & 3.83 \\
\hline 128 & A & a & 1.42 & 1.52 \\
\hline
\end{tabular}




\begin{tabular}{|c|c|c|c|c|}
\hline & & $b$ & 1.84 & 2.12 \\
\hline & & C & 4.08 & 4.69 \\
\hline & LB & a & 1.69 & 1.87 \\
\hline & & $b$ & 2.21 & 2.27 \\
\hline & & $\mathrm{C}$ & 4.2 & 4.32 \\
\hline \multirow[t]{6}{*}{129} & A & $a$ & 1.46 & 1.6 \\
\hline & & $b$ & 2.12 & 2.3 \\
\hline & & C & 3.82 & 4.21 \\
\hline & $\mathrm{RB}$ & $a$ & 1.62 & 1.74 \\
\hline & & $b$ & 2.17 & 2.29 \\
\hline & & C & 4.16 & 4.15 \\
\hline \multirow[t]{3}{*}{130} & A & a & 1.68 & 1.69 \\
\hline & & $b$ & 2.12 & 2.27 \\
\hline & & C & 3.52 & 3.78 \\
\hline \multirow[t]{3}{*}{131} & A & $a$ & 1.6 & 1.57 \\
\hline & & $b$ & 2.14 & 2.13 \\
\hline & & $\mathrm{C}$ & 4.11 & 4.32 \\
\hline \multirow[t]{6}{*}{132} & A & $a$ & 1.7 & 1.51 \\
\hline & & $b$ & 2.19 & 2.28 \\
\hline & & $C$ & 3.99 & 4.17 \\
\hline & $\mathrm{RB}$ & $a$ & 1.56 & 1.88 \\
\hline & & $\mathrm{b}$ & 2.09 & 2.34 \\
\hline & & C & 4.89 & 4.88 \\
\hline \multirow[t]{3}{*}{133} & A & $a$ & 1.45 & 1.3 \\
\hline & & $b$ & 2.13 & 1.79 \\
\hline & & C & 4.34 & 4.23 \\
\hline \multirow[t]{3}{*}{134} & A & $a$ & 1.42 & 1.53 \\
\hline & & $b$ & 2.06 & 2.01 \\
\hline & & $\mathrm{C}$ & 3.47 & 3.92 \\
\hline \multirow[t]{9}{*}{135} & A & $a$ & 1.52 & 1.46 \\
\hline & & $b$ & 1.99 & 2.14 \\
\hline & & $\mathrm{C}$ & 3.98 & 4.04 \\
\hline & LB & $a$ & 1.41 & 1.79 \\
\hline & & $b$ & 1.97 & 2.28 \\
\hline & & C & 4.06 & 4.42 \\
\hline & RB & $a$ & 1.42 & 1.33 \\
\hline & & $b$ & 2.03 & 2.14 \\
\hline & & C & 3.85 & 4.05 \\
\hline \multirow[t]{9}{*}{136} & A & $a$ & 1.77 & 1.5 \\
\hline & & $b$ & 2.02 & 2.05 \\
\hline & & $\mathrm{C}$ & 4.21 & 4.08 \\
\hline & LB & $a$ & 1.49 & 1.58 \\
\hline & & $b$ & 2.21 & 2.16 \\
\hline & & C & 3.77 & 3.89 \\
\hline & $\mathrm{RB}$ & $a$ & 1.67 & 1.63 \\
\hline & & $b$ & 2.06 & 2.28 \\
\hline & & $\mathrm{C}$ & 4.06 & 4.15 \\
\hline
\end{tabular}




\begin{tabular}{|r|r|r|r|r|}
\hline 137 & $\mathrm{~A}$ & $\mathrm{a}$ & 1.56 & 1.74 \\
\hline & & $\mathrm{b}$ & 2.02 & 2.27 \\
\hline & & $\mathrm{C}$ & 4.05 & 3.92 \\
\hline & $\mathrm{A}$ & $\mathrm{a}$ & 1.63 & 1.59 \\
\hline & & $\mathrm{b}$ & 2.05 & 2.11 \\
\hline & & $\mathrm{C}$ & 4.13 & 4.11 \\
\hline & $\mathrm{A}$ & $\mathrm{a}$ & 1.47 & 1.57 \\
\hline & & $\mathrm{b}$ & 2.01 & 2 \\
\hline & & $\mathrm{C}$ & 4.17 & 3.98 \\
\hline & $\mathrm{RB}$ & $\mathrm{a}$ & 1.5 & 1.49 \\
\hline & & $\mathrm{b}$ & 2.1 & 2.3 \\
\hline & & $\mathrm{C}$ & 4.28 & 4.19 \\
\hline & $\mathrm{A}$ & $\mathrm{a}$ & 1.58 & 1.81 \\
\hline & & $\mathrm{b}$ & 2.05 & 2.21 \\
\hline & & $\mathrm{C}$ & 4.28 & 4.15 \\
\hline
\end{tabular}

\section{Cortical Simulated Defects: 12 impulses +10 degrees}

\begin{tabular}{|c|c|c|c|c|}
\hline \multirow[b]{2}{*}{ Mandible \# } & \multirow[b]{2}{*}{ Area } & \multirow[b]{2}{*}{ Defect ID } & Conventional & \multirow{2}{*}{$\frac{\text { Rendering }}{\text { Diameter }}$} \\
\hline & & & Diameter & \\
\hline \multirow[t]{9}{*}{101} & $A$ & $a$ & 1.19 & 0.97 \\
\hline & & $b$ & 1.94 & 2.32 \\
\hline & & $\mathrm{C}$ & 3.98 & 4.64 \\
\hline & LB & $a$ & 1.01 & 1.18 \\
\hline & & $\mathrm{b}$ & 2.09 & 2.36 \\
\hline & & c & 3.73 & 4.81 \\
\hline & RB & $a$ & 1.18 & 1.22 \\
\hline & & $\mathrm{b}$ & 1.95 & 2.3 \\
\hline & & C & 4.15 & 4.75 \\
\hline \multirow[t]{9}{*}{102} & A & $\mathrm{a}$ & 1.66 & 0.89 \\
\hline & & $\mathrm{b}$ & 1.66 & 1.55 \\
\hline & & C & 3.86 & 3.87 \\
\hline & LB & $a$ & 1.13 & 1.03 \\
\hline & & $\mathrm{b}$ & 2.11 & 2.19 \\
\hline & & c & 4.25 & 4.23 \\
\hline & RB & $\mathrm{a}$ & 1.67 & 1.42 \\
\hline & & $b$ & 2.26 & 2.16 \\
\hline & & $\mathrm{C}$ & 4.04 & 4.86 \\
\hline \multirow[t]{8}{*}{103} & $A$ & $a$ & 0 & 0 \\
\hline & & $\mathrm{b}$ & 1.93 & 1.89 \\
\hline & & $\mathrm{C}$ & 3.83 & 1.05 \\
\hline & LB & $\mathrm{a}$ & 1.6 & 1.67 \\
\hline & & $\mathrm{b}$ & 1.95 & 2.22 \\
\hline & & C & 4.09 & 4.33 \\
\hline & RB & a & 2.21 & 2.08 \\
\hline & & $b$ & 1.89 & 1.65 \\
\hline
\end{tabular}




\begin{tabular}{|c|c|c|c|c|}
\hline & & $\mathrm{C}$ & 4.32 & 4.25 \\
\hline \multirow[t]{9}{*}{104} & A & $a$ & 2.12 & 2.01 \\
\hline & & $b$ & 2.32 & 1.85 \\
\hline & & C & 4.16 & 3.94 \\
\hline & LB & $a$ & 1.17 & 1.7 \\
\hline & & $b$ & 2.11 & 2.25 \\
\hline & & $\mathrm{C}$ & 3.89 & 3.95 \\
\hline & RB & $a$ & 1.61 & 1.62 \\
\hline & & $b$ & 1.73 & 2.2 \\
\hline & & C & 3.87 & 4.03 \\
\hline \multirow[t]{6}{*}{105} & A & $a$ & 1.44 & 1.45 \\
\hline & & $b$ & 1.87 & 2 \\
\hline & & $\mathrm{C}$ & 4.04 & 4.4 \\
\hline & LB & $a$ & 1.72 & 1.87 \\
\hline & & $b$ & 2.22 & 2.28 \\
\hline & & C & 4.27 & 4.07 \\
\hline \multirow[t]{3}{*}{106} & A & $a$ & 0 & 0 \\
\hline & & $b$ & 2.57 & 1.84 \\
\hline & & C & 4.38 & 4.04 \\
\hline \multirow[t]{9}{*}{107} & A & $a$ & 1.68 & 1.5 \\
\hline & & $b$ & 2.18 & 2.27 \\
\hline & & C & 4.05 & 4.32 \\
\hline & LB & $a$ & 1.5 & 1.7 \\
\hline & & $b$ & 2.04 & 1.97 \\
\hline & & C & 3.85 & 3.87 \\
\hline & RB & $a$ & 1.59 & 2.15 \\
\hline & & $b$ & 2.1 & 2.28 \\
\hline & & C & 3.95 & 4.4 \\
\hline \multirow[t]{9}{*}{108} & A & $a$ & 1.58 & 0 \\
\hline & & $b$ & 2.72 & 2.51 \\
\hline & & C & 4 & 3.87 \\
\hline & LB & $a$ & 1.78 & 1.36 \\
\hline & & $b$ & 2.13 & 2.54 \\
\hline & & C & 3.86 & 3.82 \\
\hline & RB & $a$ & 1.42 & 1.16 \\
\hline & & $b$ & 2.41 & 2.33 \\
\hline & & C & 4.31 & 4.15 \\
\hline \multirow[t]{6}{*}{109} & A & $a$ & 1.48 & 1.6 \\
\hline & & $b$ & 2.06 & 2.04 \\
\hline & & C & 4.16 & 4.58 \\
\hline & RB & $a$ & 1.65 & 1.76 \\
\hline & & $b$ & 2 & 2.19 \\
\hline & & $\mathrm{C}$ & 3.56 & 4.08 \\
\hline \multirow[t]{4}{*}{110} & A & $a$ & 1.55 & 0.78 \\
\hline & & $b$ & 1.81 & 1.91 \\
\hline & & $\mathrm{C}$ & 4.21 & 4.4 \\
\hline & LB & $a$ & 1.61 & 1.71 \\
\hline
\end{tabular}




\begin{tabular}{|c|c|c|c|c|}
\hline & & $b$ & 2.16 & 2.13 \\
\hline & & C & 4.21 & 4.19 \\
\hline & RB & a & 1.66 & 1.64 \\
\hline & & $b$ & 2.08 & 2.21 \\
\hline & & C & 4.1 & 4.24 \\
\hline \multirow[t]{6}{*}{111} & A & $a$ & 1.31 & 1.66 \\
\hline & & $b$ & 2.03 & 2.21 \\
\hline & & $\mathrm{C}$ & 3.96 & 4.28 \\
\hline & LB & $a$ & 1.45 & 1.51 \\
\hline & & $b$ & 2.11 & 2.14 \\
\hline & & $C$ & 4.14 & 3.84 \\
\hline \multirow[t]{9}{*}{112} & A & a & 1.55 & 1.28 \\
\hline & & $b$ & 1.44 & 1.59 \\
\hline & & C & 3.89 & 3.61 \\
\hline & LB & $a$ & 1.23 & 1.53 \\
\hline & & $b$ & 1.97 & 1.82 \\
\hline & & $\mathrm{C}$ & 4.09 & 3.76 \\
\hline & RB & $a$ & 1.67 & 1.44 \\
\hline & & $b$ & 2.04 & 1.99 \\
\hline & & C & 4.09 & 3.92 \\
\hline \multirow[t]{6}{*}{113} & A & $\mathrm{a}$ & 1.86 & 0.96 \\
\hline & & $b$ & 1.46 & 1.64 \\
\hline & & $\mathrm{C}$ & 3.5 & 3.46 \\
\hline & RB & $a$ & 1.74 & 1.76 \\
\hline & & $b$ & 2.23 & 1.79 \\
\hline & & $C$ & 4.09 & 4.17 \\
\hline \multirow[t]{6}{*}{114} & LB & $a$ & 1.47 & 1.8 \\
\hline & & $b$ & 2.02 & 2.13 \\
\hline & & $\mathrm{C}$ & 4.14 & 4.16 \\
\hline & $\mathrm{RB}$ & $a$ & 1.58 & 1.75 \\
\hline & & $b$ & 1.58 & 1.96 \\
\hline & & $C$ & 4.21 & 4.13 \\
\hline \multirow[t]{9}{*}{115} & A & $a$ & 1.51 & 0 \\
\hline & & $b$ & 2.03 & 0 \\
\hline & & C & 3.82 & 3.65 \\
\hline & LB & $\mathrm{a}$ & 1.48 & 1.21 \\
\hline & & $b$ & 1.99 & 2.15 \\
\hline & & $\mathrm{C}$ & 3.83 & 4.14 \\
\hline & RB & $a$ & 1.29 & 1.46 \\
\hline & & $b$ & 2.02 & 1.99 \\
\hline & & $C$ & 3.97 & 3.99 \\
\hline \multirow[t]{3}{*}{116} & A & $a$ & 1.62 & 1.67 \\
\hline & & $b$ & 2.05 & 1.32 \\
\hline & & C & 4.13 & 4.13 \\
\hline \multirow[t]{3}{*}{117} & A & $a$ & 0 & 0 \\
\hline & & $b$ & 0 & 1.79 \\
\hline & & C & 4.46 & 4.47 \\
\hline
\end{tabular}




\begin{tabular}{|c|c|c|c|c|}
\hline & LB & a & 1.59 & 1.28 \\
\hline & & $b$ & 2.1 & 1.98 \\
\hline & & C & 4.19 & 4.15 \\
\hline & RB & a & 0 & 0 \\
\hline & & $b$ & 1.38 & 4.05 \\
\hline & & C & 3.99 & 0 \\
\hline \multirow[t]{3}{*}{118} & A & $a$ & 1.26 & 1.37 \\
\hline & & b & 2 & 2.23 \\
\hline & & C & 3.87 & 4.13 \\
\hline \multirow[t]{9}{*}{119} & A & $a$ & 1.51 & 1.23 \\
\hline & & b & 2.17 & 1.84 \\
\hline & & C & 4.07 & 3.65 \\
\hline & LB & $a$ & 1.59 & 1.46 \\
\hline & & $b$ & 2.16 & 2.33 \\
\hline & & C & 4.14 & 4.15 \\
\hline & RB & a & 1.65 & 1.39 \\
\hline & & $b$ & 2.39 & 1.43 \\
\hline & & $C$ & 4.24 & 4 \\
\hline \multirow[t]{3}{*}{120} & A & a & 1.53 & 0 \\
\hline & & b & 1.92 & 2.12 \\
\hline & & C & 3.95 & 3.9 \\
\hline \multirow[t]{6}{*}{121} & A & a & 1.58 & 1.73 \\
\hline & & $b$ & 2.24 & 2.39 \\
\hline & & C & 4.17 & 3.47 \\
\hline & LB & a & 1.45 & 1.71 \\
\hline & & b & 1.92 & 2.18 \\
\hline & & C & 4.1 & 4.23 \\
\hline \multirow[t]{6}{*}{122} & LB & a & 1.53 & 1.64 \\
\hline & & $b$ & 2.23 & 2.41 \\
\hline & & C & 4.47 & 4.53 \\
\hline & RB & a & 1.62 & 1.79 \\
\hline & & b & 2.24 & 2.25 \\
\hline & & C & 3.93 & 3.78 \\
\hline \multirow[t]{9}{*}{123} & A & $a$ & 1.94 & 2.06 \\
\hline & & $b$ & 2.21 & 2.25 \\
\hline & & C & 4.89 & 4.98 \\
\hline & LB & a & 1.78 & 1.45 \\
\hline & & $b$ & 2.09 & 2.28 \\
\hline & & C & 4.2 & 4.25 \\
\hline & RB & $\mathrm{a}$ & 1.48 & 1.12 \\
\hline & & $b$ & 1.9 & 1.55 \\
\hline & & C & 4.34 & 4.31 \\
\hline \multirow[t]{3}{*}{124} & A & a & 1.69 & 1.62 \\
\hline & & $b$ & 1.98 & 2.04 \\
\hline & & C & 3.98 & 4.24 \\
\hline \multirow[t]{2}{*}{125} & A & $a$ & 1.46 & 1.62 \\
\hline & & b & 1.9 & 2.04 \\
\hline
\end{tabular}




\begin{tabular}{|c|c|c|c|c|}
\hline & & C & 3.24 & 3.5 \\
\hline & LB & $a$ & 1.75 & 1.77 \\
\hline & & b & 2.15 & 2.31 \\
\hline & & C & 4.06 & 4.32 \\
\hline \multirow[t]{6}{*}{126} & A & $a$ & 1.42 & 1.37 \\
\hline & & $b$ & 2.19 & 1.98 \\
\hline & & C & 4.35 & 4.31 \\
\hline & RB & a & 1.93 & 1.66 \\
\hline & & b & 2.46 & 2.02 \\
\hline & & C & 4.79 & 4.71 \\
\hline \multirow[t]{6}{*}{127} & A & a & 1.65 & 1.58 \\
\hline & & $b$ & 2.26 & 2.22 \\
\hline & & $C$ & 4.8 & 4.52 \\
\hline & LB & $a$ & 1.38 & 1.33 \\
\hline & & $b$ & 2.26 & 2.17 \\
\hline & & C & 3.98 & 3.87 \\
\hline \multirow[t]{6}{*}{128} & A & $a$ & 1.6 & 1.55 \\
\hline & & $b$ & 2.16 & 1.99 \\
\hline & & C & 3.49 & 4.24 \\
\hline & LB & a & 1.65 & 1.78 \\
\hline & & $b$ & 2.1 & 2.37 \\
\hline & & C & 4.12 & 4.46 \\
\hline \multirow[t]{6}{*}{129} & A & $\mathrm{a}$ & 1.66 & 1.57 \\
\hline & & $b$ & 2 & 2.1 \\
\hline & & $\mathrm{C}$ & 4.07 & 4.23 \\
\hline & RB & $a$ & 1.45 & 1.83 \\
\hline & & $b$ & 2.06 & 2.11 \\
\hline & & C & 4.28 & 4.23 \\
\hline \multirow[t]{3}{*}{130} & A & $a$ & 1.48 & 1.55 \\
\hline & & $b$ & 1.86 & 2.3 \\
\hline & & C & 4.11 & 4.32 \\
\hline \multirow[t]{3}{*}{131} & A & $a$ & 1.79 & 1.57 \\
\hline & & $b$ & 2.07 & 1.98 \\
\hline & & C & 4.33 & 4.27 \\
\hline \multirow[t]{6}{*}{132} & A & $a$ & 1.46 & 1.64 \\
\hline & & $b$ & 2 & 1.97 \\
\hline & & C & 4.14 & 4.16 \\
\hline & $\mathrm{RB}$ & a & 1.52 & 1.7 \\
\hline & & $b$ & 1.95 & 2.14 \\
\hline & & $\mathrm{C}$ & 4.81 & 4.8 \\
\hline \multirow[t]{3}{*}{133} & A & $a$ & 1.57 & 1.77 \\
\hline & & $b$ & 1.97 & 2.15 \\
\hline & & $C$ & 4.3 & 4.45 \\
\hline \multirow[t]{3}{*}{134} & A & $a$ & 1.72 & 1.71 \\
\hline & & $b$ & 2.24 & 2 \\
\hline & & C & 4.36 & 4.3 \\
\hline 135 & A & a & 1.52 & 1.61 \\
\hline
\end{tabular}




\begin{tabular}{|c|c|c|c|c|}
\hline & & b & 1.93 & 2.2 \\
\hline & & c & 3.95 & 4.36 \\
\hline & LB & a & 1.38 & 1.68 \\
\hline & & b & 2.07 & 2.27 \\
\hline & & C & 4.07 & 4.36 \\
\hline & $\mathrm{RB}$ & $a$ & 1.5 & 1.54 \\
\hline & & $b$ & 2.02 & 2.18 \\
\hline & & c & 3.88 & 3.79 \\
\hline \multirow[t]{9}{*}{136} & A & a & 1.61 & 1.32 \\
\hline & & $b$ & 2.16 & 2 \\
\hline & & $\mathrm{C}$ & 4.02 & 3.97 \\
\hline & LB & $\mathrm{a}$ & 1.7 & 1.54 \\
\hline & & $b$ & 2.36 & 1.96 \\
\hline & & $\mathrm{C}$ & 3.93 & 4.04 \\
\hline & RB & $a$ & 1.53 & 1.78 \\
\hline & & $b$ & 2.09 & 2.41 \\
\hline & & c & 4.04 & 4.34 \\
\hline \multirow[t]{3}{*}{137} & A & $a$ & 1.42 & 1.47 \\
\hline & & $b$ & 2.24 & 2.08 \\
\hline & & c & 4.23 & 4.34 \\
\hline \multirow[t]{3}{*}{138} & A & $a$ & 1.65 & 1.53 \\
\hline & & $b$ & 2 & 1.94 \\
\hline & & $\mathrm{C}$ & 4.36 & 4.23 \\
\hline \multirow[t]{6}{*}{139} & A & a & 1.64 & 1.62 \\
\hline & & $b$ & 2.21 & 2.33 \\
\hline & & C & 4.17 & 4.29 \\
\hline & $\mathrm{RB}$ & $a$ & 1.62 & 1.36 \\
\hline & & b & 2.17 & 2.11 \\
\hline & & $\mathrm{C}$ & 4.03 & 3.96 \\
\hline \multirow[t]{3}{*}{140} & A & $a$ & 1.73 & 1.82 \\
\hline & & b & 2.15 & 2.25 \\
\hline & & C & 4.36 & 4.27 \\
\hline
\end{tabular}

\begin{tabular}{|c|c|c|c|c|}
\hline \multicolumn{5}{|c|}{ Cortical Simulated Defects: 12 impulses +20 degrees } \\
\hline \multirow[b]{2}{*}{ Mandible \# } & \multirow[b]{2}{*}{ Area } & \multirow[b]{2}{*}{ Defect ID } & Conventional & \multirow{2}{*}{\begin{tabular}{|l|} 
Rendering \\
Diameter \\
\end{tabular}} \\
\hline & & & Diameter & \\
\hline \multirow[t]{9}{*}{101} & $\mathrm{~A}$ & $a$ & 1.11 & 1.14 \\
\hline & & $\mathrm{b}$ & 0 & 2.17 \\
\hline & & $\mathrm{C}$ & 4 & 5.25 \\
\hline & LB & $a$ & 1.24 & 1.21 \\
\hline & & $\mathrm{b}$ & 1.92 & 2.31 \\
\hline & & $\mathrm{c}$ & 3.92 & 4.7 \\
\hline & $\mathrm{RB}$ & $\mathrm{a}$ & 1.38 & 1.55 \\
\hline & & $\mathrm{b}$ & 2.28 & 2.32 \\
\hline & & $\mathrm{c}$ & 4.61 & 5.67 \\
\hline
\end{tabular}




\begin{tabular}{|c|c|c|c|c|}
\hline \multirow[t]{9}{*}{102} & A & $\mathrm{a}$ & 0 & 0.86 \\
\hline & & $b$ & 0 & 1.42 \\
\hline & & $\mathrm{C}$ & 3.3 & 3.21 \\
\hline & LB & $\mathrm{a}$ & 1.02 & 0.52 \\
\hline & & $b$ & 2.05 & 1.98 \\
\hline & & $\mathrm{C}$ & 4.1 & 4.25 \\
\hline & $\mathrm{RB}$ & $a$ & 1.48 & 0 \\
\hline & & $\mathrm{b}$ & 2.19 & 1.23 \\
\hline & & $\mathrm{C}$ & 3.98 & 5.04 \\
\hline \multirow[t]{9}{*}{103} & A & $a$ & 1.84 & 2.02 \\
\hline & & $b$ & 0 & 4.37 \\
\hline & & C & 4.64 & 0 \\
\hline & LB & $a$ & 1.75 & 1.77 \\
\hline & & $b$ & 2.04 & 2.45 \\
\hline & & $\mathrm{C}$ & 4.32 & 4.5 \\
\hline & RB & $a$ & 1.84 & 1.63 \\
\hline & & $b$ & 2.42 & 2.24 \\
\hline & & C & 4.63 & 4.85 \\
\hline \multirow[t]{9}{*}{104} & A & $a$ & 0 & 0 \\
\hline & & $b$ & 2.01 & 1.91 \\
\hline & & $\mathrm{C}$ & 4.47 & 4.21 \\
\hline & LB & $a$ & 0 & 1.65 \\
\hline & & $b$ & 2.28 & 2.55 \\
\hline & & $\mathrm{C}$ & 4.34 & 4.29 \\
\hline & $\mathrm{RB}$ & $a$ & 1.52 & 1.31 \\
\hline & & $b$ & 2.06 & 1.95 \\
\hline & & C & 4.32 & 3.86 \\
\hline \multirow[t]{6}{*}{105} & A & $a$ & 1.25 & 1.4 \\
\hline & & $b$ & 1.63 & 1.7 \\
\hline & & $\mathrm{C}$ & 3.89 & 4.01 \\
\hline & LB & $a$ & 1.46 & 1.92 \\
\hline & & $b$ & 1.97 & 2.68 \\
\hline & & C & 4.08 & 4.3 \\
\hline \multirow[t]{3}{*}{106} & $A$ & $a$ & 1.79 & 0 \\
\hline & & $b$ & 2.33 & 4.3 \\
\hline & & C & 4.39 & 5.5 \\
\hline \multirow[t]{9}{*}{107} & $A$ & $a$ & 1.67 & 1.52 \\
\hline & & $\mathrm{b}$ & 2.17 & 2.13 \\
\hline & & $\mathrm{C}$ & 4.24 & 4.47 \\
\hline & LB & $a$ & 1.47 & 1.8 \\
\hline & & $b$ & 1.96 & 2.03 \\
\hline & & C & \begin{tabular}{ll|}
4.06 \\
\end{tabular} & 3.87 \\
\hline & $\mathrm{RB}$ & $a$ & 1.46 & 1.92 \\
\hline & & $b$ & 2.11 & 2.27 \\
\hline & & $\mathrm{C}$ & 4.35 & 4.43 \\
\hline \multirow[t]{2}{*}{108} & A & $a$ & 1.87 & 0 \\
\hline & & $b$ & 2.49 & 0 \\
\hline
\end{tabular}




\begin{tabular}{|c|c|c|c|c|}
\hline & & C & 4.6 & 4.15 \\
\hline & LB & $a$ & $\begin{array}{l}1.39 \\
\end{array}$ & 1.76 \\
\hline & & $b$ & 2.16 & 2.24 \\
\hline & & $\mathrm{C}$ & 4.09 & 3.64 \\
\hline & $\mathrm{RB}$ & $a$ & 1.8 & 1.82 \\
\hline & & $b$ & 2.46 & 1.72 \\
\hline & & $\mathrm{C}$ & 4.11 & 4.11 \\
\hline \multirow[t]{6}{*}{109} & A & $\mathrm{a}$ & 1.56 & 1.58 \\
\hline & & $b$ & 1.94 & 1.65 \\
\hline & & C & 4.22 & 1.61 \\
\hline & $\mathrm{RB}$ & $a$ & 1.24 & 1.2 \\
\hline & & $b$ & 1.78 & 2.53 \\
\hline & & $\mathrm{C}$ & 3.72 & 3.54 \\
\hline \multirow[t]{9}{*}{110} & A & $a$ & 1.72 & 0.95 \\
\hline & & $b$ & 1.91 & 1.97 \\
\hline & & C & 4.11 & 4.32 \\
\hline & LB & $\mathrm{a}$ & 1.67 & 1.64 \\
\hline & & $b$ & 2.12 & 2.08 \\
\hline & & $\mathrm{C}$ & 4.21 & 4.14 \\
\hline & $\mathrm{RB}$ & $a$ & 1.52 & 1.72 \\
\hline & & $b$ & 1.99 & 2.19 \\
\hline & & $\mathrm{C}$ & 4.08 & 4.14 \\
\hline \multirow[t]{6}{*}{111} & A & $a$ & 1.08 & 1.18 \\
\hline & & $b$ & 2.17 & 2.39 \\
\hline & & $\mathrm{C}$ & 4.56 & 5.06 \\
\hline & LB & $a$ & 1.66 & 1.37 \\
\hline & & b & 2.26 & 2.05 \\
\hline & & $\mathrm{C}$ & 4.39 & 4.25 \\
\hline \multirow[t]{9}{*}{112} & A & $a$ & 1.65 & 1.41 \\
\hline & & $b$ & 1.66 & 1.54 \\
\hline & & $\mathrm{C}$ & 3.83 & 4.13 \\
\hline & LB & $a$ & 1.28 & 1.19 \\
\hline & & $b$ & 1.88 & 1.99 \\
\hline & & $\mathrm{C}$ & 3.83 & 3.65 \\
\hline & $\mathrm{RB}$ & $a$ & 1.71 & 1.58 \\
\hline & & $b$ & 2.16 & 1.96 \\
\hline & & $\mathrm{C}$ & 3.89 & 3.54 \\
\hline \multirow[t]{6}{*}{113} & A & $\mathrm{a}$ & 0 & 0 \\
\hline & & $b$ & 2 & 1.82 \\
\hline & & $\mathrm{C}$ & 3.24 & 3.32 \\
\hline & $\mathrm{RB}$ & $a$ & 1.55 & 1.17 \\
\hline & & $b$ & 2.41 & 2.22 \\
\hline & & C & 4.03 & 3.98 \\
\hline \multirow[t]{4}{*}{114} & LB & $a$ & 1.66 & 1.56 \\
\hline & & $b$ & 1.98 & 2.15 \\
\hline & & $\mathrm{C}$ & 3.84 & 3.98 \\
\hline & $\mathrm{RB}$ & $a$ & 1.71 & 1.74 \\
\hline
\end{tabular}




\begin{tabular}{|c|c|c|c|c|}
\hline & & $b$ & 1.84 & 1.95 \\
\hline & & C & 4.03 & 4.18 \\
\hline \multirow[t]{9}{*}{115} & A & $a$ & 0 & 0 \\
\hline & & $b$ & 1.97 & 0 \\
\hline & & C & 3.98 & 3.75 \\
\hline & LB & $a$ & 2.01 & 1.73 \\
\hline & & $b$ & 2.47 & 2.23 \\
\hline & & C & 4.04 & 4.13 \\
\hline & RB & $a$ & 1.43 & 1.4 \\
\hline & & $b$ & 2.18 & 1.91 \\
\hline & & C & 4.41 & 4.36 \\
\hline \multirow[t]{3}{*}{116} & A & $a$ & 1.48 & 0.99 \\
\hline & & $b$ & 1.9 & 1.58 \\
\hline & & C & 4.06 & 4.67 \\
\hline \multirow[t]{9}{*}{117} & A & $a$ & 0 & 0 \\
\hline & & $b$ & 0 & 1.92 \\
\hline & & C & 3.47 & 0 \\
\hline & LB & $a$ & 1.42 & 1.42 \\
\hline & & $b$ & 2.02 & 1.93 \\
\hline & & C & 4.19 & 4.33 \\
\hline & RB & $a$ & 1.44 & 4.01 \\
\hline & & $b$ & 2.13 & 0 \\
\hline & & $\mathrm{C}$ & 4.09 & 0 \\
\hline \multirow[t]{3}{*}{118} & A & $a$ & 1.47 & 1.28 \\
\hline & & b & 2.01 & 2.15 \\
\hline & & C & 3.76 & 4.28 \\
\hline \multirow[t]{9}{*}{119} & A & $a$ & 1.63 & 1.45 \\
\hline & & b & 2.19 & 2.13 \\
\hline & & $\mathrm{C}$ & 4.29 & 3.9 \\
\hline & LB & $a$ & 1.74 & 1.79 \\
\hline & & $b$ & 2 & 2.07 \\
\hline & & $\mathrm{C}$ & 4.41 & 4.52 \\
\hline & RB & $a$ & 1.99 & 1.58 \\
\hline & & $b$ & 2.11 & 1.55 \\
\hline & & C & 4.3 & 3.45 \\
\hline \multirow[t]{3}{*}{120} & A & $\mathrm{a}$ & 0 & 0.83 \\
\hline & & $b$ & 1.99 & 1.71 \\
\hline & & $\mathrm{C}$ & 3.95 & 3.29 \\
\hline \multirow[t]{6}{*}{121} & $A$ & $a$ & 1.71 & 1.75 \\
\hline & & $b$ & 2.13 & 2.03 \\
\hline & & $\mathrm{C}$ & 4.19 & 3.69 \\
\hline & LB & $a$ & 1.6 & 1.64 \\
\hline & & $b$ & 2.17 & 2.06 \\
\hline & & c & 4.32 & 4.31 \\
\hline \multirow[t]{3}{*}{122} & LB & $a$ & 1.56 & 1.58 \\
\hline & & $b$ & 2.26 & 2.41 \\
\hline & & C & 4.36 & 4.33 \\
\hline
\end{tabular}




\begin{tabular}{|c|c|c|c|c|}
\hline & $\mathrm{RB}$ & $\mathrm{a}$ & 1.79 & 1.39 \\
\hline & & $b$ & 2.32 & 2.09 \\
\hline & & C & 4.52 & 3.76 \\
\hline \multirow[t]{9}{*}{123} & A & $a$ & 1.52 & 1.26 \\
\hline & & $b$ & 1.92 & 2.01 \\
\hline & & C & 4.02 & 4.48 \\
\hline & LB & $a$ & 1.77 & 1.64 \\
\hline & & $b$ & 2.41 & 2.04 \\
\hline & & C & 4.48 & 4.31 \\
\hline & $\mathrm{RB}$ & $a$ & 1.62 & 1.49 \\
\hline & & $b$ & 2.3 & 1.76 \\
\hline & & $\mathrm{C}$ & 3.84 & 4.01 \\
\hline \multirow[t]{3}{*}{124} & A & $a$ & 1.65 & 1.8 \\
\hline & & $b$ & 1.87 & 2 \\
\hline & & $C$ & 4.25 & 3.5 \\
\hline \multirow[t]{6}{*}{125} & A & $a$ & 1.66 & 1.78 \\
\hline & & $b$ & 2.11 & 2.44 \\
\hline & & C & 4.03 & 4.34 \\
\hline & LB & $a$ & 1.7 & 1.83 \\
\hline & & $b$ & 2.09 & 2.02 \\
\hline & & $\mathrm{C}$ & 4.14 & 4.15 \\
\hline \multirow[t]{6}{*}{126} & A & $a$ & 1.59 & 1.32 \\
\hline & & $b$ & 2.32 & 1.85 \\
\hline & & C & 4.63 & 4.33 \\
\hline & $\mathrm{RB}$ & $a$ & 1.72 & 1.4 \\
\hline & & $b$ & 2.1 & 1.9 \\
\hline & & C & 4.89 & 4.45 \\
\hline \multirow[t]{6}{*}{127} & A & $a$ & 1.75 & 1.59 \\
\hline & & $b$ & 2.25 & 2.15 \\
\hline & & C & 4.82 & 4.15 \\
\hline & LB & $a$ & 1.88 & 1.52 \\
\hline & & $b$ & 2.53 & 2.36 \\
\hline & & $\mathrm{C}$ & 3.87 & 3.74 \\
\hline \multirow[t]{6}{*}{128} & A & $a$ & 1.48 & 1.24 \\
\hline & & $b$ & 1.98 & 2.38 \\
\hline & & C & 4.05 & 4.1 \\
\hline & LB & $a$ & 1.45 & 1.8 \\
\hline & & $b$ & 1.92 & 2.1 \\
\hline & & C & 4.51 & 4.25 \\
\hline \multirow[t]{6}{*}{129} & A & $a$ & 1.94 & 1.87 \\
\hline & & $b$ & 2.41 & 2.36 \\
\hline & & $C$ & 4.16 & 4.16 \\
\hline & $\mathrm{RB}$ & $a$ & 1.86 & 1.84 \\
\hline & & $b$ & 2.11 & 2.43 \\
\hline & & $C$ & 4.24 & 4.61 \\
\hline \multirow[t]{2}{*}{130} & A & $a$ & 1.69 & 1.53 \\
\hline & & $b$ & 2.25 & 1.91 \\
\hline
\end{tabular}




\begin{tabular}{|c|c|c|c|c|}
\hline & & C & 4.24 & 4.53 \\
\hline \multirow[t]{3}{*}{131} & $A$ & $a$ & $\begin{array}{l}1.49 \\
\end{array}$ & 1.61 \\
\hline & & $b$ & 1.95 & 1.99 \\
\hline & & $\mathrm{C}$ & 3.87 & 4.11 \\
\hline \multirow[t]{6}{*}{132} & A & $a$ & 1.77 & 1.55 \\
\hline & & $b$ & 2.19 & 2.27 \\
\hline & & $\mathrm{C}$ & 3.62 & 3.49 \\
\hline & $\mathrm{RB}$ & $\mathrm{a}$ & 1.77 & 1.52 \\
\hline & & $b$ & 2.22 & 2.14 \\
\hline & & C & 4.72 & 4.86 \\
\hline \multirow[t]{3}{*}{133} & A & $a$ & 1.6 & 1.81 \\
\hline & & $b$ & 2.35 & 2.09 \\
\hline & & $\mathrm{C}$ & 4.15 & 4.36 \\
\hline \multirow[t]{3}{*}{134} & A & $a$ & 1.39 & 1.63 \\
\hline & & $b$ & 2.15 & 2.02 \\
\hline & & C & 4.27 & 4.42 \\
\hline \multirow[t]{9}{*}{135} & A & $\mathrm{a}$ & 1.65 & 1.88 \\
\hline & & $b$ & 2.12 & 2.27 \\
\hline & & $\mathrm{C}$ & 3.95 & 4.23 \\
\hline & LB & $a$ & 1.58 & 1.83 \\
\hline & & $b$ & 2.21 & 2.48 \\
\hline & & $\mathrm{C}$ & 4.2 & 4.39 \\
\hline & RB & $a$ & 1.79 & 1.59 \\
\hline & & $b$ & 2.11 & 2.35 \\
\hline & & $\mathrm{C}$ & 4.15 & 3.84 \\
\hline \multirow[t]{9}{*}{136} & A & $a$ & 1.66 & 1.58 \\
\hline & & $b$ & 2.05 & 2.04 \\
\hline & & $\mathrm{C}$ & 4.08 & 3.95 \\
\hline & LB & $a$ & 1.86 & 1.61 \\
\hline & & $b$ & 2.31 & 2.14 \\
\hline & & $\mathrm{C}$ & 4.01 & 4.25 \\
\hline & $\mathrm{RB}$ & $a$ & 1.88 & 1.71 \\
\hline & & $b$ & 2.26 & 2.26 \\
\hline & & $\mathrm{C}$ & 3.79 & 4.19 \\
\hline \multirow[t]{3}{*}{137} & A & $a$ & 1.66 & 1.76 \\
\hline & & $b$ & 2.27 & 2.17 \\
\hline & & $\mathrm{C}$ & 4.61 & 4.54 \\
\hline \multirow[t]{3}{*}{138} & A & $a$ & 1.43 & 1.36 \\
\hline & & $b$ & 2.1 & 2.11 \\
\hline & & C & 4.12 & 3.95 \\
\hline \multirow[t]{6}{*}{139} & A & $a$ & 1.94 & 1.74 \\
\hline & & $b$ & 2.36 & 2.2 \\
\hline & & C & 4.12 & 4.15 \\
\hline & RB & $a$ & 1.64 & 1.28 \\
\hline & & $b$ & 2.24 & 2.23 \\
\hline & & $\mathrm{C}$ & 3.85 & 3.98 \\
\hline 140 & A & $a$ & 1.84 & 1.72 \\
\hline
\end{tabular}




\begin{tabular}{|r|r|r|r|r|} 
& & $\mathrm{b}$ & 2.14 & 2.32 \\
\hline & & $\mathrm{c}$ & 4.26 & 4.39 \\
\hline
\end{tabular}

\begin{tabular}{|c|c|c|c|c|}
\hline \multicolumn{5}{|c|}{ Cortical Simulated Defects: 8 impulses 90 degrees } \\
\hline \multirow[b]{2}{*}{ Mandible \# } & \multirow[b]{2}{*}{ Area } & \multirow[b]{2}{*}{ Defect ID } & \multirow{2}{*}{\begin{tabular}{|c|} 
Conventional \\
Diameter
\end{tabular}} & \multirow{2}{*}{$\begin{array}{l}\text { Rendering } \\
\text { Diameter }\end{array}$} \\
\hline & & & & \\
\hline \multirow[t]{9}{*}{101} & $\mathrm{~A}$ & $a$ & 1.12 & 0.97 \\
\hline & & $b$ & 0 & 2.13 \\
\hline & & c & 3.91 & 3.68 \\
\hline & LB & $\mathrm{a}$ & 1.03 & 1.15 \\
\hline & & $b$ & 2.18 & 2.34 \\
\hline & & $\mathrm{C}$ & 4.22 & 4.43 \\
\hline & $\mathrm{RB}$ & $\mathrm{a}$ & 0.91 & 0.95 \\
\hline & & $b$ & 2.1 & 2.1 \\
\hline & & $\mathrm{C}$ & 4.16 & 4.39 \\
\hline \multirow[t]{9}{*}{102} & A & $\mathrm{a}$ & 0.9 & 0.98 \\
\hline & & $b$ & 1.59 & 1.72 \\
\hline & & C & 4.17 & 4.37 \\
\hline & LB & $\mathrm{a}$ & 0.99 & 0.94 \\
\hline & & $b$ & 2 & 2.22 \\
\hline & & $\mathrm{C}$ & 4.05 & 4.45 \\
\hline & $\mathrm{RB}$ & $\mathrm{a}$ & 1.47 & 1.83 \\
\hline & & $b$ & 1.91 & 2.46 \\
\hline & & $\mathrm{c}$ & 3.8 & 4.39 \\
\hline \multirow[t]{9}{*}{103} & A & $a$ & 0 & 3.86 \\
\hline & & $b$ & 1.89 & 1.95 \\
\hline & & c & 3.99 & 1.4 \\
\hline & LB & $\mathrm{a}$ & 1.57 & 1.75 \\
\hline & & $b$ & 2.12 & 2.18 \\
\hline & & $\mathrm{C}$ & 4.06 & 4.16 \\
\hline & $\mathrm{RB}$ & $\mathrm{a}$ & 1.76 & 1.47 \\
\hline & & $b$ & 2.01 & 2.11 \\
\hline & & C & 4.13 & 4.28 \\
\hline \multirow[t]{9}{*}{104} & A & $a$ & 1.64 & 1.32 \\
\hline & & $b$ & 1.91 & 1.97 \\
\hline & & $\mathrm{C}$ & 4.12 & 3.83 \\
\hline & LB & $a$ & 1.52 & 1.52 \\
\hline & & $b$ & 1.94 & 1.97 \\
\hline & & $\mathrm{C}$ & 4.18 & 3.86 \\
\hline & $\mathrm{RB}$ & $a$ & 1.35 & 1.46 \\
\hline & & $b$ & 1.97 & 2.12 \\
\hline & & C & 4.16 & 4.25 \\
\hline \multirow[t]{2}{*}{105} & A & $a$ & 1.43 & 1.63 \\
\hline & & $b$ & 1.82 & 1.51 \\
\hline
\end{tabular}




\begin{tabular}{|c|c|c|c|c|}
\hline & & C & 3.92 & 4.03 \\
\hline & LB & $a$ & 1.46 & 1.59 \\
\hline & & $b$ & 1.97 & 2.14 \\
\hline & & C & 4.08 & 4.25 \\
\hline \multirow[t]{3}{*}{106} & A & $a$ & 1.79 & 0 \\
\hline & & $b$ & 2.33 & 1.79 \\
\hline & & $C$ & 4.39 & 4.4 \\
\hline \multirow[t]{9}{*}{107} & A & $a$ & 1.43 & 1.76 \\
\hline & & $b$ & 1.92 & 1.98 \\
\hline & & 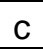 & 3.86 & 3.98 \\
\hline & LB & $a$ & 1.63 & 1.76 \\
\hline & & $b$ & 2.11 & 2.18 \\
\hline & & $C$ & 3.87 & 4.14 \\
\hline & RB & $a$ & 1.57 & 1.66 \\
\hline & & $b$ & 1.78 & 2.33 \\
\hline & & $\mathrm{C}$ & 3.89 & 414 \\
\hline \multirow[t]{9}{*}{108} & A & $a$ & 1.29 & 1.15 \\
\hline & & $b$ & 1.64 & 1.74 \\
\hline & & $\mathrm{C}$ & 3.54 & 3.63 \\
\hline & LB & $a$ & 1.48 & 1.49 \\
\hline & & $b$ & 1.86 & 2.12 \\
\hline & & $C$ & 4.1 & 4.01 \\
\hline & $\mathrm{RB}$ & $a$ & 1.68 & 1.52 \\
\hline & & $\mathrm{b}$ & 1.97 & 2.19 \\
\hline & & $\mathrm{C}$ & 4.1 & 4.22 \\
\hline \multirow[t]{6}{*}{109} & A & $a$ & 1.26 & 2.3 \\
\hline & & $b$ & 1.77 & 1.81 \\
\hline & & $C$ & 4.03 & 4.24 \\
\hline & RB & $a$ & 1.42 & 1.61 \\
\hline & & $b$ & 1.97 & 2.24 \\
\hline & & $\mathrm{C}$ & 3.97 & 4.28 \\
\hline \multirow[t]{9}{*}{110} & A & $a$ & 0.93 & 0.91 \\
\hline & & $b$ & 1.87 & 1.85 \\
\hline & & $\mathrm{C}$ & 3.96 & 3.78 \\
\hline & LB & $a$ & 1.43 & 1.71 \\
\hline & & b & 2.02 & 1.97 \\
\hline & & $\mathrm{C}$ & 4.19 & 4.02 \\
\hline & $\mathrm{RB}$ & $a$ & 1.56 & 1.75 \\
\hline & & $b$ & 2.1 & 2.13 \\
\hline & & $\mathrm{C}$ & 4.18 & 4.35 \\
\hline \multirow[t]{6}{*}{111} & $A$ & $a$ & 1.36 & 1.76 \\
\hline & & $b$ & 2.04 & 1.48 \\
\hline & & C & 4.07 & 4.27 \\
\hline & LB & $a$ & 1.48 & 1.41 \\
\hline & & $b$ & 1.74 & 1.69 \\
\hline & & $\mathrm{C}$ & 3.67 & 3.75 \\
\hline 112 & A & $a$ & 1.49 & 1.22 \\
\hline
\end{tabular}




\begin{tabular}{|c|c|c|c|c|}
\hline & & $b$ & 1.9 & 1.92 \\
\hline & & $\mathrm{C}$ & 4.2 & 3.68 \\
\hline & LB & $a$ & 1.54 & 1.44 \\
\hline & & $b$ & 2.07 & 1.97 \\
\hline & & $\mathrm{C}$ & 3.98 & 3.55 \\
\hline & $\mathrm{RB}$ & $a$ & 1.5 & 1.36 \\
\hline & & $b$ & 2.03 & 1.89 \\
\hline & & $c$ & 4.1 & 3.79 \\
\hline \multirow[t]{6}{*}{113} & $A$ & $a$ & 1.39 & 1.25 \\
\hline & & $b$ & 1.85 & 1.77 \\
\hline & & $C$ & 4.06 & 3.52 \\
\hline & RB & $a$ & 1.62 & 1.65 \\
\hline & & $b$ & 1.97 & 1.81 \\
\hline & & $\mathrm{C}$ & 4.17 & 3.82 \\
\hline \multirow[t]{6}{*}{114} & LB & $a$ & 6.5 & 1.74 \\
\hline & & $\mathrm{b}$ & 5.86 & 2.06 \\
\hline & & $\mathrm{C}$ & 5.32 & 4.25 \\
\hline & RB & $a$ & 1.6 & 1.61 \\
\hline & & $b$ & 1.62 & 1.63 \\
\hline & & $C$ & 4.22 & 4.13 \\
\hline \multirow[t]{9}{*}{115} & A & $a$ & 1.32 & 0 \\
\hline & & $b$ & 1.91 & 0 \\
\hline & & $\mathrm{C}$ & 3.63 & 3.15 \\
\hline & LB & $a$ & 1.49 & 1.6 \\
\hline & & $b$ & 1.91 & 2.06 \\
\hline & & C & 3.99 & 4.18 \\
\hline & RB & $a$ & 1.53 & 1.54 \\
\hline & & $b$ & 2.01 & 2.18 \\
\hline & & $\mathrm{C}$ & 4.16 & 3.96 \\
\hline \multirow[t]{3}{*}{116} & A & $a$ & 1.3 & 1.5 \\
\hline & & $b$ & 1.79 & 0 \\
\hline & & $\mathrm{C}$ & 4.17 & 4.24 \\
\hline \multirow[t]{9}{*}{117} & A & $a$ & 0 & 1.31 \\
\hline & & $b$ & 2.24 & 1.63 \\
\hline & & C & 3.56 & 4.09 \\
\hline & LB & $a$ & 1.42 & 1.5 \\
\hline & & $b$ & 2.02 & 2.17 \\
\hline & & $\mathrm{C}$ & 3.91 & 3.98 \\
\hline & $\mathrm{RB}$ & $a$ & 1.32 & 4.41 \\
\hline & & $b$ & 1.95 & 1.36 \\
\hline & & $C$ & 4.13 & 0 \\
\hline \multirow[t]{3}{*}{118} & $A$ & $a$ & 1.6 & 1.08 \\
\hline & & $b$ & 1.9 & 2.04 \\
\hline & & C & 4.04 & 4.05 \\
\hline \multirow[t]{3}{*}{119} & A & $a$ & 1.37 & 1.17 \\
\hline & & $b$ & 2.07 & 1.93 \\
\hline & & C & 3.71 & 3.89 \\
\hline
\end{tabular}




\begin{tabular}{|c|c|c|c|c|}
\hline & LB & $\mathrm{a}$ & 1.46 & 1.39 \\
\hline & & $b$ & 1.99 & 1.98 \\
\hline & & $C$ & 4.28 & 3.93 \\
\hline & RB & $a$ & 1.55 & 1.53 \\
\hline & & $b$ & 2.05 & 1 \\
\hline & & $\mathrm{C}$ & 4.25 & 4.07 \\
\hline \multirow[t]{3}{*}{120} & A & $a$ & 0 & 1.2 \\
\hline & & $b$ & 1.96 & 2.33 \\
\hline & & $C$ & 3.5 & 3.1 \\
\hline \multirow[t]{6}{*}{121} & $A$ & $a$ & 1.59 & \\
\hline & & $b$ & 2.17 & \\
\hline & & $C$ & 4.22 & \\
\hline & LB & $a$ & 1.51 & 1.57 \\
\hline & & $b$ & 2.15 & 2.17 \\
\hline & & $\mathrm{C}$ & 4.08 & 4.07 \\
\hline \multirow[t]{6}{*}{122} & LB & $a$ & 1.58 & 1.89 \\
\hline & & $b$ & 2.12 & 2.23 \\
\hline & & C & 4.27 & 4.39 \\
\hline & $\mathrm{RB}$ & $a$ & 1.54 & 1.66 \\
\hline & & $\mathrm{b}$ & 2.12 & 2.22 \\
\hline & & $\mathrm{C}$ & 4.07 & 4.3 \\
\hline \multirow[t]{9}{*}{123} & $A$ & $a$ & 1.61 & 1.65 \\
\hline & & $b$ & 1.95 & 2.06 \\
\hline & & C & 3.96 & 4.47 \\
\hline & LB & $a$ & 1.51 & 1.63 \\
\hline & & $b$ & 2.06 & 2.02 \\
\hline & & C & 4.18 & 4.06 \\
\hline & RB & $a$ & 1.43 & 1.51 \\
\hline & & $b$ & 1.92 & 1.97 \\
\hline & & $C$ & 4.13 & 4.1 \\
\hline \multirow[t]{3}{*}{124} & A & $a$ & 1.66 & 1.66 \\
\hline & & $b$ & 2.02 & 2.14 \\
\hline & & $C$ & 4.44 & 3.96 \\
\hline \multirow[t]{6}{*}{125} & $A$ & $a$ & 1.63 & 1.55 \\
\hline & & $b$ & 2.15 & 2.25 \\
\hline & & C & 4 & 4.23 \\
\hline & LB & $a$ & 1.74 & 1.6 \\
\hline & & $b$ & 1.92 & 2.11 \\
\hline & & $\mathrm{C}$ & 4.16 & 4.25 \\
\hline \multirow[t]{6}{*}{126} & $A$ & $a$ & 1.74 & 1.23 \\
\hline & & $b$ & 2.15 & 1.99 \\
\hline & & C & 3.85 & 3.86 \\
\hline & $\mathrm{RB}$ & $a$ & 1.55 & 1.53 \\
\hline & & $b$ & 2.32 & 2.18 \\
\hline & & $\mathrm{C}$ & 4.33 & 4.81 \\
\hline \multirow[t]{2}{*}{127} & A & $a$ & 1.5 & 1.62 \\
\hline & & $b$ & 1.94 & 2.11 \\
\hline
\end{tabular}




\begin{tabular}{|c|c|c|c|c|}
\hline & & C & 4.2 & 4.25 \\
\hline & LB & $a$ & 1.47 & 1.72 \\
\hline & & $b$ & 2.12 & 2.19 \\
\hline & & C & 3.92 & 4.02 \\
\hline \multirow[t]{6}{*}{128} & A & $a$ & 1.46 & 1.16 \\
\hline & & $b$ & 2.11 & 1.95 \\
\hline & & $C$ & 4.17 & 4.07 \\
\hline & LB & $a$ & 1.85 & 1.66 \\
\hline & & $b$ & 2.22 & 2.51 \\
\hline & & 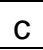 & 4.23 & 4.21 \\
\hline \multirow[t]{6}{*}{129} & A & $a$ & 1.57 & 1.46 \\
\hline & & $b$ & 2.03 & 2.15 \\
\hline & & $\mathrm{C}$ & 4.11 & 4.03 \\
\hline & RB & $a$ & 1.63 & 1.76 \\
\hline & & $b$ & 2.28 & 2.26 \\
\hline & & $\mathrm{C}$ & 4.09 & 4.37 \\
\hline \multirow[t]{3}{*}{130} & A & $a$ & 1.64 & 1.86 \\
\hline & & $b$ & 2.14 & 2.14 \\
\hline & & c & 3.69 & 4.21 \\
\hline \multirow[t]{3}{*}{131} & A & $a$ & 1.73 & 1.6 \\
\hline & & $b$ & 2.12 & 2.18 \\
\hline & & $C$ & 4.03 & 4.13 \\
\hline \multirow[t]{6}{*}{132} & A & $a$ & 1.52 & 1.5 \\
\hline & & $\mathrm{b}$ & 2.32 & 1.89 \\
\hline & & $\mathrm{C}$ & 4.15 & 3.97 \\
\hline & RB & $a$ & 1.72 & 1.62 \\
\hline & & $b$ & 2.14 & 2.05 \\
\hline & & $C$ & 4.72 & 4.89 \\
\hline \multirow[t]{3}{*}{133} & A & $a$ & 1.53 & 1.78 \\
\hline & & $b$ & 2.08 & 2.08 \\
\hline & & $\mathrm{C}$ & 4.45 & 4.25 \\
\hline \multirow[t]{3}{*}{134} & A & $a$ & 1.59 & 1.64 \\
\hline & & $b$ & 2 & 2.18 \\
\hline & & $\mathrm{C}$ & 3.51 & 3.98 \\
\hline \multirow[t]{9}{*}{135} & A & $a$ & 1.5 & 1.61 \\
\hline & & $b$ & 2.07 & 2.22 \\
\hline & & C & 3.96 & 4.18 \\
\hline & LB & $a$ & 1.59 & 1.73 \\
\hline & & $b$ & 2.04 & 2.23 \\
\hline & & $\mathrm{C}$ & 4.18 & 4.31 \\
\hline & $\mathrm{RB}$ & $a$ & 1.49 & 4.54 \\
\hline & & $b$ & 2.1 & 2.16 \\
\hline & & C & 4.11 & 4.27 \\
\hline \multirow[t]{4}{*}{136} & A & $a$ & 1.63 & 1.51 \\
\hline & & $b$ & 1.9 & 2.05 \\
\hline & & $\mathrm{C}$ & 4.01 & 4.22 \\
\hline & LB & $a$ & 1.68 & 1.72 \\
\hline
\end{tabular}




\begin{tabular}{|c|c|c|c|c|}
\hline & & $\mathrm{b}$ & 2.07 & 1.99 \\
\hline & & C & 3.97 & 3.89 \\
\hline & RB & $a$ & 1.69 & 1.64 \\
\hline & & b & 1.96 & 2.31 \\
\hline & & C & 3.98 & 4.38 \\
\hline \multirow[t]{3}{*}{137} & A & $\mathrm{a}$ & 1.57 & 1.53 \\
\hline & & $b$ & 1.87 & 2.12 \\
\hline & & C & 4.34 & 4.07 \\
\hline \multirow[t]{3}{*}{138} & A & a & 1.45 & 1.61 \\
\hline & & $b$ & 2.1 & 2.15 \\
\hline & & C & 4.15 & 4.17 \\
\hline \multirow[t]{6}{*}{139} & A & a & 1.55 & 1.57 \\
\hline & & b & 2 & 2.09 \\
\hline & & $\mathrm{C}$ & 4.08 & 4.24 \\
\hline & RB & $a$ & 1.49 & 1.52 \\
\hline & & $\mathrm{b}$ & 2.05 & 2.24 \\
\hline & & C & 4.24 & 4.27 \\
\hline \multirow[t]{3}{*}{140} & A & $a$ & 1.72 & 1.86 \\
\hline & & b & 2.02 & 2.34 \\
\hline & & c & 4.16 & 4.24 \\
\hline
\end{tabular}

Cortical Simulated Defects: 18 impulses 90 degrees

\begin{tabular}{|c|c|c|c|c|}
\hline \multirow[b]{2}{*}{ Mandible \# } & \multirow[b]{2}{*}{ Area } & \multirow[b]{2}{*}{ Defect ID } & Conventional & Rendering \\
\hline & & & Diameter & Diameter \\
\hline \multirow[t]{9}{*}{101} & $A$ & $\mathrm{a}$ & 1.09 & 1.51 \\
\hline & & b & 0 & 2.1 \\
\hline & & C & 3.78 & 4.49 \\
\hline & LB & $a$ & 1.1 & 0.96 \\
\hline & & $b$ & 2.15 & 2.48 \\
\hline & & $\mathrm{C}$ & 4.21 & 4.4 \\
\hline & RB & a & 1 & 1.12 \\
\hline & & b & 2.16 & 2.22 \\
\hline & & $\mathrm{C}$ & 4.15 & 4.56 \\
\hline \multirow[t]{9}{*}{102} & A & a & 1.05 & 1.23 \\
\hline & & b & 1.63 & 1.77 \\
\hline & & $\mathrm{C}$ & 4 & 4.33 \\
\hline & LB & $\mathrm{a}$ & 0.86 & 0.88 \\
\hline & & $b$ & 2.14 & 2.17 \\
\hline & & C & 4.21 & 4.46 \\
\hline & RB & a & 1.65 & 1.93 \\
\hline & & b & 2.19 & 2.2 \\
\hline & & C & 4.07 & 4.38 \\
\hline 103 & A & a & 4.15 & 1.4 \\
\hline
\end{tabular}




\begin{tabular}{|c|c|c|c|c|}
\hline & & $b$ & 1.62 & 1.61 \\
\hline & & $C$ & 0 & 4.1 \\
\hline & LB & a & 1.72 & 1.56 \\
\hline & & $b$ & 1.98 & 2.43 \\
\hline & & $C$ & 3.78 & 4 \\
\hline & RB & a & 1.47 & 1.8 \\
\hline & & $b$ & 1.78 & 2.1 \\
\hline & & C & 4 & 4.35 \\
\hline \multirow[t]{9}{*}{104} & A & $a$ & 1.53 & 1.45 \\
\hline & & $b$ & 2.09 & 2.11 \\
\hline & & $C$ & 1.43 & 3.95 \\
\hline & LB & a & 1.52 & 1.77 \\
\hline & & $b$ & 2.1 & 2.26 \\
\hline & & C & 3.85 & 4.14 \\
\hline & RB & $\mathrm{a}$ & 1.45 & 1.56 \\
\hline & & $b$ & 1.91 & 2.09 \\
\hline & & $\mathrm{C}$ & 4.11 & 4.07 \\
\hline \multirow[t]{6}{*}{105} & A & $a$ & 1.45 & 1.77 \\
\hline & & $b$ & 1.93 & 1.18 \\
\hline & & C & 3.87 & 4.12 \\
\hline & LB & $\mathrm{a}$ & 1.48 & 1.58 \\
\hline & & $b$ & 2.07 & 2.15 \\
\hline & & $\mathrm{C}$ & 4.05 & 3.93 \\
\hline \multirow[t]{3}{*}{106} & A & a & 1.56 & 0 \\
\hline & & $b$ & 2.01 & 1.82 \\
\hline & & $C$ & 4 & 4.4 \\
\hline \multirow[t]{9}{*}{107} & A & a & 1.32 & 1.63 \\
\hline & & $\mathrm{b}$ & 1.92 & 1.88 \\
\hline & & C & 3.7 & 3.8 \\
\hline & LB & $a$ & 1.48 & 1.87 \\
\hline & & $b$ & 2.05 & 2.22 \\
\hline & & $C$ & 4.06 & 4.11 \\
\hline & $\mathrm{RB}$ & $a$ & 1.5 & 1.85 \\
\hline & & $b$ & 1.93 & 2.62 \\
\hline & & $C$ & 4 & 4.47 \\
\hline \multirow[t]{9}{*}{108} & A & $a$ & 1.62 & 1.11 \\
\hline & & $b$ & 2.01 & 1.82 \\
\hline & & $\mathrm{C}$ & 3.91 & 3.62 \\
\hline & LB & $a$ & 1.49 & 1.56 \\
\hline & & $b$ & 2 & 2.05 \\
\hline & & C & 4.1 & 4.08 \\
\hline & RB & a & 1.41 & 1.74 \\
\hline & & $b$ & 1.91 & 2.19 \\
\hline & & C & 3.87 & 4.19 \\
\hline \multirow[t]{3}{*}{109} & A & $a$ & 1.79 & 1.65 \\
\hline & & $b$ & 1.18 & 2.31 \\
\hline & & C & 4.08 & 4.3 \\
\hline
\end{tabular}




\begin{tabular}{|c|c|c|c|c|}
\hline & RB & a & 1.43 & 1.7 \\
\hline & & $b$ & 2.1 & 2.38 \\
\hline & & C & 3.97 & 4.27 \\
\hline \multirow[t]{9}{*}{110} & A & $a$ & 1.33 & 1.19 \\
\hline & & $b$ & 1.88 & 1.8 \\
\hline & & C & 4.13 & 3.8 \\
\hline & LB & $a$ & 1.52 & 1.64 \\
\hline & & b & 2.13 & 2.12 \\
\hline & & C & 4.2 & 4.13 \\
\hline & RB & $a$ & 1.47 & 1.64 \\
\hline & & $b$ & 2.04 & 2.21 \\
\hline & & C & 4.1 & 4.09 \\
\hline \multirow[t]{6}{*}{111} & A & $a$ & 1.42 & 1.79 \\
\hline & & $b$ & 2.04 & 1.72 \\
\hline & & $C$ & 4.12 & 4.57 \\
\hline & LB & a & 1.6 & 1.62 \\
\hline & & $b$ & 1.61 & 1.45 \\
\hline & & C & 3.93 & 3.83 \\
\hline \multirow[t]{9}{*}{112} & A & $a$ & 1.37 & 1.18 \\
\hline & & b & 1.72 & 1.86 \\
\hline & & $\mathrm{C}$ & 3.97 & 3.69 \\
\hline & LB & $a$ & 1.47 & 1.41 \\
\hline & & $b$ & 1.92 & 1.75 \\
\hline & & C & 3.95 & 3.58 \\
\hline & RB & $\mathrm{a}$ & 1.63 & 1.45 \\
\hline & & $b$ & 2.04 & 1.92 \\
\hline & & C & 4.07 & 3.73 \\
\hline \multirow[t]{6}{*}{113} & A & a & 1.19 & 1.11 \\
\hline & & $b$ & 1.87 & 1.78 \\
\hline & & $C$ & 3.77 & 3.49 \\
\hline & RB & $\mathrm{a}$ & 1.76 & 1.7 \\
\hline & & $b$ & 2.07 & 1.98 \\
\hline & & $C$ & 4.18 & 3.79 \\
\hline \multirow[t]{6}{*}{114} & LB & $a$ & 1.6 & 1.68 \\
\hline & & $b$ & 2.05 & 2.22 \\
\hline & & C & 4.16 & 4.23 \\
\hline & $\mathrm{RB}$ & $a$ & 1.6 & 1.52 \\
\hline & & $b$ & 1.61 & 1.62 \\
\hline & & C & 4.15 & 3.95 \\
\hline \multirow[t]{8}{*}{115} & A & $a$ & 1.35 & 0 \\
\hline & & $b$ & 1.94 & 0 \\
\hline & & C & 3.48 & 3.44 \\
\hline & LB & a & 1.33 & 1.65 \\
\hline & & $b$ & 1.95 & 2.03 \\
\hline & & C & 3.98 & 4.18 \\
\hline & RB & a & 1.47 & 1.61 \\
\hline & & b & 2.03 & 2.16 \\
\hline
\end{tabular}




\begin{tabular}{|c|c|c|c|c|}
\hline & & C & 3.95 & 4.34 \\
\hline \multirow[t]{3}{*}{116} & A & $a$ & 1.41 & 1.58 \\
\hline & & $b$ & 2.21 & 0 \\
\hline & & C & 4.12 & 4.09 \\
\hline \multirow[t]{9}{*}{117} & A & $a$ & 0 & 1.64 \\
\hline & & $b$ & 1.84 & 1.8 \\
\hline & & C & 3.86 & 4.05 \\
\hline & LB & a & 1.25 & 1.16 \\
\hline & & $b$ & 1.97 & 2.09 \\
\hline & & C & 3.96 & 3.77 \\
\hline & $\mathrm{RB}$ & $a$ & 1.7 & 4.2 \\
\hline & & $b$ & 2.21 & 1.98 \\
\hline & & $C$ & 4.19 & 0 \\
\hline \multirow[t]{3}{*}{118} & A & $a$ & 1.56 & 1.26 \\
\hline & & $b$ & 1.88 & 2.04 \\
\hline & & $\mathrm{C}$ & 4.08 & 4.04 \\
\hline \multirow[t]{9}{*}{119} & A & $a$ & 1.47 & 1.43 \\
\hline & & $b$ & 2 & 1.91 \\
\hline & & C & 3.8 & 3.72 \\
\hline & LB & $a$ & 1.47 & 1.27 \\
\hline & & $b$ & 1.98 & 1.97 \\
\hline & & C & 4.08 & 4.06 \\
\hline & RB & $\mathrm{a}$ & 1.26 & 1.2 \\
\hline & & $b$ & 2.1 & 1.88 \\
\hline & & C & 4.11 & 3.9 \\
\hline \multirow[t]{3}{*}{120} & A & $a$ & 1.26 & 1.2 \\
\hline & & $b$ & 1.87 & 1.69 \\
\hline & & $C$ & 3.78 & 2.9 \\
\hline \multirow[t]{6}{*}{121} & A & $a$ & 1.57 & 1.59 \\
\hline & & $b$ & 2.21 & 2.08 \\
\hline & & C & 4.31 & 4.1 \\
\hline & LB & $a$ & 1.45 & 1.64 \\
\hline & & $b$ & 2.06 & 2.14 \\
\hline & & C & 3.97 & 4.26 \\
\hline \multirow[t]{6}{*}{122} & LB & $a$ & 1.66 & 1.72 \\
\hline & & $b$ & 2.16 & 2.22 \\
\hline & & C & 4.31 & 4.38 \\
\hline & $\mathrm{RB}$ & $a$ & 1.64 & 1.63 \\
\hline & & $b$ & 2.11 & 2.12 \\
\hline & & C & 4.21 & 4.21 \\
\hline \multirow[t]{7}{*}{123} & A & $a$ & 1.59 & 1.63 \\
\hline & & $b$ & 1.98 & 2.24 \\
\hline & & $C$ & 4.13 & 4.67 \\
\hline & LB & $a$ & 1.39 & 1.61 \\
\hline & & $b$ & 1.88 & 2.18 \\
\hline & & C & 4.05 & 4.01 \\
\hline & RB & a & 1.69 & 1.51 \\
\hline
\end{tabular}




\begin{tabular}{|c|c|c|c|c|}
\hline & & $b$ & 2.09 & 2.18 \\
\hline & & $C$ & 3.89 & 4.16 \\
\hline \multirow[t]{3}{*}{124} & A & $a$ & 1.75 & 1.65 \\
\hline & & b & 2.1 & 2.11 \\
\hline & & $\mathrm{C}$ & 4.07 & 3.81 \\
\hline \multirow[t]{6}{*}{125} & A & $a$ & 1.51 & 1.6 \\
\hline & & $b$ & 1.84 & 2.26 \\
\hline & & C & 4.03 & 4.14 \\
\hline & LB & $a$ & 1.67 & 1.8 \\
\hline & & $b$ & 2.05 & 2.24 \\
\hline & & C & 4.14 & 4.47 \\
\hline \multirow[t]{6}{*}{126} & A & a & 1.56 & 1.25 \\
\hline & & $b$ & 2.3 & 2.23 \\
\hline & & $\mathrm{C}$ & 4.22 & 3.96 \\
\hline & $\mathrm{RB}$ & $a$ & 1.5 & 1.38 \\
\hline & & $b$ & 2.06 & 2.52 \\
\hline & & $\mathrm{C}$ & 4.36 & 5.5 \\
\hline \multirow[t]{6}{*}{127} & A & $a$ & 1.44 & 1.52 \\
\hline & & $b$ & 1.79 & 1.89 \\
\hline & & C & 4.23 & 4.18 \\
\hline & LB & a & 1.57 & 1.53 \\
\hline & & $b$ & 2.15 & 2.2 \\
\hline & & $\mathrm{C}$ & 3.96 & 3.86 \\
\hline \multirow[t]{6}{*}{128} & A & $a$ & 1.6 & 1.49 \\
\hline & & $b$ & 2.04 & 2.17 \\
\hline & & C & 4.2 & 4.33 \\
\hline & LB & a & 1.72 & 1.51 \\
\hline & & b & 2.17 & 2.15 \\
\hline & & C & 4.23 & 4.25 \\
\hline \multirow[t]{6}{*}{129} & A & $a$ & 1.64 & 1.49 \\
\hline & & b & 2.14 & 2.09 \\
\hline & & C & 4.27 & 4.01 \\
\hline & RB & $a$ & 1.61 & 1.63 \\
\hline & & $b$ & 2.21 & 2.12 \\
\hline & & $\mathrm{C}$ & 4.22 & 4.13 \\
\hline \multirow[t]{3}{*}{130} & A & a & 1.58 & 1.68 \\
\hline & & $b$ & 2.11 & 2.42 \\
\hline & & $\mathrm{C}$ & 3.7 & 3.93 \\
\hline \multirow[t]{3}{*}{131} & A & a & 1.69 & 1.71 \\
\hline & & $b$ & 2.12 & 2.27 \\
\hline & & C & 4.01 & 4.25 \\
\hline \multirow[t]{6}{*}{132} & A & a & 1.61 & 1.6 \\
\hline & & $b$ & 2.44 & 2.15 \\
\hline & & C & 3.9 & 3.93 \\
\hline & $\mathrm{RB}$ & $a$ & 1.6 & 1.77 \\
\hline & & $b$ & 1.97 & 2.24 \\
\hline & & C & 4.75 & 4.74 \\
\hline
\end{tabular}




\begin{tabular}{|c|c|c|c|c|}
\hline 133 & A & a & 1.63 & 1.6 \\
\hline & & $b$ & 2.26 & 2.11 \\
\hline & & C & 4.41 & 4.33 \\
\hline \multirow[t]{3}{*}{134} & A & $a$ & 1.75 & 1.65 \\
\hline & & $b$ & 2.12 & 2.09 \\
\hline & & $\mathrm{C}$ & 3.56 & 3.65 \\
\hline \multirow[t]{9}{*}{135} & A & $a$ & 1.52 & 1.51 \\
\hline & & $b$ & 2.09 & 2.17 \\
\hline & & C & 4.02 & 4.14 \\
\hline & LB & $a$ & 1.55 & 1.82 \\
\hline & & $b$ & 2.12 & 2.21 \\
\hline & & C & 4.21 & 4.25 \\
\hline & RB & a & 1.5 & 4.54 \\
\hline & & $b$ & 2.09 & 2.06 \\
\hline & & C & 4.02 & 3.91 \\
\hline \multirow[t]{9}{*}{136} & A & $a$ & 1.72 & 1.64 \\
\hline & & b & 1.9 & 2.03 \\
\hline & & $C$ & 3.95 & 4.11 \\
\hline & LB & $a$ & 1.54 & 1.57 \\
\hline & & b & 1.98 & 2.12 \\
\hline & & C & 3.77 & 4.13 \\
\hline & RB & a & 1.61 & 1.9 \\
\hline & & $b$ & 2 & 2.31 \\
\hline & & $\mathrm{C}$ & 3.97 & 4.25 \\
\hline \multirow[t]{3}{*}{137} & A & a & 1.5 & 1.59 \\
\hline & & $b$ & 2.09 & 2.25 \\
\hline & & C & 4.16 & 4.03 \\
\hline \multirow[t]{3}{*}{138} & A & $a$ & 1.62 & 1.5 \\
\hline & & $b$ & 2.11 & 2.16 \\
\hline & & $\mathrm{C}$ & 4.01 & 4.08 \\
\hline \multirow[t]{6}{*}{139} & A & $a$ & 1.35 & 1.44 \\
\hline & & $b$ & 1.97 & 1.97 \\
\hline & & C & 4 & 4.09 \\
\hline & RB & $a$ & 1.53 & 1.51 \\
\hline & & $b$ & 2.02 & 2.18 \\
\hline & & C & 4.2 & 4.02 \\
\hline \multirow[t]{3}{*}{140} & A & a & 1.69 & 1.79 \\
\hline & & $b$ & 2.02 & 2.29 \\
\hline & & C & 4.18 & 4.11 \\
\hline
\end{tabular}




\begin{tabular}{|c|c|c|c|c|c|c|}
\hline \multicolumn{7}{|c|}{ Intracortical Simulated Defects : 12 impulses 90 degrees } \\
\hline \multirow[b]{2}{*}{ Mandible \# } & \multirow[b]{2}{*}{ Area } & \multirow[b]{2}{*}{ Defect ID } & \multicolumn{2}{|c|}{ Conventional Films } & \multicolumn{2}{|c|}{ Renderings } \\
\hline & & & width & length & width & length \\
\hline \multirow[t]{9}{*}{101} & $A$ & $a$ & 0.94 & 5.94 & 0.77 & 4.26 \\
\hline & & $\mathrm{b}$ & 2.08 & 6.45 & 2.32 & 6.19 \\
\hline & & $\mathrm{c}$ & 4 & 6.07 & 4.06 & 5.61 \\
\hline & LB & $a$ & 0.93 & 5.41 & 0 & 0 \\
\hline & & $\mathrm{b}$ & 1.69 & 6.08 & 2.02 & 3.85 \\
\hline & & $\mathrm{c}$ & 3.84 & 6.1 & 3.55 & 3.93 \\
\hline & $\mathrm{RB}$ & $\mathrm{a}$ & 0.96 & 4.71 & 0 & 0 \\
\hline & & $\mathrm{b}$ & 2.03 & 5.29 & 0 & 0 \\
\hline & & c & 3.66 & 5.98 & 4.22 & 6.4 \\
\hline \multirow[t]{9}{*}{102} & A & $\mathrm{a}$ & 0 & 0 & 0 & 0 \\
\hline & & $\mathrm{b}$ & 0 & 0 & 3.65 & 6.15 \\
\hline & & c & 3.77 & 5.95 & 0 & 0 \\
\hline & LB & $\mathrm{a}$ & 0 & 0 & 0 & 0 \\
\hline & & $\mathrm{b}$ & 0 & 0 & 0 & 0 \\
\hline & & $\mathrm{C}$ & 3.79 & 6.25 & 3.34 & 5.04 \\
\hline & $\mathrm{RB}$ & $a$ & 0 & 0 & 0 & 0 \\
\hline & & $\mathrm{b}$ & 0 & 0 & 0 & 0 \\
\hline & & $\mathrm{C}$ & 0 & 0 & 0 & 0 \\
\hline \multirow[t]{9}{*}{103} & $A$ & $a$ & 1.31 & 5.58 & 1.05 & 3.64 \\
\hline & & $b$ & 2.81 & 6.34 & 2.23 & 4.65 \\
\hline & & $\mathrm{C}$ & 4 & 7.3 & 4.07 & 5.55 \\
\hline & LB & $a$ & 0 & 0 & 0 & 0 \\
\hline & & $b$ & 0 & 0 & 2.59 & 4.98 \\
\hline & & C & 0 & 0 & 0 & 0 \\
\hline & $\mathrm{RB}$ & $a$ & 0.93 & 5.72 & 0 & 0 \\
\hline & & $b$ & 2.44 & 6.13 & 0 & 0 \\
\hline & & C & 3.57 & 0 & 3.71 & 5.48 \\
\hline \multirow[t]{9}{*}{104} & $A$ & $a$ & 1.2 & 6.58 & 2.01 & 6.45 \\
\hline & & $b$ & 1.85 & 5.67 & 0.95 & 4.63 \\
\hline & & $\mathrm{c}$ & 3.74 & 6.53 & 3.71 & 6.02 \\
\hline & LB & $a$ & 1.33 & 0 & 1.22 & 5.58 \\
\hline & & $b$ & 1.9 & 6.59 & 2 & 6.41 \\
\hline & & $\mathrm{c}$ & 4.08 & 6.84 & 3.91 & 7.21 \\
\hline & $\mathrm{RB}$ & $a$ & 1.49 & 6.09 & 1.09 & 4.82 \\
\hline & & $b$ & 2.06 & 6.85 & 0 & 0 \\
\hline & & c & 4.21 & 6.21 & 4.03 & 5.98 \\
\hline \multirow[t]{6}{*}{105} & A & $\mathrm{a}$ & 1.36 & 0 & 1.42 & 5.16 \\
\hline & & $b$ & 1.57 & 5.29 & 1.78 & 5.42 \\
\hline & & C & 3.9 & 6.34 & 4.18 & 6.53 \\
\hline & LB & $a$ & 0 & 0 & 0 & 0 \\
\hline & & $b$ & 2.12 & 0 & 0 & 0 \\
\hline & & C & 4.15 & 6.16 & 3.86 & 6.38 \\
\hline 106 & $A$ & $a$ & 1.69 & 6.85 & 2.38 & 7.72 \\
\hline
\end{tabular}




\begin{tabular}{|c|c|c|c|c|c|c|}
\hline & & $\mathrm{b}$ & 1.23 & 5.32 & 1.86 & 6.8 \\
\hline & & $\mathrm{C}$ & 3.9 & 6.83 & 4.61 & 8.47 \\
\hline \multirow[t]{9}{*}{107} & A & $a$ & 1.45 & 6.22 & 1.3 & 5.85 \\
\hline & & $b$ & 2.45 & 5.59 & 2.21 & 5.39 \\
\hline & & $\mathrm{C}$ & 4.33 & 5.9 & 3.83 & 5.92 \\
\hline & LB & $a$ & 1.53 & 0 & 1.41 & 0 \\
\hline & & $b$ & 2.2 & 5.42 & 1.82 & 0 \\
\hline & & $\mathrm{C}$ & 4.29 & 6.8 & 4.4 & 0 \\
\hline & RB & $a$ & 2.16 & 6.89 & 1.55 & 6.37 \\
\hline & & $b$ & 1.47 & 6.47 & 1.42 & 5.84 \\
\hline & & C & 3.8 & 6.81 & 3.87 & 7.04 \\
\hline \multirow[t]{9}{*}{108} & A & a & 1.29 & 4.25 & 1.43 & 4.11 \\
\hline & & $b$ & 1.69 & 5.52 & 1.64 & 5.22 \\
\hline & & $\mathrm{C}$ & 3.8 & 4.84 & 3.4 & 4.86 \\
\hline & LB & $a$ & 0.91 & 5.74 & 1.58 & 3.88 \\
\hline & & $b$ & 1.76 & 5.42 & 3.22 & 5.52 \\
\hline & & $\mathrm{C}$ & 3.79 & 5.82 & 0 & 0 \\
\hline & RB & $a$ & 1.39 & 0 & 1.12 & 2.95 \\
\hline & & $b$ & 1.39 & 0 & 1.5 & $1 . .59$ \\
\hline & & C & 3.97 & 0 & 3.71 & 4.7 \\
\hline \multirow[t]{6}{*}{109} & A & $a$ & 1.4 & 0 & 1.81 & 5 \\
\hline & & $b$ & 2.44 & 0 & 2.64 & 6.85 \\
\hline & & $\mathrm{C}$ & 4.05 & 0 & 3.92 & 6.65 \\
\hline & RB & a & 0 & 0 & 1.27 & 0 \\
\hline & & $b$ & 0 & 0 & 2.03 & 0 \\
\hline & & C & 0 & 0 & 3.31 & 7.65 \\
\hline \multirow[t]{9}{*}{110} & A & a & 0 & 0 & 0 & 0 \\
\hline & & $b$ & 0 & 0 & 0 & 0 \\
\hline & & $\mathrm{C}$ & 4.17 & 6.03 & 3.86 & 5.23 \\
\hline & LB & $a$ & 1.6 & 0 & 0 & 0 \\
\hline & & $b$ & 0 & 0 & 2.47 & 0 \\
\hline & & C & 3.47 & 0 & 4.06 & 0 \\
\hline & RB & a & 1.29 & 5.54 & 0 & 0 \\
\hline & & $b$ & 1.78 & 0 & 2.11 & 0 \\
\hline & & C & 3.87 & 5.85 & 3.5 & 0 \\
\hline \multirow[t]{6}{*}{111} & A & $\mathrm{a}$ & 1.63 & 6.77 & 1.81 & 6.81 \\
\hline & & $b$ & 2.48 & 0 & 2.81 & 0 \\
\hline & & C & 3.9 & 6.39 & 4.19 & 6.89 \\
\hline & LB & $a$ & 1.43 & 5.54 & 0 & 0 \\
\hline & & $b$ & 2.66 & 6.02 & 0 & 0 \\
\hline & & $\mathrm{C}$ & 3.8 & 5.88 & 3.68 & 0 \\
\hline \multirow[t]{6}{*}{112} & A & $a$ & 1.51 & 0 & 1.34 & 3.69 \\
\hline & & $b$ & 1.99 & 5.07 & 0 & 0 \\
\hline & & C & 4.17 & 5.5 & 3.45 & 5.59 \\
\hline & LB & $a$ & 0 & 0 & 0 & 0 \\
\hline & & $b$ & 0 & 0 & 0 & 0 \\
\hline & & C & 0 & 0 & 0 & 0 \\
\hline
\end{tabular}




\begin{tabular}{|c|c|c|c|c|c|c|}
\hline & RB & a & 1.55 & 5.58 & 0 & 0 \\
\hline & & $b$ & 2.35 & 5.52 & 1.87 & 3.96 \\
\hline & & C & 3.36 & 0 & 3.14 & 6.4 \\
\hline \multirow[t]{6}{*}{113} & A & $a$ & 1.49 & 4.73 & 1.21 & 4.26 \\
\hline & & $b$ & 1.55 & 5.35 & 0.96 & 0 \\
\hline & & C & 3.48 & 5.79 & 3.19 & 5.29 \\
\hline & RB & $a$ & 1.74 & 6.74 & 1.76 & 5.15 \\
\hline & & $b$ & 2.42 & 6.87 & 1.66 & 0 \\
\hline & & C & 3.72 & 6.25 & 3.49 & 5.47 \\
\hline \multirow[t]{6}{*}{114} & LB & $a$ & 1.38 & 5.49 & 1.06 & 0 \\
\hline & & $b$ & 2.13 & 5.74 & 3.31 & 5.51 \\
\hline & & $\mathrm{C}$ & 4.31 & 5.32 & 2.26 & 4.69 \\
\hline & RB & $\mathrm{a}$ & 0 & 0 & 0 & 0 \\
\hline & & $b$ & 2.61 & 6.2 & 2.04 & 4.36 \\
\hline & & C & 4.13 & 5.45 & 3.57 & 4.79 \\
\hline \multirow[t]{9}{*}{115} & A & $a$ & 1.49 & 5.54 & 1.45 & 5.05 \\
\hline & & $b$ & 1.88 & 4.72 & 1.64 & 0 \\
\hline & & C & 4.04 & 3.7 & 3.88 & 3.72 \\
\hline & LB & $a$ & 0 & 0 & 0 & 0 \\
\hline & & $b$ & 0 & 0 & 0 & 0 \\
\hline & & C & 3.56 & 5.11 & 3.41 & 4.98 \\
\hline & RB & $a$ & 1.25 & 0 & 1.7 & 0 \\
\hline & & $b$ & 0 & 0 & 0 & 0 \\
\hline & & $\mathrm{C}$ & 2.97 & 0 & 2.85 & 0 \\
\hline \multirow[t]{3}{*}{116} & A & $a$ & 1.57 & 5.51 & 1.59 & 5.24 \\
\hline & & $b$ & 1.92 & 4.87 & 1.57 & 5.57 \\
\hline & & C & 3.92 & 6.06 & 4.24 & 5.41 \\
\hline \multirow[t]{9}{*}{117} & A & $a$ & 1.49 & 6.66 & 1.37 & 5.16 \\
\hline & & $b$ & 1.83 & 4.89 & 1.51 & 4.25 \\
\hline & & C & 4.01 & 6.58 & 3.81 & 6.35 \\
\hline & LB & $a$ & 0 & 0 & 3.91 & 5.62 \\
\hline & & $b$ & 0 & 0 & 2 & 0 \\
\hline & & C & 4.7 & 5.48 & 0 & 0 \\
\hline & RB & $a$ & 1.47 & 5.65 & 0 & 0 \\
\hline & & $b$ & 0 & 0 & 0 & 0 \\
\hline & & C & 0 & 0 & 0 & 0 \\
\hline \multirow[t]{3}{*}{118} & A & $a$ & 1.59 & 0 & 1.55 & 0 \\
\hline & & $b$ & 2.32 & 5.23 & 2.13 & 5.37 \\
\hline & & $\mathrm{C}$ & 3.88 & 0 & 4.05 & 5.52 \\
\hline \multirow[t]{8}{*}{119} & A & $\mathrm{a}$ & 1.49 & 4.64 & 1.47 & 4.26 \\
\hline & & $b$ & 1.64 & 4.97 & 1.84 & 4.63 \\
\hline & & $\mathrm{C}$ & 4 & 4.14 & 3.98 & 3.88 \\
\hline & LB & $a$ & 0 & 0 & 0 & 0 \\
\hline & & $b$ & 1.83 & 5.81 & 0 & 0 \\
\hline & & C & 0 & 0 & 0 & 0 \\
\hline & RB & $a$ & 1.32 & 5.91 & 1.27 & 4.29 \\
\hline & & b & 1.39 & 6.2 & 2.42 & 5.71 \\
\hline
\end{tabular}




\begin{tabular}{|c|c|c|c|c|c|c|}
\hline & & C & 4.15 & 6.77 & 4 & 4.78 \\
\hline \multirow[t]{3}{*}{120} & A & $a$ & 1.84 & 6.67 & 1.93 & 5.64 \\
\hline & & $b$ & 2.93 & 6.14 & 2.47 & 5.75 \\
\hline & & C & 4.05 & 5.65 & 4 & 5.72 \\
\hline \multirow[t]{6}{*}{121} & A & $a$ & 1.2 & 0 & 1.62 & 6.53 \\
\hline & & $b$ & 1.91 & 0 & 2.79 & 6.95 \\
\hline & & $\mathrm{C}$ & 3.65 & 0 & 3.5 & 6.65 \\
\hline & LB & $a$ & 1.39 & 0 & 1.65 & 0 \\
\hline & & $b$ & 2.06 & 0 & 2.49 & 0 \\
\hline & & C & 3.64 & 0 & 3.46 & 0 \\
\hline \multirow[t]{6}{*}{122} & LB & $a$ & 1.72 & 6.22 & 1.53 & 0 \\
\hline & & b & 2.21 & 5.54 & 1.85 & 0 \\
\hline & & $\mathrm{C}$ & 3.73 & 5.86 & 3.87 & 0 \\
\hline & RB & $a$ & 1.37 & 5.75 & 1.8 & 4.92 \\
\hline & & $b$ & 2.03 & 6.17 & 2.34 & 4.98 \\
\hline & & C & 4.18 & 6.21 & 3.67 & 5.52 \\
\hline \multirow[t]{9}{*}{123} & A & $a$ & 1.39 & 5.9 & 0 & 0 \\
\hline & & $b$ & 2.03 & 6.43 & 2.22 & 5.89 \\
\hline & & C & 4.22 & 6.24 & 3.69 & 5.13 \\
\hline & LB & $a$ & 1.97 & 5.8 & 1.36 & 5.92 \\
\hline & & $b$ & 2.68 & 6.94 & 2.47 & 5.98 \\
\hline & & $\mathrm{C}$ & 4.3 & 6.84 & 3.61 & 5.49 \\
\hline & RB & $a$ & 1.07 & 6.03 & 1.34 & 5.4 \\
\hline & & $b$ & 1.99 & 6.44 & 2.04 & 5.31 \\
\hline & & C & 4.3 & 6.42 & 4.03 & 5.8 \\
\hline \multirow[t]{3}{*}{124} & A & $a$ & 1.51 & 5.87 & 1.59 & 5.21 \\
\hline & & $b$ & 2.27 & 6.06 & 2.38 & 5.39 \\
\hline & & C & 4.11 & 6.87 & 3.9 & 6.45 \\
\hline \multirow[t]{6}{*}{125} & A & $a$ & 1.49 & 5.56 & 1.28 & 5.54 \\
\hline & & $b$ & 2.35 & 6.11 & 2.06 & 5.45 \\
\hline & & C & 4.41 & 6.65 & 3.4 & 5.25 \\
\hline & LB & $a$ & 1.8 & 5.97 & 0 & 0 \\
\hline & & $b$ & 2.5 & 6.03 & 2.59 & 5.5 \\
\hline & & C & 4.01 & 6 & 4.26 & 5.89 \\
\hline \multirow[t]{6}{*}{126} & A & $a$ & 1.68 & 5.84 & 1.39 & 5.74 \\
\hline & & $b$ & 3.17 & 6.11 & 2.96 & 5.71 \\
\hline & & C & 4.42 & 6.11 & 4.2 & 6.49 \\
\hline & RB & a & 1.55 & 6.79 & 1.73 & 6.08 \\
\hline & & $b$ & 1.68 & 6.55 & 2.44 & 6.24 \\
\hline & & $\mathrm{C}$ & 3.4 & 7.23 & 3.69 & 6.3 \\
\hline \multirow[t]{6}{*}{127} & A & $a$ & 1.38 & 5.89 & 1.49 & 5.48 \\
\hline & & b & 2.01 & 5.29 & 1.98 & 6.27 \\
\hline & & C & 3.79 & 6.83 & 3.61 & 6.72 \\
\hline & LB & $a$ & 1.35 & 5.75 & 1.24 & 5.11 \\
\hline & & $b$ & 2.08 & 5.8 & 1.87 & 5.93 \\
\hline & & C & 4.3 & 6.69 & 3.37 & 6.2 \\
\hline 128 & A & a & 1.72 & 6.7 & 1.22 & 6.49 \\
\hline
\end{tabular}




\begin{tabular}{|c|c|c|c|c|c|c|}
\hline & & b & 2.81 & 0 & 2.32 & 0 \\
\hline & & $\mathrm{C}$ & 4.43 & 6.89 & 4.21 & 6.51 \\
\hline & LB & $a$ & 1.53 & 5.8 & 1.3 & 5.57 \\
\hline & & b & 2.06 & 0 & 2.16 & 0 \\
\hline & & $\mathrm{C}$ & 3.85 & 7.1 & 3.85 & 6.32 \\
\hline \multirow[t]{6}{*}{129} & A & $a$ & 1.41 & 6.83 & 1.49 & 5.48 \\
\hline & & $b$ & 2.3 & 5.79 & 2.51 & 5.76 \\
\hline & & C & 4.11 & 6.08 & 4.18 & 5.7 \\
\hline & $\mathrm{RB}$ & $a$ & 1.69 & 6.1 & 1.61 & 6.41 \\
\hline & & $b$ & 2.28 & 6.3 & 2.41 & 6.15 \\
\hline & & C & 4.39 & 6.7 & 4.31 & 5.8 \\
\hline \multirow[t]{3}{*}{130} & A & a & 1.82 & 5.53 & 1.26 & 5.53 \\
\hline & & $b$ & 2.23 & 5.84 & 2.24 & 5.76 \\
\hline & & C & 3.92 & 6.34 & 3.77 & 5.81 \\
\hline \multirow[t]{3}{*}{131} & A & $a$ & 1.72 & 5.22 & 1.81 & 5.53 \\
\hline & & b & 2.28 & 5.95 & 2.06 & 6.19 \\
\hline & & C & 3.89 & 6.01 & 3.84 & 6.18 \\
\hline \multirow[t]{6}{*}{132} & A & $a$ & 1.84 & 6.62 & 0 & 0 \\
\hline & & $b$ & 2.56 & 6.23 & 2.45 & 6.19 \\
\hline & & c & 4.22 & 6.25 & 4.35 & 6.27 \\
\hline & RB & $a$ & 1.32 & 5.85 & 1.46 & 5.71 \\
\hline & & $b$ & 1.97 & 5.55 & 2.18 & 5.65 \\
\hline & & C & 4.31 & 5.89 & 3.97 & 6.11 \\
\hline \multirow[t]{3}{*}{133} & A & a & 1.23 & 6.52 & 1.49 & 5.93 \\
\hline & & $\mathrm{b}$ & 1.82 & 6.41 & 2.15 & 5.95 \\
\hline & & C & 4 & 5.53 & 4.28 & 5.71 \\
\hline \multirow[t]{3}{*}{134} & A & a & 0 & 0 & 0 & 0 \\
\hline & & b & 1.99 & 6.18 & 2.16 & 6.33 \\
\hline & & $\mathrm{C}$ & 3.77 & 6.05 & 3.61 & 5.68 \\
\hline \multirow[t]{9}{*}{135} & A & $a$ & 1.57 & 6.29 & 1.84 & 5.97 \\
\hline & & $b$ & 2.19 & 6.39 & 2.35 & 4.96 \\
\hline & & $\mathrm{C}$ & 4.3 & 6.54 & 4.18 & 6.49 \\
\hline & LB & a & 1.34 & 5.73 & 1.85 & 6.27 \\
\hline & & $b$ & 2.2 & 5.62 & 2.44 & 5.89 \\
\hline & & C & 3.89 & 6.01 & 3.83 & 6.25 \\
\hline & RB & a & 1.39 & 6.22 & 1.51 & 6.31 \\
\hline & & $b$ & 2.19 & 6.04 & 2.21 & 5.66 \\
\hline & & C & 3.81 & 6.42 & 3.74 & 6.47 \\
\hline \multirow[t]{9}{*}{136} & A & a & 1.47 & 6.06 & 1.39 & 5.81 \\
\hline & & $b$ & 2.18 & 6.4 & 2.03 & 6.09 \\
\hline & & $\mathrm{C}$ & 4.38 & 6.68 & 3.55 & 5.63 \\
\hline & LB & a & 1.53 & 6.61 & 1.87 & 6.41 \\
\hline & & $b$ & 1.97 & 5.98 & 2.38 & 6.54 \\
\hline & & C & 3.81 & 6.54 & 4.35 & 6.66 \\
\hline & RB & $a$ & 1.84 & 6.56 & 1.75 & 6 \\
\hline & & $b$ & 2.16 & 6.49 & 2.11 & 5.94 \\
\hline & & C & 3.96 & 6.86 & 3.97 & 5.76 \\
\hline
\end{tabular}




\begin{tabular}{|r|r|r|r|r|r|r|}
\hline 137 & $\mathrm{~A}$ & $\mathrm{a}$ & 1.43 & 5.62 & 1.45 & 6.02 \\
\hline & & $\mathrm{b}$ & 2.18 & 5.63 & 1.99 & 5.47 \\
\hline & & $\mathrm{c}$ & 3.61 & 5.89 & 4.01 & 5.72 \\
\hline 138 & $\mathrm{~A}$ & $\mathrm{a}$ & 1.38 & 5.81 & 1.49 & 6.08 \\
\hline & & $\mathrm{b}$ & 2.32 & 5.46 & 2.27 & 5.73 \\
\hline & & $\mathrm{c}$ & 3.65 & 6.14 & 3.89 & 6.11 \\
\hline & $\mathrm{A}$ & $\mathrm{a}$ & 1.4 & 5.92 & 1.5 & 5.46 \\
\hline & & $\mathrm{b}$ & 1.96 & 5.65 & 2.21 & 5.45 \\
\hline & & $\mathrm{c}$ & 3.87 & 6.41 & 3.7 & 5.98 \\
\hline & $\mathrm{RB}$ & $\mathrm{a}$ & 1.48 & 6.78 & 1.51 & 5.96 \\
\hline & & $\mathrm{b}$ & 2 & 6.79 & 2.37 & 5.59 \\
\hline & & $\mathrm{c}$ & 4.06 & 6.81 & 3.74 & 6.53 \\
\hline & $\mathrm{A}$ & $\mathrm{a}$ & 1.37 & 6.17 & 1.58 & 5.82 \\
\hline & & $\mathrm{b}$ & 1.84 & 5.74 & 2.27 & 5.94 \\
\hline & & $\mathrm{c}$ & 3.92 & 6.34 & 3.76 & 6.23 \\
\hline
\end{tabular}

\begin{tabular}{|c|c|c|c|c|c|c|}
\hline \multirow[b]{2}{*}{ Mandible \# } & \multirow[b]{2}{*}{ Area } & \multirow[b]{2}{*}{ Defect ID } & \multicolumn{2}{|c|}{ Conventional } & \multicolumn{2}{|c|}{ Renderings } \\
\hline & & & width & length & width & length \\
\hline \multirow[t]{9}{*}{101} & $A$ & $\mathrm{a}$ & 0.96 & 6.03 & 1.16 & 6 \\
\hline & & $\mathrm{b}$ & 2.64 & 5.77 & 2.9 & 5.81 \\
\hline & & $\mathrm{c}$ & 4.24 & 5.99 & 4.45 & 5.42 \\
\hline & LB & $a$ & 1.02 & 5.4 & 0.95 & 4.41 \\
\hline & & $b$ & 2.05 & 5.55 & 1.95 & 5.77 \\
\hline & & $\mathrm{c}$ & 4.01 & 5.95 & 4.33 & 6.01 \\
\hline & $\mathrm{RB}$ & $a$ & 0.84 & 1.69 & 1.78 & 1.58 \\
\hline & & $b$ & 1.04 & 3.53 & 1.25 & 1.69 \\
\hline & & c & 3.95 & 6.16 & 4.22 & 4.71 \\
\hline \multirow[t]{9}{*}{102} & A & $\mathrm{a}$ & 0 & 0 & 0 & 0 \\
\hline & & $b$ & 2.01 & 5.95 & 2.28 & 4.95 \\
\hline & & $\mathrm{c}$ & 3.82 & 5.78 & 3.76 & 5.99 \\
\hline & LB & $\mathrm{a}$ & 1.76 & 4.35 & 1.53 & 3.08 \\
\hline & & $b$ & 3.85 & 6.22 & 3.74 & 5.61 \\
\hline & & $\mathrm{c}$ & 0 & 0 & 0 & 0 \\
\hline & $\mathrm{RB}$ & $a$ & 0 & 0 & 0 & 0 \\
\hline & & $b$ & 0 & 0 & 0 & 0 \\
\hline & & $\mathrm{c}$ & 0 & 0 & 0 & 0 \\
\hline \multirow[t]{8}{*}{103} & A & $a$ & 1.56 & 5.27 & 1.54 & 3.85 \\
\hline & & $b$ & 2.21 & 6.56 & 1.95 & 5.95 \\
\hline & & $\mathrm{C}$ & 4.3 & 7.73 & 4.07 & 7.1 \\
\hline & LB & $a$ & 0 & 0 & 0 & 0 \\
\hline & & $b$ & 0 & 0 & 0 & 0 \\
\hline & & C & 0 & 0 & 3.74 & 4.98 \\
\hline & RB & $a$ & 1.41 & 6.31 & 0 & 0 \\
\hline & & $b$ & 2.31 & 0 & 1.85 & 5.65 \\
\hline
\end{tabular}




\begin{tabular}{|c|c|c|c|c|c|c|}
\hline & & C & 4.52 & 0 & 3.98 & 5.88 \\
\hline \multirow[t]{9}{*}{104} & A & $a$ & 0.82 & 6.58 & 0.75 & 6.11 \\
\hline & & b & 1.78 & 6.08 & 1.57 & 5.22 \\
\hline & & C & 3.98 & 6.33 & 3.93 & 6 \\
\hline & LB & $a$ & 1.57 & 0 & 1.03 & 5.64 \\
\hline & & $b$ & 1.96 & 6.13 & 1.91 & 6.19 \\
\hline & & $\mathrm{C}$ & 4.1 & 6.78 & 3.74 & 6.98 \\
\hline & RB & a & 1.3 & 6.17 & 1.09 & 4.4 \\
\hline & & $b$ & 1.75 & 6.82 & 0 & 0 \\
\hline & & $\mathrm{C}$ & 3.98 & 5.9 & 4.16 & 6.06 \\
\hline \multirow[t]{6}{*}{105} & A & $a$ & 1.11 & 0 & 1.73 & 5.23 \\
\hline & & b & 1.66 & 5.32 & 2.06 & 5.53 \\
\hline & & $\mathrm{C}$ & 4.16 & 6.61 & 4.24 & 6.66 \\
\hline & LB & $a$ & 0 & 0 & 0 & 0 \\
\hline & & $b$ & 2.22 & 6.35 & 0 & 0 \\
\hline & & C & 3.75 & 6.22 & 4.17 & 6.54 \\
\hline \multirow[t]{3}{*}{106} & A & $a$ & 1.34 & 5.82 & 1.87 & 6.06 \\
\hline & & $b$ & 1.95 & 6.93 & 2.38 & 7.53 \\
\hline & & C & 4.15 & 6.72 & 4.76 & 7.71 \\
\hline \multirow[t]{9}{*}{107} & A & $\mathrm{a}$ & 1.13 & 6.03 & 1.89 & 4.8 \\
\hline & & $b$ & 2.17 & 5.83 & 2.07 & 5.96 \\
\hline & & $\mathrm{C}$ & 4.35 & 5.62 & 4.03 & 5.62 \\
\hline & LB & $\mathrm{a}$ & 1.45 & 0 & 1.24 & 0 \\
\hline & & $b$ & 2.76 & 5.87 & 2.31 & 0 \\
\hline & & C & 4.1 & 5.29 & 3.88 & 0 \\
\hline & RB & $a$ & 1.41 & 6.29 & 1.41 & 5.3 \\
\hline & & $b$ & 1.87 & 6.51 & 2.25 & 6.02 \\
\hline & & C & 3.95 & 6.58 & 3.82 & 6.46 \\
\hline \multirow[t]{9}{*}{108} & A & $a$ & 1.31 & 5.72 & 1.44 & 0 \\
\hline & & $b$ & 1.45 & 4.8 & 1.27 & 4.37 \\
\hline & & C & 3.82 & 5.43 & 3.62 & 5.48 \\
\hline & LB & $a$ & 0 & 0 & 1.83 & 5 \\
\hline & & $b$ & 1.46 & 5.76 & 3.98 & 5.39 \\
\hline & & C & 3.94 & 5.59 & 0 & 0 \\
\hline & RB & a & 0.98 & 6.16 & 1.05 & 3.95 \\
\hline & & $b$ & 1.66 & 6.11 & 1.64 & 4.4 \\
\hline & & $\mathrm{C}$ & 4.16 & 5.42 & 3.42 & 4.95 \\
\hline \multirow[t]{6}{*}{109} & A & $a$ & 1.25 & 0 & 1.35 & 5.33 \\
\hline & & b & 1.87 & 0 & 1.56 & 4.59 \\
\hline & & C & 3.69 & 0 & 2.46 & 5.72 \\
\hline & $\mathrm{RB}$ & $a$ & 0 & 0 & 1.79 & 0 \\
\hline & & $b$ & 0 & 0 & 2.05 & 0 \\
\hline & & C & 0 & 0 & 3.92 & 6.56 \\
\hline \multirow[t]{4}{*}{110} & A & a & 0 & 0 & 0 & 0 \\
\hline & & $b$ & 0 & 0 & 0 & 0 \\
\hline & & $C$ & 4.34 & 5.94 & 4.24 & 5.18 \\
\hline & LB & a & 0 & 0 & 0 & 0 \\
\hline
\end{tabular}




\begin{tabular}{|c|c|c|c|c|c|c|}
\hline & & $b$ & 0 & 0 & 0 & 0 \\
\hline & & C & 0 & 0 & 3.07 & 0 \\
\hline & RB & $a$ & 1.21 & 0 & 0 & 0 \\
\hline & & $b$ & 1.53 & 5.48 & 0 & 0 \\
\hline & & $\mathrm{C}$ & 3.65 & 5.05 & 4.1 & 0 \\
\hline \multirow[t]{6}{*}{111} & A & $a$ & 1.6 & 6.64 & 1.76 & 5.99 \\
\hline & & $b$ & 2.66 & 0 & 2.53 & 0 \\
\hline & & C & 4.11 & 0 & 4.31 & 6.4 \\
\hline & LB & $a$ & 1.46 & 5.62 & 0 & 0 \\
\hline & & $b$ & 2.22 & 6.32 & 0 & 0 \\
\hline & & C & 4.13 & 6.38 & 4.02 & 0 \\
\hline \multirow[t]{9}{*}{112} & A & $a$ & 1.69 & 0 & 1.28 & 0 \\
\hline & & $b$ & 2.54 & 0 & 1.76 & 4.07 \\
\hline & & C & 3.74 & 6.03 & 3.39 & 5.95 \\
\hline & LB & $a$ & 0 & 0 & 0 & 0 \\
\hline & & $b$ & 0 & 0 & 0 & 0 \\
\hline & & C & 0 & 0 & 0 & 0 \\
\hline & RB & $a$ & 1.55 & 5.58 & 0 & 0 \\
\hline & & $b$ & 2.35 & 5.52 & 1.65 & 4.83 \\
\hline & & C & 3.36 & 0 & 2.68 & 6.13 \\
\hline \multirow[t]{6}{*}{113} & A & $a$ & 1.35 & 6.39 & 1.29 & 4.72 \\
\hline & & $b$ & 1.86 & 5.07 & 0.98 & 0 \\
\hline & & C & 3.74 & 5.4 & 3.37 & 5.03 \\
\hline & RB & $a$ & 1.79 & 0 & 2.34 & 5.25 \\
\hline & & $b$ & 2.16 & 7.01 & 0 & 0 \\
\hline & & $C$ & 3.7 & 6.36 & 3.44 & 5.43 \\
\hline \multirow[t]{6}{*}{114} & LB & a & 1.51 & 0 & 1.73 & 5.57 \\
\hline & & $b$ & 0 & 0 & 0 & 0 \\
\hline & & C & 3.9 & 5.36 & 3.61 & 4.72 \\
\hline & $\mathrm{RB}$ & $a$ & 0 & 0 & 0 & 0 \\
\hline & & $b$ & 1.89 & 5.77 & 1.98 & 4.88 \\
\hline & & $C$ & 4.49 & 5.69 & 4.26 & 5.43 \\
\hline \multirow[t]{9}{*}{115} & A & $a$ & 1.23 & 5.98 & 1.19 & 5.14 \\
\hline & & $b$ & 1.5 & 5.62 & 1.65 & 4.25 \\
\hline & & C & 3.64 & 3.57 & 3.42 & 3.73 \\
\hline & LB & $a$ & 0 & 0 & 0 & 0 \\
\hline & & $b$ & 0 & 0 & 0 & 0 \\
\hline & & C & 4.09 & 5.12 & 4.42 & 4.79 \\
\hline & $\mathrm{RB}$ & $a$ & 0 & 0 & 0 & 0 \\
\hline & & $b$ & 0 & 0 & 0 & 0 \\
\hline & & $\mathrm{C}$ & 3.89 & 0 & 3.41 & 0 \\
\hline \multirow[t]{3}{*}{116} & A & $a$ & 1.34 & 5.39 & 1.47 & 5.15 \\
\hline & & $b$ & 2.28 & 5.78 & 2.28 & 5.39 \\
\hline & & C & 4.13 & 5.62 & 4.27 & 5.79 \\
\hline \multirow[t]{3}{*}{117} & A & $a$ & 1.58 & 6.42 & 1.49 & 4.31 \\
\hline & & $b$ & 2.25 & 6.03 & 1.7 & 4.07 \\
\hline & & C & 4.15 & 6.26 & 4.05 & 6.07 \\
\hline
\end{tabular}




\begin{tabular}{|c|c|c|c|c|c|c|}
\hline & LB & a & 0 & 0 & 0 & 0 \\
\hline & & $b$ & 0 & 0 & 0 & 0 \\
\hline & & C & 4.7 & 5.48 & 0 & 0 \\
\hline & $\mathrm{RB}$ & $a$ & 1.47 & 5.65 & 1.58 & 0 \\
\hline & & $\mathrm{b}$ & 0 & 0 & 0 & 0 \\
\hline & & $\mathrm{C}$ & 0 & 0 & 2 & 3.8 \\
\hline \multirow[t]{3}{*}{118} & A & $a$ & 1.71 & 0 & 2.01 & 0 \\
\hline & & $b$ & 2.3 & 5.41 & 1.37 & 5.11 \\
\hline & & C & 3.68 & 6.71 & 3.66 & 5.82 \\
\hline \multirow[t]{9}{*}{119} & A & $a$ & 1.6 & 4.74 & 1.38 & 4.38 \\
\hline & & $b$ & 1.91 & 5.18 & 1.79 & 4.35 \\
\hline & & $\mathrm{C}$ & 4.02 & 4.36 & 3.79 & 3.93 \\
\hline & LB & $a$ & 1.24 & 4.55 & 0 & 0 \\
\hline & & $b$ & 2.06 & 5.73 & 0 & 0 \\
\hline & & $\mathrm{C}$ & 0 & 0 & 0 & 0 \\
\hline & $\mathrm{RB}$ & $a$ & 1.31 & 5.99 & 1.62 & 4.08 \\
\hline & & $b$ & 1.58 & 6.15 & 2.13 & 5.71 \\
\hline & & C & 4.16 & 6.44 & 3.89 & 3.97 \\
\hline \multirow[t]{3}{*}{120} & A & $a$ & 1.64 & 6.45 & 1.87 & 5.9 \\
\hline & & $b$ & 1.73 & 5.85 & 2.14 & 5.48 \\
\hline & & C & 4.26 & 5.38 & 4.15 & 5.98 \\
\hline \multirow[t]{6}{*}{121} & A & $a$ & 1.24 & 0 & 2.11 & 6.02 \\
\hline & & $b$ & 2.95 & 0 & 2.32 & 6.39 \\
\hline & & $\mathrm{C}$ & 3.34 & 0 & 4.11 & 6.64 \\
\hline & LB & $a$ & 1.58 & 0 & 1.57 & 0 \\
\hline & & $b$ & 2.67 & 0 & 2.52 & 0 \\
\hline & & $\mathrm{C}$ & 3.18 & 0 & 3.89 & 0 \\
\hline \multirow[t]{6}{*}{122} & LB & $a$ & 1.69 & 6.22 & 1.4 & 5.27 \\
\hline & & $b$ & 2.12 & 5.91 & 1.97 & 5.09 \\
\hline & & C & 3.83 & 5.92 & 3.77 & 0 \\
\hline & $\mathrm{RB}$ & $a$ & 1.35 & 5.74 & 1.49 & 5.76 \\
\hline & & $b$ & 2.23 & 5.73 & 2.09 & 4.98 \\
\hline & & C & 3.86 & 5.93 & 3.75 & 5.74 \\
\hline \multirow[t]{9}{*}{123} & A & $a$ & 1.77 & 6.18 & 1.15 & 5.98 \\
\hline & & $\mathrm{b}$ & 2.4 & 5.98 & 2.12 & 6.13 \\
\hline & & $\mathrm{C}$ & 4.21 & 6.47 & 3.88 & 5.58 \\
\hline & LB & $a$ & 1.7 & 5.8 & 1.86 & 5.87 \\
\hline & & $b$ & 2.24 & 7.32 & 2.41 & 7.02 \\
\hline & & $\mathrm{C}$ & 4.8 & 6 & 4.6 & 6.89 \\
\hline & $\mathrm{RB}$ & $a$ & 1.45 & 6 & 1.24 & 5.95 \\
\hline & & $b$ & 2.35 & 5.7 & 2.23 & 5.52 \\
\hline & & C & 3.96 & 7.29 & 4.2 & 5.92 \\
\hline \multirow[t]{3}{*}{124} & A & $a$ & 1.74 & 5.74 & 1.57 & 5.5 \\
\hline & & $b$ & 2.14 & 5.37 & 2.04 & 5.36 \\
\hline & & $\mathrm{C}$ & 4.17 & 5.91 & 4.07 & 5.9 \\
\hline \multirow[t]{2}{*}{125} & A & $a$ & 1.23 & 5.08 & 1.2 & 4.78 \\
\hline & & $b$ & 1.8 & 6.17 & 2.25 & 6.11 \\
\hline
\end{tabular}




\begin{tabular}{|c|c|c|c|c|c|c|}
\hline & & C & 3.58 & 6.48 & 3.31 & 5.76 \\
\hline & LB & $a$ & 1.57 & 6.3 & 1.8 & 5.83 \\
\hline & & b & 2.17 & 6.57 & 2.71 & 5.51 \\
\hline & & C & 4.56 & 6.58 & 3.72 & 6.48 \\
\hline \multirow[t]{6}{*}{126} & A & $a$ & 1.48 & 6.71 & 1.53 & 5.58 \\
\hline & & $b$ & 2.39 & 6.78 & 2.82 & 6.31 \\
\hline & & $\mathrm{C}$ & 4.23 & 6.91 & 4.24 & 6.38 \\
\hline & RB & a & 1.61 & 6.96 & 1.57 & 6.43 \\
\hline & & $b$ & 2.66 & 6.74 & 2.53 & 6.81 \\
\hline & & C & 4.55 & 6.95 & 3.71 & 6.94 \\
\hline \multirow[t]{6}{*}{127} & A & $a$ & 1.3 & 5.16 & 1.12 & 5.53 \\
\hline & & b & 2.07 & 5.97 & 1.97 & 6.05 \\
\hline & & $\mathrm{C}$ & 4.01 & 6.79 & 3.89 & 6.73 \\
\hline & LB & $a$ & 1.42 & 6.09 & 1.34 & 5.89 \\
\hline & & $b$ & 1.96 & 5.6 & 1.91 & 5.59 \\
\hline & & C & 4.07 & 5.98 & 4.32 & 6.37 \\
\hline \multirow[t]{6}{*}{128} & A & $a$ & 1.61 & 6.53 & 1.39 & 7.24 \\
\hline & & $b$ & 2.64 & 0 & 2.24 & 0 \\
\hline & & C & 4.2 & 6.26 & 4.28 & 6.62 \\
\hline & LB & $\mathrm{a}$ & 1.5 & 5.86 & 1.6 & 5.84 \\
\hline & & $b$ & 2.19 & 0 & 2.41 & 0 \\
\hline & & $\mathrm{C}$ & 4.09 & 6.36 & 4.31 & 6.4 \\
\hline \multirow[t]{6}{*}{129} & A & $a$ & 1.52 & 6.44 & 1.62 & 6.09 \\
\hline & & $b$ & 2.41 & 6.18 & 2.27 & 5.74 \\
\hline & & C & 4.07 & 5.98 & 4.36 & 5.7 \\
\hline & RB & $a$ & 1.76 & 5.99 & 1.55 & 6.74 \\
\hline & & $b$ & 2.3 & 7.02 & 2.33 & 6.09 \\
\hline & & C & 4.29 & 6.42 & 4.27 & 6.13 \\
\hline \multirow[t]{3}{*}{130} & A & $a$ & 1.7 & 5.6 & 1.39 & 5.51 \\
\hline & & $b$ & 2.31 & 5.65 & 2.28 & 5.67 \\
\hline & & C & 4.11 & 6.2 & 4.08 & 6.09 \\
\hline \multirow[t]{3}{*}{131} & A & $a$ & 1.74 & 5.71 & 1.83 & 5.78 \\
\hline & & $b$ & 2.31 & 6.13 & 2.14 & 6.05 \\
\hline & & C & 4.23 & 6.23 & 3.82 & 6.18 \\
\hline \multirow[t]{6}{*}{132} & A & a & 1.81 & 6.26 & 1.34 & 5.83 \\
\hline & & $b$ & 2.28 & 6.48 & 2.48 & 6.17 \\
\hline & & $\mathrm{C}$ & 4.21 & 6.19 & 4.35 & 6.49 \\
\hline & RB & $\mathrm{a}$ & 1.53 & 6.04 & 1.86 & 5.71 \\
\hline & & b & 1.89 & 6.23 & 2.29 & 6.71 \\
\hline & & C & 4.11 & 5.95 & 4.42 & 6.52 \\
\hline \multirow[t]{3}{*}{133} & A & $a$ & 1.53 & 6.2 & 1.47 & 6.17 \\
\hline & & $b$ & 2.13 & 6.38 & 2.06 & 5.99 \\
\hline & & C & 4.42 & 5.69 & 4.08 & 5.45 \\
\hline \multirow[t]{3}{*}{134} & A & a & 0 & 0 & 1.62 & 5.88 \\
\hline & & $b$ & 2.13 & 6.44 & 2.33 & 6.25 \\
\hline & & $\mathrm{C}$ & 4.04 & 6.04 & 3.82 & 5.72 \\
\hline 135 & A & a & 1.22 & 5.81 & 1.67 & 6.13 \\
\hline
\end{tabular}




\begin{tabular}{|c|c|c|c|c|c|c|}
\hline & & $b$ & 1.61 & 6.22 & 2.36 & 5.69 \\
\hline & & C & 3.74 & 6.32 & 4.33 & 6.21 \\
\hline & LB & $a$ & 1.37 & 5.83 & 1.68 & 5.94 \\
\hline & & $b$ & 2.27 & 5.74 & 2.29 & 6.46 \\
\hline & & C & 4 & 6.35 & 4.33 & 6.37 \\
\hline & RB & $a$ & 1.41 & 5.66 & 1.59 & 6.18 \\
\hline & & $b$ & 2.11 & 5.26 & 2.26 & 5.93 \\
\hline & & C & 4.11 & 6.5 & 3.65 & 6.37 \\
\hline \multirow[t]{9}{*}{136} & A & $a$ & 1.48 & 5.92 & 1.48 & 6.12 \\
\hline & & $b$ & 2.34 & 6.77 & 2.34 & 5.83 \\
\hline & & C & 4.3 & 6.64 & 4.15 & 5.97 \\
\hline & LB & $a$ & 1.61 & 6.33 & 1.77 & 5.83 \\
\hline & & $b$ & 2.2 & 6.02 & 2.15 & 6.03 \\
\hline & & C & 3.96 & 6.78 & 3.8 & 6.43 \\
\hline & RB & $a$ & 1.49 & 6.38 & 1.83 & 6.12 \\
\hline & & $b$ & 2.25 & 6.24 & 2.18 & 5.98 \\
\hline & & $\mathrm{C}$ & 4.24 & 6.82 & 4.15 & 5.91 \\
\hline \multirow[t]{3}{*}{137} & A & $a$ & 1.33 & 6.17 & 1.45 & 5.82 \\
\hline & & $b$ & 1.9 & 6.54 & 2.11 & 5.69 \\
\hline & & C & 3.93 & 6.05 & 3.85 & 5.98 \\
\hline \multirow[t]{3}{*}{138} & A & $a$ & 1.6 & 5.87 & 1.66 & 5.99 \\
\hline & & $b$ & 2.43 & 5.47 & 2.3 & 5.57 \\
\hline & & C & 4.21 & 6.56 & 4.03 & 6.02 \\
\hline \multirow[t]{6}{*}{139} & A & $a$ & 1.32 & 5.95 & 1.4 & 5.4 \\
\hline & & $b$ & 2.04 & 5.61 & 2.27 & 5.89 \\
\hline & & C & 4.1 & 6.16 & 4.07 & 6.3 \\
\hline & $\mathrm{RB}$ & $a$ & 1.53 & 6.69 & 1.57 & 6.44 \\
\hline & & $b$ & 2 & 6.81 & 2.19 & 6.23 \\
\hline & & $\mathrm{C}$ & 3.67 & 6.51 & 3.75 & 6.71 \\
\hline \multirow[t]{3}{*}{140} & A & $a$ & 1.43 & 5.89 & 1.5 & 6.1 \\
\hline & & $b$ & 2.28 & 6.45 & 2.21 & 6.46 \\
\hline & & C & 4.16 & 6.14 & 4.04 & 6.28 \\
\hline
\end{tabular}

\begin{tabular}{|c|c|c|c|c|c|c|}
\hline \multicolumn{7}{|c|}{ Intracortical Simulated Defects : 12 impulses +20 degrees } \\
\hline \multirow[b]{2}{*}{ Mandible \# } & \multirow[b]{2}{*}{ Area } & \multirow[b]{2}{*}{ Defect ID } & \multicolumn{2}{|c|}{ Conventional } & \multicolumn{2}{|c|}{ Renderings } \\
\hline & & & width & length & width & length \\
\hline 101 & A & $\mathrm{a}$ & 0.91 & 6.18 & 0.94 & 6.1 \\
\hline & & b & 2.39 & 5.78 & 5.5 & 2.42 \\
\hline & & c & 3.95 & 6 & 4.08 & 5.59 \\
\hline & LB & $\mathrm{a}$ & 1.06 & 5.41 & 1.12 & 4.72 \\
\hline & & $\mathrm{b}$ & 2.01 & 6 & 2.34 & 4.35 \\
\hline & & c & 4.41 & 5.98 & 3.82 & 6.59 \\
\hline & RB & $\mathrm{a}$ & 1.13 & 1.54 & 2.01 & 1.82 \\
\hline & & b & 0 & 0 & 1.31 & 2.38 \\
\hline & & C & 4.47 & 6.11 & 4.88 & 6.37 \\
\hline
\end{tabular}




\begin{tabular}{|c|c|c|c|c|c|c|}
\hline 102 & A & a & 1.46 & 5.52 & 1.19 & 4.96 \\
\hline & & $b$ & 0 & 0 & 0 & 0 \\
\hline & & $\mathrm{C}$ & 4.33 & 5.9 & 4.29 & 5.84 \\
\hline & LB & $a$ & 0 & 0 & 1.26 & 2.58 \\
\hline & & $b$ & 3.91 & 0 & 0 & 0 \\
\hline & & $\mathrm{C}$ & 3.91 & 6.47 & 3.76 & 7.04 \\
\hline & RB & $a$ & 0 & 0 & 0 & 0 \\
\hline & & $b$ & 0 & 0 & 0 & 0 \\
\hline & & C & 0 & 0 & 0 & 0 \\
\hline \multirow[t]{9}{*}{103} & A & $a$ & 1.49 & 5.53 & 1.33 & 4.5 \\
\hline & & $b$ & 2.24 & 6.96 & 1.79 & 2.2 \\
\hline & & C & 4.48 & 7.44 & 4.23 & 4.77 \\
\hline & LB & a & 0 & 0 & 0 & 0 \\
\hline & & $b$ & 0 & 0 & 0 & 0 \\
\hline & & $\mathrm{C}$ & 0 & 0 & 0 & 0 \\
\hline & RB & a & 0 & 0 & 0 & 0 \\
\hline & & b & 2.12 & 5.95 & 0 & 0 \\
\hline & & C & 4.29 & 0 & 4.11 & 5.76 \\
\hline \multirow[t]{9}{*}{104} & A & a & 1.1 & 6.37 & 1.13 & 5.06 \\
\hline & & b & 2.11 & 6.47 & 1.89 & 5.41 \\
\hline & & C & 2.89 & 6.3 & 2.38 & 5.93 \\
\hline & LB & a & 1.57 & 0 & 1.63 & 6.6 \\
\hline & & $b$ & 1.98 & 6.17 & 1.97 & 5.91 \\
\hline & & C & 4.48 & 6.94 & 4.28 & 7.12 \\
\hline & RB & $a$ & 1.68 & 6.16 & 1.12 & 4.51 \\
\hline & & $b$ & 2.13 & 6.75 & 0 & 0 \\
\hline & & C & 4.09 & 6.12 & 3.97 & 5.59 \\
\hline \multirow[t]{6}{*}{105} & A & a & 0.93 & 0 & 1.61 & 5.19 \\
\hline & & b & 1.74 & 5.04 & 1.99 & 5.22 \\
\hline & & C & 3.99 & 6.29 & 4.38 & 6.61 \\
\hline & LB & a & 0 & 0 & 0 & 0 \\
\hline & & b & 2.34 & 5.8 & 0 & 0 \\
\hline & & C & 3.17 & 6.16 & 3.53 & 6.14 \\
\hline \multirow[t]{3}{*}{106} & A & $a$ & 1.65 & 5.8 & 2.13 & 5.42 \\
\hline & & b & 2.36 & 6.88 & 2.73 & 8.44 \\
\hline & & C & 4.4 & 5.92 & 5.02 & 8.02 \\
\hline \multirow[t]{9}{*}{107} & A & a & 1.32 & 6.09 & 1.42 & 5.02 \\
\hline & & b & 1.9 & 5.88 & 1.95 & 5.73 \\
\hline & & $\mathrm{C}$ & 4.1 & 5.67 & 4.18 & 5.64 \\
\hline & LB & a & 1.56 & 0 & 1.52 & 0 \\
\hline & & b & 2.67 & 6.23 & 2.66 & 0 \\
\hline & & $C$ & 3.87 & 5.4 & 3.94 & 0 \\
\hline & RB & a & 1.22 & 6.41 & 1.26 & 5.4 \\
\hline & & b & 2.13 & 6.02 & 1.93 & 6.13 \\
\hline & & $\mathrm{C}$ & 3.86 & 6.32 & 3.52 & 6.87 \\
\hline \multirow[t]{2}{*}{108} & A & a & 1.08 & 5.85 & 1.18 & 4.32 \\
\hline & & b & 1.39 & 5.55 & 0 & 0 \\
\hline
\end{tabular}




\begin{tabular}{|c|c|c|c|c|c|c|}
\hline & & C & 4.38 & 5.95 & 4.02 & 5.6 \\
\hline & LB & $a$ & 0 & 0 & 2 & 4.97 \\
\hline & & $b$ & 1.71 & 5 & 3.17 & 5.26 \\
\hline & & $\mathrm{C}$ & 3.82 & 5.6 & 0 & 0 \\
\hline & $\mathrm{RB}$ & $a$ & 1.53 & 6.62 & 1.05 & 4.17 \\
\hline & & $b$ & 2.11 & 5.95 & 1.65 & 4.66 \\
\hline & & $\mathrm{C}$ & 3.95 & 5.51 & 4.03 & 5.28 \\
\hline \multirow[t]{6}{*}{109} & A & $a$ & 1.49 & 0 & 1.04 & 4.13 \\
\hline & & $b$ & 2.03 & 0 & 1.69 & 4.49 \\
\hline & & $\mathrm{C}$ & 3.39 & 0 & 1.78 & 4.48 \\
\hline & RB & $a$ & 0 & 0 & 1.57 & 0 \\
\hline & & $b$ & 0 & 0 & 2.21 & 0 \\
\hline & & $\mathrm{C}$ & 0 & 0 & 3.39 & 6.47 \\
\hline \multirow[t]{9}{*}{110} & A & $a$ & 0 & 0 & 0 & 0 \\
\hline & & $b$ & 0 & 0 & 0 & 0 \\
\hline & & C & 4.27 & 5.9 & 4.18 & 5.08 \\
\hline & LB & $a$ & 0 & 0 & 0 & 0 \\
\hline & & $b$ & 0 & 0 & 0 & 0 \\
\hline & & $\mathrm{C}$ & 0 & 0 & 3.3 & 5.77 \\
\hline & RB & $a$ & 1.1 & 0 & 1.98 & 0 \\
\hline & & $b$ & 1.34 & 5.31 & 0 & 0 \\
\hline & & $\mathrm{C}$ & 3.83 & 5.22 & 3.94 & 0 \\
\hline \multirow[t]{6}{*}{111} & A & $a$ & 2.2 & 6.04 & 1.47 & 6.98 \\
\hline & & $b$ & 2.75 & 0 & 2.79 & 0 \\
\hline & & C & 4.31 & 6.85 & 4.59 & 6.75 \\
\hline & LB & $a$ & 1.89 & 5.92 & 0 & 0 \\
\hline & & $b$ & 2.59 & 5.85 & 0 & 0 \\
\hline & & C & 3.85 & 6.34 & 4.21 & 0 \\
\hline \multirow[t]{9}{*}{112} & A & a & 1.28 & 0 & 1.62 & 0 \\
\hline & & $b$ & 2.21 & 0 & 2.35 & 4.14 \\
\hline & & $C$ & 4.25 & 6.31 & 4.14 & 6.29 \\
\hline & LB & $\mathrm{a}$ & 3.69 & 0 & 0 & 0 \\
\hline & & b & 1.58 & 0 & 0 & 0 \\
\hline & & $\mathrm{C}$ & 0 & 0 & 0 & 0 \\
\hline & RB & $a$ & 0 & 0 & 0 & 0 \\
\hline & & $b$ & 2.09 & 6.06 & 2 & 4.4 \\
\hline & & C & 3.64 & 0 & 2.9 & 6.58 \\
\hline \multirow[t]{6}{*}{113} & A & a & 1.63 & 0 & 1.08 & 0 \\
\hline & & $b$ & 1.33 & 5.29 & 1.47 & 5 \\
\hline & & C & 4.11 & 5.17 & 3.82 & 5.49 \\
\hline & RB & $a$ & 0 & 0 & 1.89 & 0 \\
\hline & & $b$ & 2.2 & 5.76 & 0 & 0 \\
\hline & & C & 4.25 & 6.18 & 4.01 & 5.65 \\
\hline \multirow[t]{4}{*}{114} & LB & a & 1.5 & 5.56 & 0 & 0 \\
\hline & & $b$ & 2.43 & 0 & 0 & 0 \\
\hline & & $\mathrm{C}$ & 4.22 & 5.38 & 0 & 0 \\
\hline & RB & $a$ & 0 & 0 & 0 & 0 \\
\hline
\end{tabular}




\begin{tabular}{|c|c|c|c|c|c|c|}
\hline & & b & 0 & 0 & 4.18 & 4.77 \\
\hline & & $\mathrm{C}$ & 4.51 & 5.73 & 2.61 & 5.63 \\
\hline \multirow[t]{9}{*}{115} & A & a & 1.51 & 5.78 & 1.41 & 5.21 \\
\hline & & b & 1.66 & 5.5 & 1.77 & 5.03 \\
\hline & & $\mathrm{C}$ & 3.93 & 3.67 & 3.58 & 3.52 \\
\hline & LB & $a$ & 0 & 0 & 0 & 0 \\
\hline & & $b$ & 0 & 0 & 0 & 0 \\
\hline & & C & 3.99 & 5.49 & 4.89 & 4.3 \\
\hline & $\mathrm{RB}$ & $a$ & 0 & 0 & 0 & 0 \\
\hline & & $b$ & 2.05 & 0 & 0 & 0 \\
\hline & & C & 3.73 & 5.53 & 3.42 & 0 \\
\hline \multirow[t]{3}{*}{116} & A & a & 1.76 & 5.7 & 1.44 & 4.84 \\
\hline & & $b$ & 2.24 & 5.95 & 2.08 & 4.94 \\
\hline & & C & 4.15 & 5.72 & 3.95 & 5.57 \\
\hline \multirow[t]{9}{*}{117} & A & $a$ & 1.76 & 6.97 & 0 & 0 \\
\hline & & $b$ & 2.14 & 6.09 & 2.02 & 5.89 \\
\hline & & C & 4.51 & 6.1 & 4.35 & 5.99 \\
\hline & LB & $a$ & 0 & 0 & 3.77 & 5.41 \\
\hline & & $b$ & 0 & 0 & 0 & 0 \\
\hline & & c & 3.82 & 0 & 0 & 0 \\
\hline & $\mathrm{RB}$ & $a$ & 1.25 & 5.01 & 1.44 & 0 \\
\hline & & $b$ & 0 & 0 & 0 & 0 \\
\hline & & C & 3.4 & 5.12 & 0 & 0 \\
\hline \multirow[t]{3}{*}{118} & A & $a$ & 1.68 & 5.51 & 2.01 & 0 \\
\hline & & $\mathrm{b}$ & 2.16 & 5.45 & 1.72 & 4.85 \\
\hline & & 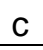 & 3.49 & 0 & 3.19 & 5.14 \\
\hline \multirow[t]{9}{*}{119} & A & a & 1.66 & 4.57 & 1.34 & 4.05 \\
\hline & & b & 1.99 & 5.03 & 1.72 & 4.42 \\
\hline & & $\mathrm{C}$ & 3.96 & 4.28 & 3.83 & 3.88 \\
\hline & LB & $a$ & 0 & 0 & 0 & 0 \\
\hline & & b & 2.31 & 6.01 & 0 & 0 \\
\hline & & $\mathrm{C}$ & 0 & 0 & 0 & 0 \\
\hline & RB & $a$ & 1.35 & 6.72 & 0 & 0 \\
\hline & & $b$ & 1.2 & 6.46 & 1.64 & 4.9 \\
\hline & & C & 4.37 & 6.35 & 3.91 & 4.7 \\
\hline \multirow[t]{3}{*}{120} & A & a & 1.03 & 5.93 & 1.18 & 5.93 \\
\hline & & $b$ & 2.14 & 5.87 & 1.68 & 5.64 \\
\hline & & C & 3.95 & 5.31 & 3.99 & 5.63 \\
\hline \multirow[t]{6}{*}{121} & A & a & 1.77 & 0 & 0 & 0 \\
\hline & & $b$ & 2.76 & 0 & 0 & 0 \\
\hline & & $\mathrm{C}$ & 3.75 & 0 & 3.52 & 6.28 \\
\hline & LB & a & 1.07 & 0 & 1.13 & 0 \\
\hline & & $b$ & 1.91 & 0 & 1.89 & 0 \\
\hline & & C & 3.09 & 0 & 3.68 & 0 \\
\hline \multirow[t]{3}{*}{122} & LB & $a$ & 1.44 & 5.83 & 1.6 & 5.08 \\
\hline & & $b$ & 2.44 & 6.05 & 1.77 & 5.15 \\
\hline & & C & 3.8 & 5.91 & 3.44 & 5.56 \\
\hline
\end{tabular}




\begin{tabular}{|c|c|c|c|c|c|c|}
\hline & $\mathrm{RB}$ & $\mathrm{a}$ & 1.36 & 5.72 & 1.55 & 0 \\
\hline & & $b$ & 2.1 & 5.35 & 2 & 5.16 \\
\hline & & C & 4.23 & 6.31 & 3.96 & 5.56 \\
\hline \multirow[t]{9}{*}{123} & A & $a$ & 1.56 & 5.95 & 1.31 & 5.56 \\
\hline & & $b$ & 1.8 & 5.65 & 1.84 & 5.63 \\
\hline & & c & 3.73 & 5.64 & 4.05 & 6.05 \\
\hline & LB & $a$ & 1.54 & 5.94 & 1.62 & 5.23 \\
\hline & & b & 1.92 & 6.75 & 2.35 & 5.92 \\
\hline & & C & 4.28 & 6.41 & 4.06 & 5.21 \\
\hline & RB & $a$ & 1.37 & 5.54 & 0 & 0 \\
\hline & & $b$ & 1.98 & 6.54 & 1.72 & 5.13 \\
\hline & & $\mathrm{C}$ & 4.11 & 6.93 & 4.22 & 6.09 \\
\hline \multirow[t]{3}{*}{124} & A & $\mathrm{a}$ & 1.47 & 5.48 & 1.15 & 5.21 \\
\hline & & $b$ & 2.27 & 5.17 & 1.88 & 5.47 \\
\hline & & $\mathrm{C}$ & 4.15 & 6.27 & 3.75 & 5.87 \\
\hline \multirow[t]{6}{*}{125} & A & $a$ & 1.63 & 5.79 & 1.43 & 5.51 \\
\hline & & $b$ & 1.91 & 6.06 & 2.56 & 5.66 \\
\hline & & C & 4.21 & 6.82 & 3.85 & 6.04 \\
\hline & LB & $a$ & 1.35 & 5.95 & 1.42 & 5.52 \\
\hline & & $b$ & 2.02 & 6.35 & 2.71 & 5.87 \\
\hline & & C & 3.7 & 5.95 & 3.67 & 6.18 \\
\hline \multirow[t]{6}{*}{126} & A & $a$ & 1.52 & 6.67 & 1.86 & 5.52 \\
\hline & & $b$ & 2.98 & 6.82 & 2.44 & 6.58 \\
\hline & & $\mathrm{C}$ & 4.79 & 6.65 & 3.82 & 6.71 \\
\hline & RB & $a$ & 1.84 & 7.1 & 1.48 & 6.25 \\
\hline & & $b$ & 2.59 & 6.61 & 2.14 & 6.52 \\
\hline & & $\mathrm{C}$ & 4.12 & 7.47 & 3.59 & 6.25 \\
\hline \multirow[t]{6}{*}{127} & A & $a$ & 1.35 & 5.86 & 1.13 & 5.24 \\
\hline & & $b$ & 2 & 5.39 & 1.72 & 6.35 \\
\hline & & $\mathrm{C}$ & 4.42 & 7.36 & 4.28 & 6.76 \\
\hline & LB & $a$ & 1.6 & 6.04 & 1.78 & 5.79 \\
\hline & & $b$ & 2.22 & 5.18 & 1.91 & 5.93 \\
\hline & & $\mathrm{C}$ & 3.63 & 5.66 & 4.11 & 7.14 \\
\hline \multirow[t]{6}{*}{128} & A & $a$ & 1.48 & 6.07 & 1.24 & 6.45 \\
\hline & & $b$ & 2.22 & 0 & 2.25 & 0 \\
\hline & & $\mathrm{C}$ & 4.05 & 6.8 & 4.31 & 6.64 \\
\hline & LB & $a$ & 1.55 & 6.03 & 1.35 & 6.33 \\
\hline & & $b$ & 2.09 & 5.83 & 2.4 & 6.14 \\
\hline & & $\mathrm{C}$ & 4.19 & 6.97 & 4.5 & 6.15 \\
\hline \multirow[t]{6}{*}{129} & $A$ & $a$ & 1.65 & 6.57 & 1.39 & 5.81 \\
\hline & & $b$ & 2.44 & 6.12 & 2.14 & 6.16 \\
\hline & & C & 4.51 & 5.91 & 4.13 & 5.8 \\
\hline & $\mathrm{RB}$ & $a$ & 1.79 & 6.23 & 1.8 & 6.39 \\
\hline & & $b$ & 2.41 & 6.3 & 2.29 & 6.6 \\
\hline & & $\mathrm{C}$ & 4.53 & 6.66 & 4.33 & 6.68 \\
\hline \multirow[t]{2}{*}{130} & A & $a$ & 1.77 & 5.71 & 1.53 & 6.02 \\
\hline & & $b$ & 2.41 & 6.14 & 2.41 & 5.8 \\
\hline
\end{tabular}




\begin{tabular}{|c|c|c|c|c|c|c|}
\hline & & C & 4.03 & 5.88 & 4.3 & 5.92 \\
\hline \multirow[t]{3}{*}{131} & A & $a$ & 1.73 & 5.51 & 1.55 & 5.58 \\
\hline & & $b$ & 2.25 & 6.12 & 2.15 & 6.02 \\
\hline & & C & 4.14 & 6.2 & 3.78 & 6.12 \\
\hline \multirow[t]{6}{*}{132} & A & $a$ & 1.42 & 5.89 & 1.32 & 5.53 \\
\hline & & b & 2.29 & 6.18 & 2.2 & 5.43 \\
\hline & & $\mathrm{C}$ & 4.05 & 6.26 & 4.21 & 6.05 \\
\hline & RB & $a$ & 1.56 & 5.92 & 1.36 & 6.04 \\
\hline & & $b$ & 1.89 & 6.12 & 2.01 & 6.49 \\
\hline & & $\mathrm{C}$ & 4.22 & 6.15 & 4.48 & 6.48 \\
\hline \multirow[t]{3}{*}{133} & A & $a$ & 1.32 & 6.25 & 1.45 & 5.81 \\
\hline & & $b$ & 1.85 & 6.05 & 1.97 & 6.2 \\
\hline & & $\mathrm{C}$ & 4.53 & 5.39 & 4.28 & 5.49 \\
\hline \multirow[t]{3}{*}{134} & A & $a$ & 1.78 & 6.43 & 1.56 & 5.98 \\
\hline & & $b$ & 2.44 & 6.24 & 2.03 & 6.18 \\
\hline & & C & 4.14 & 6.24 & 4.15 & 6.15 \\
\hline \multirow[t]{9}{*}{135} & A & $\mathrm{a}$ & 1.73 & 6.3 & 1.51 & 5.94 \\
\hline & & $b$ & 2.31 & 6.24 & 2.41 & 5.63 \\
\hline & & C & 4.14 & 6.36 & 4.1 & 6.68 \\
\hline & LB & $a$ & 1.31 & 5.73 & 1.8 & 5.91 \\
\hline & & $b$ & 1.9 & 5.79 & 2.32 & 6.16 \\
\hline & & $\mathrm{C}$ & 4.11 & 6.49 & 4.34 & 6.02 \\
\hline & RB & $a$ & 1.48 & 6.46 & 1.7 & 6 \\
\hline & & $b$ & 2.34 & 6.77 & 2.46 & 6.23 \\
\hline & & $\mathrm{C}$ & 4.09 & 6.57 & 3.79 & 6.68 \\
\hline \multirow[t]{9}{*}{136} & A & $a$ & 1.7 & 5.89 & 1.47 & 5.9 \\
\hline & & $b$ & 2.22 & 6.56 & 2.03 & 6.08 \\
\hline & & C & 4.46 & 6.62 & 3.97 & 6.02 \\
\hline & LB & $a$ & 1.49 & 6.42 & 1.42 & 5.94 \\
\hline & & $b$ & 2.23 & 6.5 & 2.21 & 6.05 \\
\hline & & $\mathrm{C}$ & 4.1 & 6.4 & 3.96 & 6.34 \\
\hline & $\mathrm{RB}$ & $a$ & 1.55 & 6.54 & 1.69 & 6.41 \\
\hline & & $b$ & 2.07 & 6.06 & 2.11 & 5.91 \\
\hline & & $\mathrm{C}$ & 4.06 & 6.51 & 4.26 & 6.04 \\
\hline \multirow[t]{3}{*}{137} & A & $a$ & 1.48 & 6.31 & 1.47 & 6.11 \\
\hline & & $b$ & 2.26 & 6.78 & 2.14 & 6 \\
\hline & & $\mathrm{C}$ & 4.26 & 6.47 & 4.19 & 5.98 \\
\hline \multirow[t]{3}{*}{138} & A & $\mathrm{a}$ & 1.54 & 6.25 & 1.58 & 5.74 \\
\hline & & $b$ & 2.25 & 6.02 & 2.16 & 5.58 \\
\hline & & $\mathrm{C}$ & 4.31 & 6.39 & 4.04 & 6.07 \\
\hline \multirow[t]{6}{*}{139} & A & $a$ & 1.28 & 5.92 & 1.49 & 5.37 \\
\hline & & $b$ & 2.07 & 6.45 & 2.24 & 5.86 \\
\hline & & C & 4.03 & 6.37 & 4.17 & 6.13 \\
\hline & RB & $a$ & 1.68 & 6.45 & 1.53 & 6.12 \\
\hline & & $b$ & 2.21 & 6.72 & 2.09 & 6.79 \\
\hline & & $\mathrm{C}$ & 4.08 & 6.79 & 3.79 & 6.85 \\
\hline 140 & A & $a$ & 1.45 & 6.24 & 1.48 & 6.16 \\
\hline
\end{tabular}




\begin{tabular}{|r|r|r|r|r|r|r|} 
& & $\mathrm{b}$ & 2.19 & 6.21 & 2.28 & 5.9 \\
\hline & & $\mathrm{c}$ & 4.21 & 6.54 & 4.12 & 6.32 \\
\hline
\end{tabular}

\begin{tabular}{|c|c|c|c|c|c|c|}
\hline \multicolumn{7}{|c|}{ Intracortical Simulated Defects : 8 impulses 90 degrees } \\
\hline \multirow[b]{2}{*}{ Mandible \# } & \multirow[b]{2}{*}{ Area } & \multirow[b]{2}{*}{ Defect ID } & \multicolumn{2}{|c|}{ Conventional } & \multicolumn{2}{|c|}{ Renderings } \\
\hline & & & width & length & width & length \\
\hline \multirow[t]{9}{*}{101} & A & $\mathrm{a}$ & 0.81 & 4.76 & 0.97 & 4.26 \\
\hline & & $\mathrm{b}$ & 2.01 & 5.81 & 2.12 & 5.23 \\
\hline & & $\mathrm{c}$ & 3.96 & 5.8 & 4.26 & 5.42 \\
\hline & LB & $a$ & 1.06 & 5.63 & 1.03 & 2.92 \\
\hline & & $b$ & 2 & 6.17 & 1.76 & 4.51 \\
\hline & & C & 3.95 & 6.02 & 4.03 & 5.85 \\
\hline & RB & $a$ & 0.98 & 2.44 & 1.33 & 2.09 \\
\hline & & $\mathrm{b}$ & 1.62 & 5.19 & 1.54 & 1.77 \\
\hline & & $\mathrm{C}$ & 3.79 & 6.09 & 3.87 & 6.2 \\
\hline \multirow[t]{9}{*}{102} & A & $a$ & 0 & 0 & 1.43 & 4.01 \\
\hline & & $b$ & 0 & 0 & 0 & 0 \\
\hline & & $\mathrm{C}$ & 3.86 & 6.1 & 3.94 & 5.69 \\
\hline & LB & $a$ & 0 & 0 & 1.81 & 4.05 \\
\hline & & $\mathrm{b}$ & 0 & 0 & 0 & 0 \\
\hline & & C & 3.83 & 5.91 & 4.06 & 5.42 \\
\hline & $\mathrm{RB}$ & $a$ & 0 & 0 & 0 & 0 \\
\hline & & $b$ & 0 & 0 & 0 & 0 \\
\hline & & $\mathrm{C}$ & 0 & 0 & 0 & 0 \\
\hline \multirow[t]{9}{*}{103} & A & $a$ & 1.07 & 5.48 & 1.04 & 3.13 \\
\hline & & $b$ & 2.09 & 6.78 & 2.17 & 4.69 \\
\hline & & C & 4.24 & 7.59 & 4.01 & 5.57 \\
\hline & LB & $a$ & 0 & 0 & 0 & 0 \\
\hline & & $\mathrm{b}$ & 0 & 0 & 0 & 0 \\
\hline & & $\mathrm{C}$ & 0 & 0 & 3 & 4.31 \\
\hline & RB & $a$ & 0 & 0 & 0 & 0 \\
\hline & & $b$ & 0 & 0 & 2.16 & 4.34 \\
\hline & & C & 4.02 & 0 & 3.71 & 6.28 \\
\hline \multirow[t]{9}{*}{104} & $A$ & $a$ & 1.08 & 6.62 & 1.62 & 6.62 \\
\hline & & $\mathrm{b}$ & 1.74 & 6.34 & 1.62 & 5.43 \\
\hline & & C & 3.8 & 6.69 & 3.72 & 6.05 \\
\hline & LB & $a$ & 1.42 & 0 & 1.54 & 6.29 \\
\hline & & $b$ & 1.88 & 6.49 & 1.89 & 5.23 \\
\hline & & C & 4.13 & 6.72 & 3.79 & 6.41 \\
\hline & RB & $a$ & 1.38 & 6.43 & 1.09 & 5.04 \\
\hline & & $b$ & 2.08 & 6.98 & 2.31 & 4.27 \\
\hline & & C & 4.28 & 6.37 & 3.45 & 5.97 \\
\hline \multirow[t]{3}{*}{105} & $A$ & $a$ & $\begin{array}{l}1.49 \\
\end{array}$ & 0 & 1.4 & 5.42 \\
\hline & & $b$ & 2.08 & 5.3 & 1.46 & 5.48 \\
\hline & & C & 4.05 & 6.59 & 4.29 & 6.79 \\
\hline
\end{tabular}




\begin{tabular}{|c|c|c|c|c|c|c|}
\hline & LB & a & 0 & 0 & 0 & 0 \\
\hline & & $b$ & 2.3 & 0 & 0 & 0 \\
\hline & & C & 3.95 & 6.16 & 4.15 & 6.29 \\
\hline \multirow[t]{3}{*}{106} & A & $a$ & 1.43 & 5.36 & 1.83 & 6.1 \\
\hline & & $\mathrm{b}$ & 1.86 & 7.03 & 2.38 & 7.53 \\
\hline & & $\mathrm{C}$ & 4.31 & 6.41 & 4.54 & 7.85 \\
\hline \multirow[t]{9}{*}{107} & A & $a$ & 1.58 & 5.88 & 1.42 & 5.68 \\
\hline & & $b$ & 2.15 & 5.66 & 1.85 & 5.72 \\
\hline & & C & 3.94 & 5.67 & 4.2 & 5.72 \\
\hline & LB & $a$ & 1.37 & 0 & 1.03 & 0 \\
\hline & & $b$ & 2.4 & 5.68 & 2 & 0 \\
\hline & & $\mathrm{C}$ & 3.71 & 6.74 & 3.92 & 0 \\
\hline & RB & $\mathrm{a}$ & 1.6 & 6.87 & 1.42 & 6.2 \\
\hline & & $b$ & 2.04 & 6.09 & 1.98 & 5.91 \\
\hline & & C & 4 & 7.07 & 3.87 & 6.79 \\
\hline \multirow[t]{9}{*}{108} & A & $a$ & 1.3 & 5.1 & 1.39 & 4.23 \\
\hline & & $b$ & 1.86 & 4.45 & 1.19 & 4.55 \\
\hline & & C & 3.76 & 5.35 & 3.59 & 5.39 \\
\hline & LB & $a$ & 1.06 & 5.45 & 1.51 & 4.19 \\
\hline & & $b$ & 1.55 & 5.85 & 3.81 & 5.65 \\
\hline & & C & 3.94 & 6 & 0 & 0 \\
\hline & $\mathrm{RB}$ & $a$ & 1.93 & 0 & 1.45 & 3.63 \\
\hline & & $b$ & 1.37 & 0 & 1.69 & 3.5 \\
\hline & & $\mathrm{C}$ & 3.84 & 0 & 4.06 & 5.38 \\
\hline \multirow[t]{6}{*}{109} & A & $a$ & 1.87 & 0 & 1.9 & 4.86 \\
\hline & & $b$ & 2.44 & 0 & 2.23 & 4.81 \\
\hline & & $\mathrm{C}$ & 4.58 & 0 & 3.54 & 6.14 \\
\hline & RB & $a$ & 0 & 0 & 1.77 & 0 \\
\hline & & $b$ & 0 & 0 & 2.06 & 0 \\
\hline & & C & 0 & 0 & 3.78 & 7.61 \\
\hline \multirow[t]{9}{*}{110} & A & $a$ & 3.99 & 0 & 0 & 0 \\
\hline & & $b$ & 2.45 & 5.41 & 0 & 0 \\
\hline & & C & 3.99 & 6.05 & 3.74 & 5.17 \\
\hline & LB & $a$ & 1.37 & 0 & 0 & 0 \\
\hline & & $b$ & 3.46 & 0 & 0 & 0 \\
\hline & & C & 0 & 0 & 3.32 & 6.15 \\
\hline & $\mathrm{RB}$ & $a$ & 1.62 & 5.16 & 0 & 0 \\
\hline & & $b$ & 1.55 & 0 & 2.18 & 0 \\
\hline & & $\mathrm{C}$ & 3.53 & 5.45 & 3.77 & 0 \\
\hline \multirow[t]{6}{*}{111} & A & $\mathrm{a}$ & 1.73 & 6.55 & 1.52 & 6.55 \\
\hline & & b & 2.45 & 0 & 2.48 & 0 \\
\hline & & $\mathrm{C}$ & 3.57 & 6.14 & 3.95 & 6.69 \\
\hline & LB & $a$ & 1.7 & 5.85 & 0 & 0 \\
\hline & & $b$ & 2.99 & 6.2 & 0 & 0 \\
\hline & & C & 3.91 & 0 & 3.63 & 0 \\
\hline \multirow[t]{2}{*}{112} & A & $a$ & 1.45 & 0 & 1.38 & 4.11 \\
\hline & & b & 1.46 & 0 & 0 & 0 \\
\hline
\end{tabular}




\begin{tabular}{|c|c|c|c|c|c|c|}
\hline & & C & 4.16 & 5.64 & 3.95 & 4.68 \\
\hline & LB & $a$ & 0 & 0 & 0 & 0 \\
\hline & & $b$ & 0 & 0 & 0 & 0 \\
\hline & & $\mathrm{C}$ & 3.6 & 0 & 0 & 0 \\
\hline & $\mathrm{RB}$ & $a$ & 1.93 & 5.53 & 1.92 & 3.41 \\
\hline & & $b$ & 2.03 & 5.81 & 1.43 & 4.01 \\
\hline & & $\mathrm{C}$ & 3.52 & 0 & 2.99 & 6.38 \\
\hline \multirow[t]{6}{*}{113} & A & $a$ & 1.49 & 4.8 & 1.32 & 4.36 \\
\hline & & $b$ & 1.61 & 5.52 & 1.13 & 0 \\
\hline & & $\mathrm{C}$ & 3.61 & 6.04 & 3.37 & 5.31 \\
\hline & $\mathrm{RB}$ & $a$ & 1.59 & 6.57 & 1.51 & 4.22 \\
\hline & & $b$ & 2.4 & 7.06 & 0 & 0 \\
\hline & & $\mathrm{C}$ & 4.02 & 6.71 & 3.58 & 5.55 \\
\hline \multirow[t]{6}{*}{114} & LB & $a$ & 0 & 0 & 0 & 0 \\
\hline & & $b$ & 1.86 & 5.34 & 2 & 5.91 \\
\hline & & C & 3.92 & 5.22 & 0 & 0 \\
\hline & $\mathrm{RB}$ & $a$ & 0 & 0 & 0 & 0 \\
\hline & & $b$ & 2.6 & 5.45 & 2.19 & 4.73 \\
\hline & & $\mathrm{C}$ & 4.38 & 6.32 & 4.29 & 6.11 \\
\hline \multirow[t]{9}{*}{115} & A & $a$ & 1.66 & 5.3 & 1.24 & 4.77 \\
\hline & & $b$ & 1.91 & 5.89 & 2.03 & 0 \\
\hline & & $\mathrm{C}$ & 3.97 & 3.99 & 3.8 & 3.5 \\
\hline & LB & $a$ & 0 & 0 & 0 & 0 \\
\hline & & $\mathrm{b}$ & 0 & 0 & 0 & 0 \\
\hline & & $\mathrm{C}$ & 4.27 & 5.15 & 4.12 & 4.82 \\
\hline & $\mathrm{RB}$ & $a$ & 1.56 & 0 & 0 & 0 \\
\hline & & $b$ & 0 & 0 & 0 & 0 \\
\hline & & C & 3.47 & 0 & 3.29 & 0 \\
\hline \multirow[t]{3}{*}{116} & A & $a$ & 1.43 & 5.25 & 1.84 & 5.5 \\
\hline & & $b$ & 1.9 & 5.58 & 2.04 & 5.29 \\
\hline & & $C$ & 3.78 & 5.69 & 4.05 & 5.78 \\
\hline \multirow[t]{9}{*}{117} & A & $a$ & 1.6 & 6.74 & 1.19 & 5.8 \\
\hline & & $b$ & 1.74 & 6.01 & 1.43 & 5.01 \\
\hline & & $\mathrm{C}$ & 4.15 & 6.18 & 3.64 & 6.12 \\
\hline & LB & $a$ & 0 & 0 & 0 & 0 \\
\hline & & $b$ & 0 & 0 & 1.93 & 0 \\
\hline & & C & 4 & 5.16 & 0 & 0 \\
\hline & $\mathrm{RB}$ & a & 1.23 & 5.7 & 1.26 & 0 \\
\hline & & $b$ & 0 & 0 & 0 & 0 \\
\hline & & $\mathrm{C}$ & 0 & 0 & 0 & 0 \\
\hline \multirow[t]{3}{*}{118} & A & $a$ & 1.38 & 0 & 1.41 & 0 \\
\hline & & $b$ & 2.17 & 6.17 & 2.17 & 5.11 \\
\hline & & C & 4.13 & 0 & 4.06 & 5.15 \\
\hline \multirow[t]{4}{*}{119} & A & $a$ & 1.35 & 4.83 & 1.33 & 4.47 \\
\hline & & $b$ & 1.96 & 5.36 & 1.9 & 4.79 \\
\hline & & $\mathrm{C}$ & 4.3 & 4.29 & 3.64 & 4.21 \\
\hline & LB & $a$ & 0 & 0 & 0 & 0 \\
\hline
\end{tabular}




\begin{tabular}{|c|c|c|c|c|c|c|}
\hline & & $b$ & 1.8 & 5.64 & 0 & 0 \\
\hline & & $\mathrm{C}$ & 0 & 0 & 0 & 0 \\
\hline & RB & $a$ & 1.23 & 6.58 & 1.41 & 5.94 \\
\hline & & $b$ & 1.56 & 6.23 & 1.44 & 4.31 \\
\hline & & C & 4.15 & 7.07 & 3.83 & 4.95 \\
\hline \multirow[t]{3}{*}{120} & A & $a$ & 1.98 & 6.19 & 1.97 & 6.07 \\
\hline & & $b$ & 2.81 & 6.02 & 2.29 & 5.82 \\
\hline & & $\mathrm{C}$ & 4.16 & 5.63 & 4.03 & 5.92 \\
\hline \multirow[t]{6}{*}{121} & $A$ & $a$ & 1.11 & 0 & & \\
\hline & & $b$ & 2.61 & 0 & & \\
\hline & & C & 3.56 & 0 & & \\
\hline & LB & $a$ & 1.33 & 0 & 1.45 & 0 \\
\hline & & $b$ & 2.89 & 0 & 2.42 & 0 \\
\hline & & C & 3.53 & 0 & 3.66 & 0 \\
\hline \multirow[t]{6}{*}{122} & LB & $a$ & 1.67 & 6.36 & 1.82 & 5.7 \\
\hline & & $b$ & 1.82 & 6.11 & 2.35 & 6.33 \\
\hline & & C & 4.09 & 6.31 & 3.98 & 6.06 \\
\hline & $\mathrm{RB}$ & $a$ & 1.54 & 6.12 & 1.33 & 5.9 \\
\hline & & $b$ & 1.95 & 6 & 1.87 & 5.09 \\
\hline & & C & 3.93 & 5.74 & 3.87 & 5.77 \\
\hline \multirow[t]{9}{*}{123} & A & a & 1.63 & 5.51 & 1.09 & 6.09 \\
\hline & & $b$ & 2.11 & 5.59 & 2.26 & 5.95 \\
\hline & & $\mathrm{C}$ & 4.04 & 6.6 & 4.17 & 6.55 \\
\hline & LB & $a$ & 1.74 & 5.82 & 1.56 & 5.6 \\
\hline & & $b$ & 2.63 & 6.58 & 2.4 & 6.39 \\
\hline & & $C$ & 4.24 & 6.82 & 3.56 & 5.2 \\
\hline & RB & $a$ & 1.26 & 5.59 & 1.24 & 5.99 \\
\hline & & $b$ & 2 & 6.4 & 1.98 & 5.51 \\
\hline & & $\mathrm{C}$ & 4.25 & 6.28 & 4.12 & 6.6 \\
\hline \multirow[t]{3}{*}{124} & A & $a$ & 1.54 & 5.62 & 1.14 & 5.49 \\
\hline & & $b$ & 2.16 & 5.59 & 2.84 & 5.52 \\
\hline & & C & 4.04 & 6.44 & 4.13 & 5.77 \\
\hline \multirow[t]{6}{*}{125} & A & $a$ & 1.44 & 6.53 & 1.42 & 5.94 \\
\hline & & $b$ & 2 & 5.51 & 1.9 & 5.89 \\
\hline & & C & 3.56 & 6.52 & 3.57 & 6.29 \\
\hline & LB & $a$ & 1.33 & 5.48 & 1.65 & 5.55 \\
\hline & & $b$ & 2.17 & 6.17 & 2.62 & 6.02 \\
\hline & & $\mathrm{C}$ & 3.96 & 6.19 & 3.9 & 6.13 \\
\hline \multirow[t]{6}{*}{126} & $A$ & $a$ & 1.52 & 5.94 & 1.34 & 5.95 \\
\hline & & $b$ & 2.54 & 6.26 & 2.25 & 6.38 \\
\hline & & $\mathrm{C}$ & 4.37 & 6.66 & 3.95 & 6.76 \\
\hline & RB & $a$ & 1.51 & 6.85 & 1.6 & 6.33 \\
\hline & & $b$ & 2.17 & 6.55 & 2.04 & 6.51 \\
\hline & & C & 3.74 & 6.7 & 3.84 & 6.69 \\
\hline \multirow[t]{3}{*}{127} & A & $\mathrm{a}$ & 1.38 & 5.5 & 1.27 & 5.36 \\
\hline & & $b$ & 1.91 & 5.77 & 1.57 & 5.67 \\
\hline & & C & 3.88 & 6.71 & 4.06 & 6.81 \\
\hline
\end{tabular}




\begin{tabular}{|c|c|c|c|c|c|c|}
\hline & LB & $\mathrm{a}$ & 1.8 & 5.75 & 1.32 & 5.99 \\
\hline & & $b$ & 2.23 & 5.99 & 2.17 & 5.85 \\
\hline & & C & 4 & 5.78 & 4.02 & 6.02 \\
\hline \multirow[t]{6}{*}{128} & A & $a$ & 1.58 & 6.75 & 1.5 & 6.24 \\
\hline & & $b$ & 2.08 & 0 & 2.31 & 0 \\
\hline & & C & 4.37 & 6.88 & 4.19 & 6.26 \\
\hline & LB & $a$ & 1.4 & 5.84 & 1.32 & 5.85 \\
\hline & & $b$ & 2.4 & 0 & 2.25 & 0 \\
\hline & & C & 4.04 & 6.41 & 4.15 & 6.48 \\
\hline \multirow[t]{6}{*}{129} & A & $a$ & 1.53 & 6.62 & 1.56 & 5.83 \\
\hline & & $b$ & 2.3 & 5.9 & 2.06 & 5.71 \\
\hline & & $\mathrm{C}$ & 3.95 & 5.7 & 4.33 & 5.93 \\
\hline & $\mathrm{RB}$ & $\mathrm{a}$ & 1.62 & 6.27 & 1.83 & 6.37 \\
\hline & & $b$ & 2.33 & 6.58 & 2.24 & 6.69 \\
\hline & & C & 4.25 & 6.26 & 4.44 & 6.26 \\
\hline \multirow[t]{3}{*}{130} & A & $a$ & 1.59 & 5.68 & 1.53 & 5.37 \\
\hline & & $b$ & 2.38 & 5.71 & 2.41 & 6.08 \\
\hline & & C & 3.89 & 6.27 & 4.11 & 6.17 \\
\hline \multirow[t]{3}{*}{131} & A & $a$ & 1.64 & 5.97 & 1.59 & 5.65 \\
\hline & & $b$ & 2.14 & 6.02 & 2.35 & 5.65 \\
\hline & & C & 3.95 & 6.03 & 3.69 & 5.97 \\
\hline \multirow[t]{6}{*}{132} & A & $a$ & 1.62 & 6.36 & 1.6 & 5.84 \\
\hline & & $b$ & 2.35 & 6.5 & 2.23 & 6.22 \\
\hline & & $\mathrm{C}$ & 4.35 & 6.46 & 4.28 & 6.26 \\
\hline & RB & $a$ & 1.43 & 6.21 & 1.6 & 6.24 \\
\hline & & $b$ & 2.06 & 6.38 & 2.14 & 6.35 \\
\hline & & C & 4.27 & 6.16 & 4.24 & 6.07 \\
\hline \multirow[t]{3}{*}{133} & A & $a$ & 1.38 & 6.5 & 1.45 & 5.69 \\
\hline & & $b$ & 2.03 & 6.46 & 2.09 & 6.1 \\
\hline & & C & 4.2 & 5.68 & 4.09 & 5.8 \\
\hline \multirow[t]{3}{*}{134} & A & $a$ & 1.52 & 6.36 & 1.57 & 5.93 \\
\hline & & $b$ & 2.17 & 6.06 & 2.28 & 6.27 \\
\hline & & C & 4.07 & 6.12 & 4.26 & 6.45 \\
\hline \multirow[t]{9}{*}{135} & A & $a$ & 1.47 & 6 & 1.57 & 6.02 \\
\hline & & $b$ & 2.07 & 6.23 & 2.42 & 5.87 \\
\hline & & C & 3.9 & 6.72 & 4.14 & 6.45 \\
\hline & LB & $a$ & 1.51 & 5.94 & 1.69 & 6.44 \\
\hline & & $b$ & 2.42 & 5.74 & 2.41 & 6.1 \\
\hline & & $\mathrm{C}$ & 4.17 & 6.73 & 3.95 & 6.16 \\
\hline & RB & $a$ & 1.65 & 6.09 & 1.69 & 6.18 \\
\hline & & $b$ & 2.41 & 6.53 & 2.19 & 5.84 \\
\hline & & $\mathrm{C}$ & 4.23 & 6.27 & 3.77 & 6.31 \\
\hline \multirow[t]{5}{*}{136} & A & $a$ & 1.41 & 6.39 & 1.42 & 5.81 \\
\hline & & $b$ & 2.47 & 6.71 & 2.26 & 6.16 \\
\hline & & C & 4.04 & 6.67 & 3.89 & 6.05 \\
\hline & LB & $a$ & 1.58 & 6.79 & 1.73 & 5.85 \\
\hline & & $b$ & 1.98 & 5.94 & 1.94 & 6.71 \\
\hline
\end{tabular}




\begin{tabular}{|r|r|r|r|r|r|r|} 
& & C & 4.06 & 6.47 & 4.09 & 6.41 \\
\hline & RB & a & 1.47 & 6.43 & 1.72 & 6.24 \\
\hline & & b & 2.09 & 6.45 & 2.29 & 5.95 \\
\hline & & $\mathrm{c}$ & 4.1 & 6.59 & 4.38 & 6.1 \\
\hline & $\mathrm{A}$ & $\mathrm{a}$ & 1.59 & 6.13 & 1.53 & 6.05 \\
\hline & & $\mathrm{b}$ & 1.96 & 6.59 & 1.89 & 5.83 \\
\hline & & $\mathrm{c}$ & 3.91 & 6.45 & 3.72 & 5.97 \\
\hline & $\mathrm{A}$ & $\mathrm{a}$ & 1.4 & 5.67 & 1.3 & 5.74 \\
\hline & & $\mathrm{b}$ & 2.14 & 5.85 & 2.17 & 5.49 \\
\hline & & $\mathrm{C}$ & 4.31 & 6.28 & 3.7 & 5.85 \\
\hline & $\mathrm{A}$ & $\mathrm{a}$ & 1.42 & 5.56 & 1.41 & 5.46 \\
\hline & & $\mathrm{b}$ & 1.92 & 5.71 & 2.11 & 5.39 \\
\hline & & $\mathrm{C}$ & 3.74 & 6.37 & 3.78 & 6.2 \\
\hline & $\mathrm{RB}$ & $\mathrm{a}$ & 1.61 & 6.61 & 1.41 & 6.34 \\
\hline & & $\mathrm{b}$ & 2.21 & 6.6 & 2.25 & 6.54 \\
\hline & & $\mathrm{c}$ & 4.18 & 6.84 & 4.08 & 6.81 \\
\hline & $\mathrm{A}$ & $\mathrm{a}$ & 1.35 & 6.31 & 1.39 & 6.14 \\
\hline & & $\mathrm{b}$ & 2.11 & 6.23 & 2.31 & 6.18 \\
\hline & & $\mathrm{c}$ & 4 & 6.07 & 4.2 & 6.64 \\
\hline
\end{tabular}

\begin{tabular}{|c|c|c|c|c|c|c|}
\hline \multicolumn{7}{|c|}{ Intracortical Simulated Defects : 18 impulses 90 degrees } \\
\hline \multirow[b]{2}{*}{ Mandible \# } & \multirow[b]{2}{*}{ Area } & \multirow[b]{2}{*}{ Defect ID } & \multicolumn{2}{|c|}{ Conventional } & \multicolumn{2}{|c|}{ Renderings } \\
\hline & & & width & length & width & length \\
\hline \multirow[t]{9}{*}{101} & $A$ & $a$ & 0.92 & 4.83 & 1.04 & 4.66 \\
\hline & & $\mathrm{b}$ & 1.77 & 5.43 & 6.45 & 1.83 \\
\hline & & $\mathrm{c}$ & 3.88 & 5.76 & 4.34 & 5.83 \\
\hline & LB & $a$ & 1.01 & 5.5 & 1.06 & 4.66 \\
\hline & & $b$ & 1.91 & 5.97 & 1.98 & 4.43 \\
\hline & & $\mathrm{c}$ & 5.79 & 5.94 & 3.45 & 5.93 \\
\hline & $\mathrm{RB}$ & $\mathrm{a}$ & 1.29 & 6.68 & 1.47 & 2.9 \\
\hline & & $b$ & 1.68 & 5.33 & 1.74 & 1.74 \\
\hline & & $\mathrm{c}$ & 3.91 & 6.01 & 4.02 & 6.27 \\
\hline \multirow[t]{9}{*}{102} & A & $\mathrm{a}$ & 0 & 0 & 0 & 0 \\
\hline & & $\mathrm{b}$ & 0 & 0 & 0 & 0 \\
\hline & & $\mathrm{c}$ & 3.79 & 6.34 & 3.83 & 6.4 \\
\hline & LB & $a$ & 0 & 0 & 1.35 & 3.64 \\
\hline & & $\mathrm{b}$ & 0 & 0 & 0 & 0 \\
\hline & & $\mathrm{C}$ & 3.45 & 5.91 & 3.86 & 6.16 \\
\hline & RB & $a$ & 0 & 0 & 0 & 0 \\
\hline & & $\mathrm{b}$ & 0 & 0 & 0 & 0 \\
\hline & & $\mathrm{c}$ & 0 & 0 & 0 & 0 \\
\hline \multirow[t]{4}{*}{103} & A & $a$ & 1.28 & 5.47 & 1.17 & 4.07 \\
\hline & & $b$ & 2.34 & 6.6 & 2.64 & 4.17 \\
\hline & & $\mathrm{c}$ & 3.8 & 7.21 & 4.35 & 5.39 \\
\hline & LB & $a$ & 0 & 0 & 0 & 0 \\
\hline
\end{tabular}




\begin{tabular}{|c|c|c|c|c|c|c|}
\hline & & $b$ & 0 & 0 & 2.43 & 5.31 \\
\hline & & $\mathrm{C}$ & 0 & 0 & 0 & 0 \\
\hline & RB & $a$ & 1.05 & 6.39 & 0 & 0 \\
\hline & & $b$ & 2.45 & 0 & 2.12 & 4.7 \\
\hline & & C & 4.09 & 0 & 4.13 & 5.66 \\
\hline \multirow[t]{9}{*}{104} & A & $a$ & 1.09 & 6.42 & 0.81 & 6.15 \\
\hline & & $b$ & 1.53 & 5.79 & 1.68 & 4.74 \\
\hline & & $\mathrm{C}$ & 3.93 & 6.05 & 3.86 & 5.94 \\
\hline & LB & $\mathrm{a}$ & 1.5 & 0 & 1.64 & 5.86 \\
\hline & & $b$ & 1.78 & 6.24 & 1.94 & 6.22 \\
\hline & & C & 3.73 & 6.91 & 4.17 & 6.87 \\
\hline & RB & $a$ & 1.37 & 6.17 & 1.23 & 5.81 \\
\hline & & $b$ & 2.15 & 7.02 & 2.27 & 4.18 \\
\hline & & C & 3.86 & 6.28 & 3.91 & 6.12 \\
\hline \multirow[t]{6}{*}{105} & A & $\mathrm{a}$ & 1.44 & 0 & 1.36 & 5.78 \\
\hline & & $b$ & 1.84 & 5.36 & 1.51 & 5.22 \\
\hline & & $\mathrm{C}$ & 4.01 & 6.91 & 4.25 & 6.9 \\
\hline & LB & $a$ & 0 & 0 & 0 & 0 \\
\hline & & $b$ & 2.45 & 0 & 0 & 0 \\
\hline & & C & 3.82 & 6.07 & 3.99 & 6.09 \\
\hline \multirow[t]{3}{*}{106} & A & $\mathrm{a}$ & 1.39 & 5.68 & 1.77 & 6.66 \\
\hline & & $b$ & 1.84 & 6.86 & 2.37 & 7.99 \\
\hline & & C & 3.74 & 6.74 & 4.86 & 8.08 \\
\hline \multirow[t]{9}{*}{107} & A & $a$ & 1.42 & 6.17 & 1.52 & 5.5 \\
\hline & & $b$ & 2.22 & 5.61 & 2.14 & 5.4 \\
\hline & & C & 4.05 & 5.86 & 4.22 & 5.58 \\
\hline & LB & a & 1.53 & 0 & 1.18 & 0 \\
\hline & & $b$ & 2.19 & 5.87 & 1.87 & 0 \\
\hline & & C & 3.64 & 6.46 & 3.5 & 0 \\
\hline & $\mathrm{RB}$ & $a$ & 1.35 & 6.7 & 1.6 & 5.64 \\
\hline & & $b$ & 2.09 & 6.38 & 2.39 & 6.24 \\
\hline & & $\mathrm{C}$ & 4.17 & 6.78 & 4.15 & 6.58 \\
\hline \multirow[t]{9}{*}{108} & A & a & 1.35 & 4.92 & 1.33 & 5.32 \\
\hline & & $b$ & 1.9 & 5.46 & 1.33 & 0 \\
\hline & & $\mathrm{C}$ & 3.81 & 5.45 & 3.65 & 5.38 \\
\hline & LB & $\mathrm{a}$ & 1.37 & 5.99 & 1.45 & 4.17 \\
\hline & & $b$ & 1.93 & 5.87 & 3.65 & 5.53 \\
\hline & & C & 3.82 & 5.65 & 0 & 0 \\
\hline & RB & $a$ & 1.46 & 0 & 1.18 & 2.74 \\
\hline & & $b$ & 1.48 & 0 & 1.62 & 5.07 \\
\hline & & $\mathrm{C}$ & 3.85 & 0 & 3.92 & 5.03 \\
\hline \multirow[t]{6}{*}{109} & A & $a$ & 1.42 & 0 & 2.15 & 5.18 \\
\hline & & $b$ & 2.33 & 0 & 2.21 & 4.86 \\
\hline & & C & 3.46 & 0 & 2.83 & 6.17 \\
\hline & RB & $\mathrm{a}$ & 0 & 0 & 1.61 & 0 \\
\hline & & $b$ & 0 & 0 & 2.32 & 0 \\
\hline & & C & 0 & 0 & 3.85 & 7.65 \\
\hline
\end{tabular}




\begin{tabular}{|c|c|c|c|c|c|c|}
\hline \multirow[t]{9}{*}{110} & A & $a$ & 0 & 0 & 0 & 0 \\
\hline & & $b$ & 2.46 & 5.72 & 0 & 0 \\
\hline & & $\mathrm{C}$ & 4.03 & 6.06 & 3.92 & 4.99 \\
\hline & LB & $a$ & 0 & 0 & 0 & 0 \\
\hline & & $b$ & 0 & 0 & 0 & 0 \\
\hline & & $\mathrm{C}$ & 0 & 0 & 3.21 & 6.31 \\
\hline & RB & $a$ & 1.34 & 5.48 & 0 & 0 \\
\hline & & $b$ & 1.78 & 0 & 2.01 & 0 \\
\hline & & C & 3.27 & 5.46 & 3.7 & 0 \\
\hline \multirow[t]{6}{*}{111} & A & $a$ & 1.64 & 6.7 & 1.66 & 7.11 \\
\hline & & $b$ & 2.51 & 0 & 2.81 & 0 \\
\hline & & C & 3.83 & 6.44 & 3.89 & 6.82 \\
\hline & LB & $a$ & 1.6 & 5.42 & 0 & 0 \\
\hline & & $b$ & 2.32 & 0 & 0 & 0 \\
\hline & & $\mathrm{C}$ & 4.02 & 0 & 3.92 & 0 \\
\hline \multirow[t]{9}{*}{112} & A & $a$ & 1.26 & 0 & 1.36 & 4.07 \\
\hline & & $b$ & 1.48 & 0 & 0 & 0 \\
\hline & & $\mathrm{C}$ & 3.82 & 5.45 & 3.9 & 4.67 \\
\hline & LB & $a$ & 1.72 & 0 & 0 & 0 \\
\hline & & b & 0 & 0 & 0 & 0 \\
\hline & & $\mathrm{C}$ & 4.46 & 0 & 0 & 0 \\
\hline & RB & $a$ & 1.12 & 5.5 & 1.64 & 3.65 \\
\hline & & $b$ & 2.66 & 5.85 & 1.86 & 3.91 \\
\hline & & C & 3.92 & 0 & 2.3 & 6.39 \\
\hline \multirow[t]{6}{*}{113} & A & $a$ & 1.41 & 5.01 & 1.3 & 4.51 \\
\hline & & $b$ & 1.72 & 5.67 & 1.28 & 0 \\
\hline & & C & 3.83 & 6.31 & 3.47 & 5.27 \\
\hline & RB & a & 0 & 0 & 0 & 0 \\
\hline & & $b$ & 1.78 & 6.64 & 1.9 & 5.21 \\
\hline & & $\mathrm{C}$ & 4.03 & 6.44 & 5.68 & 5.61 \\
\hline \multirow[t]{6}{*}{114} & LB & $\mathrm{a}$ & $\begin{array}{l}1.7 \\
\end{array}$ & 5.86 & 0 & 0 \\
\hline & & $b$ & 1.98 & 6.5 & 1.87 & 5.16 \\
\hline & & $\mathrm{C}$ & 3.48 & 5.32 & 2.04 & 4.92 \\
\hline & RB & $a$ & 0 & 0 & 0 & 0 \\
\hline & & $b$ & 0 & 0 & 4.15 & 4.53 \\
\hline & & C & 4.42 & 6.32 & 2.24 & 5.86 \\
\hline \multirow[t]{9}{*}{115} & A & $a$ & 1.41 & 5.87 & 1.37 & 4.96 \\
\hline & & $b$ & 1.85 & 6.22 & 1.68 & 0 \\
\hline & & $\mathrm{C}$ & 4.02 & 3.83 & 3.81 & 3.31 \\
\hline & LB & $a$ & 0 & 0 & 0 & 0 \\
\hline & & $\mathrm{b}$ & 0 & 0 & 0 & 0 \\
\hline & & C & 4.16 & 4.95 & 3.7 & 4.97 \\
\hline & RB & $a$ & 0 & 0 & 0 & 0 \\
\hline & & b & 1.96 & 0 & 1.98 & 0 \\
\hline & & $\mathrm{C}$ & 3.24 & 0 & 3.58 & 0 \\
\hline \multirow[t]{2}{*}{116} & A & $\mathrm{a}$ & 1.56 & 5.87 & 1.49 & 5.06 \\
\hline & & b & 1.96 & 5.85 & 1.26 & 5.01 \\
\hline
\end{tabular}




\begin{tabular}{|c|c|c|c|c|c|c|}
\hline & & C & 4.08 & 5.77 & 3.77 & 5.5 \\
\hline \multirow[t]{9}{*}{117} & A & $a$ & 1.38 & 6.06 & 1.53 & 5.77 \\
\hline & & $b$ & 1.38 & 6.45 & 1.53 & 5.99 \\
\hline & & $\mathrm{C}$ & 4.4 & 6.47 & 4.15 & 6.07 \\
\hline & LB & $a$ & 0 & 0 & 0 & 0 \\
\hline & & $b$ & 2.69 & 0 & 1.73 & 0 \\
\hline & & $\mathrm{C}$ & 3.86 & 4.66 & 0 & 0 \\
\hline & RB & $a$ & 1.28 & 5.57 & 1.48 & 0 \\
\hline & & $b$ & 0 & 0 & 0 & 0 \\
\hline & & $\mathrm{C}$ & 3.64 & 5.98 & 2.29 & 0 \\
\hline \multirow[t]{3}{*}{118} & A & $a$ & 1.68 & 0 & 1.73 & 0 \\
\hline & & $b$ & 2.12 & 6.26 & 1.48 & 5.17 \\
\hline & & $\mathrm{C}$ & 4.03 & 0 & 3.73 & 5.19 \\
\hline \multirow[t]{9}{*}{119} & A & $a$ & 1.26 & 4.69 & 1.71 & 4.39 \\
\hline & & $b$ & 1.93 & 5.01 & 1.86 & 4.62 \\
\hline & & $C$ & 4.06 & 4.06 & 3.86 & 4.21 \\
\hline & LB & $\mathrm{a}$ & 1.26 & 4.83 & 0 & 0 \\
\hline & & $b$ & 1.83 & 5.54 & 0 & 0 \\
\hline & & C & 0 & 0 & 0 & 0 \\
\hline & $\mathrm{RB}$ & $a$ & 1.18 & 6.05 & 1.28 & 4.48 \\
\hline & & $b$ & 2.02 & 5.87 & 1.65 & 5.73 \\
\hline & & $\mathrm{C}$ & 4.24 & 6.87 & 3.81 & 4.77 \\
\hline \multirow[t]{3}{*}{120} & A & $a$ & 1.77 & 6.21 & 2.02 & 5.65 \\
\hline & & $b$ & 2.77 & 6.09 & 2.43 & 5.49 \\
\hline & & $\mathrm{C}$ & 4.15 & 5.22 & 3.8 & 5.63 \\
\hline \multirow[t]{6}{*}{121} & A & $a$ & 1.2 & 0 & 1.65 & 7.06 \\
\hline & & $b$ & 1.91 & 0 & 2.13 & 6.5 \\
\hline & & C & 3.65 & 0 & 3.35 & 6.25 \\
\hline & LB & $a$ & 1.42 & 0 & 1.44 & 0 \\
\hline & & $b$ & 2.4 & 0 & 2.28 & 0 \\
\hline & & $\mathrm{C}$ & 3.15 & 0 & 3.94 & 0 \\
\hline \multirow[t]{6}{*}{122} & LB & $a$ & 1.52 & 5.97 & 1.36 & 5.79 \\
\hline & & $b$ & 2.03 & 6.17 & 2.61 & 6.14 \\
\hline & & $\mathrm{C}$ & 4.04 & 6.26 & 4.05 & 5.73 \\
\hline & RB & $a$ & 1.37 & 5.8 & 1.49 & 5.66 \\
\hline & & $b$ & 1.89 & 5.79 & 1.99 & 5.71 \\
\hline & & C & 4.34 & 6.25 & 3.97 & 5.65 \\
\hline \multirow[t]{9}{*}{123} & A & a & 1.22 & 6.23 & 1.28 & 5.97 \\
\hline & & $b$ & 2.09 & 6.23 & 2.33 & 6.41 \\
\hline & & $\mathrm{C}$ & 3.67 & 6.38 & 4.2 & 6.59 \\
\hline & LB & $a$ & 1.71 & 5.87 & 1.21 & 5.75 \\
\hline & & $b$ & 2.57 & 6.73 & 2.21 & 6.76 \\
\hline & & C & 4.07 & 6.36 & 3.48 & 5.62 \\
\hline & RB & $a$ & 1.66 & 6.22 & 1.47 & 5.38 \\
\hline & & $b$ & 2.16 & 6.13 & 1.63 & 5.99 \\
\hline & & $C$ & 4.32 & 6.63 & 3.97 & 6.36 \\
\hline 124 & A & $\mathrm{a}$ & 1.57 & 5.57 & 1.51 & 5.58 \\
\hline
\end{tabular}




\begin{tabular}{|c|c|c|c|c|c|c|}
\hline & & b & 2.27 & 5.69 & 2.23 & 5.85 \\
\hline & & $\mathrm{C}$ & 4.15 & 6.17 & 3.87 & 5.89 \\
\hline \multirow[t]{6}{*}{125} & A & a & 1.31 & 5.78 & 1.46 & 5.74 \\
\hline & & b & 2.11 & 5.64 & 2.13 & 5.38 \\
\hline & & $\mathrm{C}$ & 4.17 & 6.07 & 3.36 & 6.1 \\
\hline & LB & $a$ & 1.31 & 5.29 & 1.79 & 6.47 \\
\hline & & $b$ & 1.92 & 6.05 & 2.81 & 6 \\
\hline & & C & 3.8 & 5.89 & 3.94 & 6.9 \\
\hline \multirow[t]{6}{*}{126} & A & $a$ & 1.33 & 6.49 & 1.4 & 5.59 \\
\hline & & $b$ & 1.97 & 5.83 & 2.41 & 6.21 \\
\hline & & C & 4.44 & 6.84 & 4.23 & 6.9 \\
\hline & RB & a & 1.31 & 6.78 & 1.56 & 6.71 \\
\hline & & $b$ & 2.17 & 6.42 & 2.47 & 7.02 \\
\hline & & C & 4.16 & 6.71 & 4.4 & 6.6 \\
\hline \multirow[t]{6}{*}{127} & A & $a$ & 1.4 & 5.74 & 1.31 & 5.47 \\
\hline & & b & 2.08 & 6.46 & 1.79 & 5.99 \\
\hline & & C & 4 & 7.25 & 3.93 & 6.68 \\
\hline & LB & $a$ & 1.73 & 5.5 & 1.37 & 6 \\
\hline & & $b$ & 2.13 & 5.83 & 2.25 & 6.01 \\
\hline & & c & 3.83 & 5.93 & 3.87 & 6.54 \\
\hline \multirow[t]{6}{*}{128} & A & $a$ & 1.86 & 6.53 & 1.48 & 6.69 \\
\hline & & $b$ & 2.15 & 0 & 2.4 & 0 \\
\hline & & C & 4.34 & 7.04 & 4.26 & 6.06 \\
\hline & LB & a & 1.62 & 5.9 & 1.34 & 5.78 \\
\hline & & $\mathrm{b}$ & 2.24 & 0 & 2.41 & 0 \\
\hline & & 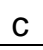 & 4.45 & 6.02 & 4.21 & 5.85 \\
\hline \multirow[t]{6}{*}{129} & A & a & 1.39 & 5.99 & 1.83 & 5.27 \\
\hline & & b & 2.35 & 5.66 & 2.22 & 5.91 \\
\hline & & $\mathrm{C}$ & 4.22 & 6.02 & 4.06 & 5.4 \\
\hline & RB & $a$ & 1.64 & 6.37 & 1.85 & 6.33 \\
\hline & & $b$ & 2.51 & 6.14 & 2.48 & 6.48 \\
\hline & & $\mathrm{C}$ & 4.31 & 6.46 & 4.24 & 6.12 \\
\hline \multirow[t]{3}{*}{130} & A & $a$ & 1.42 & 5.52 & 1.41 & 5.52 \\
\hline & & $b$ & 2.2 & 5.8 & 2.24 & 5.94 \\
\hline & & C & 3.93 & 6.16 & 4.01 & 6.09 \\
\hline \multirow[t]{3}{*}{131} & A & a & 1.45 & 5.42 & 1.48 & 5.72 \\
\hline & & $b$ & 2.13 & 5.86 & 2.24 & 6.28 \\
\hline & & C & 3.9 & 6.24 & 3.75 & 6.1 \\
\hline \multirow[t]{6}{*}{132} & A & a & 1.71 & 6.32 & 0 & 0 \\
\hline & & $b$ & 2.42 & 6.77 & 2.51 & 5.85 \\
\hline & & $\mathrm{C}$ & 4.13 & 6.46 & 4.18 & 6.04 \\
\hline & RB & a & 1.49 & 6.11 & 1.65 & 5.89 \\
\hline & & $b$ & 2.12 & 6.3 & 2.41 & 6.24 \\
\hline & & C & 4.35 & 6.14 & 4.18 & 6.13 \\
\hline \multirow[t]{3}{*}{133} & A & $a$ & 1.42 & 6.41 & 1.34 & 5.98 \\
\hline & & $b$ & 1.96 & 6.14 & 1.89 & 6.21 \\
\hline & & C & 4.09 & 5.5 & 4.13 & 5.4 \\
\hline
\end{tabular}




\begin{tabular}{|c|c|c|c|c|c|c|}
\hline 134 & A & a & 1.41 & 6.5 & 1.7 & 6.04 \\
\hline & & $b$ & 2.35 & 6.07 & 2.3 & 6.16 \\
\hline & & C & 3.96 & 6.32 & 3.95 & 5.51 \\
\hline \multirow[t]{9}{*}{135} & A & a & 1.51 & 6.23 & 1.49 & 6.16 \\
\hline & & $b$ & 2.2 & 6.13 & 2.1 & 5.69 \\
\hline & & C & 4.16 & 6.35 & 4.09 & 6.45 \\
\hline & LB & $a$ & 1.55 & 5.88 & 1.54 & 6.26 \\
\hline & & $b$ & 2.24 & 6.14 & 2.35 & 6.39 \\
\hline & & $\mathrm{C}$ & 4.11 & 6.53 & 3.97 & 6.43 \\
\hline & RB & $a$ & 1.47 & 6.3 & 1.52 & 6.28 \\
\hline & & $b$ & 2.19 & 6.07 & 2.18 & 5.87 \\
\hline & & $C$ & 4.17 & 6.52 & 3.71 & 6.12 \\
\hline \multirow[t]{9}{*}{136} & A & $a$ & 1.65 & 6.38 & 1.48 & 5.97 \\
\hline & & $b$ & 2.08 & 6.69 & 2.27 & 6.13 \\
\hline & & $C$ & 4.21 & 6.15 & 3.72 & 5.84 \\
\hline & LB & $a$ & 4.54 & 6.51 & 1.47 & 5.98 \\
\hline & & $b$ & 2.07 & 5.88 & 1.96 & 6.21 \\
\hline & & C & 4.08 & 6.73 & 4.16 & 6.59 \\
\hline & RB & $a$ & 1.46 & 6.29 & 1.55 & 6.14 \\
\hline & & b & 2.03 & 6.41 & 25.36 & 6.01 \\
\hline & & C & 4.08 & 6.68 & 4.24 & 6.41 \\
\hline \multirow[t]{3}{*}{137} & A & $a$ & 1.59 & 5.79 & 1.73 & 5.56 \\
\hline & & $b$ & 1.91 & 6.68 & 1.92 & 5.61 \\
\hline & & $\mathrm{C}$ & 3.54 & 6.15 & 3.82 & 6.17 \\
\hline \multirow[t]{3}{*}{138} & A & $a$ & 1.51 & 5.73 & 1.36 & 5.71 \\
\hline & & $b$ & 2.15 & 5.24 & 2.04 & 5.67 \\
\hline & & $C$ & 4.21 & 6.11 & 3.91 & 5.98 \\
\hline \multirow[t]{6}{*}{139} & A & a & 1.34 & 5.76 & 1.56 & 5.56 \\
\hline & & $b$ & 2.05 & 5.62 & 2.34 & 5.43 \\
\hline & & $C$ & 3.98 & 6.36 & 3.79 & 6.13 \\
\hline & $\mathrm{RB}$ & a & 1.35 & 6.3 & 1.48 & 6.3 \\
\hline & & $b$ & 1.98 & 6.88 & 2.22 & 6.36 \\
\hline & & C & 4.18 & 6.77 & 4.12 & 6.65 \\
\hline \multirow[t]{3}{*}{140} & A & $a$ & 1.46 & 6.41 & 1.25 & 5.85 \\
\hline & & $b$ & 2.17 & 6.11 & 2.17 & 6.32 \\
\hline & & C & 4.21 & 5.93 & 3.79 & 6.21 \\
\hline
\end{tabular}




\section{APPENDIX F \\ STATISTICAL ANALYSIS - EDENTULOUS MANDIBLE PROJECT}


12 Impulses, 90 Degrees - Diameter

Diameter(12\#11.jmp: Fit $Y$ by $X$

Page 3 of 6

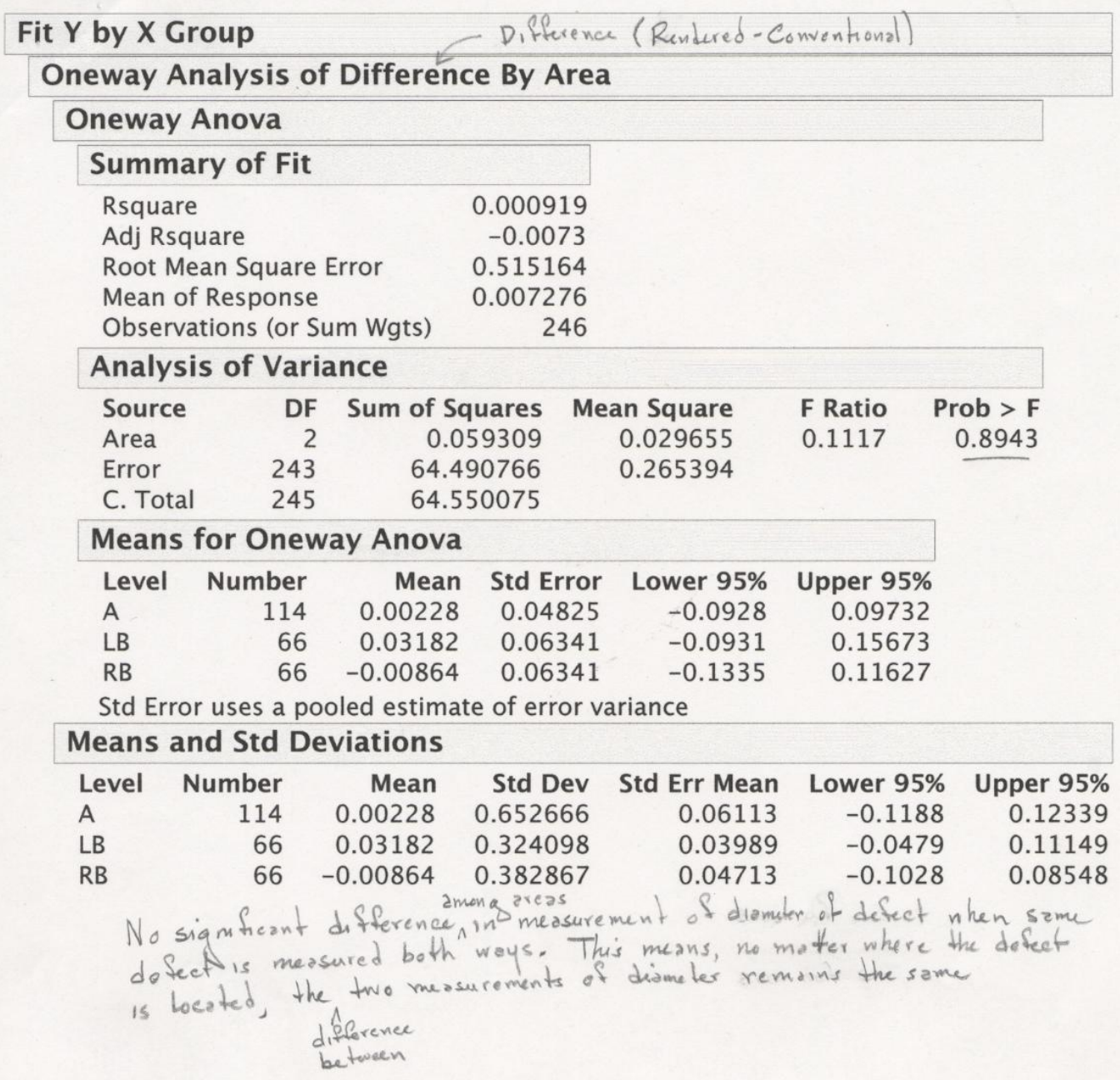


12 Impulses, 90 Degrees - Diameter

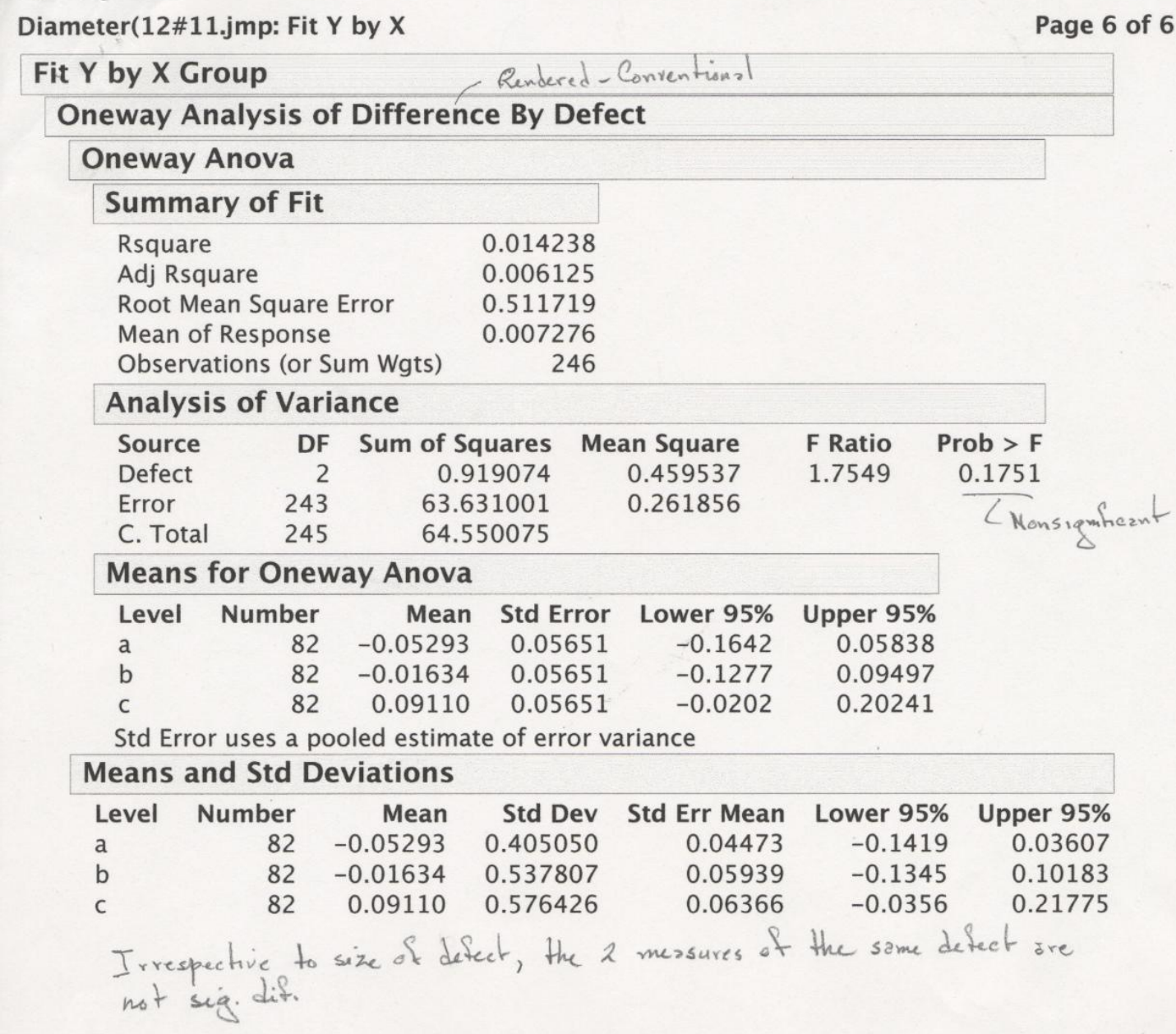


12 Impulses, 90 Degrees - Width and Length

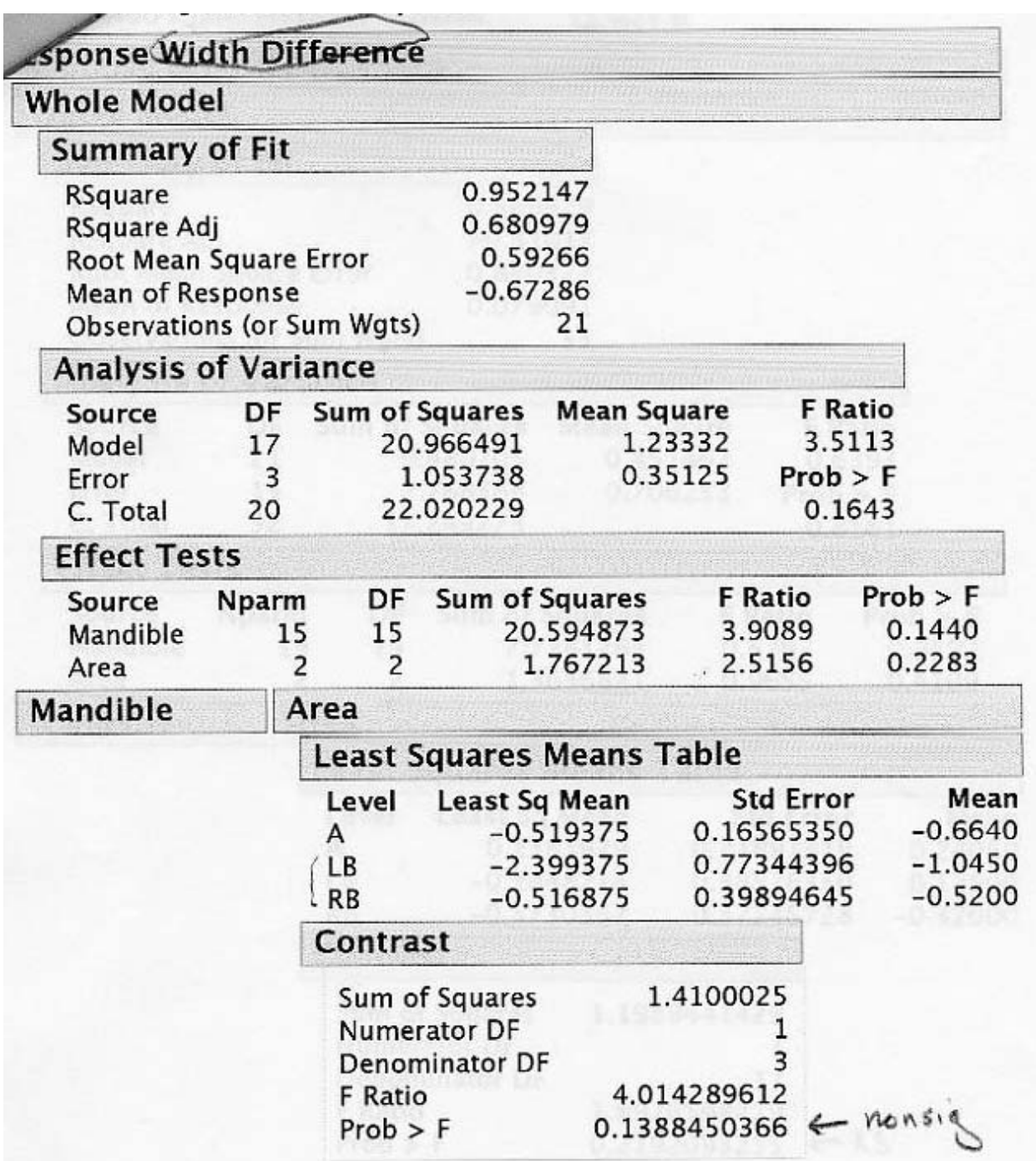


12 Impulses, 90 Degrees - Width and Length

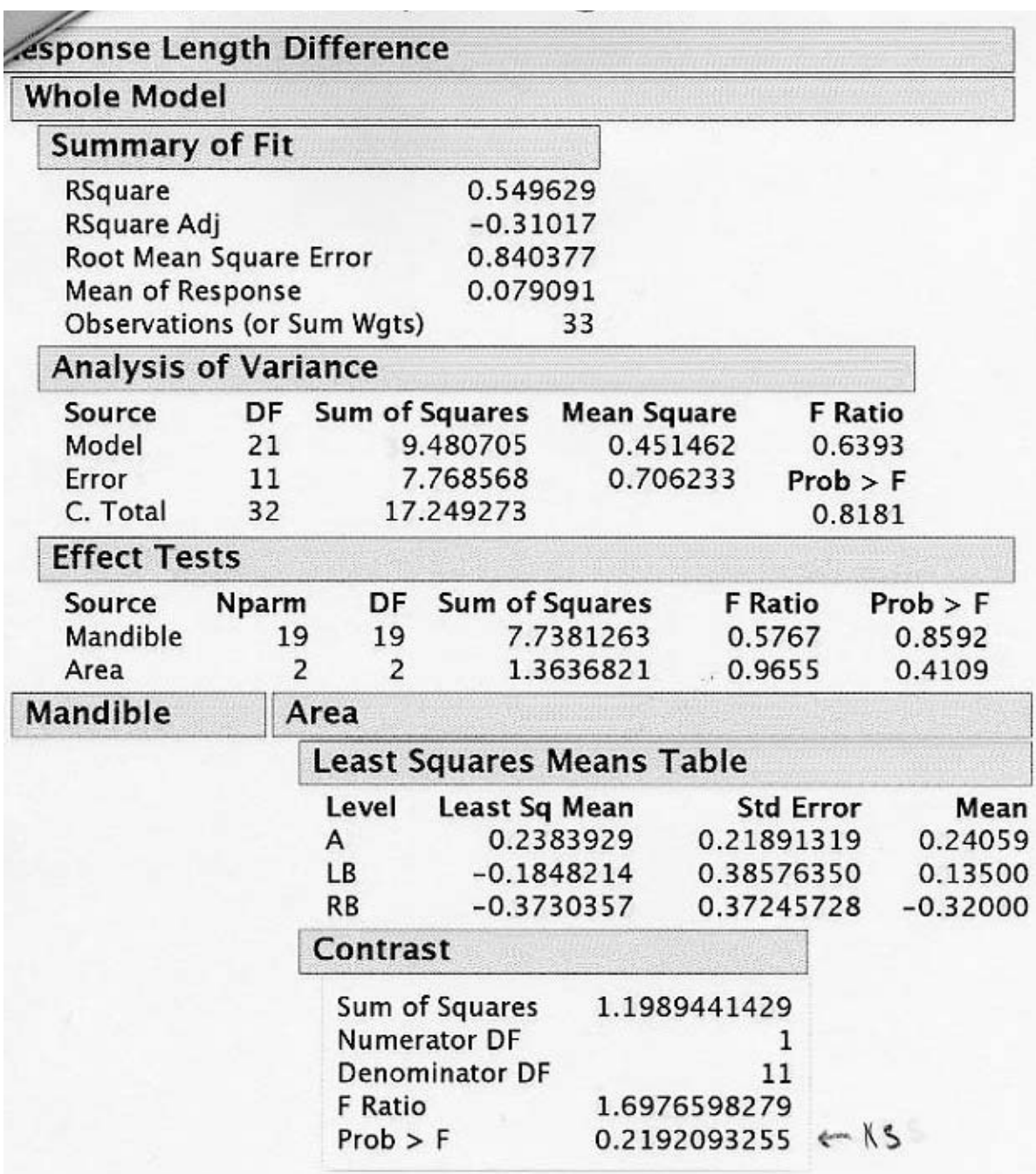


12 Impulses, 90 Degrees - Width and Length

Sheet(1a) No0's.JMP: Fit $Y$ by $X$

Page 11 of 12

Fit $Y$ by $X$ Group

Missing Rows 52

\begin{tabular}{|lr|}
\hline \multicolumn{2}{|l|}{ Oneway Anova } \\
\hline Summary of Fit & \\
\hline Rsquare & 0.050584 \\
Adj Rsquare & 0.040643 \\
Root Mean Square Error & 0.388967 \\
Mean of Response & -0.02753 \\
\hline Observations (or Sum Wgts) & 194 \\
\hline
\end{tabular}

\begin{tabular}{|lrrrrr|}
\hline \multicolumn{7}{l}{ Analysis of Variance } & & & \\
\hline Source & DF & Sum of Squares & Mean Square & F Ratio & Prob > F \\
Defect ID & 2 & 1.539629 & 0.769815 & 5.0882 & 0.0070 \\
Error & 191 & 28.897383 & 0.151295 & & \\
C. Total & 193 & 30.437012 & & & \\
\hline
\end{tabular}

\begin{tabular}{|lrrrrr|}
\hline \multicolumn{6}{|c|}{ Means for Oneway Anova } \\
\hline Level & Number & Mean & Std Error & Lower 95\% & Upper 95\% \\
\hline a & 58 & 0.02569 & 0.05107 & -0.0751 & 0.1264 \\
b & 63 & 0.05524 & 0.04901 & -0.0414 & 0.1519 \\
c & 73 & -0.14123 & 0.04553 & -0.2310 & -0.0514
\end{tabular}

Std Error uses a pooled estimate of error variance

$\left.\begin{array}{|lrrrrrr|}\hline \multicolumn{6}{|l|}{\text { Means and Std Deviations }} \\ \hline \text { Level } & \text { Number } & \text { Mean } & \text { Std Dev } & \text { Std Err Mean } & \text { Lower 95\% } & \text { Upper 95\% } \\ \text { a } & 58 & 0.02569 & 0.305775 & 0.04015 & -0.0547 & 0.1061 \\ \text { b } & 63 & 0.05524 & 0.439512 & 0.05537 & -0.0555 & 0.1659 \\ \text { c } & 73 & -0.14123 & 0.401237 & 0.04696 & -0.2348 & -0.0476\end{array}\right)$ S.

D. fference in measarement of width (Rend-Conv) changes signeficantly according to kind of defect. Each sig dif from other two.

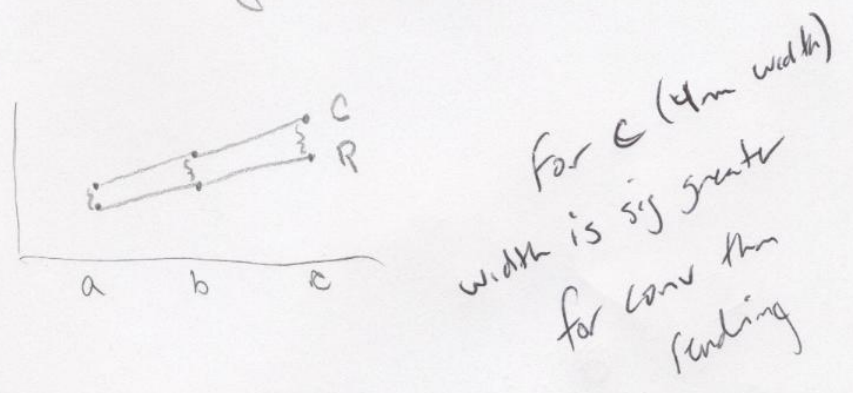


12 Impulses, 90 Degrees - Width and Length

Sheet(1a) No0's.JMP: Fit $Y$ by $X$

Page 12 of 12

\begin{tabular}{|c|c|c|c|c|c|}
\hline \multicolumn{6}{|c|}{ Fit $Y$ by $X$ Group } \\
\hline \multicolumn{6}{|c|}{ Oneway Analysis of Length Difference By Defect ID } \\
\hline Missing Rows & 90 & & & & \\
\hline \multicolumn{6}{|c|}{ Oneway Anova } \\
\hline \multicolumn{6}{|l|}{ Summary of Fit } \\
\hline $\begin{array}{l}\text { Rsquare } \\
\text { Adj Rsquare } \\
\text { Root Mean Squar } \\
\text { Mean of Respons } \\
\text { Observations (or }\end{array}$ & $\begin{array}{l}\text { re Error } \\
\text { se } \\
\text { Sum Wgts) }\end{array}$ & $\begin{array}{r}0.006271 \\
-0.00672 \\
0.66271 \\
-0.39308 \\
156\end{array}$ & & & \\
\hline \multicolumn{6}{|c|}{ Analysis of Variance } \\
\hline $\begin{array}{ll}\text { Source } & \\
\text { Defect ID } \\
\text { Error } \\
\text { C. Total } & 1 \\
\end{array}$ & $\begin{array}{rr}\text { DF } & \text { Sum of } \\
2 & 0 \\
153 & 67 \\
155 & 67 \\
\end{array}$ & $\begin{array}{l}\text { Squares } \\
.424008 \\
.195315 \\
.619323\end{array}$ & $\begin{array}{r}\text { Mean Square } \\
0.212004 \\
0.439185\end{array}$ & $\begin{array}{l}\text { F Ratio } \\
0.4827\end{array}$ & $\begin{array}{r}\text { Prob }>\text { F } \\
0.6180 \\
\end{array}$ \\
\hline \multicolumn{5}{|c|}{ Means for Oneway Anova } & \\
\hline $\begin{array}{lr}\text { Level } & \text { Number } \\
\text { a } & 46 \\
\mathrm{~b} & 50 \\
\mathrm{c} & 60\end{array}$ & $\begin{array}{rr}r & \text { Mean } \\
-0.47370 \\
-0.35900 \\
-0.35967\end{array}$ & $\begin{array}{r}\text { Std Error } \\
0.09771 \\
0.09372 \\
0.08556\end{array}$ & $\begin{array}{rr}r & \text { Lower } 95 \% \\
1 & -0.6667 \\
2 & -0.5442 \\
5 & -0.5287\end{array}$ & $\begin{array}{r}\text { Upper } 95 \% \\
-0.2807 \\
-0.1738 \\
-0.1906\end{array}$ & \\
\hline \multicolumn{6}{|c|}{ Std Error uses a pooled estimate of error variance } \\
\hline \multicolumn{6}{|c|}{ Means and Std Deviations } \\
\hline $\begin{array}{lr}\text { Level } & \text { Number } \\
\mathrm{a} & 46 \\
\mathrm{~b} & 50 \\
\mathrm{c} & 60\end{array}$ & $\begin{array}{r}\text { Mean } \\
-0.47370 \\
-0.35900 \\
-0.35967\end{array}$ & $\begin{array}{l}\text { Std Dev } \\
0.647142 \\
0.697530 \\
0.644518\end{array}$ & $\begin{array}{r}\text { Std Err Mean } \\
0.09542 \\
0.09865 \\
0.08321\end{array}$ & $\begin{array}{r}\text { Lower } 95 \% \\
-0.6659 \\
-0.5572 \\
-0.5262\end{array}$ & $\begin{array}{r}\text { Upper } 95 \% \\
-0.2815 \\
-0.1608 \\
-0.1932\end{array}$ \\
\hline \multicolumn{6}{|c|}{ No.sig dif among meandif. (Rend-Conv.) no matter what kind } \\
\hline
\end{tabular}


12 Impulses, +10 Degrees - Diameter

Sheet(2).jmp: Fit $Y$ by $X$

Page 3 of 6

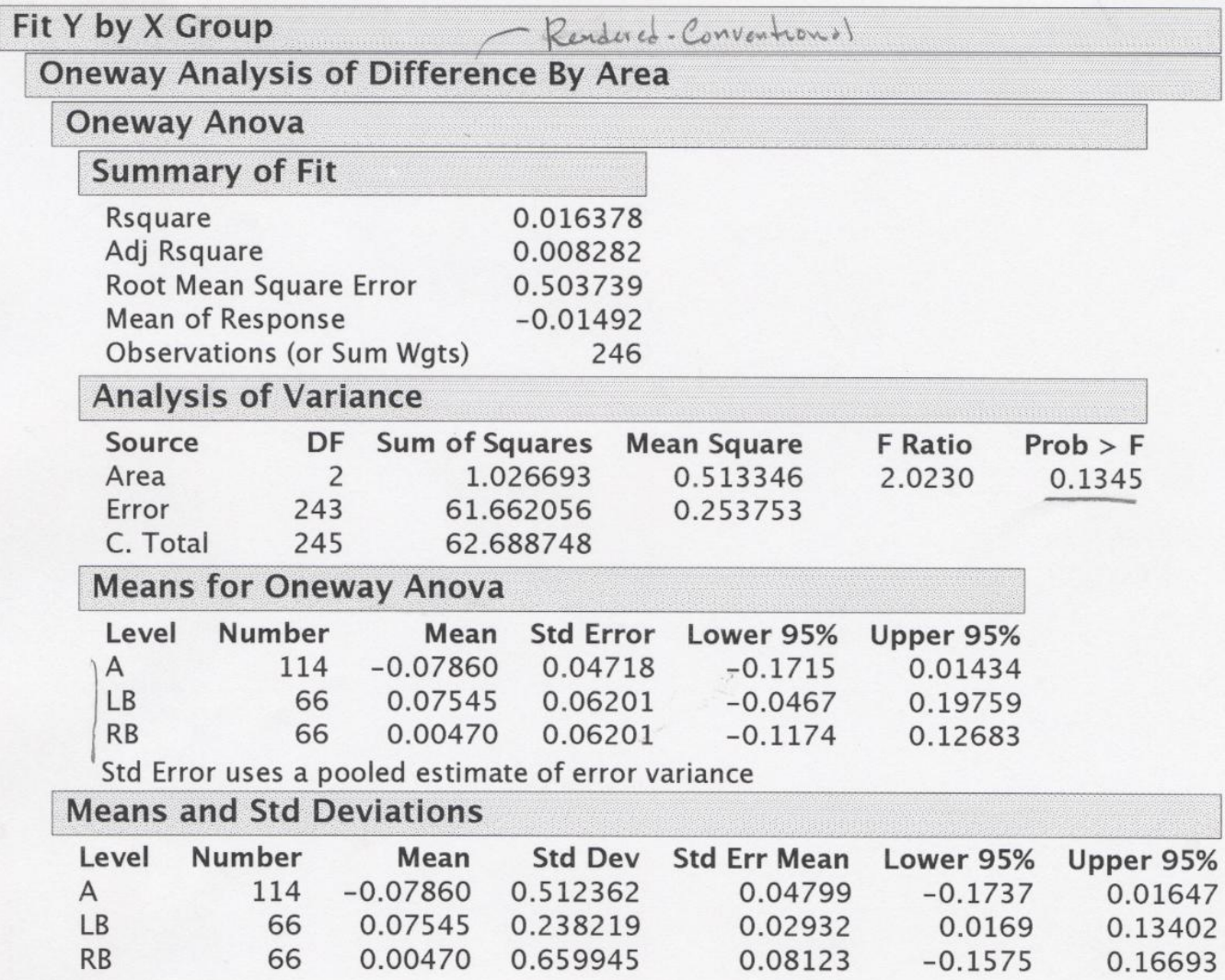

No sig. dif. in difference between the measures obtrined from the twe procedures, irrespective to area of defect. Hence there is no bias due to aree. 
12 Impulses, +10 Degrees - Diameter

Sheet(2).jmp: Fit $Y$ by $X$

Page 6 of 6

\begin{tabular}{|c|c|c|c|c|c|c|}
\hline \multirow{2}{*}{\multicolumn{7}{|c|}{$\begin{array}{l}\text { Fit Y by X Group } \\
\text { Oneway Analysis of Difference By Defect }\end{array}$}} \\
\hline & & & & fect & & \\
\hline \multicolumn{7}{|c|}{ Oneway Anova } \\
\hline \multicolumn{4}{|c|}{ Summary of Fit } & & & \\
\hline \multicolumn{3}{|c|}{ Rsquare } & 0.009725 & & & \\
\hline \multirow{2}{*}{\multicolumn{3}{|c|}{$\begin{array}{l}\text { Adj Rsquare } \\
\text { Root Mean Square Error }\end{array}$}} & 0.001574 & & & \\
\hline & & Error & \multirow{2}{*}{$\begin{array}{r}0.50544 \\
-0.01492\end{array}$} & & & \\
\hline \multicolumn{3}{|c|}{ Mean of Response } & \multirow{2}{*}{\multicolumn{2}{|c|}{$\begin{array}{r}-0.01492 \\
246\end{array}$}} & & \\
\hline \multicolumn{3}{|c|}{ Observations (or Sum Wgts) } & & & & \\
\hline \multicolumn{7}{|c|}{ Analysis of Variance } \\
\hline Source & DF & \multicolumn{2}{|c|}{ Sum of Squares } & lean Square & F Ratio & Prob $>F$ \\
\hline Defect & 2 & \multirow{2}{*}{\multicolumn{2}{|c|}{$\begin{array}{r}0.609620 \\
62.079128\end{array}$}} & 0.304810 & 1.1931 & 0.3050 \\
\hline Error & 243 & & & 0.255470 & & \\
\hline C. Total & 245 & \multicolumn{2}{|c|}{62.688748} & & & \\
\hline \multicolumn{6}{|c|}{ Means for Oneway Anova } & \\
\hline Level & Number & Mean & Std Error & Lower $95 \%$ & Upper $95 \%$ & \\
\hline$a$ & 82 & -0.07732 & 0.05582 & -0.1873 & 0.03263 & \\
\hline b & 82 & 0.04451 & 0.05582 & -0.0654 & 0.15446 & \\
\hline c & 82 & -0.01195 & 0.05582 & -0.1219 & 0.09799 & \\
\hline
\end{tabular}

Std Error uses a pooled estimate of error variance

\begin{tabular}{|lrrrrrr|}
\hline \multicolumn{6}{|l|}{ Means and Std Deviations } \\
\hline Level & Number & Mean & Std Dev & Std Err Mean & Lower 95\% & Upper 95\% \\
a & 82 & -0.07732 & 0.382116 & 0.04220 & -0.1613 & 0.00664 \\
b & 82 & 0.04451 & 0.494788 & 0.05464 & -0.0642 & 0.15323 \\
c & 82 & -0.01195 & 0.612847 & 0.06768 & -0.1466 & 0.12271
\end{tabular}

Means Comparisons

Difference between mean from Rendered-mean from Conv. does not change signifieantly, irrespective to size of diameter 
12 Impulses, +10 Degrees - Width and Length

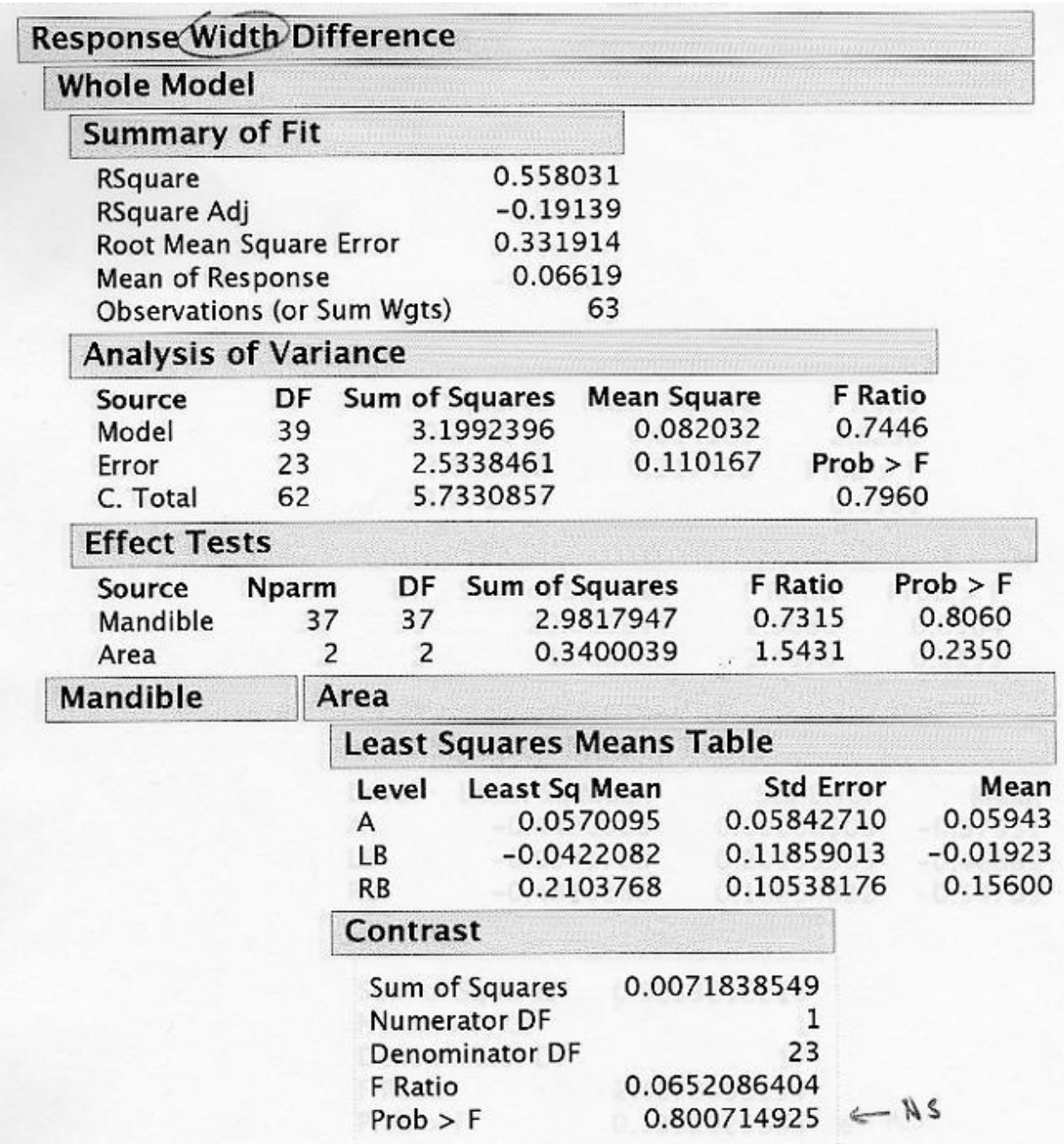


12 Impulses, +10 Degrees - Width and Length

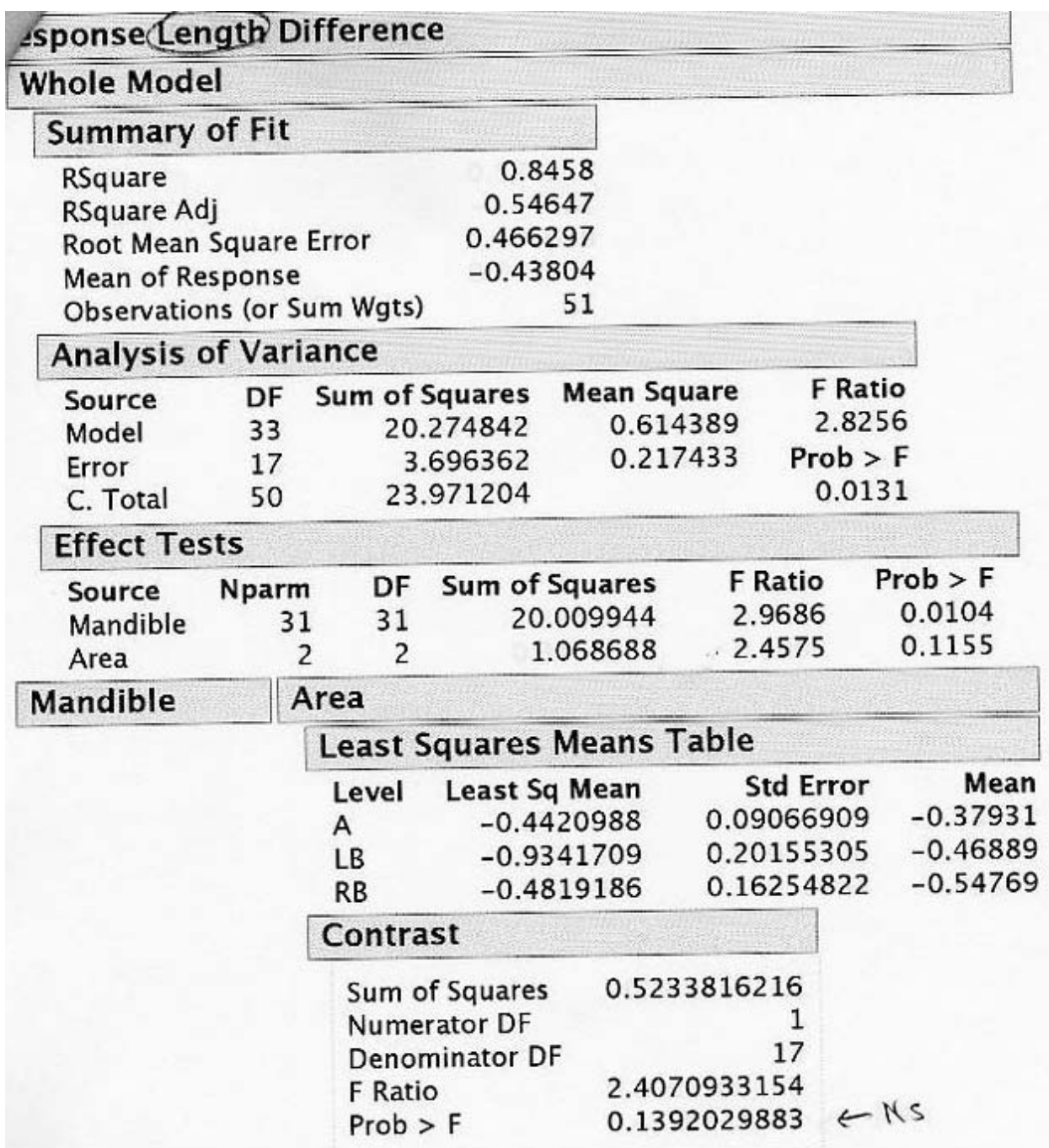


12 Impulses, +10 Degrees - Width and Length

Sheet(2a) No0's.JMP: Fit $Y$ by $X$

Page 11 of 12

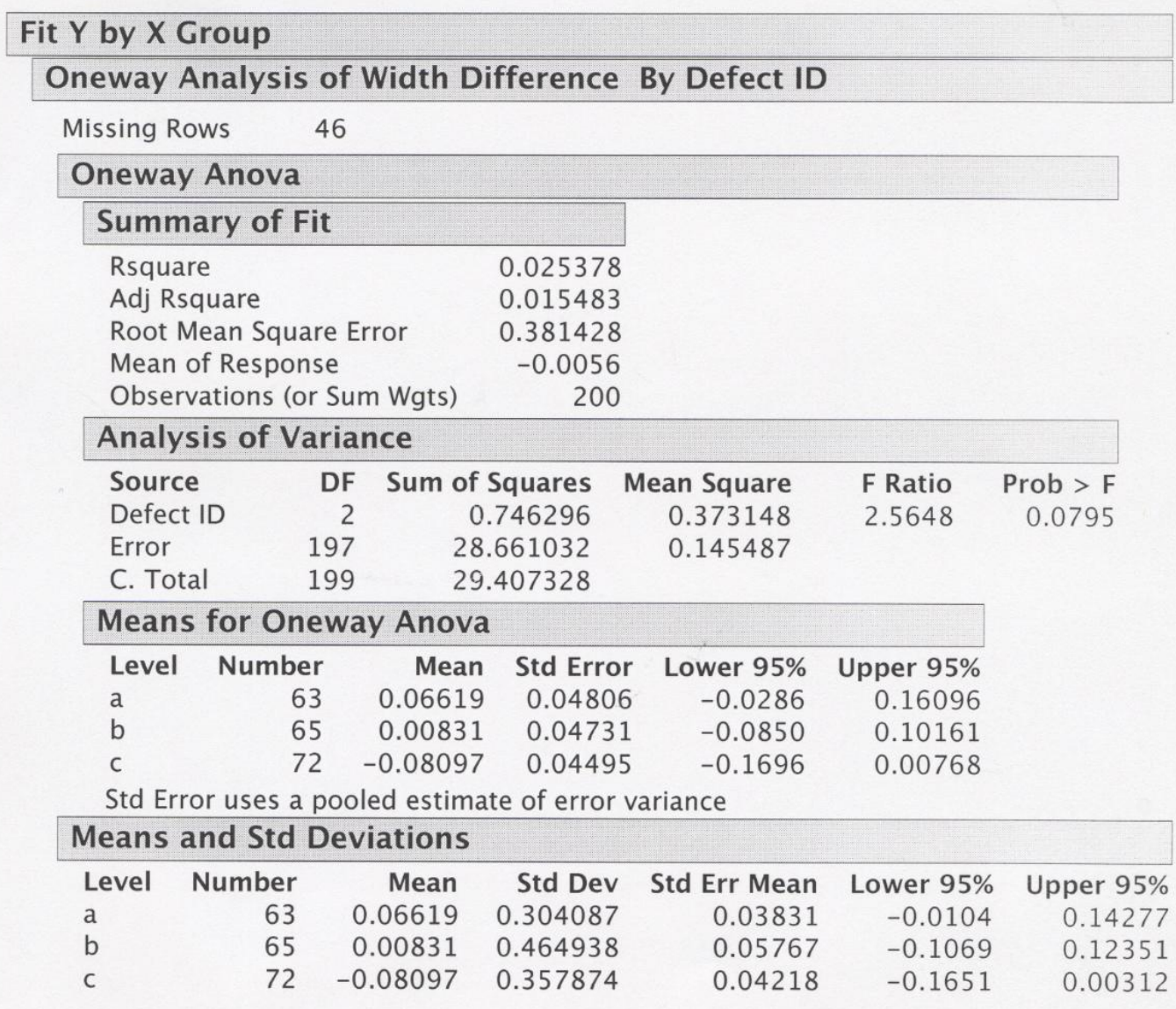

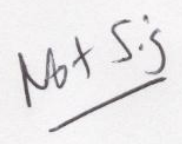


12 Impulses, +10 Degrees - Width and Length

Sheet(2a) No0's.JMP: Fit $Y$ by $X$

Page 12 of 12

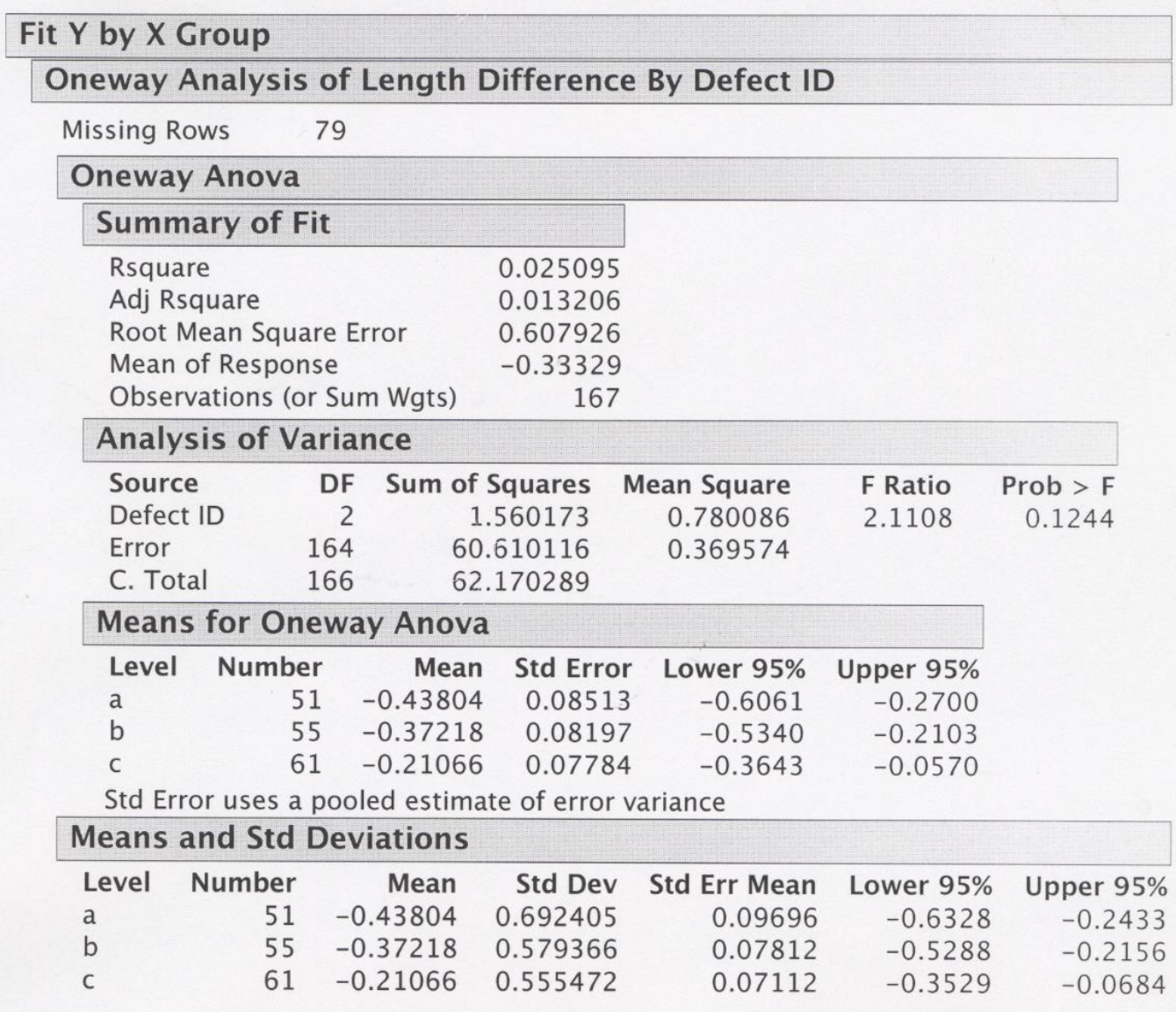


12 Impulses, +20 Degrees - Diameter

Sheet(3).jmp: Fit $Y$ by $X$

Page 3 of 6

Fit $Y$ by $X$ Group C Rendered - Conv.

Oneway Analysis of Difference By Area

Oneway Anova

Summary of Fit

Rsquare

0.008881

Adj Rsquare

0.000724

Root Mean Square Error

0.774083

Mean of Response

$-0.05065$

Observations (or Sum Wgts)

246

\begin{tabular}{|lrrrrr|}
\hline \multicolumn{4}{|l}{ Analysis of Variance } & & \\
\hline Source & DF & Sum of Squares & Mean Square & F Ratio & Prob > F \\
Area & 2 & 1.30470 & 0.652351 & 1.0887 & 0.3383 \\
Error & 243 & 145.60659 & 0.599204 & & \\
\hline C Total & 245 & 146.91130 & &
\end{tabular}

Means for Oneway Anova

Level Number Mean Std Error Lower 95\% Upper 95\%

$\begin{array}{llllll}\text { A } & 114 & -0.05623 & 0.07250 & -0.1990 & 0.08658\end{array}$

$\begin{array}{llllll}\text { LB } & 66 & 0.05333 & 0.09528 & -0.1344 & 0.24102\end{array}$

$\begin{array}{llllll}\text { RB } & 66 & -0.14500 & 0.09528 & -0.3327 & 0.04269\end{array}$

Std Error uses a pooled estimate of error variance

\begin{tabular}{|lrrrrrr|}
\hline \multicolumn{6}{|l|}{ Means and Std Deviations } \\
\hline Level & Number & Mean & Std Dev & Std Err Mean & Lower 95\% & Upper 95\% \\
A & 114 & -0.05623 & 0.947015 & 0.08870 & -0.2320 & 0.11949 \\
LB & 66 & 0.05333 & 0.316905 & 0.03901 & -0.0246 & 0.13124 \\
RB & 66 & -0.14500 & 0.761941 & 0.09379 & -0.3323 & 0.04231
\end{tabular}

Differences between Rend. Conv, means not sig. from area to area 
12 Impulses, +20 Degrees - Diameter

Sheet(3).jmp: Fit $Y$ by $X$

Page 6 of 6

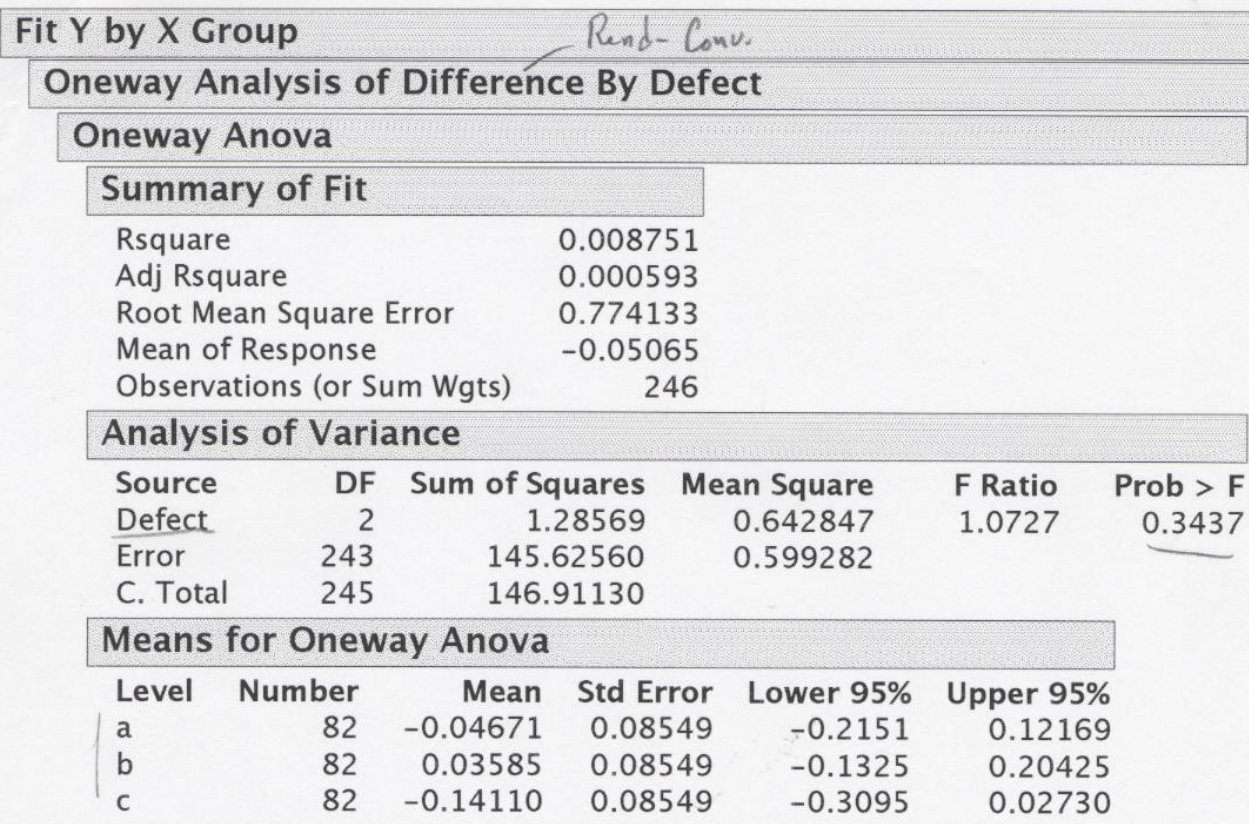

Std Error uses a pooled estimate of error variance

\begin{tabular}{|c|c|c|c|c|c|c|}
\hline Level & Number & Mean & Std Dev & Std Err Mean & Lower 95\% & Upper 95\% \\
\hline $\mathrm{a}$ & 82 & -0.04671 & 0.540350 & 0.05967 & -0.1654 & 0.07202 \\
\hline b & 82 & 0.03585 & 0.814383 & 0.08993 & -0.1431 & 0.21479 \\
\hline C & 82 & -0.14110 & 0.917959 & 0.10137 & -0.3428 & 0.06060 \\
\hline
\end{tabular}


12 Impulses, +20 Degrees - Diameter

Sheet(3).jmp: Fit $Y$ by $X$

Page 6 of 6

Fit $Y$ by $X$ Group
Oneway Analysis of Difference By Defect

Oneway Anova

\section{Summary of Fit}

Rsquare

0.008751

Adj Rsquare

0.000593

Root Mean Square Error

0.774133

Mean of Response $-0.05065$

Observations (or Sum Wgts) 246

\begin{tabular}{|lrrrrr|}
\hline \multicolumn{4}{|l}{ Analysis of Variance } & & \\
\hline Source & DF & Sum of Squares & Mean Square & F Ratio & Prob > F \\
Defect & 2 & 1.28569 & 0.642847 & 1.0727 & 0.3437 \\
\hline Error & 243 & 145.62560 & 0.599282 & & \\
C. Total & 245 & 146.91130 & & &
\end{tabular}

C. Total $245 \quad 146.91130$

\begin{tabular}{|l}
\hline \multicolumn{6}{|l|}{ Means for Oneway Anova } \\
\begin{tabular}{|lrrrrr|}
\hline Level & Number & Mean & Std Error & Lower 95\% & Upper 95\% \\
a & 82 & -0.04671 & 0.08549 & -0.2151 & 0.12169 \\
b & 82 & 0.03585 & 0.08549 & -0.1325 & 0.20425 \\
c & 82 & -0.14110 & 0.08549 & -0.3095 & 0.02730
\end{tabular}
\end{tabular}

Std Error uses a pooled estimate of error variance

\begin{tabular}{|lrrrrrr|}
\hline \multicolumn{6}{|c|}{ Means and Std Deviations } \\
\hline Level & Number & Mean & Std Dev & Std Err Mean & Lower 95\% & Upper 95\% \\
a & 82 & -0.04671 & 0.540350 & 0.05967 & -0.1654 & 0.07202 \\
b & 82 & 0.03585 & 0.814383 & 0.08993 & -0.1431 & 0.21479 \\
c & 82 & -0.14110 & 0.917959 & 0.10137 & -0.3428 & 0.06060
\end{tabular}

Rend-Conv. means not sig. chf. irrespective to size of defat 
12 Impulses, +20 Degrees - Width and Length

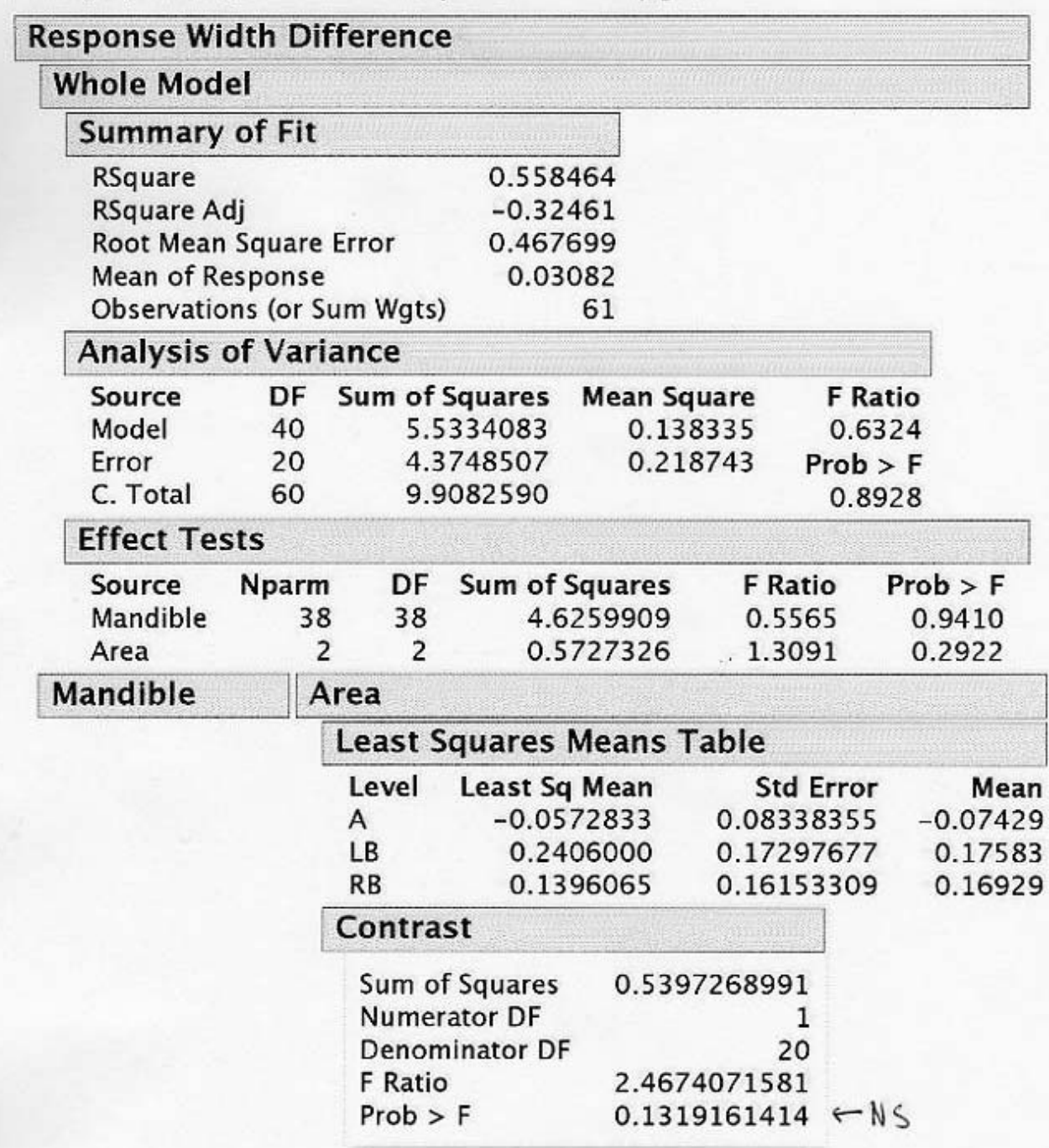


12 Impulses, +20 Degrees - Width and Length

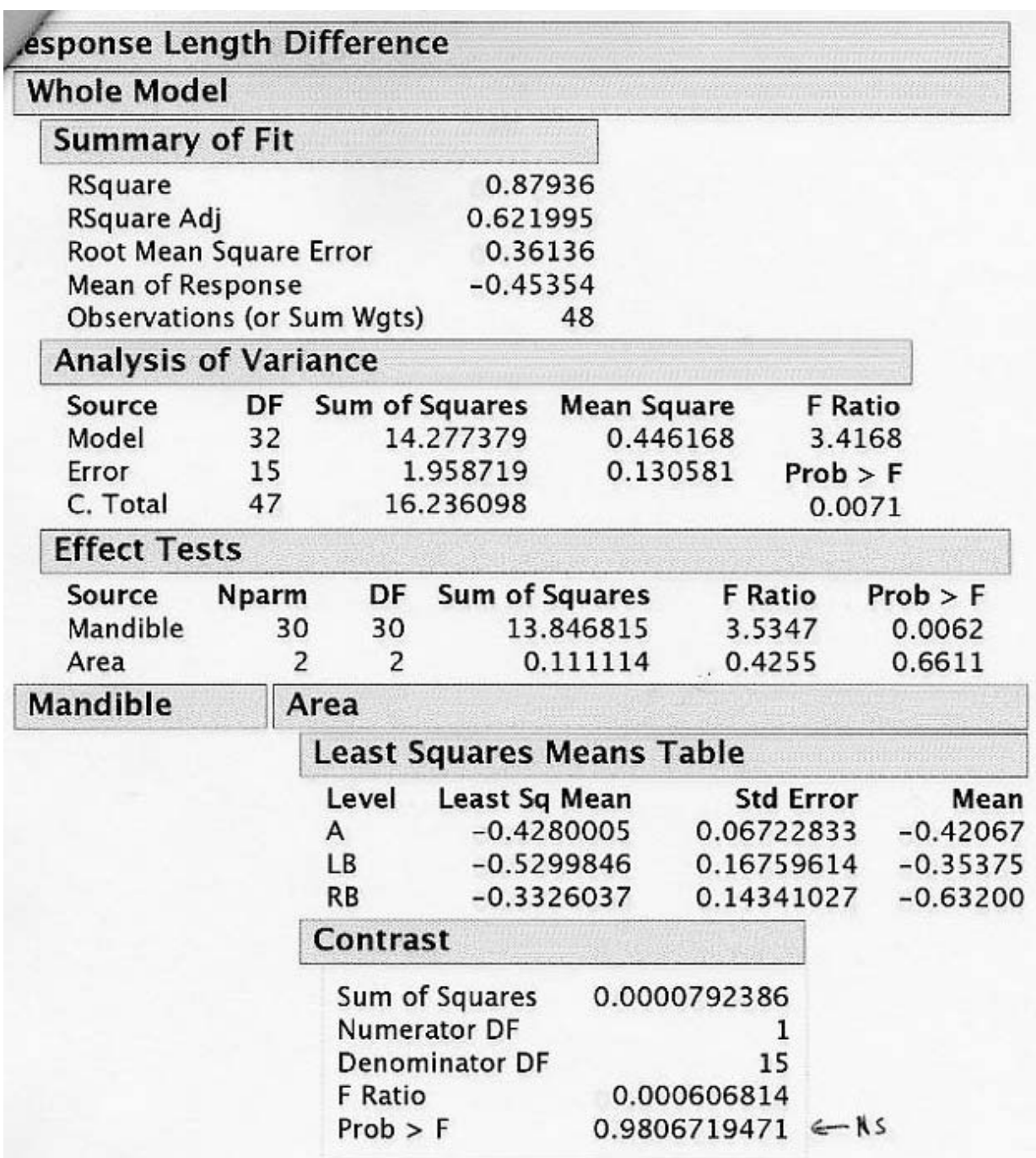


12 Impulses, +20 Degrees - Width and Length

Sheet(3a) No0's.JMP: Fit $Y$ by $X$

Page 11 of 12

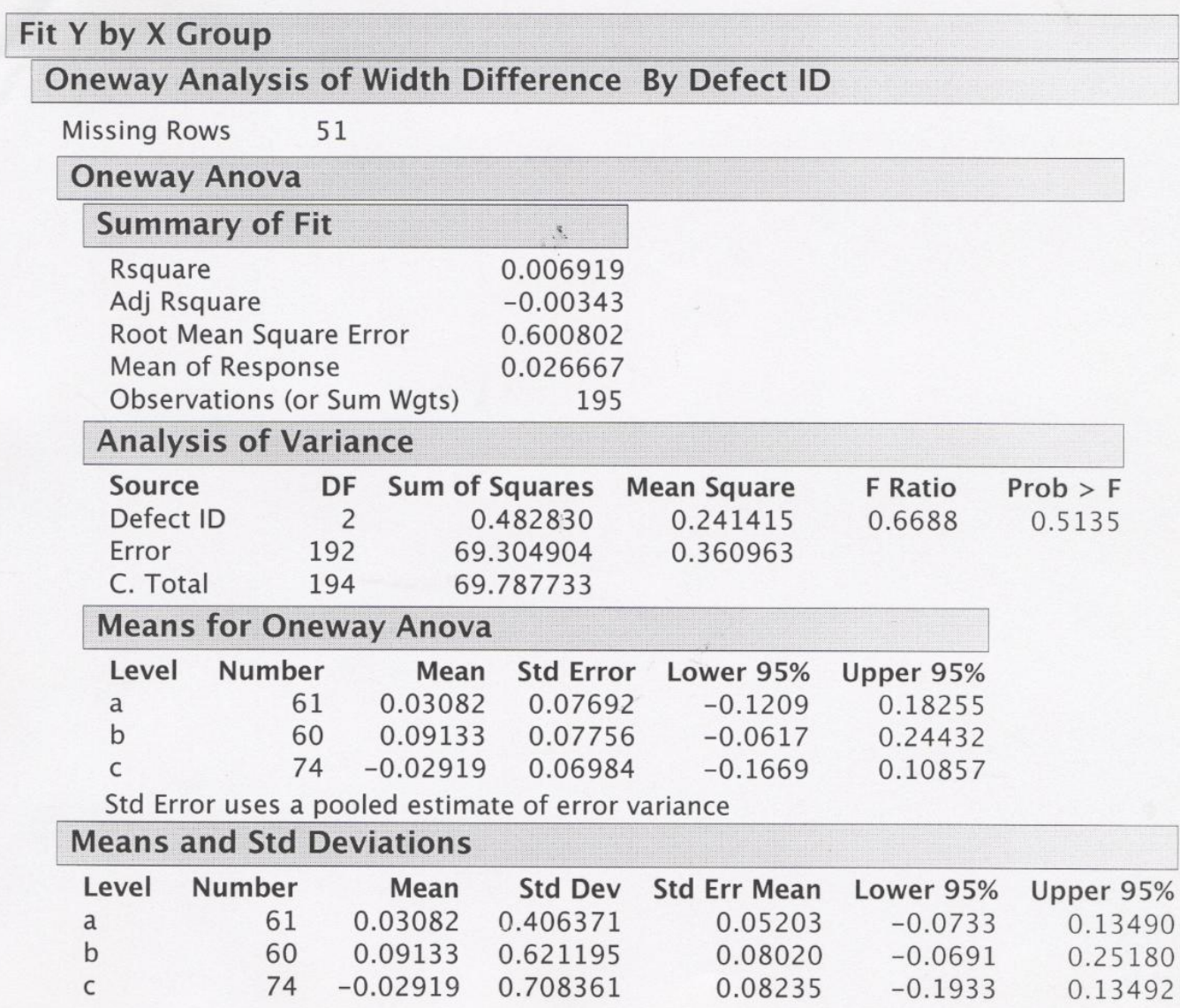


12 Impulses, +20 Degrees - Width and Length

Sheet(3a) No0's.JMP: Fit $Y$ by $X$

Page 12 of 12

Fit $Y$ by $X$ Group
Oneway Analysis of Length Difference By Defect ID

Missing Rows

84

\section{Oneway Anova}

\section{Summary of Fit}

Rsquare

0.027746

Adj Rsquare

0.015517

Root Mean Square Error

0.756177

Mean of Response

$-0.35395$

Observations (or Sum Wgts)

162

\begin{tabular}{|lrrrrr|}
\hline \multicolumn{7}{|l|}{ Analysis of Variance } & & & \\
\hline Source & DF & Sum of Squares & Mean Square & F Ratio & Prob > F \\
Defect ID & 2 & 2.594613 & 1.29731 & 2.2688 & 0.1068 \\
Error & 159 & 90.916859 & 0.57180 & & \\
C. Total & 161 & 93.511472 & & & \\
\hline
\end{tabular}

\section{Means for Oneway Anova}

Level Number Mean

a $\quad 48 \quad-0.45354$

b $\quad 52 \quad-0.45365$

$\begin{array}{ll}52 & -0.45365 \\ 62 & -0.19323\end{array}$

Std Error

0.10914

Lower 95\%

$-0.6691$

Upper $95 \%$

c

0.10486

$-0.6608$

$-0.2380$

$-0.2465$

Std Error uses a pooled estimate of error variance

\begin{tabular}{lrrrrrr}
\multicolumn{6}{c|}{ Means and Std Deviations } \\
\hline Level & Number & Mean & Std Dev & Std Err Mean & Lower 95\% & Upper 95\% \\
a & 48 & -0.45354 & 0.587749 & 0.08483 & -0.6242 & -0.2829 \\
b & 52 & -0.45365 & 0.968427 & 0.13430 & -0.7233 & -0.1840 \\
c & 62 & -0.19323 & 0.663453 & 0.08426 & -0.3617 & -0.0247
\end{tabular}


8 Impulses, 90 Degrees - Diameter

Sheet(4).jmp: Fit $Y$ by $X$

Page 3 of 6

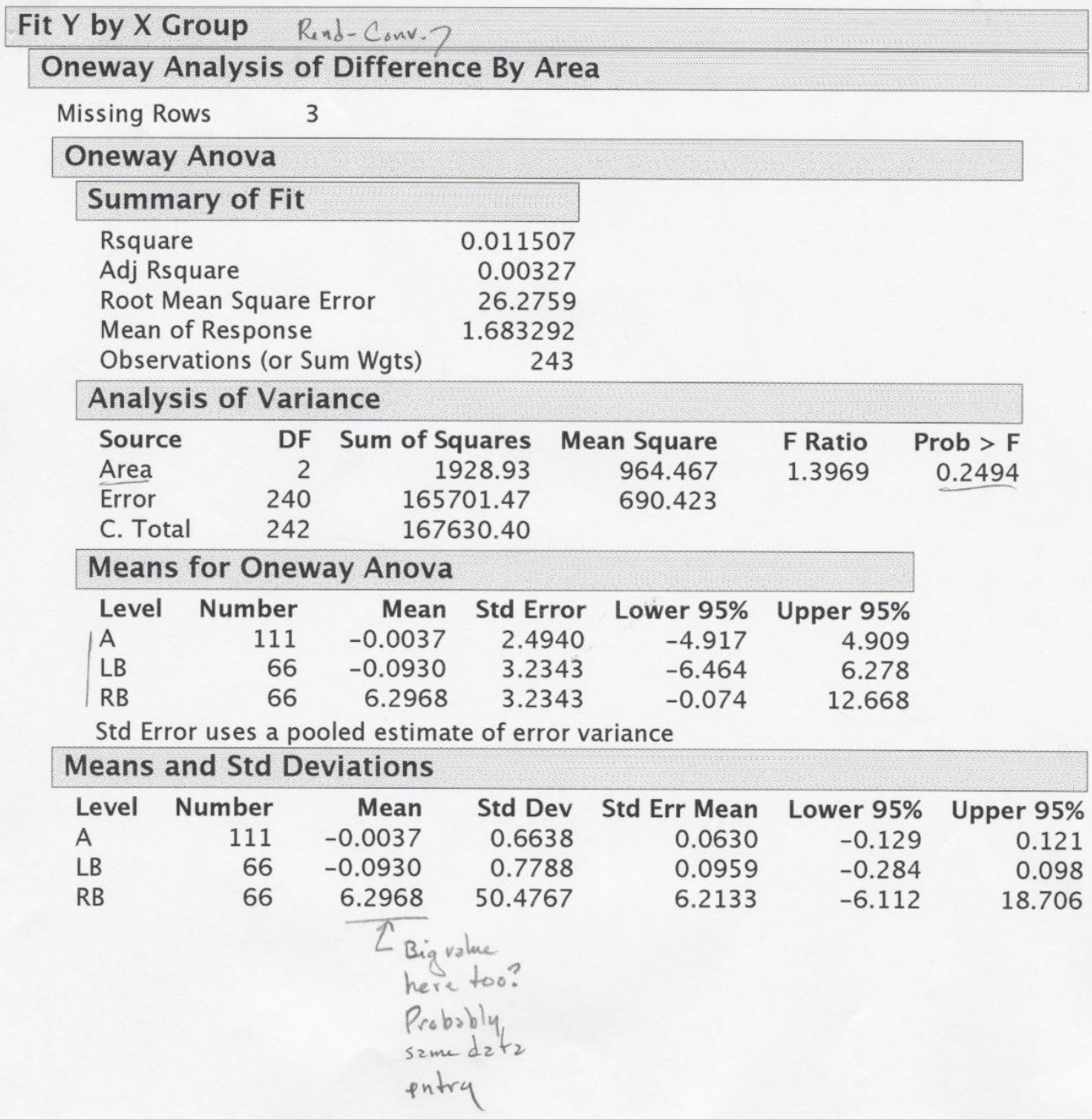


8 Impulses, 90 Degrees - Diameter

Sheet(4).jmp: Fit $Y$ by $X$

Page 6 of 6

Fit $Y$ by $X$ Group
Oneway Analysis of Difference By Defect

Missing Rows 3

Oneway Anova

Summary of Fit

Rsquare

0.007993

Adj Rsquare

$-0.00027$

Root Mean Square Error

26.32256

Mean of Response

1.683292

Observations (or Sum Wgts)

243

\begin{tabular}{|lrrrrr|}
\hline Analysis of Variance & & & \\
\hline Source & DF & Sum of Squares & Mean Square & F Ratio & Prob > F \\
Defect & 2 & 1339.87 & 669.935 & 0.9669 & 0.3817 \\
Error & 240 & 166290.53 & 692.877 & & \\
C. Total & 242 & 167630.40 & & &
\end{tabular}

\section{Means for Oneway Anova}

Level Number Mean Std Error Lower 95\% Upper 95\%

$\begin{array}{llrrrr}\text { a } & 81 & 0.0849 & 2.9247 & -5.676 & 5.846\end{array}$

$\begin{array}{llllll}\text { b } & 81 & -0.0384 & 2.9247 & -5.800 & 5.723\end{array}$

$\begin{array}{llllll}\text { c } & 81 & 5.0033 & 2.9247 & -0.758 & 10.765\end{array}$

Std Error uses a pooled estimate of error variance

Means and Std Deviations

$\begin{array}{lrrrrrr}\text { Level } & \text { Number } & \text { Mean } & \text { Std Dev } & \text { Std Err Mean } & \text { Lower 95\% } & \text { Upper 95\% } \\ \text { a } & 81 & 0.0849 & 0.9176 & 0.1020 & -0.118 & 0.288 \\ \text { b } & 81 & -0.0384 & 0.6173 & 0.0686 & -0.175 & 0.098 \\ \text { c } & 81 & 5.0033 & 45.5786 & 5.0643 & -5.075 & 15.082\end{array}$

Sameproblem 
8 Impulses, 90 Degrees - Width and Length

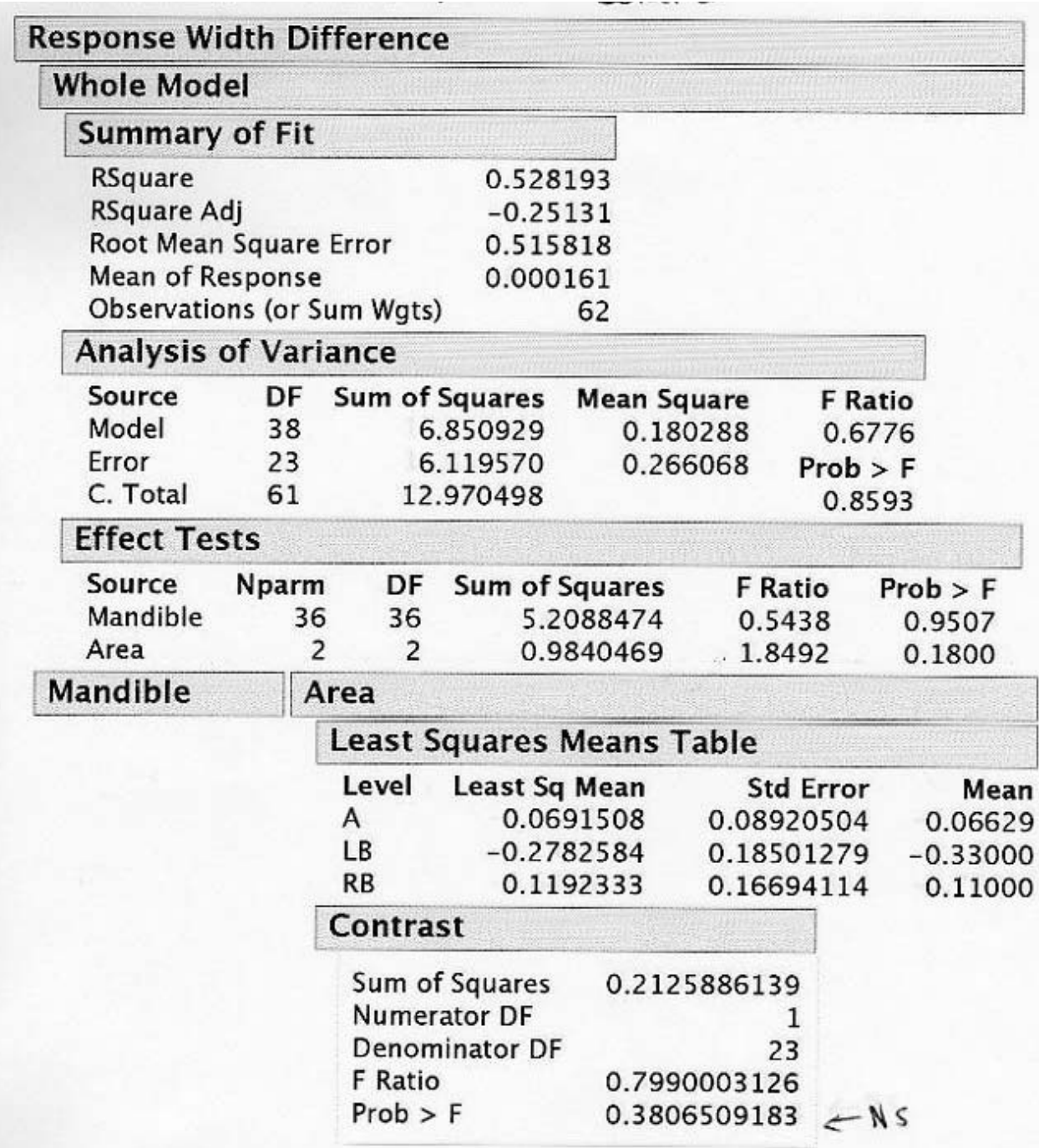


8 Impulses, 90 Degrees - Width and Length

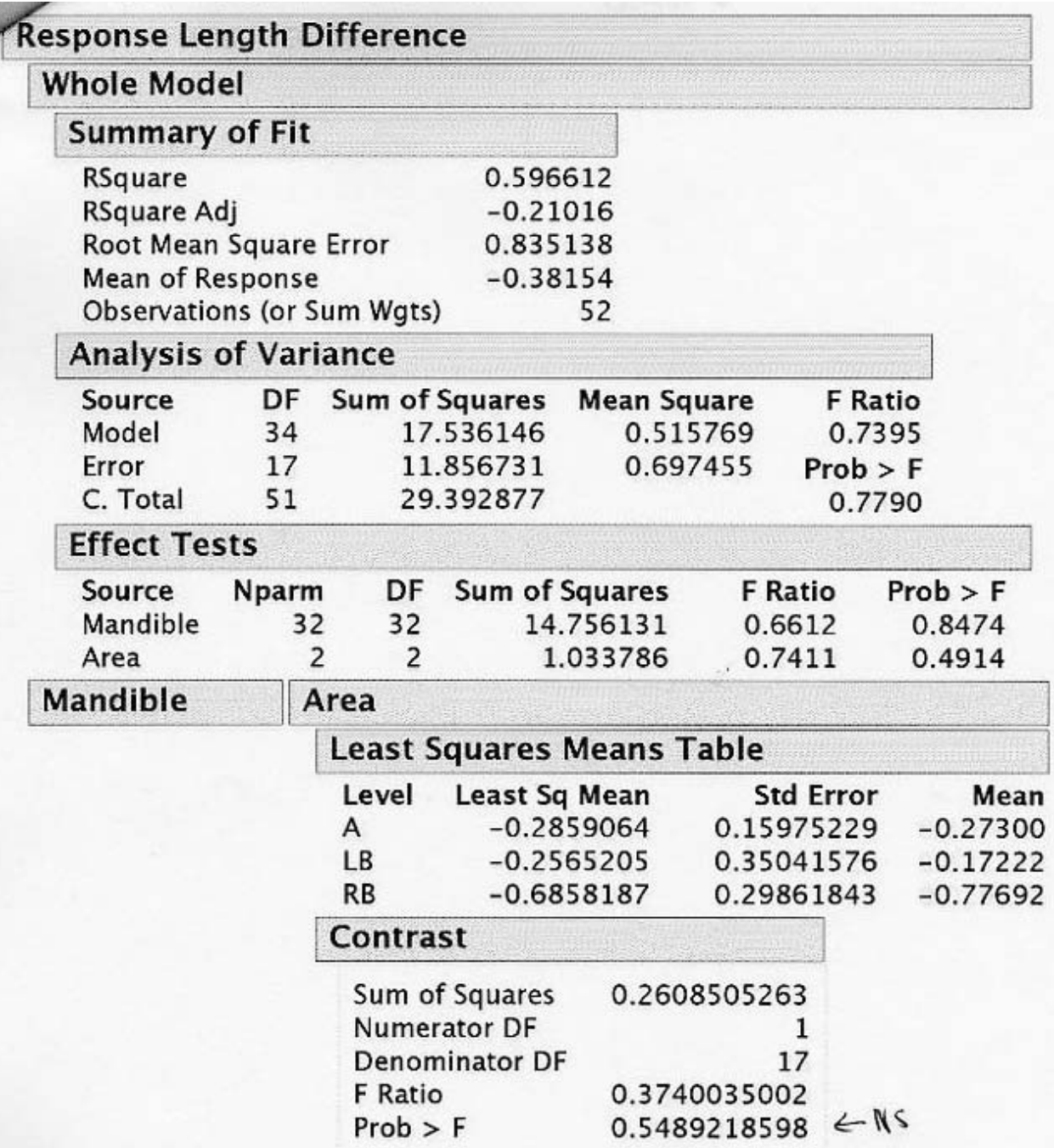


8 Impulses, 90 Degrees - Width and Length

Sheet(4a) NoO's.JMP: Fit $Y$ by $X$

Page 11 of 12

\begin{tabular}{|l|l|}
\hline Fit $Y$ by $X$ Group \\
Oneway Analysis of Width Difference By Defect ID
\end{tabular}

Missing Rows 43

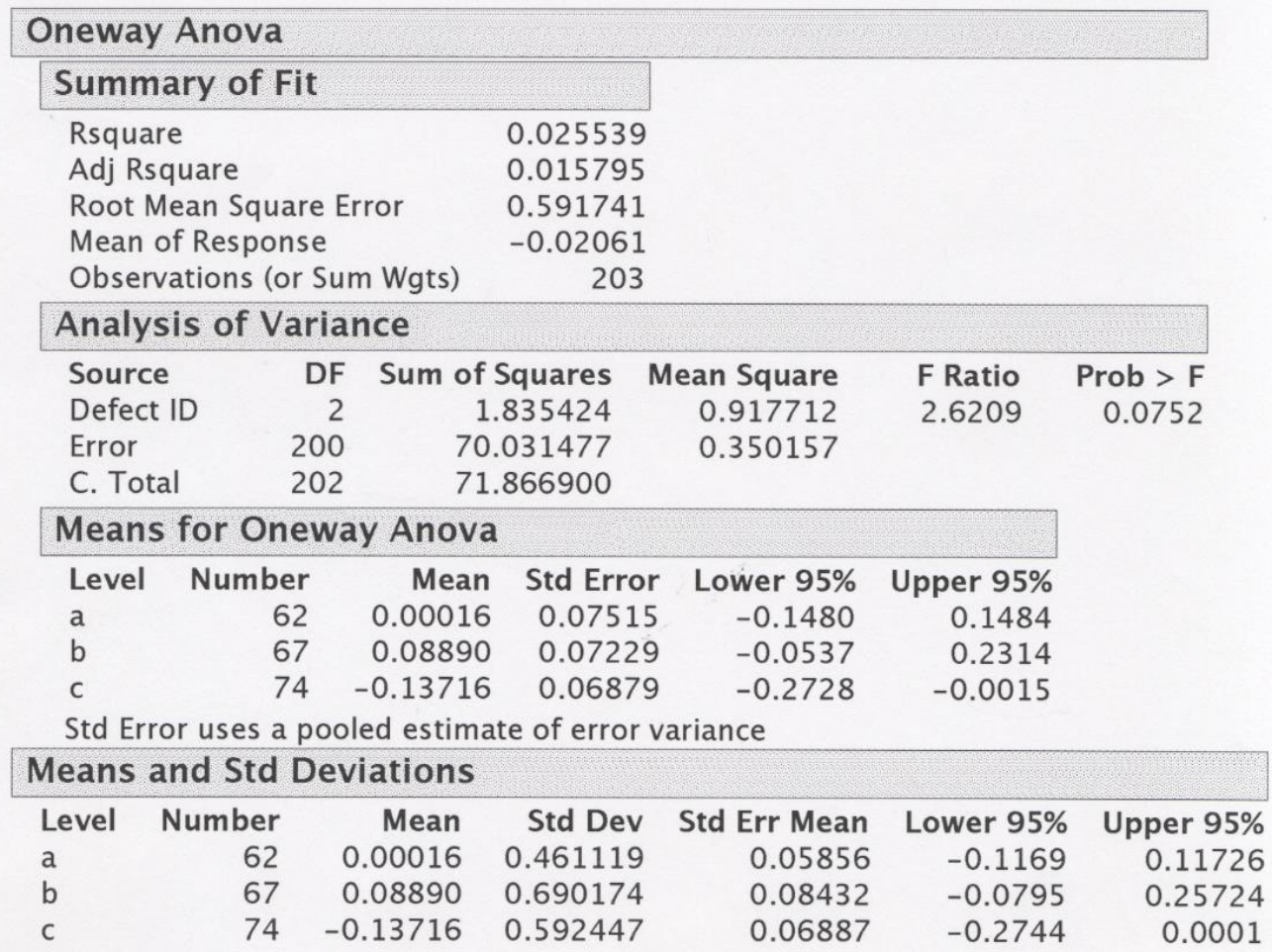


8 Impulses, 90 Degrees - Width and Length

Sheet(4a) NoO's.JMP: Fit $Y$ by $X$

Page 12 of 12

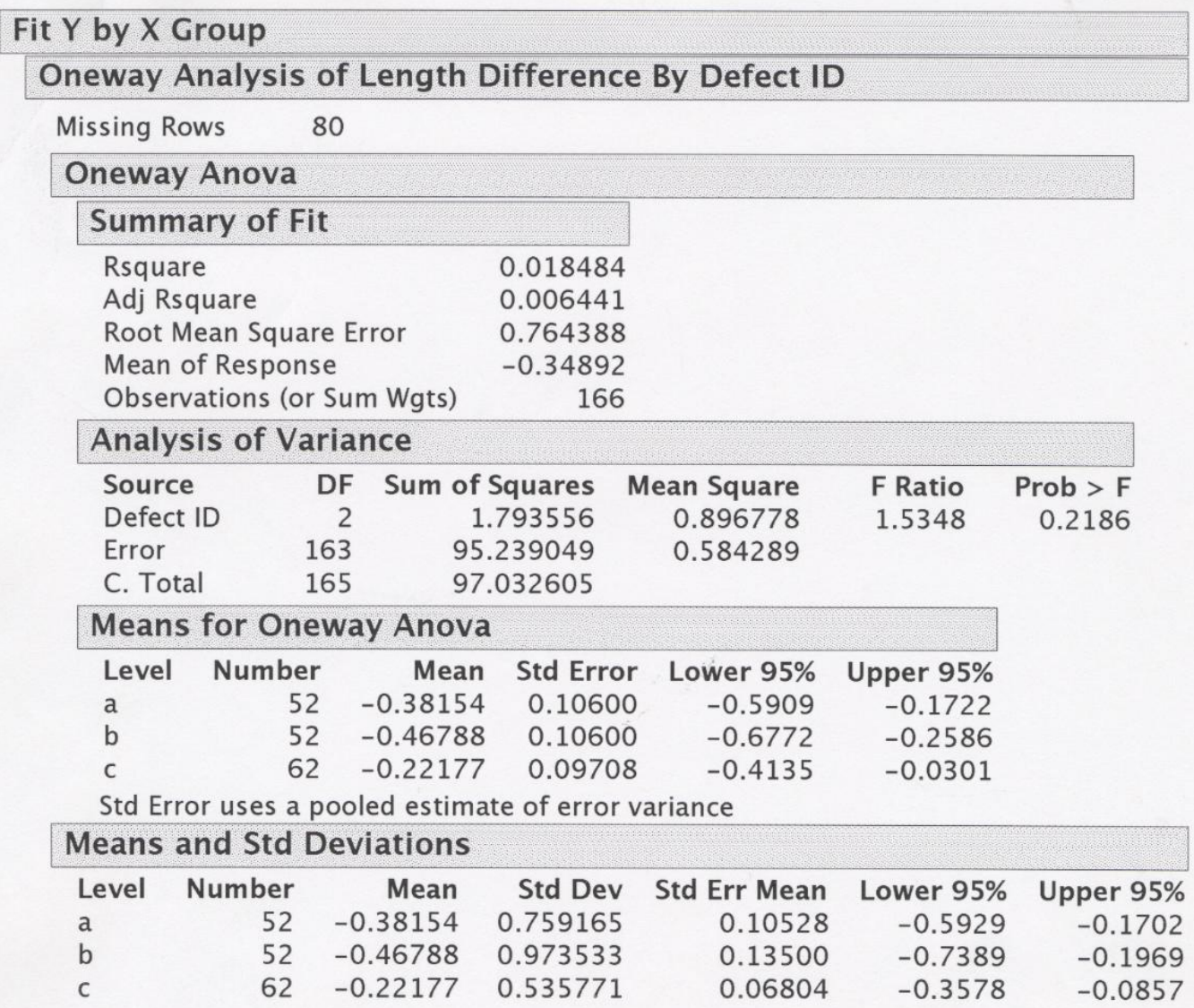


18 Impulses, 90 Degrees - Diameter

Sheet(5).jmp: Fit $Y$ by $X$

Page 3 of 6

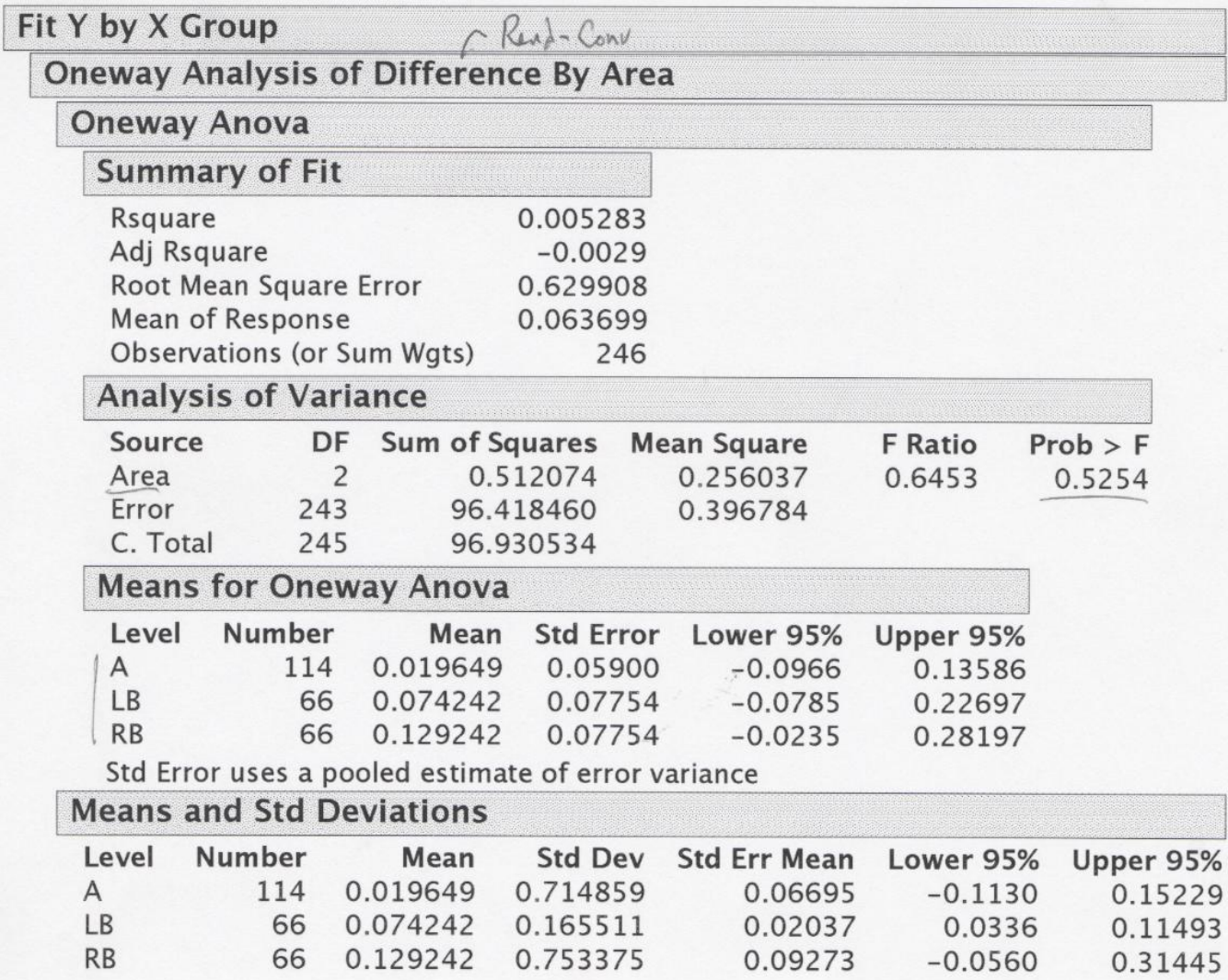

(Rend-Conv) means not sig. def. from one arez to znother 
18 Impulses, 90 Degrees - Diameter

Sheet(5).jmp: Fit $Y$ by $X$

Page 6 of 6

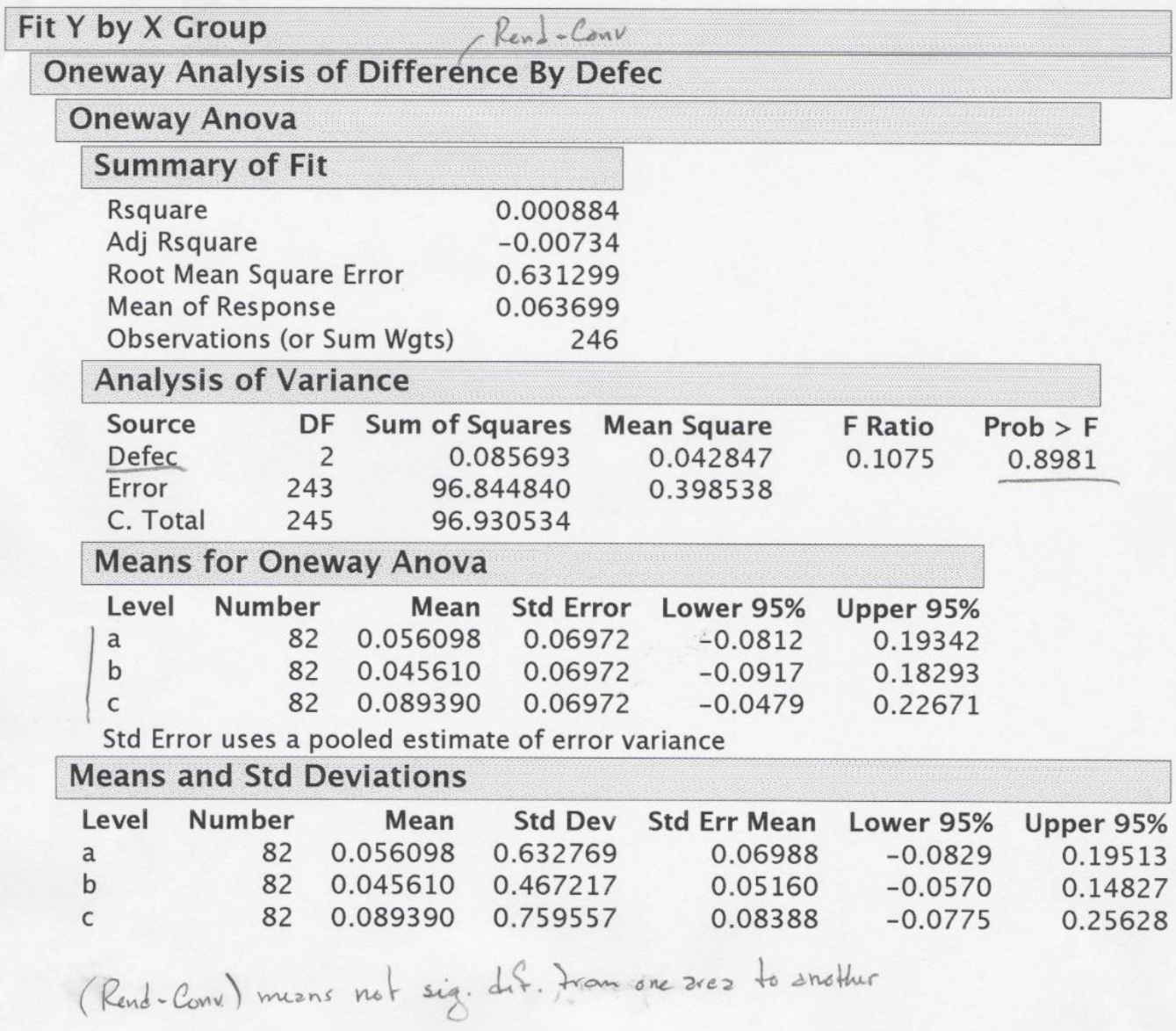


18 Impulses, 90 Degrees - Width and Length

\begin{tabular}{|c|c|c|c|c|c|c|}
\hline \multicolumn{7}{|c|}{ Response Width Difference } \\
\hline \multicolumn{7}{|l|}{ Whole Model } \\
\hline \multicolumn{7}{|l|}{ Summary of Fit } \\
\hline \multicolumn{2}{|c|}{$\begin{array}{l}\text { RSquare } \\
\text { RSquare Adj } \\
\text { Root Mean Square Error } \\
\text { Mean of Response } \\
\text { Observations (or Sum Wgts) }\end{array}$} & $\begin{array}{r}0.5515 \\
-0.158 \\
0.24 \\
-0.016\end{array}$ & $\begin{array}{r}574 \\
843 \\
355 \\
635 \\
63\end{array}$ & & & \\
\hline \multicolumn{7}{|c|}{ Analysis of Variance } \\
\hline $\begin{array}{ll}\text { Source } & \text { DF } \\
\text { Model } & 38 \\
\text { Error } & 24 \\
\text { C. Total } & 62\end{array}$ & \multicolumn{2}{|c|}{$\begin{array}{r}\text { Sum of Squares } \\
1.7510601 \\
1.4236003 \\
3.1746603\end{array}$} & $\begin{array}{r}\text { Mean Sc } \\
0.04 \\
0.05\end{array}$ & $\begin{array}{l}\text { are } \\
081 \\
317\end{array}$ & $\begin{array}{r}\text { F Ra } \\
0.77 \\
\text { Prob > } \\
0.76\end{array}$ & $\begin{array}{r}\text { tio } \\
69 \\
>\mathrm{F} \\
20\end{array}$ \\
\hline \multicolumn{7}{|l|}{ Effect Tests } \\
\hline $\begin{array}{lr}\text { Source } & \text { Nparm } \\
\text { Mandible } & 36 \\
\text { Area } & 2\end{array}$ & $\begin{array}{r}\text { DF } \\
36 \\
2\end{array}$ & \multicolumn{2}{|c|}{$\begin{array}{r}\text { Sum of Squares } \\
1.7091002 \\
0.0355831\end{array}$} & \multicolumn{2}{|c|}{$\begin{array}{l}\text { F Ratio } \\
0.8004 \\
0.2999\end{array}$} & $\begin{array}{r}\text { Prob }>\text { F } \\
0.7328 \\
0.7436\end{array}$ \\
\hline Mandible & rea & & & & & \\
\hline \multicolumn{7}{|c|}{ Least Squares Means Table } \\
\hline \multicolumn{2}{|r|}{$\begin{array}{l}\text { Level } \\
\text { A } \\
\text { LB } \\
\text { RB }\end{array}$} & \multicolumn{2}{|c|}{$\begin{array}{r}\text { Least Sq Mean } \\
-0.0351737 \\
0.0430523 \\
-0.0069948\end{array}$} & $\begin{array}{l}S \\
0.0 \\
0.08 \\
0.0\end{array}$ & $\begin{array}{l}\text { d Error } \\
214816 \\
886586 \\
457628\end{array}$ & $\begin{array}{r}\text { Mean } \\
-0.03600 \\
0.03167 \\
-0.00937\end{array}$ \\
\hline \multicolumn{6}{|c|}{ Contrast } & \\
\hline & \multicolumn{2}{|c|}{$\begin{array}{l}\text { Sum of Squares } \\
\text { Numerator DF } \\
\text { Denominator DF } \\
\text { F Ratio } \\
\text { Prob > F }\end{array}$} & \multicolumn{3}{|c|}{$\begin{array}{r}0.0279540019 \\
1 \\
24 \\
0.4712671557 \\
0.4989842634\end{array}$} & \\
\hline
\end{tabular}


18 Impulses, 90 Degrees - Width and Length

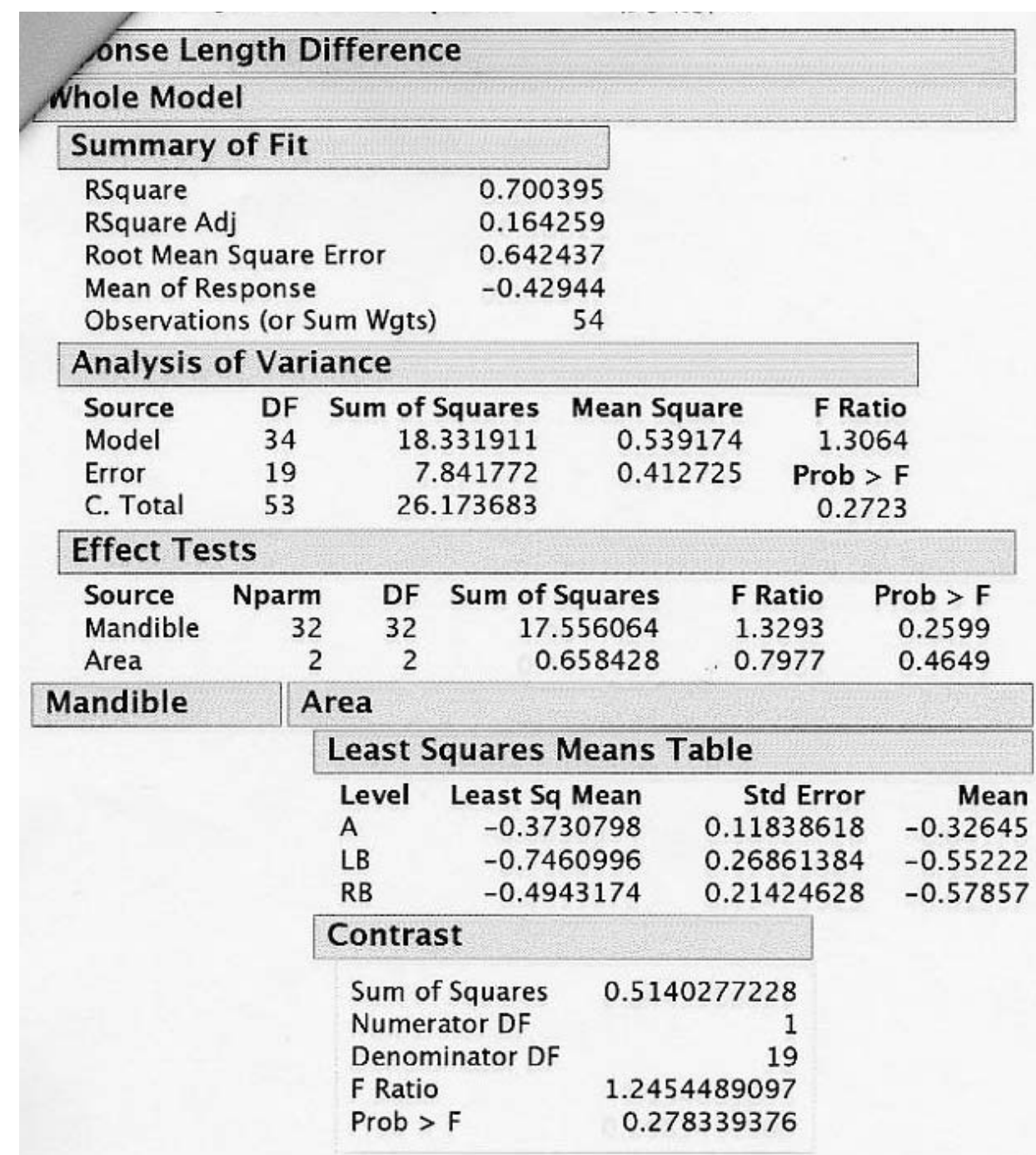


18 Impulses, 90 Degrees - Width and Length

Sheet(5a) No0's.JMP: Fit $Y$ by $X$

Page 11 of 12

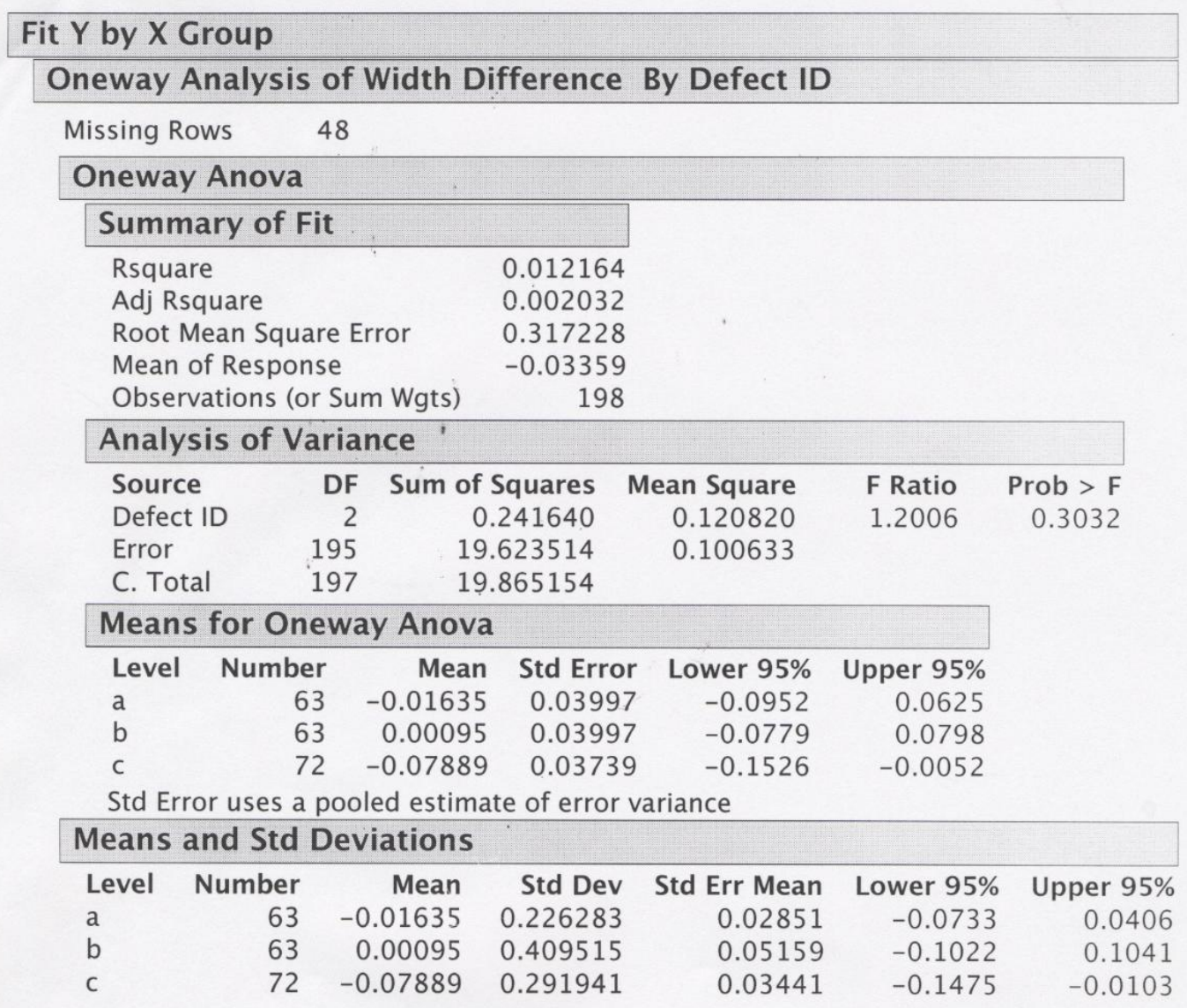

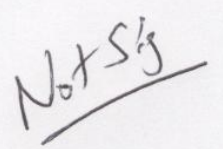


18 Impulses, 90 Degrees - Width and Length

Sheet(5a) No0's.JMP: Fit $Y$ by $X$

Page 12 of 12

Fit $Y$ by $X$ Group

Oneway Analysis of Length Difference By Defect ID

Missing Rows $\quad 78$

Oneway Anova

Summary of Fit

Rsquare

Adj Rsquare

0.020321

Root Mean Square Error $\quad 0.694244$

Mean of Response $\quad-0.36292$

Observations (or Sum Wgtș) . 168

\begin{tabular}{|c|c|c|c|c|c|}
\hline \multicolumn{6}{|c|}{ Analysis of Variance } \\
\hline Source & DF & Sum of Squares & Mean Square & F Ratio & Prob $>F$ \\
\hline Defect ID & 2 & 1.649537 & 0.824768 & 1.7112 & 0.1838 \\
\hline Error & 165 & 79.525934 & 0.481975 & & \\
\hline C. Total & 167 & 81.175471 & & & \\
\hline
\end{tabular}

$\begin{array}{lll}\text { C. Total } & 167 & 81.175471\end{array}$

\begin{tabular}{|lrrrrr|}
\hline \multicolumn{6}{|l|}{ Means for Oneway Anova } \\
\hline Level & Number & Mean & Std Error & Lower 95\% & Upper 95\% \\
a & 54 & -0.42944 & 0.09447 & -0.6160 & -0.2429 \\
b & 53 & -0.44585 & 0.09536 & -0.6341 & -0.2576 \\
c & 61 & -0.23197 & 0.08889 & -0.4075 & -0.0565
\end{tabular}

Std Error uses a pooled estimate of error variance

Means and Std Deviations

$\begin{array}{lrrrrrr}\text { Level } & \text { Number } & \text { Mean } & \text { Std Dev } & \text { Std Err Mean } & \text { Lower 95\% } & \text { Upper 95\% } \\ \text { a } & 54 & -0.42944 & 0.702740 & 0.09563 & -0.6213 & -0.2376 \\ \text { b } & 53 & -0.44585 & 0.813524 & 0.11175 & -0.6701 & -0.2216 \\ \text { c } & 61 & -0.23197 & 0.561806 & 0.07193 & -0.3759 & -0.0881\end{array}$

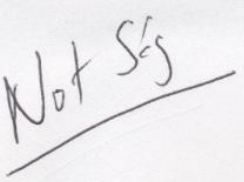




\section{APPENDIX G}

\section{STATISTICAL ANALYSIS - DENTATE MANDIBLE PROJECT}


defect02- Fit Least Squares

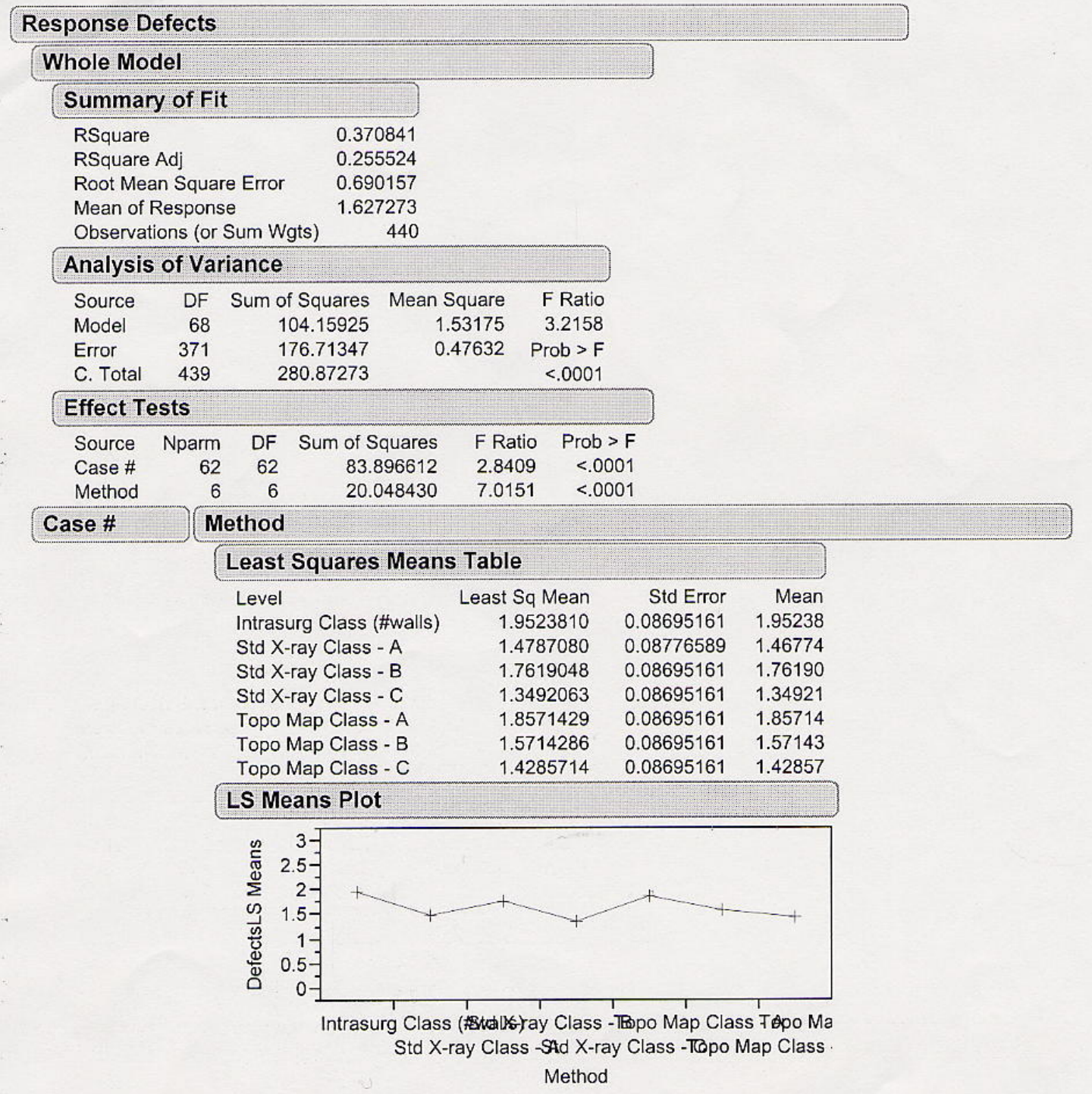


defect02- Fit Least Squares

\section{Response Defects}

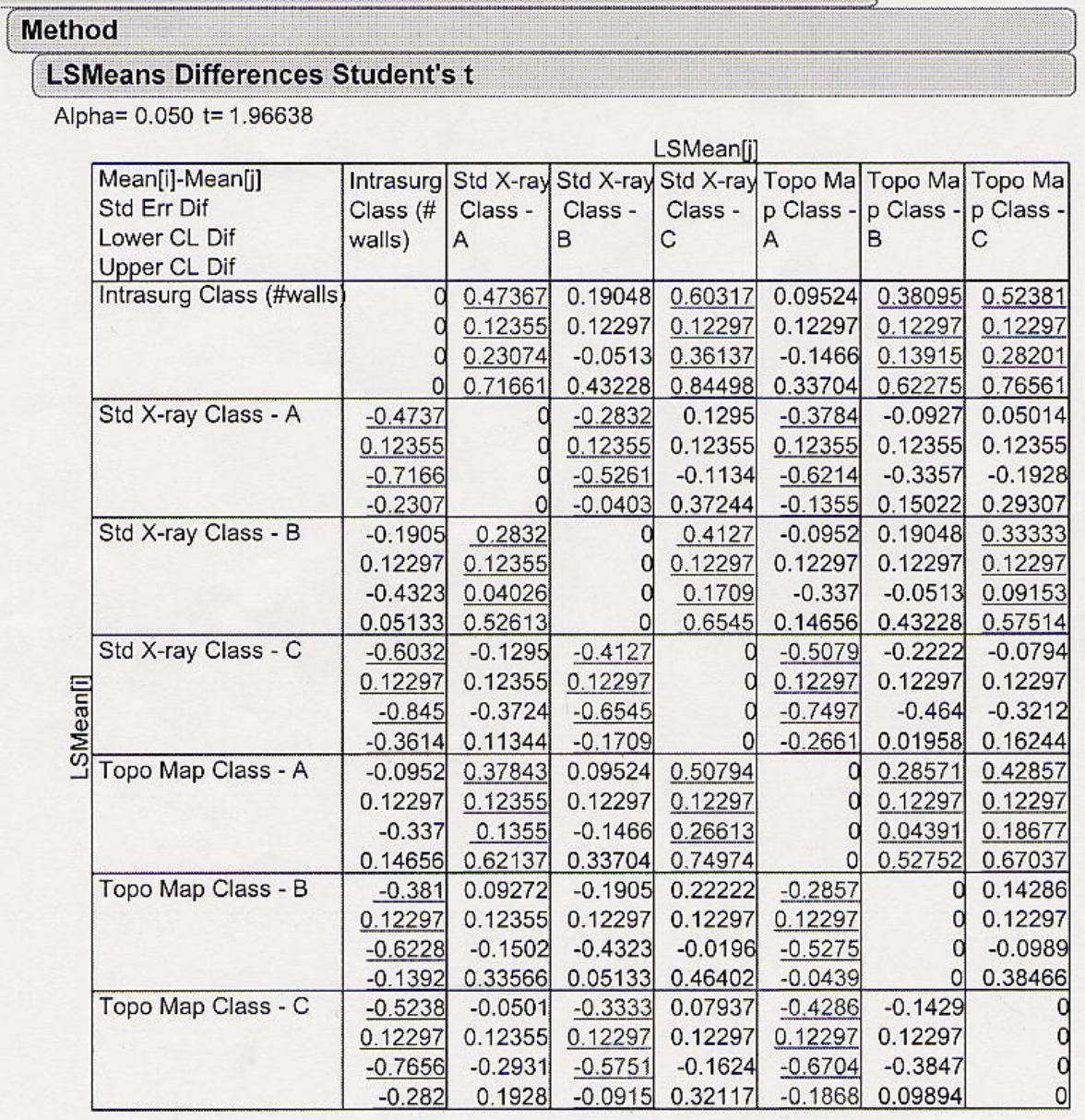

Level

Intrasurg Class (\#walls) A

Topo Map Class - A

Std X-ray Class - B

Topo Map Class - B

Std X-ray Class - A

Topo Map Class - C

Std $\mathrm{X}$-ray Class - C

Levels not connected by same letter are significantly different
Least Sq Mean

1.9523810

1.8571429

1.7619048

B C $\quad 1.5714286$

C $\quad 1.4787080$

C $\quad 1.4285714$

C $\quad 1.3492063$ 
defect01- Fit $Y$ by $X 3$

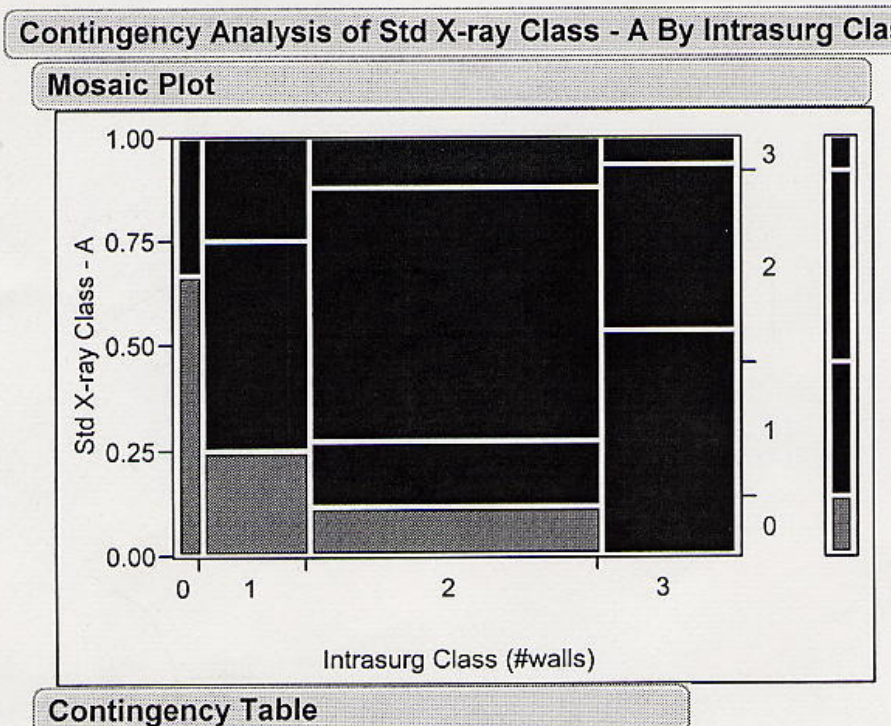

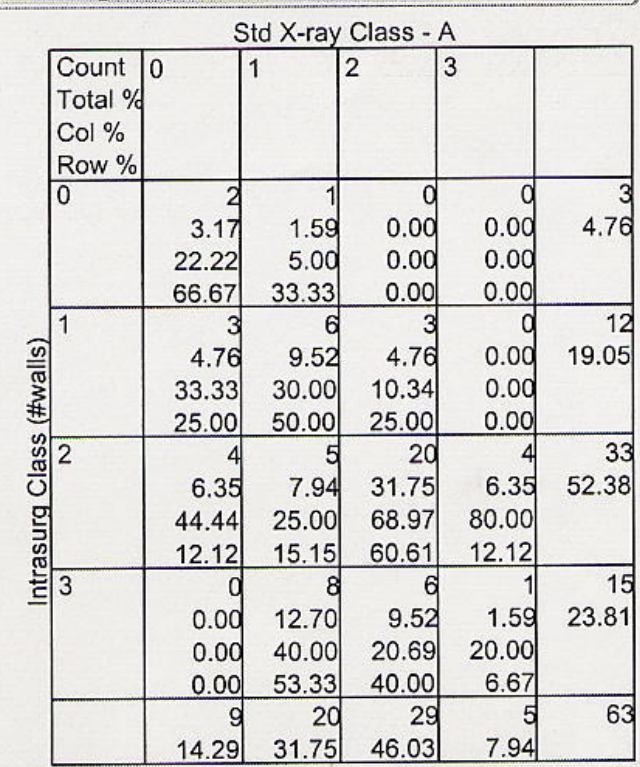

\begin{tabular}{lrrr}
\hline Tests & & & \\
\hline Source & DF & -LogLike & RSquare (U) \\
Model & 9 & 11.675637 & 0.154 \\
Error & 51 & 63.953415 & \\
C. Total & 60 & 75.629052 & \\
N & 63 & & \\
& & & \\
Test & ChiSquare & Prob $>$ ChiSq \\
Likelihood Ratio & 23.351 & 0.0055 \\
Pearson & 21.428 & 0.0109
\end{tabular}

Warning: $20 \%$ of cells have expected count less than 5 , ChiSquare suspect

Warning: average cell count less than 5, LR ChiSquare suspect

$$
\begin{array}{rr}
\text { Kappa } & \text { Std Err } \\
0.197753 & 0.079936
\end{array}
$$

Kappa measures the degree of agreement. 
defect01- Fit $Y$ by $X 3$

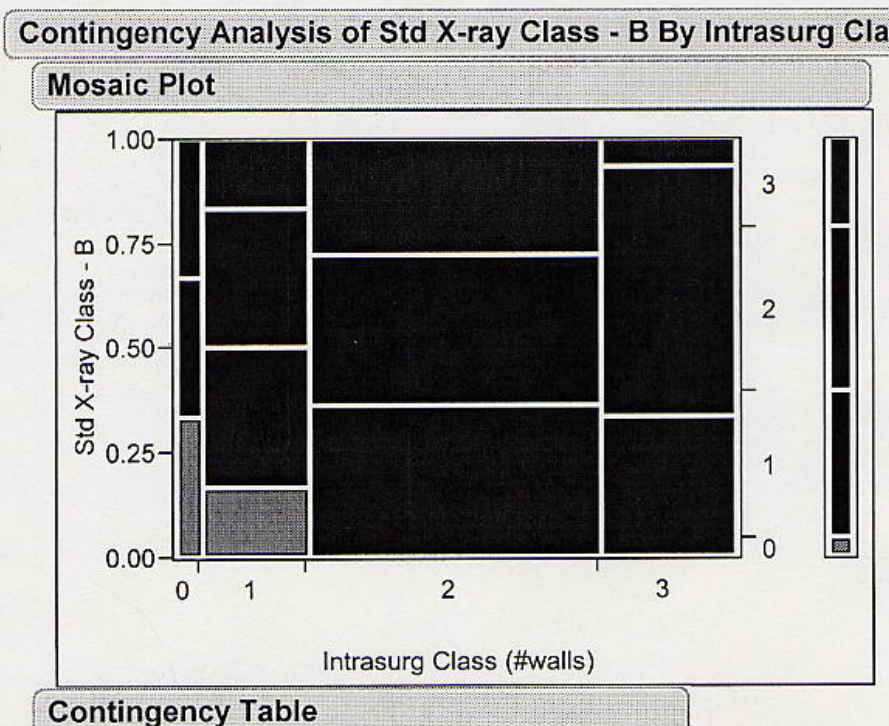

\begin{tabular}{|c|c|c|c|c|c|c|}
\hline & & & $\operatorname{tg} X$-ray & Class - & & \\
\hline & $\begin{array}{l}\text { Count } \\
\text { Total \% } \\
\text { Col \% } \\
\text { Row \% }\end{array}$ & 0 & 1 & 2 & 3 & \\
\hline & \begin{tabular}{l|l}
0 \\
\end{tabular} & & & o & 1 & \\
\hline & & 1.59 & 1.59 & 0.00 & 1.59 & 4.76 \\
\hline & & 33.33 & 4.55 & 0.00 & 7.69 & \\
\hline & & 33.33 & 33.33 & 0.00 & 33.33 & \\
\hline & 1 & 2 & 4 & 4 & 2 & 12 \\
\hline & & 3.17 & 6.35 & 6.35 & 3.17 & 19.05 \\
\hline & & 66.67 & 18.18 & 16.00 & 15.38 & \\
\hline & & 16.67 & 33.33 & 33.33 & 16.67 & \\
\hline & 2 & 0 & 12 & 12 & 9 & 33 \\
\hline & & 0.00 & 19.05 & 19.05 & 14.29 & 52.38 \\
\hline & & 0.00 & 54.55 & 48.00 & 69.23 & \\
\hline & & 0.00 & 36.36 & 36.36 & 27.27 & \\
\hline & 3 & & & 9 & & 15 \\
\hline & & 0.00 & 7.94 & 14.29 & 1.59 & 23.81 \\
\hline & & 0.00 & 22.73 & 36.00 & 7.69 & \\
\hline & & 0.00 & 33.33 & 60.00 & 6.67 & \\
\hline & & $\begin{array}{r}3 \\
476^{3}\end{array}$ & $\begin{array}{r}22 \\
3492\end{array}$ & $\begin{array}{r}25 \\
39.68\end{array}$ & $\begin{array}{r}13 \\
20.63\end{array}$ & 63 \\
\hline
\end{tabular}

\begin{tabular}{lrrr}
\hline Tests & & & \\
\hline Source & DF & -LogLike & RSquare (U) \\
Model & 9 & 7.880196 & 0.1038 \\
Error & 51 & 68.022284 & \\
C. Total & 60 & 75.902480 & \\
N & 63 & & \\
& & & \\
Test & ChiSquare & Prob $>$ ChiSq \\
Likelihood Ratio & 15.760 & 0.0721 \\
Pearson & & 16.455 & 0.0580
\end{tabular}

Warning: $20 \%$ of cells have expected count less than 5 , ChiSquare suspect

Warning: average cell count less than 5 , LR ChiSquare suspect

Kappa Std Err

$-0.059420 .078824$

Kappa measures the degree of agreement. 
defect01- Fit $Y$ by $X 3$

Contingency Analysis of Std X-ray Class - C By Intrasurg Class (\#walls) Mosaic Plot

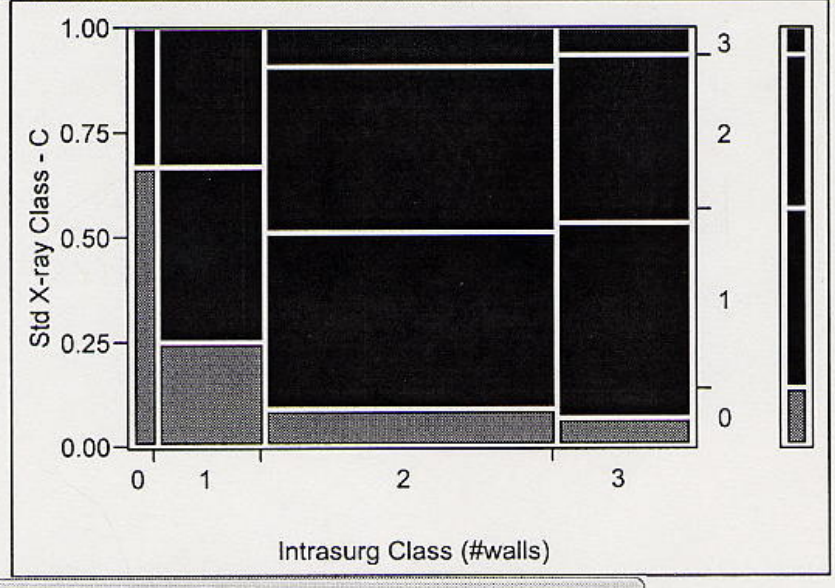

Contingency Table

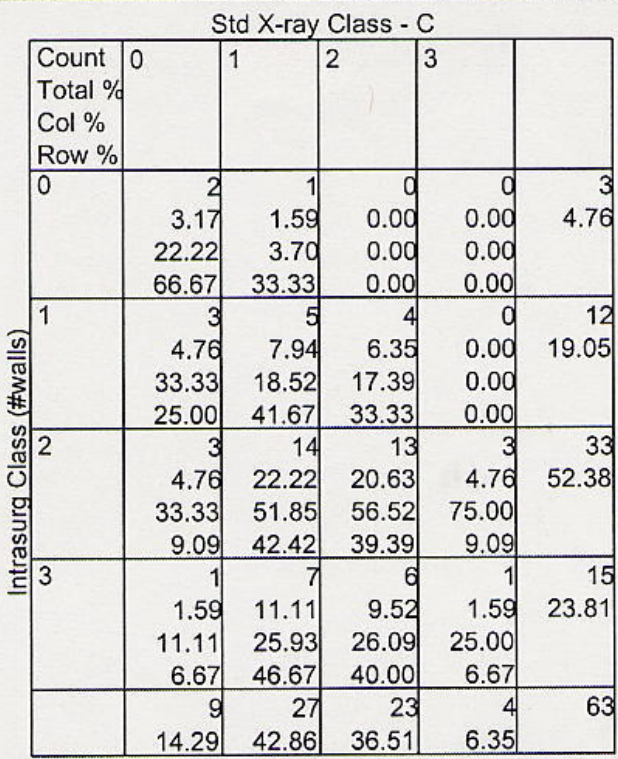

\section{Tests}

$\begin{array}{lrrr}\text { Source } & \text { DF } & \text {-LogLike } & \text { RSquare (U) } \\ \text { Model } & 9 & 5.002352 & 0.067 \\ \text { Error } & 51 & 69.590975 & \\ \text { C. Total } & 60 & 74.593327 & \\ \text { N } & 63 & & \\ & & & \\ \text { Test } & \text { ChiSquare } & \text { Prob }>\text { ChiSq } \\ \text { Likelihood Ratio } & 10.005 & 0.3501 \\ \text { Pearson } & & 10.678 & 0.2984\end{array}$

Warning: $20 \%$ of cells have expected count less than 5 , ChiSquare suspect

Warning: average cell count less than 5, LR ChiSquare suspect

Kappa Std Err

0.0546620 .075973

Kappa measures the degree of agreement. 
defect01- Fit $Y$ by $X 3$

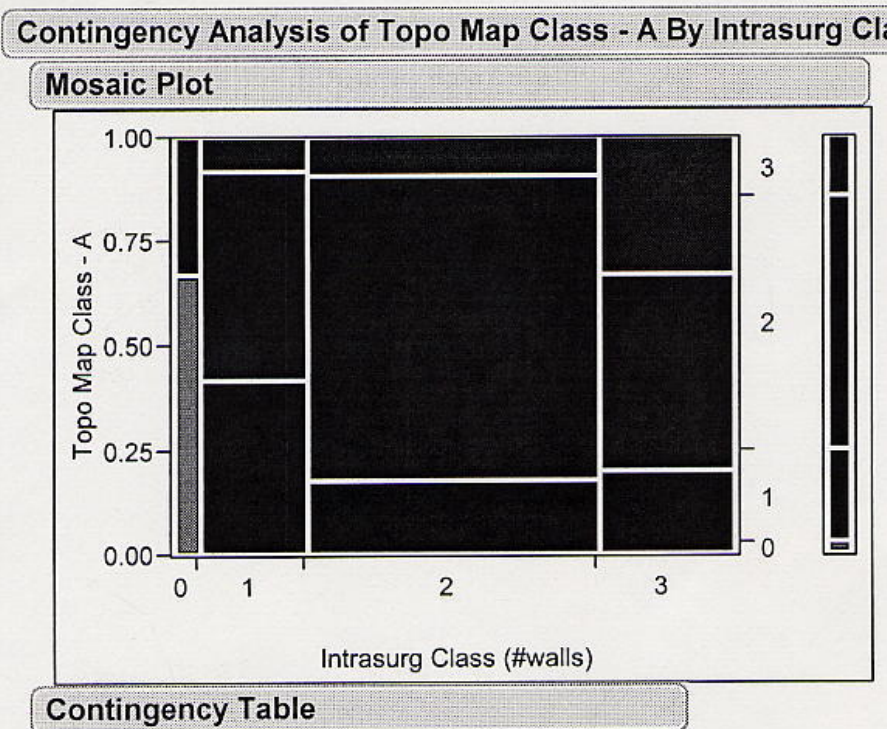

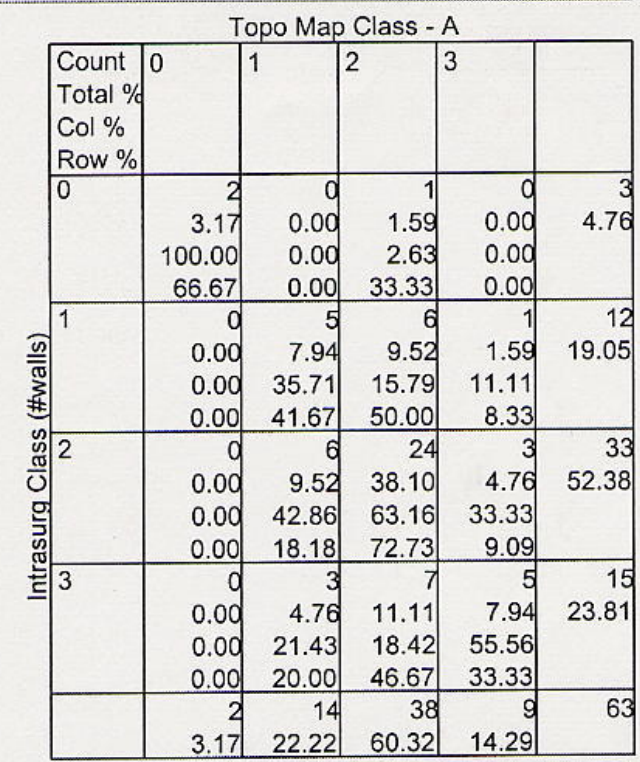

\begin{tabular}{lrrr}
\hline Tests & & & \\
\hline Source & DF & -LogLike & RSquare (U) \\
Model & 9 & 11.029000 & 0.170 \\
Error & 51 & 53.652095 & \\
C. Total & 60 & 64.681096 & \\
N & 63 & & \\
& & & \\
Test & ChiSquare & Prob $>$ ChiSq \\
Likelihood Ratio & 22.058 & 0.0087 \\
Pearson & & 50.023 & $<.0001$
\end{tabular}

Warning: $20 \%$ of cells have expected count less than 5 , ChiSquare suspect

Warning: average cell count less than 5 , LR ChiSquare suspect

Kappa Std Err

$0.293017 \quad 0.099839$

Kappa measures the degree of agreement. 
defect01- Fit $Y$ by $X 3$

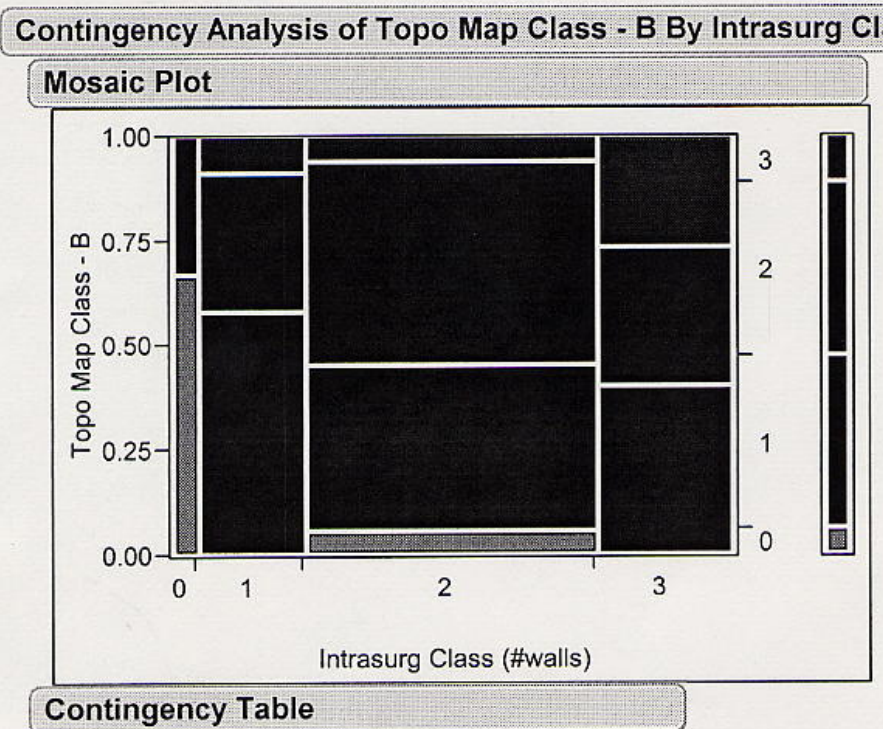

\begin{tabular}{|c|c|c|c|c|c|c|}
\hline & & & оро Мар & Class - & & \\
\hline & $\begin{array}{l}\text { Count } \\
\text { Total } \% \\
\text { Col } \% \\
\text { Row \% }\end{array}$ & 0 & 1 & \begin{tabular}{|l|l}
2 \\
\end{tabular} & 3 & \\
\hline & 要 & $\begin{array}{r}2 \\
3.17 \\
50.00 \\
66.67\end{array}$ & $\begin{array}{r}0 \\
0.00 \\
0.00 \\
0.00\end{array}$ & $\begin{array}{r}1 \\
1.59 \\
3.85 \\
33.33\end{array}$ & $\begin{array}{l}9 \\
0.00 \\
0.00 \\
0.00\end{array}$ & $\begin{array}{r}3 \\
4.76\end{array}$ \\
\hline & 1 & $\begin{array}{r}0 \\
0.00 \\
0.00 \\
0.00\end{array}$ & $\begin{array}{r}7 \\
11.11 \\
26.92 \\
58.33 \\
\end{array}$ & $\begin{array}{r}4 \\
6.35 \\
15.38 \\
33.33 \\
\end{array}$ & $\begin{array}{r}1 \\
1.59 \\
14.29 \\
8.33 \\
\end{array}$ & $\begin{array}{r}12 \\
19.05\end{array}$ \\
\hline & 2 & $\begin{array}{r}2 \\
3.17 \\
50.00 \\
6.06 \\
\end{array}$ & $\begin{array}{r}13 \\
20.63 \\
50.00 \\
39.39 \\
\end{array}$ & $\begin{array}{r}16 \\
25.40 \\
61.54 \\
48.48 \\
\end{array}$ & $\begin{array}{r}2 \\
3.17 \\
28.57 \\
6.06 \\
\end{array}$ & $\begin{array}{r}33 \\
52.38\end{array}$ \\
\hline & 3 & $\begin{array}{r}0 \\
0.00 \\
0.00 \\
0.00\end{array}$ & $\begin{array}{r}6 \\
9.52 \\
23.08 \\
40.00\end{array}$ & $\begin{array}{r}5 \\
7.94 \\
19.23 \\
33.33\end{array}$ & $\begin{array}{r}4 \\
6.35 \\
57.14 \\
26.67 \\
\end{array}$ & $\begin{array}{r}15 \\
23.81\end{array}$ \\
\hline & & & $\begin{array}{r}26 \\
41.27\end{array}$ & $\begin{array}{r}26 \\
41.27 \\
\end{array}$ & & 63 \\
\hline
\end{tabular}

\begin{tabular}{lrrr}
\hline Tests & & & \\
\hline Source & DF & -LogLike & RSquare (U) \\
Model & 9 & 8.683817 & 0.119 \\
Error & 51 & 63.746103 & \\
C. Total & 60 & 72.429919 & \\
N & 63 & & \\
& & & \\
Test & ChiSquare & Prob $>$ ChiSq \\
Likelihood Ratio & 17.368 & 0.0433 \\
Pearson & & 26.343 & 0.0018 \\
\hline
\end{tabular}

Warning: $20 \%$ of cells have expected count less than 5 , ChiSquare suspect

Warning: average cell count less than 5 , LR ChiSquare suspect

Kappa Std Err

0.2013420 .089808

Kappa measures the degree of agreement. 
defect01- Fit $Y$ by $X 3$

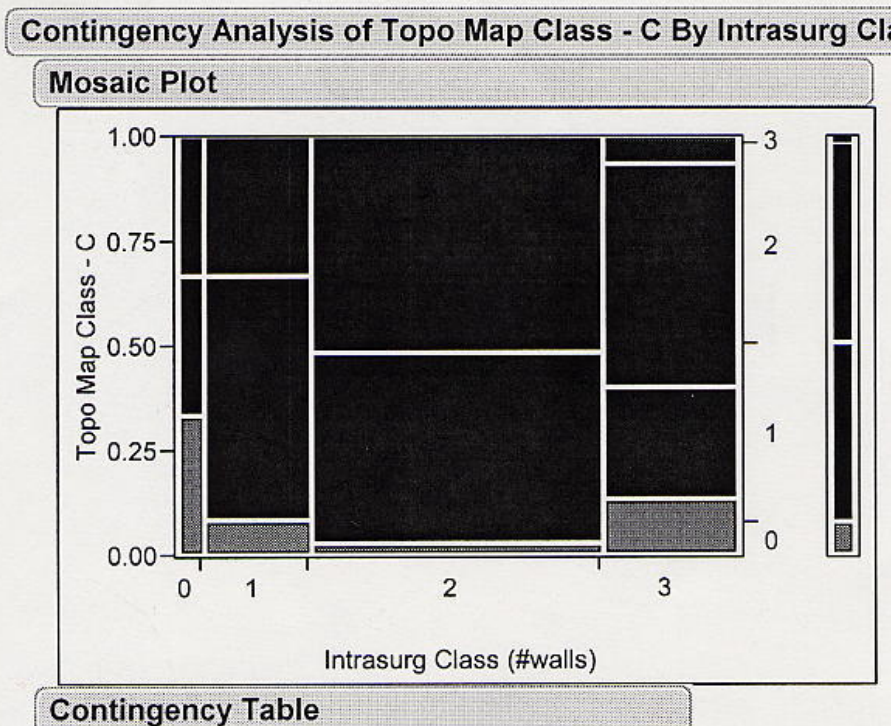

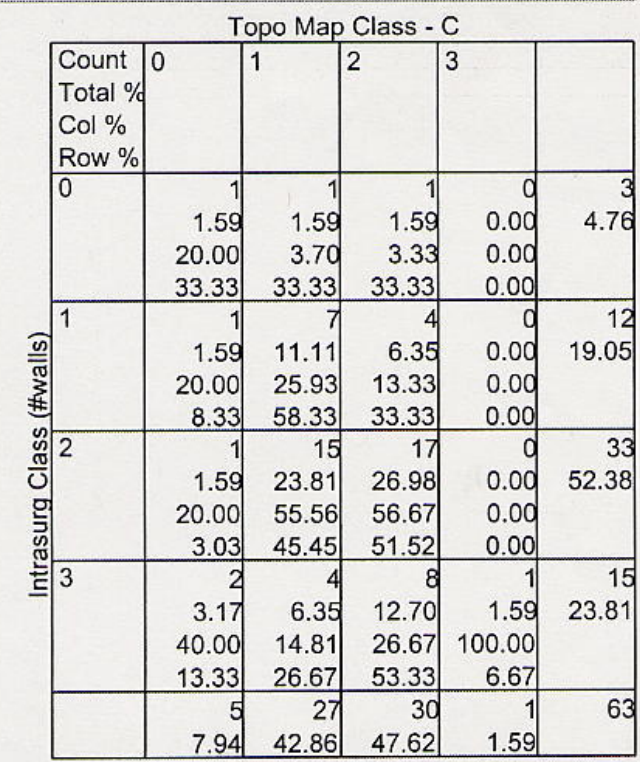

\begin{tabular}{lrrr}
\hline Tests & & & \\
\hline Source & DF & -LogLike & RSquare (U) \\
Model & 9 & 4.345495 & 0.070 \\
Error & 51 & 57.601287 & \\
C. Total & 60 & 61.946781 & \\
N & 63 & & \\
& & & \\
Test & ChiSquare & Prob $>$ ChiSq \\
Likelihood Ratio & 8.691 & 0.4663 \\
Pearson & & 9.746 & 0.3714 \\
\hline
\end{tabular}

Warning: $20 \%$ of cells have expected count less than 5 , ChiSquare suspect

Warning: average cell count less than 5, LR ChiSquare suspect

$$
\begin{array}{rr}
\text { Kappa } & \text { Std Err } \\
0.112 & 0.081782
\end{array}
$$

Kappa measures the degree of agreement. 


\section{CURRICULUM VITAE}

Name:

Date of Birth:

Place of Birth:

Education:

August 1996-June 1999

August 1999-May 2003

July 2003-Present

Professional Memberships:

August 1999-May 2003

May 2003-Present

May 2003-Present

July 2003-Present
Michael Anthony Hazey, III

January 20, 1978

Clarksburg, West Virginia

The Pennsylvania State University

University Park, Pennsylvania

Bachelor of Science, Premedicine

Graduated with High Distinction

West Virginia University School of Dentistry

Morgantown, West Virginia

Doctorate of Dental Surgery

West Virginia University School of Dentistry

Department of Orthodontics

Morgantown, West Virginia

Master of Science (anticipated May 2006)

American Student Dental Association

American Dental Association

Omicron Kappa Upsilon-Honorary Dental

Fraternity

American Association of Orthodontists 